\title{
Assessment of Smolt Condition for Travel Time Analysis
}

\section{Annual Report 1993-1994}

\author{
U. S. Department of the Interior \\ U. S. Geological Survey \\ Biological Resources Division
}

Columbia River Research Laboratory

U. S. Department of Energy

Bonneville Power Administration

Division of Fish and Wildlife

February 1999 


\title{
Assessment of Smolt Condition for Travel Time Analysis
}

\section{Annual Report 1993-1994}

\author{
Prepared By \\ Robin M. Schrock \\ Philip V. Haner \\ Karen M. Hans \\ John W. Beeman \\ Scott P. VanderKooi \\ Jack D. Hotchkiss \\ Pamela A. Petrusso \\ Stanley G. Smith \\ Alec G. Maule \\ U. S. Geological Survey \\ Biological Resources Division \\ Columbia River Research Laboratory \\ 5501A Cook-Underwood Rd. \\ Cook, Washington 98605 \\ Prepared For \\ U. S. Department of Energy \\ Bonneville Power Administration \\ Division of Fish and Wildlife \\ P.O. Box 3621 \\ Portland, Oregon 97028 \\ Project No. 87-401 \\ Contract No. DE-A179-87BP35245
}

February 1999 


\begin{abstract}
The Assessment of Smolt Condition for Travel Time Analysis (ASCTTA) project provided information on the level of smoltification in Columbia River hatchery and wild salmonid stocks to the Fish Passage Center (FPC), for the primary purpose of in-river management of flows. The objective of the project was to evaluate smoltification of index hatchery release groups at traps on tributaries and at dams. A non-lethal microassay for gill sodium, potassium ATPase developed by the project was incorporated into the assessment program, and health monitoring for the severity of bacterial kidney disease (BKD) of index fish stocks continued as in previous years.

Changes in management approaches in the basin were reflected in modifications of ASCTTA project objectives in 1993 and 1994, including: 1) use of additional reference stocks for monitoring and evaluation, at the request of regional fish managers; 2) changes in marking methods and technology, with a shift from freeze-branded groups to passive integrated transponder (PIT)-tagged individuals; and 3) monitoring of the migration with species groups in the run-at-large rather than individual stocks.

Seasonal patterns of smolt development in wild and hatchery salmonids were evaluated and compared. Intensive sampling of single hatchery stocks of known origin was replaced by a greater interest in the total migration and identification of specific migration reaches where mortality occurred. In this capacity, the project participated in the Lower Granite Survival Study in cooperation with the National Marine Fisheries Service. Further cooperation and technical assistance was provided to the U. S. Fish and Wildlife Service (USFWS), Idaho Fishery Resource Office and Dworshak National Fish Hatchery, to study the effects of release time on juvenile migration performance and adult returns.

Travel time analysis for the two-year period was delayed by the absence of specific marked reference groups for the determination of migration rates through specific reaches. Although measures of smoltification were made on PIT-tagged individuals and run-at-large fish, several years of data were considered necessary to accommodate the change in the marking program and the large differences in flows and temperatures seen between 1993 and 1994.

Results of run-at-large comparisons between years showed that differences in ATPase levels were marked at different flows and temperatures. Comparisons of fish collected from Lower Granite Reservoir to fish collected at Lower Granite Dam and Little Goose Dam suggested that collection, sampling and release was more stressful at dams than in the reservoir. Mucus lysozyme analysis, investigated as a potential method of determining the level of smoltification, provided the first reference mucus lysozyme levels for the index stocks.
\end{abstract}




\section{EXECUTIVE SUMMARY}

The physiological assessment of juvenile salmonid migrants, summarized in weekly reports to the Fish Passage Center for use in Water Budget management, remained the primary activity of the Assessment of Smolt Condition for Travel Time Analysis (ASCTTA) project during 1993 and 1994. The Water Budget is a procedure for implementing flow augmentation and reservoir operations measures to assist juvenile salmonid downstream emigration. The Water Budget is implemented through a Coordinated Plan of Operation (CPO) developed by the U.S. Army Corps of Engineers (COE) in cooperation with the Northwest Power Planning Council (NWPPC), Fish Passage Center (FPC), Bonneville Power Administration (BPA), U.S. Bureau of Reclamation (USBR), fishery agencies, Indian tribes, utility companies, and others. The FPC makes CPO requests based upon water supply forecasts and actual smolt passage indices in order to mitigate the effect of decreasing flows on juvenile downstream passage. The FPC uses historical and realtime data including mark/recaptures, passage indices, fish condition, flows and flow forecasts, dissolved gas saturation, water temperature, spill, and hatchery release information to determine the extent of CPO requests. In 1993 and 1994, the ASCTTA project provided weekly reports to the FPC on condition factor (Kfactor) and gill $\mathrm{Na}^{+}, \mathrm{K}^{+}$-ATPase from run-at-large yearling spring/summer chinook salmon (Oncorhynchus tshawytscha), subyearling fall chinook salmon, and steelhead (O. mykiss). The ASCTTA data were among the information used by the FPC to determine flow augmentation requests to $\mathrm{COE}$ and private utilities that operate dams on the Columbia and Snake rivers.

Monitoring of the physiological condition of Columbia River basin juvenile salmonids, including chinook salmon, steelhead, and sockeye salmon (O. nerka), was conducted during rearing and the annual juvenile migration in the Snake and Columbia rivers. This report provides physiological data for the seventh and eighth years of the project. Changes in the monitoring program included incorporation of data from wild spring chinook salmon and steelhead from the run-at-large, sampling at traps on tributaries of the Columbia River, and evaluations of subyearling chinook salmon and sockeye salmon at Rock Island Dam. The use of passive integrated transponder (PIT)-tagged individuals rather than freeze-branded hatchery groups for travel time analysis allowed us to assess the performance of both wild and hatchery fish as individuals. The change in how fish were marked for identification for monitoring purposes forestalled annual travel time analysis. In addition, large differences between flows and temperatures in 1993 and 1994 precluded this analysis until a multi-year database was available. A preliminary review of this data was included in the ASCTTA ten-year project review completed in 1998.

Biological monitoring methods developed by the project were applied to monitoring goals, and the results appeared in publications as peer-reviewed articles. The introduction of a new nonlethal method for gill ATPase analysis allowed release of all sampled fish, enabling them to continue migrating. Because it was no longer necessary to sacrifice fish for ATPase analysis, kidneys were no longer collected during the migration to determine the severity and prevalence of bacterial kidney disease (BKD), although BKD screening continued for spring chinook salmon at Snake and mid-Columbia River hatcheries. Mucus lysozyme was determined in Columbia basin salmonid stocks to determine if lysozyme measurements could be applied as an index of smolt development. Similar patterns of change in mucus lysozyme concentrations in different stocks 
during juvenile salmonid development suggest that stock reference levels may exist that could be used to distinguish different levels of smolt development.

The recognition by regional managers and agencies of the importance of physiological monitoring as an evaluative tool for assessing fish performance under different rearing, release, migration, or passage conditions was evidenced by increased project participation in technical assistance activities. We provided physiological monitoring assistance to index hatcheries, and to an Army Corps of Engineers (COE)-funded release study at Dworshak National Fish Hatchery, in cooperation with the U. S. Fish and Wildlife Service Idaho Fishery Resource Office. Assistance was also provided to a National Marine Fisheries Service study on survival of juvenile salmonids passing through dams and reservoirs. 


\section{ACKNOWLEDGEMENTS}

We thank the Bonneville Power Administration, Fish Passage Center, U. S. Fish and Wildlife Service, National Marine Fisheries Service, U. S. Army Corps of Engineers, Idaho Department of Fish and Game, Oregon Department of Fish and Wildlife, Washington Department of Fish and Wildlife, the Smolt Monitoring Program of the Chelan County Public Utility District, and the Nez Perce Tribe. The cooperation of managers and staff of federal and state hatcheries in the Columbia and Snake River basins was instrumental to the project. We are also grateful to the staff of the Columbia River Research Laboratory for their efforts. 


\section{DISCLAIMER}

Although these data have been processed successfully on a computer system at the U.S. Geological Survey, Columbia River Research Laboratory, no warranty, expressed or implied, is made regarding the accuracy or utility of the data on any other system or for general or scientific purposes, nor shall the act of distribution constitute any such warranty. This disclaimer applies to both individual use of the data and aggregate use with other data. It is strongly recommended that these data be acquired directly from a U.S. Geological Survey server and not indirectly through other sources which may have changed the data in some way. It is also strongly recommended that careful attention be paid to the contents of the metadata files associated with these data. The U.S. Geological Survey shall not be held liable for improper or incorrect use of the data described and/or contained herein.

Mention of trade names or commercial products does not constitute endorsement or recommendation for use by the U.S. Geological Survey, U.S. Department of the Interior.

If you have any questions or comments concerning this data product, please contact Robin Schrock at (509) 538-2299 ext. 231. 


\section{TABLE OF CONTENTS}

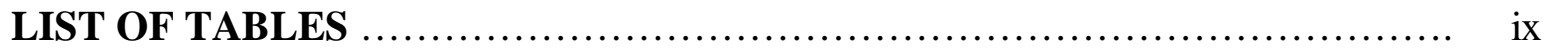

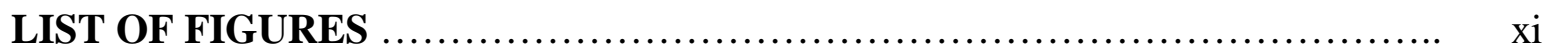

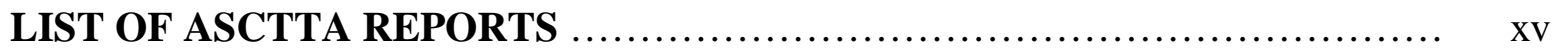

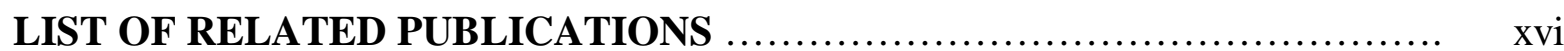

CHAPTER ONE: Profiles of Gill Sodium, Potassium-Activated ATPase as an Index of Smoltification in Hatchery and Wild Salmonids .............................. 1

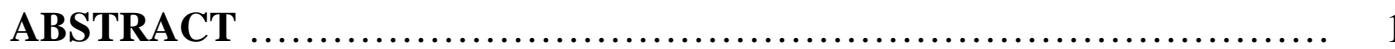

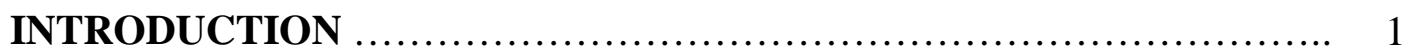

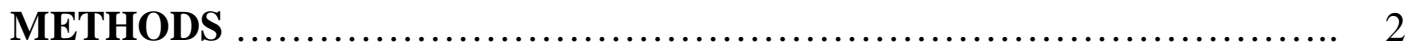

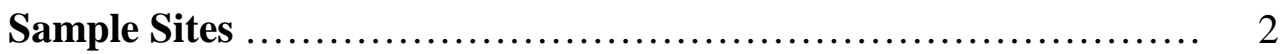

Hatcheries ............................................ 2

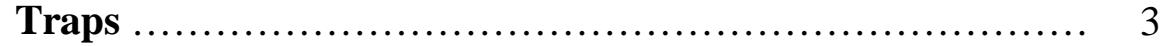

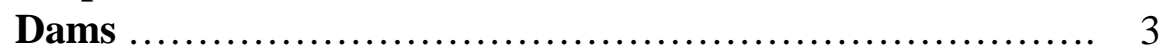

Sample Sizes ............................................. 3

Tissue Collection and Analysis $\ldots \ldots \ldots \ldots \ldots \ldots \ldots \ldots \ldots \ldots \ldots \ldots \ldots, 3$

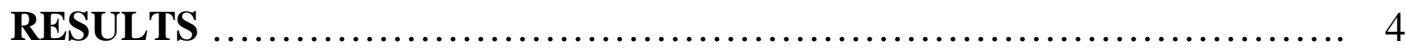

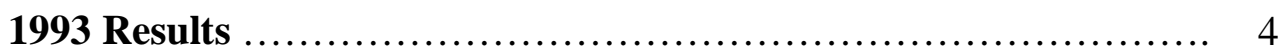

Yearling Chinook Salmon .............................. 4

Hatcheries ............................................ 4

Traps ................................................ 4

Snake River Dams ................................ 5

Columbia River Dams ............................... 5

Subyearling Chinook Salmon ............................. 5

Hatcheries ...................................... 5

Columbia River Dams .............................. 5

Steelhead ............................................... 6

Hatcheries ......................................... 6

Traps ............................................. 6

Snake River Dams .................................. 6

Columbia River Dams ................................. 6

Sockeye Salmon ........................................ 7

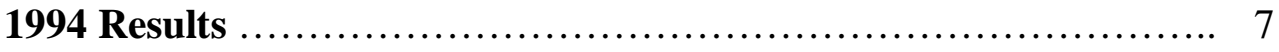

Yearling Chinook Salmon .............................. 7

Hatcheries ........................................ 7

Traps ........................................... 7

Snake River Dams .................................. 8

Columbia River Dams .................................. 8 
Subyearling Chinook Salmon ............................. 8

Hatcheries ........................................... 8

Columbia River Dams .................................... 8

Steelhead ....................................................... 9

Hatcheries ............................................... 9

Traps ................................................... 9

Snake River Dams ........................................ 9

Columbia River Dams .................................... 9

Sockeye Salmon .............................................. 10

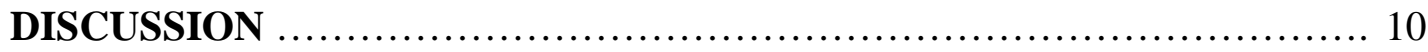

CHAPTER ONE FIGURES ............................................ 15

CHAPTER TWO: Physiological Measurements in Support of Survival Estimates of Juvenile Salmonids Passing through Dams and Reservoirs ...................... 38

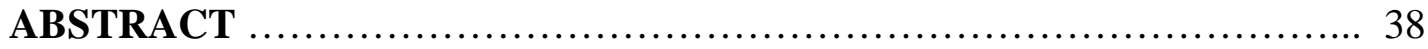

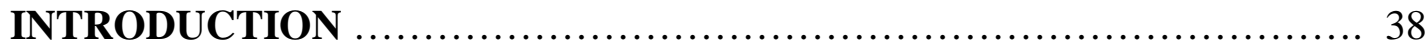

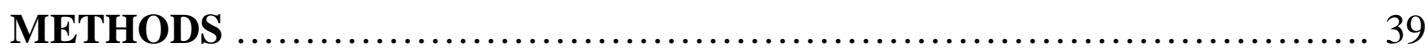

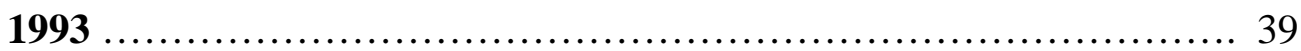

Reservoir Sampling ......................................... 39

Dam Sampling ............................................ 39

Statistical Analysis ...................................... 40

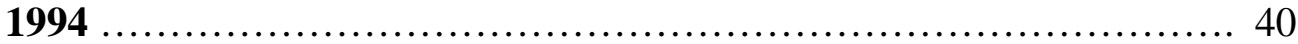

Reservoir Sampling .................................... 40

Dam Sampling .......................................... 40

Statistical Analysis ....................................... 40

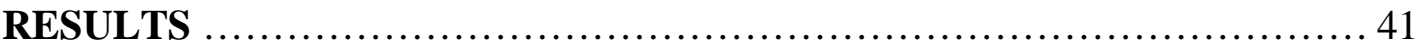

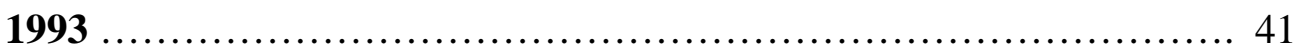

$\mathrm{Gill} \mathrm{Na}^{+}, \mathrm{K}^{+}$-ATPase Activity ............................ 41

Condition Factor ........................................ 41

Plasma Cortisol ........................................... 41

Bacterial Kidney Disease ................................. 41

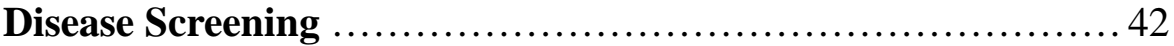

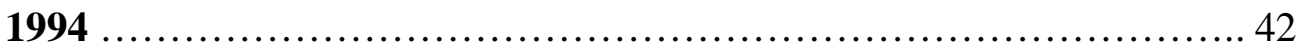

$\mathrm{Gill} \mathrm{Na}^{+}, \mathrm{K}^{+}$-ATPase Activity ............................. 42

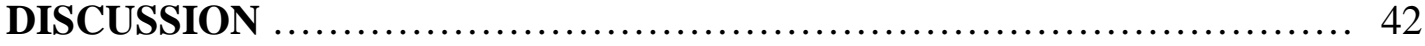

CHAPTER TWO TABLES .............................................. 44

CHAPTER THREE: Mucus Lysozyme as a Non-Lethal Measure of Health in Pacific

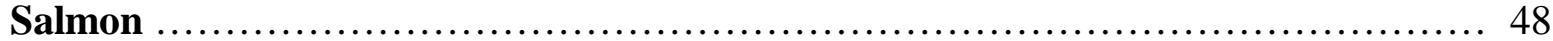

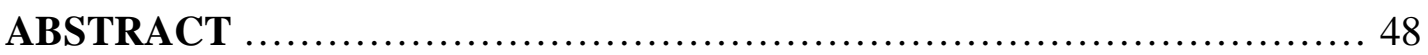

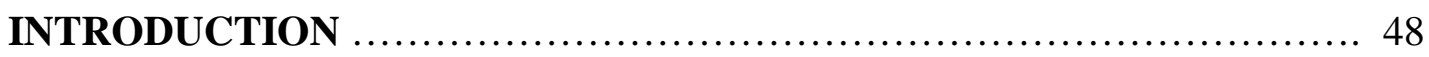

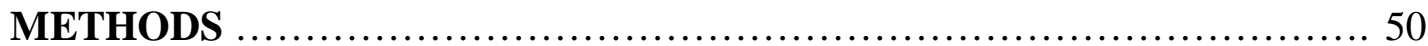

Fish Collection Procedures ...................................... 50

Baseline Levels in Hatchery Reference Stocks .................... 50 
Experimental Fish from Covered and Uncovered Hatchery

Raceways ........................................ 51

Disease Challenge Experiments ........................... 51

Lysozyme Sample Collection ................................. 52

Lysozyme Analysis .......................................... 53

Statistical Analysis .............................................. 53

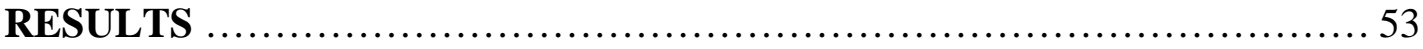

Baseline Levels in Hatchery Reference Stocks ..................... 53

Hatchery Release Groups ..................................... 53

Adult Salmon .................................................. 53

Experimental Fish from Covered and Uncovered Hatchery Raceways 54

Disease Challenge Experiments ................................. 55

1993 Results ............................................. 55

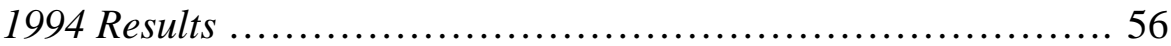

DISCUSSION ........................................................ 56

Baseline Levels in Hatchery Reference Stocks .................... 57

Juvenile Salmon ........................................ 57

Adult Salmon ................................................ 58

Experimental Fish from Covered and Uncovered Hatchery Raceways 58

Disease Challenge Experiments .............................. 58

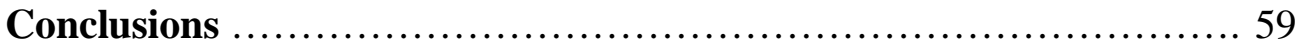

CHAPTER THREE TABLES ........................................... 61

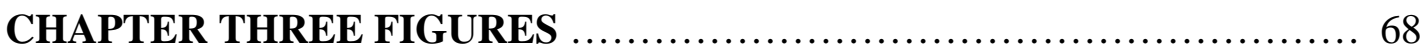

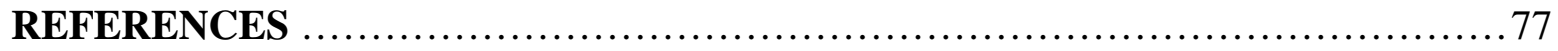

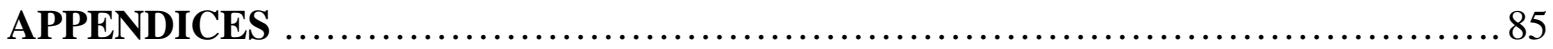




\section{LIST OF TABLES}

\section{CHAPTER TWO:}

Table 1. Mean $( \pm \mathrm{SE})$ gill $\mathrm{Na}^{+}, \mathrm{K}^{+}$-ATPase, condition factor (Kfactor), and plasma cortisol of hatchery spring chinook salmon sampled during the Lower Granite Survival Study in 1993. Data are arranged by releases within a site and by site. Mean values with letters in common differ significantly from others within that group based on an F-test of differences between releases within a site, or between sites $(P \leq 0.05)$ (LRS = Lower Granite Reservoir; LGR = Lower Granite Dam; LGS = Little Goose Dam)

Table 2. Presence of bacterial kidney disease as percent positive (\%Pos) and sample sizes of hatchery spring chinook salmon sampled during the Lower Granite Survival Study in 1993. A chi-squared test was used to determine significant differences $(P \leq 0.05)$ between releases from a release site, or between release sites (LRS $=$ Lower Granite Reservoir; LGR $=$ Lower Granite Dam; LGS = Little Goose Dam) 46

Table 3. Mean ( \pm SE) gill $\mathrm{Na}^{+}, \mathrm{K}^{+}$-ATPase in hatchery spring chinook salmon (HSPC) and hatchery steelhead (HSTH) sampled during the Lower Granite Survival Study in 1994. Mean values with letters in common differ significantly from others within that group based on an F-test of differences between releases within a site, or between sites $(P \leq 0.05)$ (LRS $=$ Lower Granite Reservoir; LGR = Lower Granite Dam; LGS = Little Goose Dam; LMN = Lower Monumental Dam)

\section{CHAPTER THREE:}

Table 1. Mean $( \pm \mathrm{SE})$ nare mucus lysozyme concentration $\left(\mu \mathrm{g} \cdot \mathrm{mL}^{-1}\right)$, release date, and sample size $(N)$ of juvenile chinook salmon released from Columbia and Snake River basin hatcheries in 1994. Means with the same letter differ significantly $(P \leq 0.05)$ ( $\mathrm{SPCH}=$ spring chinook salmon; $\mathrm{SUCH}=$ summer chinook salmon; NFH = National Fish Hatchery; SFH = State Fish Hatchery)

Table 2. Mean $( \pm \mathrm{SE})$ plasma and secondary circulation lysozyme concentrations in adult chinook salmon returning to Carson National Fish Hatchery in $1993(N=$ sample size $)$. Means with the same letter differ significantly $(P \leq 0.05)$

Table 3. Mean $( \pm \mathrm{SE})$ serum, secondary circulation, skin mucus, and vent mucus lysozyme concentrations in adult chinook salmon returning to Carson National Fish Hatchery in $1994(N=$ sample size). Means with the same letter differ significantly $(P \leq 0.05) \ldots \ldots \ldots \ldots \ldots \ldots .64$ 
Table 4. Mean $( \pm \mathrm{SE})$ serum, secondary circulation, and skin mucus lysozyme concentrations in adult chinook salmon returning to Little White Salmon National Fish Hatchery in $1994(N=$ sample size)

Table 5. Mean $( \pm \mathrm{SE})$ skin, nare, and vent mucus lysozyme concentrations in juvenile coho salmon used in raceway cover experiments at Willard National Fish Hatchery, 1993-1994 ( $N=$ sample size). Means with the same letter differ significantly $(P \leq 0.05) \ldots \ldots \ldots \ldots \ldots \ldots 66$

Table 6. Mean $( \pm \mathrm{SE})$ skin, nare and vent mucus lysozyme concentrations in juvenile spring chinook salmon used in raceway cover experiments at Little White Salmon National Fish Hatchery, 1993-1994 $(N=$ sample size $)$. Means with the same letter differ significantly $(P \leq$ 


\section{LIST OF FIGURES}

\section{CHAPTER ONE:}

Figure 1. Mean $( \pm \mathrm{SE})$ gill $\mathrm{Na}^{+}, \mathrm{K}^{+}$-ATPase activity $\left(\mu \mathrm{mol} \mathrm{P}_{\mathrm{i}} \cdot \mathrm{mg}\right.$ protein $\left.{ }^{-1} \cdot \mathrm{h}^{-1}\right)$ for yearling spring/summer chinook salmon sampled before release in 1993 from (a) Snake River basin hatcheries, and (b) Columbia River basin hatcheries; (c) subyearling chinook salmon before release at Priest Rapids and Turtle Rock State Fish Hatcheries (SFH); and (d) steelhead sampled before release at Dworshak National Fish Hatchery (NFH) and Irrigon SFH. Data are listed in

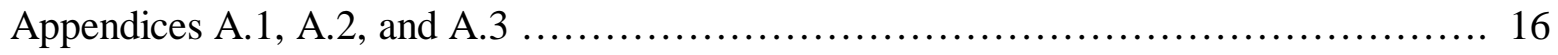

Figure 2. Mean $( \pm \mathrm{SE})$ gill $\mathrm{Na}^{+}, \mathrm{K}^{+}$-ATPase activity $\left(\mu \mathrm{mol} \mathrm{P}_{\mathrm{i}} \cdot \mathrm{mg}\right.$ protein $\left.{ }^{-1} \cdot \mathrm{h}^{-1}\right)$ of wild and hatchery yearling chinook salmon collected during migration in 1993 at (a) the Clearwater River Trap, (b) the Salmon River Trap, and (c) the Snake River Trap. Data are listed in Appendices B. 1 and $\mathrm{C}$ 17

Figure 3. Mean $( \pm \mathrm{SE})$ gill $\mathrm{Na}^{+}, \mathrm{K}^{+}$-ATPase activity $\left(\mu \mathrm{mol} \mathrm{P}_{\mathrm{i}} \cdot \mathrm{mg}\right.$ protein $\left.{ }^{-1} \cdot \mathrm{h}^{-1}\right)$ of wild and hatchery yearling chinook salmon collected during migration in 1993 at (a) Lower Granite Dam and (b) Little Goose Dam on the Snake River. Data are listed in Appendices B.1 and C .. 18

Figure 4. Mean $( \pm \mathrm{SE})$ gill $\mathrm{Na}^{+}, \mathrm{K}^{+}$-ATPase activity $\left(\mu \mathrm{mol} \mathrm{P}_{\mathrm{i}} \cdot \mathrm{mg} \operatorname{protein}^{-1} \cdot \mathrm{h}^{-1}\right)$ of yearling chinook salmon with intact adipose fins and yearling hatchery chinook salmon (adipose finclipped) collected during migration in 1993 at (a) Rock Island Dam and (b) McNary Dam on the Columbia River. Data are listed in Appendix B.2

Figure 5. Mean $( \pm \mathrm{SE})$ gill $\mathrm{Na}^{+}, \mathrm{K}^{+}$-ATPase activity $\left(\mu \mathrm{mol} \mathrm{P}_{\mathrm{i}} \cdot \mathrm{mg}_{\text {protein }}{ }^{-1} \cdot \mathrm{h}^{-1}\right)$ of subyearling fall chinook salmon collected during migration in 1993 at (a) Rock Island Dam, (b) McNary Dam, and (c) John Day Dam and Bonneville Dam, on the Columbia River. Data are listed in Appendix D

Figure 6. Mean $( \pm \mathrm{SE})$ gill $\mathrm{Na}^{+}, \mathrm{K}^{+}$-ATPase activity $\left(\mu \mathrm{mol} \mathrm{P}_{\mathrm{i}} \cdot \mathrm{mg}\right.$ protein $\left.{ }^{-1} \cdot \mathrm{h}^{-1}\right)$ of wild and hatchery steelhead collected during migration in 1993 at (a) the Salmon River Trap and (b) the Snake River Trap. Data are listed in Appendices E and F

Figure 7. Mean $( \pm \mathrm{SE})$ gill $\mathrm{Na}^{+}, \mathrm{K}^{+}$-ATPase activity $\left(\mu \mathrm{mol} \mathrm{P}_{\mathrm{i}} \cdot \mathrm{mg}\right.$ protein $\left.{ }^{-1} \cdot \mathrm{h}^{-1}\right)$ of wild and hatchery steelhead collected during migration in 1993 at (a) Lower Granite Dam, and (b) Little Goose Dam on the Snake River. Data are listed in Appendices E and F 22

Figure 8. Mean $( \pm \mathrm{SE})$ gill $\mathrm{Na}^{+}, \mathrm{K}^{+}$-ATPase activity $\left(\mu \mathrm{mol} \mathrm{P}_{\mathrm{i}} \cdot \mathrm{mg}\right.$ protein $\left.{ }^{-1} \cdot \mathrm{h}^{-1}\right)$ of wild and hatchery steelhead collected during migration in 1993 at (a) Rock Island Dam and (b) McNary Dam on the Columbia River. Data are listed in Appendices E and F 23 
Figure 9. Mean $( \pm \mathrm{SE})$ gill $\mathrm{Na}^{+}, \mathrm{K}^{+}$-ATPase activity $\left(\mu \mathrm{mol} \mathrm{P}_{\mathrm{i}} \cdot \mathrm{mg}\right.$ protein $\left.{ }^{-1} \cdot \mathrm{h}^{-1}\right)$ of wild and hatchery sockeye salmon collected during migration in 1993 at Rock Island Dam on the Columbia River. Data are listed in Appendices G.1 and G.2

Figure 10. Mean $( \pm \mathrm{SE})$ gill $\mathrm{Na}^{+}, \mathrm{K}^{+}$-ATPase activity $\left(\mu \mathrm{mol} \mathrm{P}_{\mathrm{i}} \cdot \operatorname{mg}\right.$ protein $\left.{ }^{-1} \cdot \mathrm{h}^{-1}\right)$ of yearling spring chinook salmon sampled before release in 1994 from (a) Dworshak National Fish Hatchery (NFH), (b) Columbia River basin hatcheries, and (c) Snake River basin hatcheries.

Data are listed in Appendix H.1 25

Figure 11. Mean $( \pm \mathrm{SE})$ gill $\mathrm{Na}^{+}, \mathrm{K}^{+}$-ATPase activity $\left(\mu \mathrm{mol} \mathrm{P}_{\mathrm{i}} \cdot \mathrm{mg}\right.$ protein $\left.{ }^{-1} \cdot \mathrm{h}^{-1}\right)$ of wild and hatchery yearling chinook salmon collected during migration in 1994 at (a) the Clearwater River Trap, (b) the Salmon River Trap, and (c) the Snake River Trap. Data are listed in Appendices I.1 and $\mathbf{J}$ 26

Figure 12. Mean $\left( \pm\right.$ SE) gill $\mathrm{Na}^{+}, \mathrm{K}^{+}$-ATPase activity $\left(\mu \mathrm{mol} \mathrm{P}_{\mathrm{i}} \cdot \mathrm{mg} \operatorname{protein}^{-1} \cdot \mathrm{h}^{-1}\right)$ of wild and hatchery yearling chinook salmon collected during migration in 1994 at (a) the Imnaha River Trap and (b) the Grande Ronde River Trap. Data are listed in Appendices I.1 and J ...... 27

Figure 13. Mean $( \pm \mathrm{SE})$ gill $\mathrm{Na}^{+}, \mathrm{K}^{+}$-ATPase activity $\left(\mu \mathrm{mol} \mathrm{P}_{\mathrm{i}} \cdot \mathrm{mg}\right.$ protein $\left.{ }^{-1} \cdot \mathrm{h}^{-1}\right)$ of wild and hatchery yearling chinook salmon collected during migration in 1994 at Lower Granite Dam on the Snake River. Data are listed in Appendices I.1 and J ....................... 28

Figure 14. Mean $( \pm \mathrm{SE})$ gill $\mathrm{Na}^{+}, \mathrm{K}^{+}$-ATPase activity $\left(\mu \mathrm{mol} \mathrm{P}_{\mathrm{i}} \cdot \mathrm{mg}\right.$ protein $\left.{ }^{-1} \cdot \mathrm{h}^{-1}\right)$ of yearling chinook salmon with intact adipose fins and hatchery yearling chinook salmon (adipose finclipped) collected during migration in 1994 at (a) Rock Island Dam and (b) McNary Dam on the Columbia River. Data are listed in Appendices I.1 and I.2 .......................... 29

Figure 15. Mean $( \pm \mathrm{SE})$ gill $\mathrm{Na}^{+}, \mathrm{K}^{+}$-ATPase activity $\left(\mu \mathrm{mol} \mathrm{P}_{\mathrm{i}} \cdot \mathrm{mg}\right.$ protein $\left.{ }^{-1} \cdot \mathrm{h}^{-1}\right)$ of subyearling fall chinook salmon collected during migration in 1994 at (a) Rock Island Dam, (b) McNary Dam, and (c) John Day Dam on the Columbia River. Data are listed in Appendix K ..... 30

Figure 16. Mean $( \pm \mathrm{SE})$ gill $\mathrm{Na}^{+}, \mathrm{K}^{+}$-ATPase activity $\left(\mu \mathrm{mol} \mathrm{P}_{\mathrm{i}} \cdot \mathrm{mg}\right.$ protein $\left.{ }^{-1} \cdot \mathrm{h}^{-1}\right)$ of wild and hatchery steelhead collected during migration in 1994 at (a) Snake River Trap and (b) Salmon River Trap. Data are listed in Appendices L and M 31

Figure 17. Mean $\left( \pm\right.$ SE) gill $\mathrm{Na}^{+}, \mathrm{K}^{+}$-ATPase activity $\left(\mu \mathrm{mol} \mathrm{P}_{\mathrm{i}} \cdot \operatorname{mg}\right.$ protein $\left.{ }^{-1} \cdot \mathrm{h}^{-1}\right)$ of wild and hatchery steelhead collected during migration in 1994 at (a) the Imnaha River Trap and (b) the Grande Ronde River Trap. Data are listed in Appendices L and M 32

Figure 18. Mean $( \pm \mathrm{SE})$ gill $\mathrm{Na}^{+}, \mathrm{K}^{+}$-ATPase activity $\left(\mu \mathrm{mol} \mathrm{P}_{\mathrm{i}} \cdot \operatorname{mg}\right.$ protein $\left.{ }^{-1} \cdot \mathrm{h}^{-1}\right)$ of wild and hatchery steelhead collected during migration in 1994 at Lower Granite Dam on the Snake River. Data are listed in Appendices L and M 33 
Figure 19. Mean $( \pm \mathrm{SE})$ gill $\mathrm{Na}^{+}, \mathrm{K}^{+}$-ATPase activity $\left(\mu \mathrm{mol} \mathrm{P}_{\mathrm{i}} \cdot \operatorname{mg} \operatorname{protein}^{-1} \cdot \mathrm{h}^{-1}\right)$ of wild and hatchery steelhead collected during migration in 1994 at (a) Rock Island Dam and (b) McNary Dam on the Columbia River. Data are listed in Appendices L and M

Figure 20. Mean $( \pm \mathrm{SE})$ gill $\mathrm{Na}^{+}, \mathrm{K}^{+}$-ATPase activity $\left(\mu \mathrm{mol} \mathrm{P}_{\mathrm{i}} \cdot \mathrm{mg}\right.$ protein $\left.{ }^{-1} \cdot \mathrm{h}^{-1}\right)$ of wild and hatchery sockeye salmon collected during migration in 1994 at Rock Island Dam on the Columbia River. Data are listed in Appendices N.1 and N.2 ….................. 35

Figure 21. Columbia River flow (kcfs) at Rock Island Dam, April-October, 1987-1994 (Source: U.S. Army Corps of Engineers data, University of Washington 1998) ................. 36

Figure 22. Columbia River flow (kcfs) at McNary Dam, April-October, 1987-1994 (Source: U.S. Army Corps of Engineers data, University of Washington 1998) ...................36

Figure 23. Columbia River temperature $\left({ }^{\circ} \mathrm{C}\right)$ at McNary Dam, April-October, 1987-1994 (Source: U.S. Army Corps of Engineers data, University of Washington 1998) 37

Figure 24. Columbia River temperature $\left({ }^{\circ} \mathrm{C}\right)$ at Rock Island Dam, April-October, 1987-1994 (Sources: U.S. Army Corps of Engineers data, University of Washington 1998; Fish Passage

Center, unpublished data) 37

\section{CHAPTER THREE:}

Figure 1. Mean $\left( \pm\right.$ SE) skin, nare, and vent mucus lysozyme concentrations $\left(\mu \mathrm{g} \cdot \mathrm{mL}^{-1} \mathrm{HEWL}\right)$ in juvenile coho salmon used in raceway cover experiments at Willard National Fish Hatchery, 1993 to 1994

Figure 2. Mean $( \pm \mathrm{SE})$ skin, nare, and vent mucus lysozyme concentrations $\left(\mu \mathrm{g} \cdot \mathrm{mL}^{-1} \mathrm{HEWL}\right)$ of spring chinook salmon used in raceway cover experiments at Little White Salmon National Fish Hatchery, 1993 to 1994 70

Figure 3. Mean $( \pm \mathrm{SE})$ plasma lysozyme concentration $\left(\mu \mathrm{g} \cdot \mathrm{mL}^{-1} \mathrm{HEWL}\right)$ in juvenile spring chinook salmon after challenge with Renibacterium salmoninarum, versus control fish, in 1993. Disease challenges were administered on 5/20/93 and 8/24/93; a stress challenge was administered on 11/16/93. Asterisks mark dates of significant difference between treatment and control groups 71

Figure 4. Mean $( \pm \mathrm{SE})$ skin mucus lysozyme concentration $\left(\mu \mathrm{g} \cdot \mathrm{mL}^{-1} \mathrm{HEWL}\right)$ in juvenile spring chinook salmon experimentally challenged with Renibacterium salmoninarum, versus control fish, in 1993. Disease challenges were administered on 5/20/93 and on 8/24/93; a stress challenge was administered on 11/16/93. Asterisks denote dates of significant difference between control and disease-challenged groups 
Figure 5. Mean $( \pm \mathrm{SE})$ vent mucus lysozyme concentration $\left(\mu \mathrm{g} \cdot \mathrm{mL}^{-1} \mathrm{HEWL}\right)$ in juvenile spring chinook salmon challenged with exposure to Renibacterium salmoninarum, versus control fish, in 1993. Disease challenges were administered on 5/20/93 and 8/24/93; a stress challenge was administered on $11 / 16 / 93$. Asterisks mark dates of significant difference between control and treatment groups

Figure 6. Mean $( \pm \mathrm{SE})$ skin mucus lysozyme concentrations $\left(\mu \mathrm{g} \cdot \mathrm{mL}^{-1} \mathrm{HEWL}\right)$ in juvenile spring chinook salmon challenged with exposure to Renibacterium salmoninarum, versus control fish, in 1994. The disease challenge was administered on 6/1/94. Asterisks mark dates of significant difference between values for treatment and control fish

Figure 7. Mean $( \pm \mathrm{SE})$ nare mucus lysozyme concentrations $\left(\mu \mathrm{g} \cdot \mathrm{mL}^{-1} \mathrm{HEWL}\right)$ in juvenile spring chinook salmon challenged with Renibacterium salmoninarum, versus control fish, in 1994. The disease challenge was administered on 6/1/94. Asterisks denote significant difference between control and treatment groups

Figure 8. Mean $( \pm \mathrm{SE})$ vent mucus lysozyme concentration $\left(\mu \mathrm{g} \cdot \mathrm{mL}^{-1} \mathrm{HEWL}\right)$ in juvenile spring chinook salmon challenged with exposure to Renibacterium salmoninarum, versus control fish, in 1994. The disease challenge was administered on 6/1/94 .............. 76 


\section{LIST OF ASCTTA REPORTS}

Beeman, J. W., D. W. Rondorf, J. C. Faler, M. E. Free, and P. V. Haner. 1990. Assessment of smolt condition for travel time analysis. Annual report 1989 (Contract DE-A17987BP35245) to Bonneville Power Administration, Portland, Oregon.

Beeman, J. W., D. W. Rondorf, J. C. Faler, M. E. Free, P. V. Haner, S. T. Sauter, and D. A. Venditti. 1991. Assessment of smolt condition for travel time analysis. Annual Report 1990 (Contract DE-A179-87BP35245) to Bonneville Power Administration, Portland, Oregon.

Maule, A. G., J. W. Beeman, R. M. Schrock, and P. V. Haner. 1994. Assessment of smolt condition for travel time analysis. Annual report 1991-1992 (Contract DE-A17987BP35245) to Bonneville Power Administration, Portland, Oregon.

Rondorf, D. W., J. W. Beeman, M. E. Free, and D. E. Liljegren. 1988. Correlation of biological characteristics of smolts with survival and travel time. Annual report 1987 (Contract DEA179-87BP35245) to Bonneville Power Administration, Portland, Oregon.

Rondorf, D. W., J. W. Beeman, J. C. Faler, M. E. Free, and E. J. Wagner. 1989. Assessment of smolt condition for travel time analysis. Annual report 1988 (Contract DE-A17987BP35245) to Bonneville Power Administration, Portland, Oregon.

Schrock, R. M., J. W. Beeman, P. V. Haner, K. M. Hans, J. D. Hotchkiss, S. T. Sauter, S. P. VanderKooi, W. L. Gale, P. A. Petrusso, and A. G. Maule. 1998. Assessment of smolt condition for travel time analysis. Project review 1987-1997. Report (Contract DEA179-87BP35245) to Bonneville Power Administration, Portland, Oregon. Internet publication at http://www.efw.bpa.gov/Environment/EW/EWP/DOCS/REPORTS/ DOWNSTRM/withpdf.htm. 


\section{LIST OF RELATED PUBLICATIONS}

Beeman, J. W., D. W. Rondorf, and M. E. Tilson. 1994. Assessing smoltification of juvenile spring chinook salmon (Oncorhynchus tshawytscha) using changes in body morphology. Canadian Journal of Fisheries and Aquatic Sciences 51:836-844.

Beeman, J. W., D. W. Rondorf, M. E. Tilson, and D. A. Venditti. 1995. A non-lethal measure of smolt status of juvenile steelhead based on body morphology. Transactions of the American Fisheries Society 124:764-769.

Haner, P. V., J. C. Faler, R. M. Schrock, D. W. Rondorf, and A. G. Maule. 1995. Skin reflectance as a non-lethal measure of smoltification for juvenile salmonids. North American Journal of Fisheries Management 15:814-822.

Jones, R. N., and H. L. Burge. 1993. An evaluation of the effects of release time on the postrelease performance and adult returns of spring chinook salmon at Dworshak and Kooskia National Fish Hatcheries in 1993. Progress Report to Lower Snake River Compensation Plan Office, Idaho Fishery Resource Office, U. S. Fish and Wildlife Service, Ahsahka, Idaho.

Jones, R. N., and H. L. Burge. 1994. An evaluation of the effects of release time on the postrelease performance and adult returns of spring chinook salmon at Dworshak and Kooskia National Fish Hatcheries in 1994. Progress Report to Lower Snake River Compensation Plan Office, Idaho Fishery Resource Office, U. S. Fish and Wildlife Service, Ahsahka, Idaho.

Muir, W. D., S. G. Smith, R. N. Iwamoto, D. J. Kamikawa, K. W. McIntyre, E. E. Hockersmith, B. P. Sandford, P. A. Ocker, T. E. Reuhle, J. G. Williams, and J. R. Skalski. 1995. Survival estimates for the passage of yearling salmonids through Snake River dams and reservoirs, 1994. Annual report (Project Number 93-29) to Bonneville Power Administration, Portland, Oregon, and U.S. Army Corps of Engineers, Walla Walla District, Walla Walla, Washington.

Schrock, R. M., J. W. Beeman, D. W. Rondorf, and P. V. Haner. 1994. A microassay for gill sodium, potassium-activated ATPase in juvenile Pacific salmonids. Transactions of the American Fisheries Society 123:223-229. 


\title{
CHAPTER ONE
}

\section{Profiles of Gill Sodium, Potassium-Activated ATPase as an Index of Smoltification in Hatchery and Wild Salmonids}

\author{
Karen M. Hans \\ Alec G. Maule \\ John W. Beeman \\ Philip V. Haner \\ Jack D. Hotchkiss \\ Robin M. Schrock \\ Scott P. VanderKooi
}

\begin{abstract}
Seasonal profiles of smoltification of run-at-large groups of hatchery and wild stocks of chinook salmon, steelhead, and sockeye salmon were determined by monitoring of gill $\mathrm{Na}^{+}, \mathrm{K}^{+}-$ ATPase at hatcheries, traps, and dams on the Snake and Columbia rivers. A general increase in gill ATPase activity occurred over the migration season, and as fish moved downstream. The effect of annual differences in flow and temperature on the observed range of ATPase activities is discussed.
\end{abstract}

\section{INTRODUCTION}

Many agencies with biological and economic interests in water resource distribution in the Columbia River basin cooperate to ensure the successful seaward migration of juvenile Pacific salmonids (Oncorhynchus spp.). Recent extensive modifications to fish passage facilities and hydrosystem configurations were designed to reduce delays in juvenile salmonid migration caused by river impoundment, which is believed to contribute to declines in adult returns. The delays are thought to arise from the interactions between fish physiological development and environmental factors, especially water flow and temperature, which alter migration behavior. We monitored gill sodium, potassium-activated adenosine triphosphatase $\left(\mathrm{Na}^{+}, \mathrm{K}^{+}\right.$-ATPase) activity in juvenile salmonids to assess smoltification level and migratory readiness prior to release from hatcheries and during smolt emigration. Such information can be used to guide water management decisions, particularly flow regulation, so as to minimize travel time by consideration of the physiological status of juvenile salmonids in the river. Weekly reports of ATPase results to the Fish Passage Center were used to determine allotments from the Water Budget to increase flows during critical periods of the juvenile migration.

Sodium, potassium-activated ATPase is an enzyme involved in the absorption of $\mathrm{NaCl}$ across the gill epithelium of freshwater teleosts. In anadromous juvenile salmonids, ATPase is also involved in excretion of $\mathrm{NaCl}$ upon entry into saltwater, when the flow of salts across the 
gills is reversed (Hoar and Randall 1984; Borgatti et al. 1992). The determination of gill ATPase activity is an established method of assessing level of smoltification in juvenile salmon (Folmar and Dickhoff 1981; Zaugg 1982a; Dickhoff et al. 1985). Gill ATPase is often used in combination with other morphological, physiological and environmental variables as an indicator of smoltification (Wedemeyer et al. 1980; Folmar and Dickhoff 1981; Zaugg 1982a; Dickhoff et al. 1985; Sower and Fawcett 1991). Reporting of gill ATPase activity on a weekly basis has been a routine part of smolt monitoring programs in the Columbia River basin (Beeman et al. 1991; Maule et al. 1994).

Absolute concentrations of gill ATPase vary among species and stocks, but there is a characteristic profile of enzyme activity common to seaward-migrating salmonids. During hatchery residence, juvenile salmon exhibit low ATPase activity, with only a gradual increase over time (Beeman et al. 1991; Maule et al. 1994). A rapid rise in ATPase activity occurs after the fish are released into the river, and the increase in activity continues until late in the migration (Beeman et al. 1991). If release from hatcheries is delayed, fish may experience decreased ATPase activity, followed by rapid increases upon release and during migration (Zaugg 1982a). Monitoring of annual smoltification profiles of salmonid stocks and evaluation of changes related to environmental factors allows identification of sources of variation among years. The objectives of this study were to: 1) determine the level of smoltification, as indicated by gill ATPase activity, in juvenile yearling (spring/summer) chinook salmon (O. tshawytscha), subyearling (fall) chinook salmon, sockeye salmon $(O$. nerka), and steelhead (O. mykiss) prior to release from hatcheries; and 2) describe ATPase activity in hatchery and wild fish from the run-at-large during seaward emigration. Results were provided to the Fish Passage Center for in-season management of Water Budget flows to promote juvenile salmonid migration.

\section{METHODS}

\section{Sample Sites}

\section{Hatcheries}

In 1993 and 1994, spring chinook salmon were sampled at Sawtooth Hatchery and Rapid River Hatchery (Idaho Department of Fish and Game, IDFG), and Dworshak National Fish Hatchery (NFH) in Idaho; and Ringold Hatchery (Washington Department of Fish and Wildlife, WDFW), Entiat NFH, Leavenworth NFH, and Winthrop NFH in Washington. Dworshak NFH spring chinook salmon were sampled three times before release as part of a study designed to determine how release time affected migration rates (Jones and Burge 1993, 1994). Summer chinook salmon were sampled at McCall Hatchery (IDFG) in 1993 and 1994, and at Wells Hatchery (WDFW) in Washington in 1994 only. Steelhead were sampled at Dworshak NFH, and at Irrigon Hatchery (Oregon Department of Fish and Wildlife, ODFW) during 1993 only. Subyearling fall chinook salmon were sampled at Priest Rapids Hatchery and Turtle Rock Hatchery (WDFW) in Washington. Five release groups of fall chinook salmon from Priest Rapids Hatchery were also sampled at the 50th percentile of passage of the group through McNary Dam each year to determine travel times of marked groups of serially-released fish. 


\section{Traps}

In 1993, we sampled fish at traps operated by IDFG on the Salmon River, Clearwater River and Snake River. Fish collected at these traps were held up to $24 \mathrm{~h}$, anaesthetized and tagged with passive integrated transponder (PIT)-tags, then sampled for ATPase with a small, non-lethal gill clip. The Columbia and Snake rivers experienced above-normal precipitation and river flow rates during spring 1993. Because of high flows, sampling was terminated earlier than planned at the Clearwater River and Salmon River traps, and was suspended at the Snake River Trap for a period of 17 days. In 1994, sampling was conducted at the Salmon, Clearwater, and Snake River traps and at two additional sites: the Imnaha River Trap, operated by the Nez Perce Indian Nation, and the Grande Ronde River Trap, operated by ODFW.

\section{Dams}

Sampling of chinook salmon and steelhead was conducted at juvenile bypass facilities at Rock Island, McNary, John Day and Bonneville dams on the Columbia River, and at Lower Granite and Little Goose dams on the Snake River in 1993 and 1994. Sockeye salmon of hatchery and wild origin were sampled at Rock Island Dam.

At smolt traps and dam collection facilities, we sampled both adipose fin-clipped and nonadipose fin-clipped chinook salmon and steelhead. Adipose fins of all hatchery steelhead in the Columbia River basin were removed by clipping before release, therefore all migrating steelhead with intact adipose fins were assumed to be of wild origin. Snake River hatchery chinook salmon were also adipose fin-clipped, and could be distinguished from wild fish at Snake River dams. However, chinook salmon with intact adipose fins captured from the Columbia River could have been of wild or hatchery origin due to release of unmarked fish from mid-Columbia basin hatcheries. Thus a comparison of wild and hatchery chinook salmon at mainstem Columbia River dams was not possible.

\section{Sample Sizes}

Our objective at hatcheries was to obtain 30 fish per sample. The sample size at hatcheries was determined by power analysis to allow differentiation between parr and smolts based on ATPase values. At traps and dams, the sampling goal was to collect 20 to 40 spring chinook salmon and 12 to 25 steelhead per site per day; sample sizes were determined by the number of PIT-tagged fish we expected to detect at downstream collection sites. Frequently, sample sizes at traps and dams were not attained on a given day, and more fish were sampled in subsequent days to reach weekly goals.

\section{Tissue Collection and Analysis}

Fish collected at hatcheries, traps, or dams were anaesthetized in 50 to $80 \mathrm{mg} \cdot \mathrm{L}^{-1}$ tricaine methanesulfonate (MS-222), weighed to the nearest $0.1 \mathrm{~g}$, and measured to the nearest millimeter fork length. A small piece of gill filament (about $2 \times 3 \mathrm{~mm}$; wet weight about $10 \mathrm{mg}$ ) was clipped 
from the center third of the first gill arch on the left side of the fish. After fish were gill-clipped, they were allowed to recover in aerated water for 15 to $120 \mathrm{~min}$ and were then returned to the hatchery pond, river or juvenile bypass system. Gill tissue samples were placed in $1.5 \mathrm{~mL}$ microcentrifuge tubes and preserved in $0.5 \mathrm{~mL}$ chilled ATPase buffer solution. Samples were shaken to break up filaments, set in an ice water bath for at least $5 \mathrm{~min}$, frozen in liquid nitrogen for transport, and later stored at $-80^{\circ} \mathrm{C}$. At the time of each sampling, we recorded water temperature and noted the external condition of each fish (e.g., descaling, lesions, and parasites). The microassay method developed by Schrock et al. (1994) was used for sampling and analysis to determine ATPase levels in gill tissue. Gill ATPase activity is reported here in units of

micromoles inorganic phosphate per milligram protein per hour $\left(\mu \mathrm{mol} \mathrm{P}_{\mathrm{i}} \cdot \mathrm{mg} \operatorname{protein}^{-1} \cdot \mathrm{h}^{-1}\right)$.

\section{RESULTS}

\section{Results}

The Assessment of Smolt Condition for Travel Time Analysis project collected 8,512 gill samples in 1993 using the non-lethal gill ATPase microassay. Sampling of 16 release groups was completed at 12 hatcheries in the Snake and Columbia River basins. Wild and hatchery steelhead, yearling chinook salmon, subyearling chinook salmon, and sockeye salmon were also sampled at 3 smolt traps and 6 hydropower dams in the region.

\section{Yearling Chinook Salmon \\ Hatcheries}

In 1993, yearling spring chinook salmon at Dworshak NFH showed an increase in mean ATPase levels from 7.7 to 10.7 units between March 22 and April 19 (Figure 1a). Yearling spring and summer chinook salmon in other Snake River and Columbia River basin hatcheries showed similar mean ATPase levels, ranging between 10.0 and 14.0 units, except for spring chinook salmon from Ringold Hatchery, which had the highest mean ATPase value (15.2 units) (Figure 1b). Water temperature at Ringold was $13^{\circ} \mathrm{C}$ at the time of sampling, compared to 5 to 6 ${ }^{\circ} \mathrm{C}$ at the other hatcheries.

\section{Traps}

Clearwater River Trap. The mean ATPase levels for hatchery chinook salmon at the Clearwater River Trap started at 9.5 units, then gradually increased to 17.9 units by May, when the trap was closed due to high river flows. Mean ATPase levels for wild fish ranged between 13.6 and 18.2 before the first week of May, when the mean activity reached 22.9 units (Figure 2a).

Salmon River Trap. Mean ATPase levels for hatchery chinook salmon at the Salmon River Trap ranged between 9.1 and 17.4 units. ATPase levels of wild fish had a higher range, from 16.2 to 20.5 units, throughout the sampling season (Figure $2 \mathrm{~b}$ ).

Snake River Trap. For the first three weeks of the 1993 sampling season, mean ATPase levels of hatchery chinook salmon at the Snake River Trap ranged between 10.9 and 16.3 units (Figure 2c). 
The week of May 3, ATPase increased to 21.5 units and remained high until mid-May, when sampling was suspended for 17 days because of high flows. When the trap reopened, mean ATPase levels remained elevated in June. Mean ATPase levels of wild fish were high during the entire season. Mean activities were 18.9 on the first sample date in mid-April, peaked at 29.9 units early in May, and remained above 15 units for the rest of the sampling period (Figure 2c).

Snake River Dams

Lower Granite Dam. Hatchery chinook salmon at Lower Granite Dam had relatively constant ATPase levels throughout the sampling season, ranging from 20.6 to 25.5 units (Figure $3 \mathrm{a}$ ). Mean ATPase activities in wild chinook salmon were in a higher range, starting at 33.2 units, then ranging between 23.2 to 31.0 units for the rest of the season (Figure 3a).

Little Goose Dam. Mean ATPase levels in hatchery chinook salmon monitored at Little Goose Dam ranged between 24.0 and 30.3 units throughout the sampling season (Figure $3 \mathrm{~b}$ ).

\section{Columbia River Dams}

Rock Island Dam. Mean ATPase levels for yearling chinook salmon sampled at Rock Island Dam varied considerably during the sampling season. Initial mean activity for fish with intact adipose fins (wild or hatchery fish) was low at 9.0 units. Mean levels increased to a peak of 30.1 units as the season progressed, then fell to 14.4 units at the final sample (Figure 4a). Levels for adipose fin-clipped fish (hatchery fish) were initially low (9.5 units) at the start of the season. Mean levels for hatchery fish peaked at 29.1 units, and gradually declined to a final value of 20.4 units on the last day of sampling.

McNary Dam. ATPase activities in yearling chinook salmon with intact adipose fins (wild or hatchery fish) at McNary Dam varied within a narrow range during the sampling season, beginning at 17.9 units, increasing to 27.5 units, then dropping to 24.1 units. Adipose fin-clipped yearling chinook salmon (hatchery fish) at McNary Dam were sampled on May 12 and May 26, with mean ATPase levels of 25.9 and 19.9 units, respectively (Figure 4b).

\section{Subyearling Chinook Salmon}

Hatcheries

Subyearling (fall) chinook salmon sampled at Turtle Rock Hatchery had slightly higher mean ATPase (17.0 units) than fall chinook from Priest Rapids Hatchery sampled on two dates (13.4 and 12.4 units) (Figure 1c). Water temperatures $\left(14\right.$ to $15^{\circ} \mathrm{C}$ ) were similar for both sites.

\section{Columbia River Dams}

Rock Island Dam. The initial mean ATPase activity of 24.0 ATPase units in subyearling (fall) chinook salmon at Rock Island Dam dropped to 13.2 units on July 6, then peaked at 25.5 on July 13. Mean ATPase activity on the final sample date was 24.5 units (Figure 5a).

McNary Dam. Subyearling (fall) chinook salmon sampled at McNary Dam on the mainstem of the Columbia River had mean ATPase activities ranging from 22.3 to 31.7 units early in the 
migration season, in June and July. Beyond mid-July, mean ATPase levels slowly decreased, with minor fluctuations, to a low of 15.2 units in October (Figure 5b).

John Day Dam. Mean ATPase levels for fish at John Day Dam was 20.7 units on the first day of sampling, increasing to 29.5 units as the season progressed, and declining to means of about 20 units or less on the final three sampling dates (Figure $5 \mathrm{c}$ ).

Bonneville Dam. From an initial mean of 22.0 units for subyearling (fall) chinook salmon at Bonneville Dam, ATPase activity increased sharply to 31.5 a week later, and was 25.1 units when sampling ceased in September (Figure 5c).

\section{Steelhead}

Hatcheries

Steelhead from Irrigon Hatchery had a higher mean ATPase activity (13.3 units) than steelhead sampled at Dworshak NFH (10.9 units) (Figure 1d). Water temperature at Irrigon (10 $\left.{ }^{\circ} \mathrm{C}\right)$ was higher than at Dworshak NFH $\left(5^{\circ} \mathrm{C}\right)$ at the time of sampling.

\section{Traps}

Salmon River Trap. Mean ATPase activities in both hatchery and wild steelhead at the Salmon River Trap gradually increased during the season. Hatchery fish had a lower range of mean activities (6.8 to 12.8 units) than wild fish (10.5 to 15.9 units) (Figure 6a).

Snake River Trap. Mean ATPase activity in wild and hatchery steelhead captured in the Snake River Trap differed throughout the 1993 sampling season. Mean ATPase activities were generally higher in wild fish, ranging between 13.9 and 24.2 units, whereas mean activities for hatchery fish were between 10.1 and 19.6 units (Figure 6b).

\section{Snake River Dams}

Lower Granite Dam. The range of mean ATPase activities for wild steelhead (20.0 to 26.1) at Lower Granite Dam was higher than for hatchery steelhead (12.9 to 20.3) (Figure 7a).

Little Goose Dam. At Little Goose Dam, mean ATPase levels for steelhead were consistently higher in wild fish (19.4 to 28.2 units) than in hatchery fish (16.0 to 23.2 units) (Figure 7b).

\section{Columbia River Dams}

Rock Island Dam. Hatchery and wild steelhead at Rock Island Dam had similar mean ATPase activities throughout the season, with an approximate range of 14 to 20 for hatchery fish and 13 to 23 units for wild fish. Mean levels in hatchery fish were generally lower on a given sample date (Figure 8a).

McNary Dam. Differences in ATPase levels between hatchery and wild steelhead were seen early in 1993, when the mean ATPase activity was 28.9 units for wild fish and 17.7 units for hatchery fish. Activities of wild and hatchery fish converged during May, and values for both wild and hatchery fish decreased from mid-May through the last sample date (Figure 8b). 


\section{Sockeye Salmon}

Rock Island Dam. Wild sockeye salmon sampled at Rock Island Dam had moderately high mean ATPase values, ranging between 21.1 and 25.0 units in April. Activity peaked in mid-May, with a mean value of 40.5 units, then decreased to range between 25.6 and 35.4 units for the rest of the season. The range of mean ATPase activities in hatchery sockeye salmon (25.1 to 44.3 units) was similar to the range in wild sockeye throughout May, but changes in activity levels occurred on different dates (Figure 9).

\section{Results}

In 1994, sampling of 15 release groups was completed at 11 hatcheries. Migrants of wild and hatchery origin were sampled at 5 traps on the Snake River and its tributaries, and 6 hydropower dams on the Snake and Columbia rivers.

\section{Yearling Chinook Salmon Hatcheries}

Mean ATPase levels in yearling spring chinook salmon at Dworshak NFH ranged from 5.4 to 11.1 units between March 2 and May 3 (Figure 10a). Yearling spring chinook salmon at other hatcheries showed similar mean ATPase ranges, between 8.0 and 16.2 units. As in 1993, Ringold Hatchery yearling chinook salmon had the highest ATPase activity (25.4 units) of all hatcheries studied (Figure 10b). Water temperature at Ringold was $13{ }^{\circ} \mathrm{C}$ at the time of sampling, compared with 5 to $6^{\circ} \mathrm{C}$ at the other hatcheries.

The mean ATPase activity for yearling summer chinook salmon sampled at McCall Hatchery on March 30 was 11.2 units (Appendix H.4). Summer chinook salmon at Wells Hatchery had mean ATPase activities of 9.4 on April 12 and 10.4 on June 14 (Appendix H.4).

\section{Traps}

Clearwater River Trap. Mean ATPase levels for hatchery chinook salmon at the Clearwater River Trap varied between 8.0 and 15.3 units during sampling from early April to mid-May (Figure 11a). Mean ATPase levels for wild fish were higher and ranged between 10.6 and 21.0 units during the same period (Figure 11a).

Salmon River Trap. During 1994, mean ATPase levels for hatchery chinook salmon at the Salmon River Trap increased from 8.1 units in mid-April, to 15.9 units in late May when sampling was completed (Figure 11b). The mean ATPase activity of wild fish fluctuated between 12.0 and 18.2 units during the sampling season (Figure 11b).

Snake River Trap. Mean ATPase levels of hatchery chinook salmon at the Snake River Trap slowly rose from 8.5 to 24.8 units during trap operation from April 13 to May 27 (Figure 11c). Mean ATPase levels for wild fish were between 11.5 and 15.8 units in April, and between 11.2 and 22.1 units in May (Figure 11c). 
Imnaha River Trap. The range of ATPase activity in wild spring chinook salmon sampled at the Imnaha River Trap was slightly higher (10.6 to 15.3 units) than that of hatchery fish (9.0 to 13.3 units) (Figure 12a).

Grande Ronde River Trap. Hatchery spring chinook salmon were sampled on only three dates from mid-April to early May at the Grande Ronde River Trap in 1994, and sample sizes were small $(n \leq 5)$ on 2 of the 3 sample dates. Mean ATPase activities were between 10.4 and 16.4 units. Wild spring chinook salmon were sampled more often during the season, from mid-April to late May, and sample sizes were greater than or equal to 5 on 6 of the 12 sample dates. Mean ATPase levels for wild fish ranged between 8.3 (May 18) and a peak activity of 22.9 units (May 3) (Figure 12b).

\section{Snake River Dams}

Lower Granite Dam. During 1994, mean ATPase levels for hatchery chinook salmon at Lower Granite Dam were relatively constant throughout the sampling season: the mean was initially 16.5 units, and varied between 11.9 and 22.0 units during April and May (Figure 13). For wild fish, mean ATPase activities equaled or exceeded levels in hatchery migrants, decreasing slightly from activities around 30 (29.5 and 30.8 units) on the first two sample days, to range between 18.9 and 26.2 units for the rest of the sampling period in late May (Figure 13).

\section{Columbia River Dams}

Rock Island Dam. Considerable variation in mean ATPase levels was seen in yearling chinook salmon with intact adipose fins (wild or hatchery origin) and those with clipped adipose fins (hatchery origin) at Rock Island Dam throughout the sampling season in 1994 (Figure 14a). Activities in unmarked fish were above 20 units on all four sampling dates in late May.

McNary Dam. At McNary Dam, mean ATPase levels for yearling chinook salmon with intact adipose fins (wild or hatchery origin) ranged between 15.7 and 24.9 units (Figure 14b). Adipose fin-clipped yearling hatchery chinook salmon had consistently higher mean ATPase activities, ranging from 16.3 to 26.2 units over the same sampling period (Figure 14b).

\section{Subyearling Chinook Salmon \\ Hatcheries}

Subyearling (fall) chinook salmon at Priest Rapids Hatchery in 1994 had mean ATPase levels of 5.9 on June 9 and 5.5 units on June 15 (Appendix H.2).

\section{Columbia River Dams}

Rock Island Dam. During the sampling season in 1994, mean ATPase levels of subyearling (fall) chinook salmon at Rock Island Dam ranged between 8.5 and 17.9 units (Figure 15a).

McNary Dam. At McNary Dam, mean ATPase levels of subyearling (fall) chinook salmon ranged from 9.9 to 25.0 units, with levels tending to decrease toward the end of the sampling period (Figure 15b). 
John Day Dam. Mean ATPase levels for subyearling chinook salmon collected at John Day Dam between late June and early September ranged from 11.5 to 22.8 units (Figure 15c).

\section{Steelhead}

Hatcheries

Steelhead sampled at Dworshak NFH on a single date before release (April 28) had a mean ATPase activity of 8.9 units (Appendix H.3).

\section{Traps}

Salmon River Trap. Mean ATPase levels in hatchery steelhead at the Salmon River Trap showed little variation in April and May, and declined during the season from a mean of 9.7 to 7.0 units (Figure 16a). Wild steelhead, captured in much fewer numbers, had higher mean ATPase activities and demonstrated more variability throughout the season than hatchery fish. Mean activities of wild steelhead ranged from 6.2 to the peak in early May of 13.7 units (Figure 16a).

Snake River Trap. During 1994, mean ATPase levels of hatchery steelhead at the Snake River Trap, remained low over the course of the season, between 7.2 and 13.2 units, with activities being more consistent in May (Figure 16b). Levels for wild fish were generally higher than levels in hatchery fish, except for the first and last sample dates. Mean activities ranged from 6.9 to 16.1 units, with higher activities recorded during the first month of the sampling season, April 5 to May 5 (Figure 16b).

Imnaha River Trap. Hatchery steelhead were sampled at the Imnaha River Trap for only two weeks in 1994. Mean ATPase levels in hatchery steelhead were low, ranging from only 7.6 to 10.4 units (Figure 17a). Mean ATPase levels were higher in wild steelhead than hatchery fish, peaking at 16.2 units during the same sampling period (Figure 17a).

Grande Ronde River Trap. Mean ATPase levels for wild steelhead were higher than levels for hatchery fish, with a peak activity of 14.1 units, compared to 9.5 units in hatchery steelhead (Figure 17b).

\section{Snake River Dams}

Lower Granite Dam. In 1994, mean ATPase levels for hatchery steelhead at Lower Granite Dam ranged between 10.7 and the season peak of 16.3 units on May 13 (Figure 18). Wild steelhead ATPase activity ranged from 12.7 to the peak of 19.1 units on May 6; the peak occurred a week earlier than the peak for hatchery fish (Figure 18).

\section{Columbia River Dams}

Rock Island Dam. In 1994, mean ATPase levels in hatchery steelhead rose from 13.8 units in April, peaked at 19.1 units, and remained at approximately 15 units through the end of sampling (Figure 19a). Wild fish initially had similar levels--rising from 13.1 ATPase units to the peak mean activity of 19.4 units--but showed a higher mean activity, than hatchery fish for the rest of the sampling season (Figure 19a). 
McNary Dam. Wild steelhead displayed mean ATPase activities that were slightly higher than that of hatchery fish during sampling from late April to early June (Figure 19b).

\section{Sockeye Salmon}

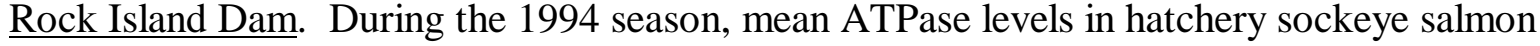
fluctuated between 21.7 and 45.4 ATPase units. Mean ATPase levels for wild fish ranged from a low of 13.5 units to a high of 35.8 units (Figure 20). Total sample sizes in 1994 were small for both wild $(N=231)$ and hatchery fish $(N=93)$.

\section{DISCUSSION}

The purpose of the Assessment of Smolt Condition for Travel Time Analysis project has been to evaluate smoltification in juvenile salmonids to determine how fish physiology, interacting with the river environment, affects migration rate or travel time. The complex interactions among biotic and abiotic variables, including gill ATPase activity, condition factor, river flow and temperature, and their effect on migration rates were discussed by Maule et al. (1994). Physiological data was provided by the ASCTTA project to the Fish Passage Center during peak migration times to assist in flow augmentation management. A significant change in the Smolt Monitoring Program of the Fish Passage Center occurred in 1993, with discontinuation of freezebrand marking of hatchery release fish to monitor travel time through specific reaches between dams on the Snake and Columbia rivers. This report presents a seasonal profile of smoltification at specific sites during the juvenile migration of run-at-large fish by species, age group, and origin (wild or hatchery fish).

Seasonal profiles of smoltification, as described by gill $\mathrm{Na}^{+}, \mathrm{K}^{+}$-ATPase activity of run-atlarge fish, were compared with data from the seven previous years on marked hatchery groups of known origin. During the 1993 and 1994 migrations, monitoring of the migration-at-large showed seasonal patterns of smolt development in all species groups similar to those demonstrated in groups of marked hatchery fish in previous years (Rondorf et al. 1988, 1989; Beeman et al. 1990, 1991; Maule et al. 1994). Discontinuation of freeze-branding of hatchery release fish to monitor travel time through specific reaches eliminated the ability to identify changes in migration characteristics of individual hatchery stocks. However, the run-at-large demonstrated similar smoltification profiles, though the magnitude of change over the season was somewhat reduced. Gill $\mathrm{Na}^{+}, \mathrm{K}^{+}$-ATPase activity in species sampled at release at hatcheries was lower than that of hatchery fish sampled at traps or dams. Pre-release sampling for gill $\mathrm{Na}^{+}, \mathrm{K}^{+}-$ ATPase activities at hatcheries was reduced to a single sample, thus eliminating the possibility of determining whether ATPase levels were decreasing from a pre-release peak or increasing. In both 1993 and 1994, yearling hatchery spring chinook salmon had mean ATPase activities that were $\leq 16$ units before release, with the exception of Ringold fish (25 units) (Figures 1 and 10). Yearling spring chinook salmon at traps and dams experienced increasing ATPase activity as they migrated further downriver (Figures 2-4 and 11-14). Mean activities of 20 units or greater were typical during the middle part of the migration, and levels increased as the season progressed.

Activities were higher at traps than at hatcheries, and higher at dams than at traps. ATPase activities at lower river dams such as Rock Island on the mid-Columbia, Lower Granite 
on the Snake River, and McNary on the mainstem Columbia, were generally higher than at the hatcheries and traps. However, levels in run-at-large yearling chinook salmon of unknown hatchery origin did not reach the high levels ( $\geq 30$ units) reported for individual hatchery groups in previous years (Rondorf et al. 1989; Beeman et al. 1990, 1991; Maule et al. 1994). Mean ATPase activities in late migrants showed a decrease, in some cases late in the season when flow was decreasing. The decrease in ATPase may have been the result of sampling fish that migrated more slowly as the result of slower physiological development. Because the origin and stock composition of a group of run-at-large fish is unknown at a given site on a particular sample date, comparison with previous data on marked groups of known origin is complicated by possible moderation of mean peak activities by the mixing of stocks at different levels of development. ATPase activities by date for yearling spring chinook of known hatchery origin, documented in earlier reports for 1988 and 1989 (Rondorf et al. 1989; Beeman et al. 1990), were much higher (30 to 40 units) at Rock Island and McNary Dams, than activities seen in the general run-at-large groups in 1993 and 1994 at those dams.

In 1993, an increase in ATPase activity in both hatchery and run-at-large (non-adipose finclipped) fish in late May at Rock Island Dam (Figure 4) corresponded to a peak in flow during that time (Figure 21) (University of Washington 1998). Flows at Rock Island Dam were higher in 1994 than in 1993 during April through July, except for the period May 7 through June 1.

Overall lower ATPase activities were seen in 1994 than in 1993 at Rock Island Dam (Figures 4 and 14). Gill ATPase activities at Rock Island Dam during 1993 and 1994 were much lower than in 1990, when fish were released with relatively high ATPase activities (e.g., Entiat NFH mean ATPase was 33 units at release) (Beeman et al. 1991), and flows were generally higher (Figure 21) (University of Washington 1998).

Peak flows in the Snake River at Lower Granite Dam in late May 1993 corresponding to the time of peak flows at Rock Island Dam, and flows in the Snake River in 1994 were almost uniformly lower than in 1993. With few exceptions, ATPase activities of both wild and hatchery yearling spring chinook salmon were lower in 1994 than in 1993 when sample site and date were considered.

Although flows at McNary Dam were almost twice as high in 1993 as in 1994 during May (Figure 22) (University of Washington 1998), and were the highest seen in late May during the previous 8 years, ATPase activities of yearling spring chinook during 1993 and 1994 were very similar and ranged from 15 to 25 units for the duration of the sampling season. Gill ATPase activities were higher at Rock Island Dam than at McNary Dam. Flows at McNary Dam in 1990 were similar to 1993 flows, but the duration of the peak flow in 1990 was longer and the peak occurred later.

Wild and hatchery yearling spring chinook salmon displayed similar seasonal profiles of ATPase activity, but the phasing of smoltification in wild and hatchery salmon differed, as measured by increases, peaks, and decreases in ATPase activity during the season and at individual sites. In almost every case, activities were higher in wild yearling chinook salmon than hatchery fish on all sample dates and at all sites. This was true for yearling chinook salmon sampled at the Salmon, Clearwater, and Snake River traps and at Rock Island and Lower Granite dams in 1993 and 1994. At McNary Dam, the difference in ATPase activities between wild and hatchery fish was negligible. Because yearling chinook salmon without adipose fin clips sampled in the mid-Columbia River could have been either wild or hatchery fish, true differences between 
wild and hatchery chinook salmon at Rock Island and McNary dams could not be determined. At Rock Island, the difference in mean ATPase activities between hatchery fish and fish with intact adipose fins, therefore of mixed origin, was not as marked as at traps and dams on the Snake River, where hatchery and wild fish were distinguishable. The presence of hatchery fish, which often have lower ATPase activities than wild fish, in the unmarked group may have reduced mean ATPase levels. Variation in the proportion of hatchery fish in the unmarked group passing a sampling site on a particular date would account for variation in the magnitude of differences between fin-clipped hatchery fish and those of unknown origin.

Mean ATPase activities of subyearling fall chinook salmon were higher in 1993 than in 1994 at Rock Island, McNary, and John Day dams. Fall chinook salmon migrate later than yearling spring chinook salmon, and therefore are exposed to different flow patterns during emigration. Mean ATPase activities in subyearling chinook salmon barely reached 20 units in 1994, whereas they ranged between 15 and 25 units in 1993. At McNary Dam, mean activities in 1993 exceeded 30 units in mid-July, but were only slightly above 20 units at any time in 1994. At John Day Dam, activities also approached 30 units in 1993, but remained below 25 in 1994 when flows at McNary Dam were low.

Steelhead exhibited a similar seasonal profile of ATPase activity as compared to chinook salmon. Activities were consistently higher in wild steelhead than in hatchery steelhead. In 1993, ATPase activities in both hatchery and wild steelhead were higher than in 1994. In steelhead, as in chinook salmon, the overall higher Snake River flows in 1993 were accompanied by overall higher ATPase activities. Flow is especially important to steelhead in determining migration rates (Maule et al. 1994). Zaugg et al. (1985) described the importance of in-river residence for gill ATPase levels and migration rates, and Maule et al. (1994) evaluated the relationship between flow and migration rates in marked groups of spring chinook salmon and steelhead. We have documented the same changes in run-at-large spring and fall chinook salmon in the Snake River.

Temperature has been shown to stimulate smoltification and higher ATPase levels in salmonids when increased within specific ranges (Zaugg 1981; Jonsson 1991). We compared temperature profiles at the sample sites to explain between-year differences. Water temperatures were consistently higher in 1994 than in 1993 at McNary Dam (Figure 23) (University of Washington 1998), but at Rock Island Dam, temperatures in 1993 exceeded those of 1994 during short periods within each month from June to September (Figure 24) (University of Washington 1998; Fish Passage Center, unpublished data). The overall higher temperatures in 1994, approaching temperatures known to adversely affect condition and health of migrating smolts, in combination with lower flows, may partially explain the system-wide lower ATPase activity profile of 1994.

An exception to the finding of higher ATPase activity in hatchery fish than in wild fish was sockeye salmon outmigrating from Lake Wenatchee. Fish of hatchery origin had higher mean ATPase levels than wild fish on most sample dates in both years, under the temperature and flow conditions described earlier. All hatchery fish sampled at Rock Island Dam in 1993 and 1994 came from a net pen operation in Lake Wenatchee. Hatchery sockeye salmon were transferred to the net pens as fry in April, and were released into the lake in late October. The hatchery fish migrated volitionally the following spring at the same time as the wild fish. Studies by Shrimpton et al. (1994) found that colonized hatchery Atlantic salmon (Salmo salar), released early to overwinter, were physiologically equivalent to wild fish with respect to ATPase level and 
seawater tolerance at the time of migration. Differences between mean ATPase levels of wild and hatchery salmon on specific sampling dates may be the result of differences in the time of peak migration between hatchery and wild fish. Wild spring chinook salmon tend to begin migrating through upriver sampling sites earlier than hatchery fish, which cannot migrate until they are released. For example, in 1994, wild fish were first collected at the Salmon River Trap on April 2, while the first hatchery fish reached the trap eight days later (April 10) (Fish Passage Center 1993, 1994). The difference in mean ATPase levels between wild and hatchery fish was most pronounced early in the season, and at upper-river sampling sites. In-river migration is known to promote smoltification and the disposition to migrate in hatchery-reared fish (Zaugg et al. 1985). As the season progressed, mean ATPase levels of wild and hatchery fish were more similar, suggesting that late-migrating hatchery fish had reached the same physiological level as lateemerging or late-migrating wild fish.

Differences in ATPase levels between wild and hatchery fish were not as pronounced in 1994 as in 1993. This may be related to the differences in river flow between the two years, as previously described. Beeman and Rondorf (1992) found travel time of juvenile salmonids decreased as flow increased. In a study of chinook salmon, Ewing et al. (1980) speculated that high flows could move fish downstream without a corresponding increase in ATPase level. Our data suggests that wild fish may migrate earlier than hatchery fish. Hatchery fish may be released when their ATPase levels are lower compared to wild fish, which migrate volitionally. Hatchery fish may require time after release to develop physiologically to a level equivalent to wild fish. Distances that wild and hatchery fish travel from their rearing site would also determine their physiological development level on the date and at the site of sampling. The hatchery stock of sockeye salmon we monitored, when allowed the opportunity to overwinter in the wild, developed ATPase activities equal to and exceeding those seen in the wild sockeye of the same region. It was beyond the scope of our evaluation to locate rearing areas to determine if the differences we saw between mean ATPase in the wild and colonized fish on specific dates were due to differences in rearing areas, emergence times or developmental stage.

Wild and hatchery fish sampled at dams and traps can come from many sources and reside in-river for varying lengths of time. The diversity of origins and natural variation among stocks within a species make it difficult to apply the smoltification levels of unmarked run-at-large fish to specific management goals. Data from earlier reports using marked groups of fish allowed for determination of travel times of known groups, in specific time periods, through individual river reaches. The travel times could be evaluated using the smolt indices, condition factor and gill ATPase, in combination with recorded flow and temperature, as groups of marked fish were identified at several locations during the migration.

Data collected on hatchery salmonids for this report suggests that the mean level of smoltification for run-at-large groups in 1993 and 1994 was similar to levels reported in previous years. In 1993, the mean ATPase activity for spring chinook salmon at Rock Island Dam corresponded to levels reported for mid-May 1989 (25 to 39 units), at approximately the same flow (175 kcfs) (Beeman et al. 1990). Gill ATPase results for hatchery and wild steelhead at Rock Island Dam in mid-May were also very similar to results in 1989, when flows were in the same range as in May 1993. The necessity of sampling fish from several hatcheries as a single 
group in the run-at-large may result in the reporting of mean ATPase activities different from what was found in previous years, when specific hatchery stocks were sampled at the same time in the migration. 
CHAPTER ONE FIGURES 

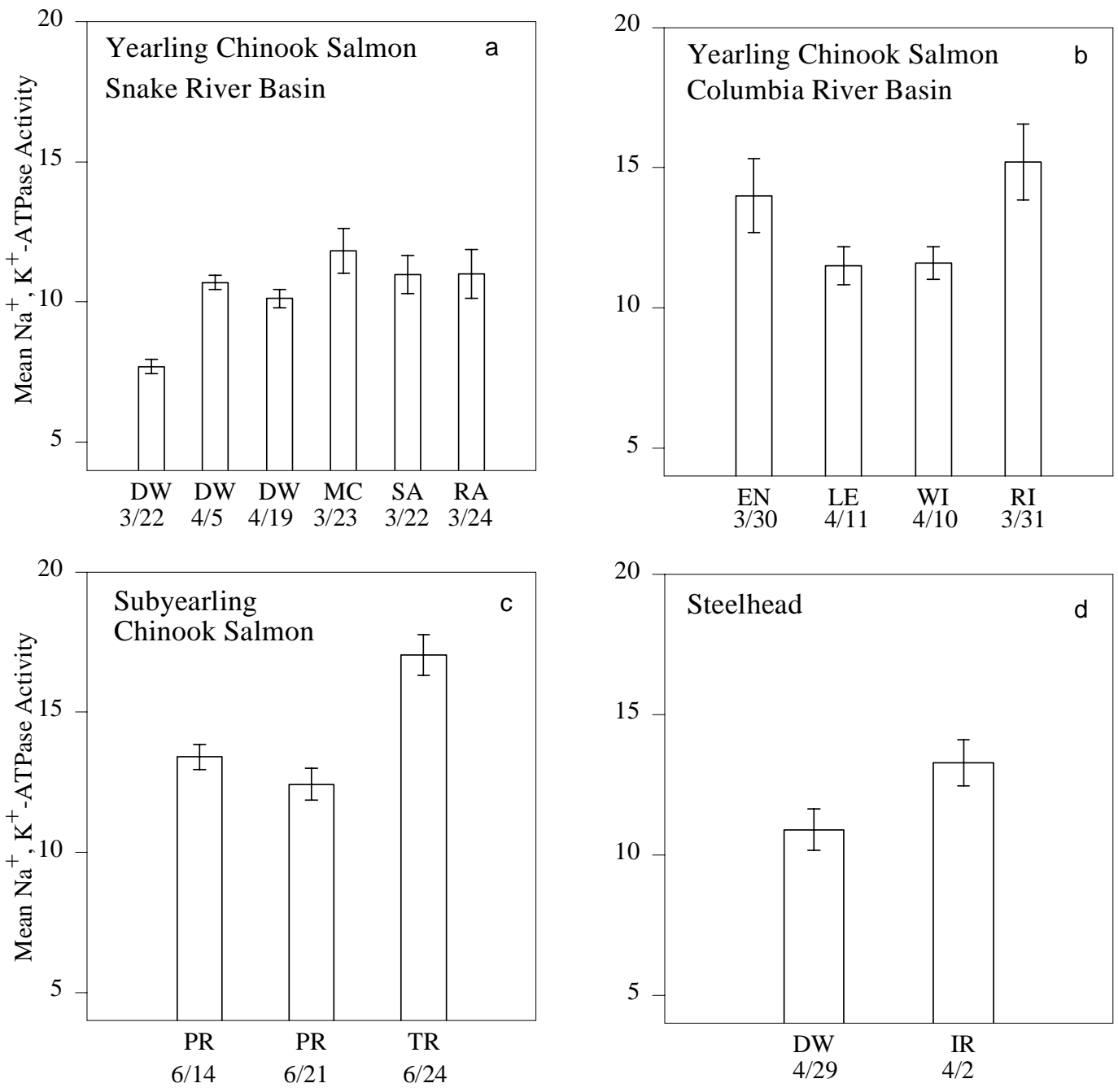

\begin{tabular}{|lll|}
\hline DW - Dworshak NFH & MC - McCall SFH & SA - Sawtooth SFH \\
EN - Entiat NFH & PR - Priest Rapids SFH & TR - Turtle Rock SFH \\
IR - Irrigon SFH & RA - Rapid River SFH & WI - Winthrop NFH \\
LE - Leavenworth NFH & RI - Ringold SFH & \\
\hline
\end{tabular}

Figure 1. Mean $( \pm \mathrm{SE})$ gill $\mathrm{Na}^{+}, \mathrm{K}^{+}$-ATPase activity $\left(\mu \mathrm{mol} \mathrm{P}_{\mathrm{i}} \cdot \mathrm{mg}\right.$ protein $\left.{ }^{-1} \cdot \mathrm{h}^{-1}\right)$ for yearling spring/summer chinook salmon sampled before release in 1993 from (a) Snake River basin hatcheries, and (b) Columbia River basin hatcheries; (c) subyearling chinook salmon before release at Priest Rapids and Turtle Rock State Fish Hatcheries (SFH); and (d) steelhead sampled before release at Dworshak National Fish Hatchery (NFH) and Irrigon SFH. Data are listed in Appendices A.1, A.2, and A.3. 


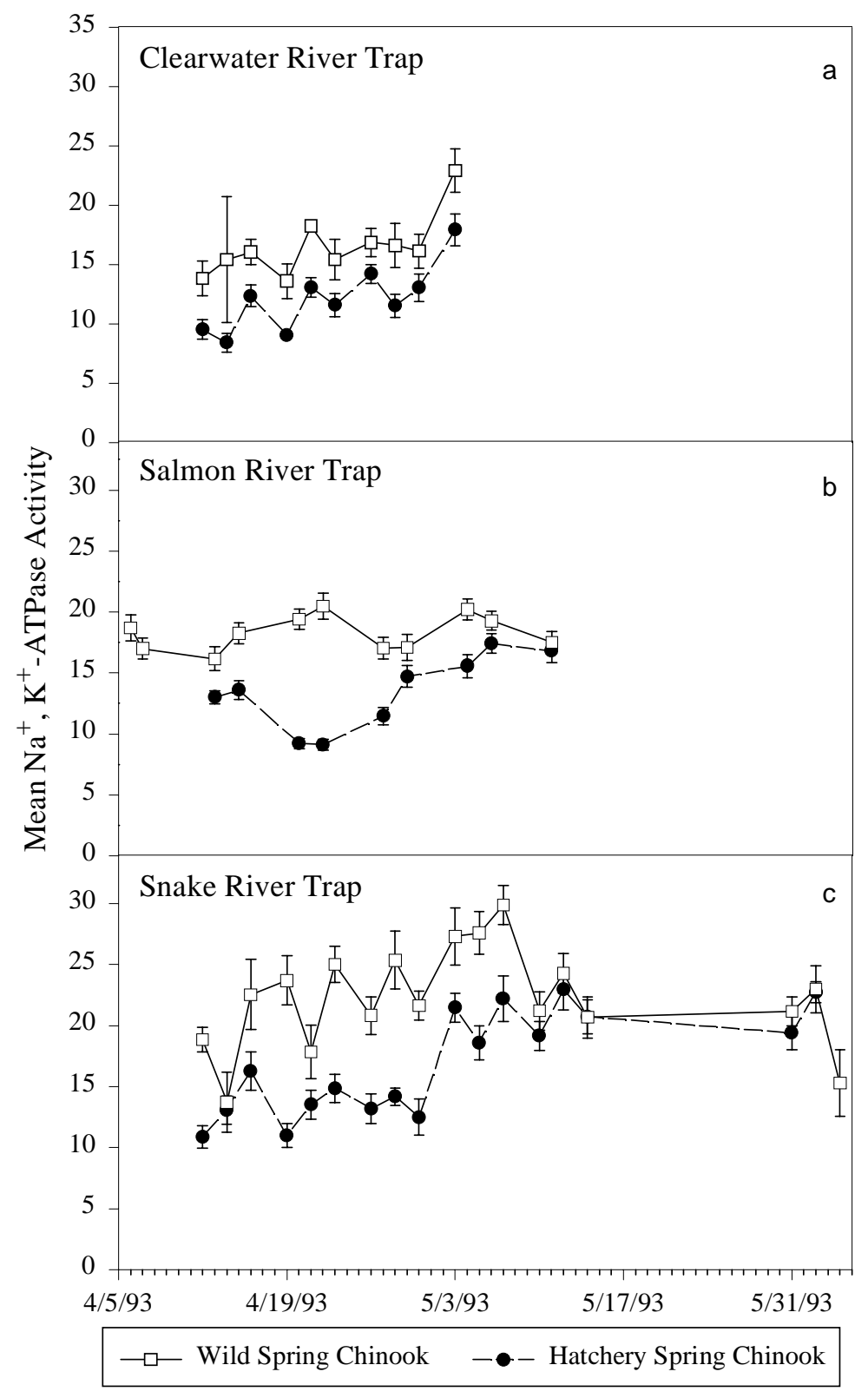

Figure 2. Mean $( \pm \mathrm{SE})$ gill $\mathrm{Na}^{+}, \mathrm{K}^{+}$-ATPase activity $\left(\mu \mathrm{mol} \mathrm{P}_{\mathrm{i}} \cdot \mathrm{mg}\right.$ protein $\left.{ }^{-1} \cdot \mathrm{h}^{-1}\right)$ of wild and hatchery yearling chinook salmon collected during migration in 1993 at (a) the Clearwater River Trap, (b) the Salmon River Trap, and (c) the Snake River Trap. Data are listed in Appendices B.1 and C. 


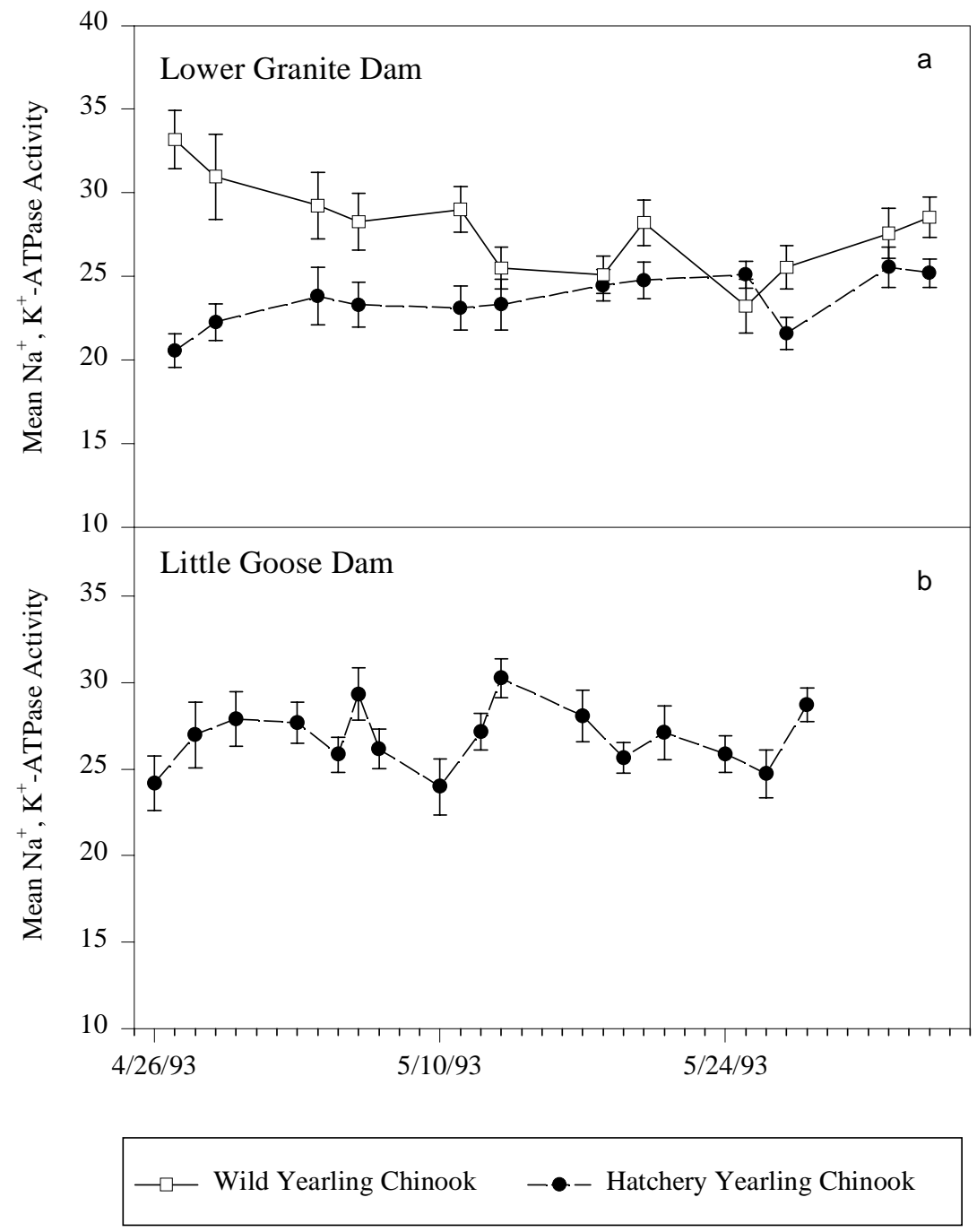

Figure 3. Mean $( \pm \mathrm{SE})$ gill $\mathrm{Na}^{+}, \mathrm{K}^{+}$-ATPase activity $\left(\mu \mathrm{mol} \mathrm{P}_{\mathrm{i}} \cdot \mathrm{mg}\right.$ protein $\left.{ }^{-1} \cdot \mathrm{h}^{-1}\right)$ of wild and hatchery yearling chinook salmon collected during migration in 1993 at (a) Lower Granite Dam and (b) Little Goose Dam on the Snake River. Data are listed in Appendices B.1 and C. 


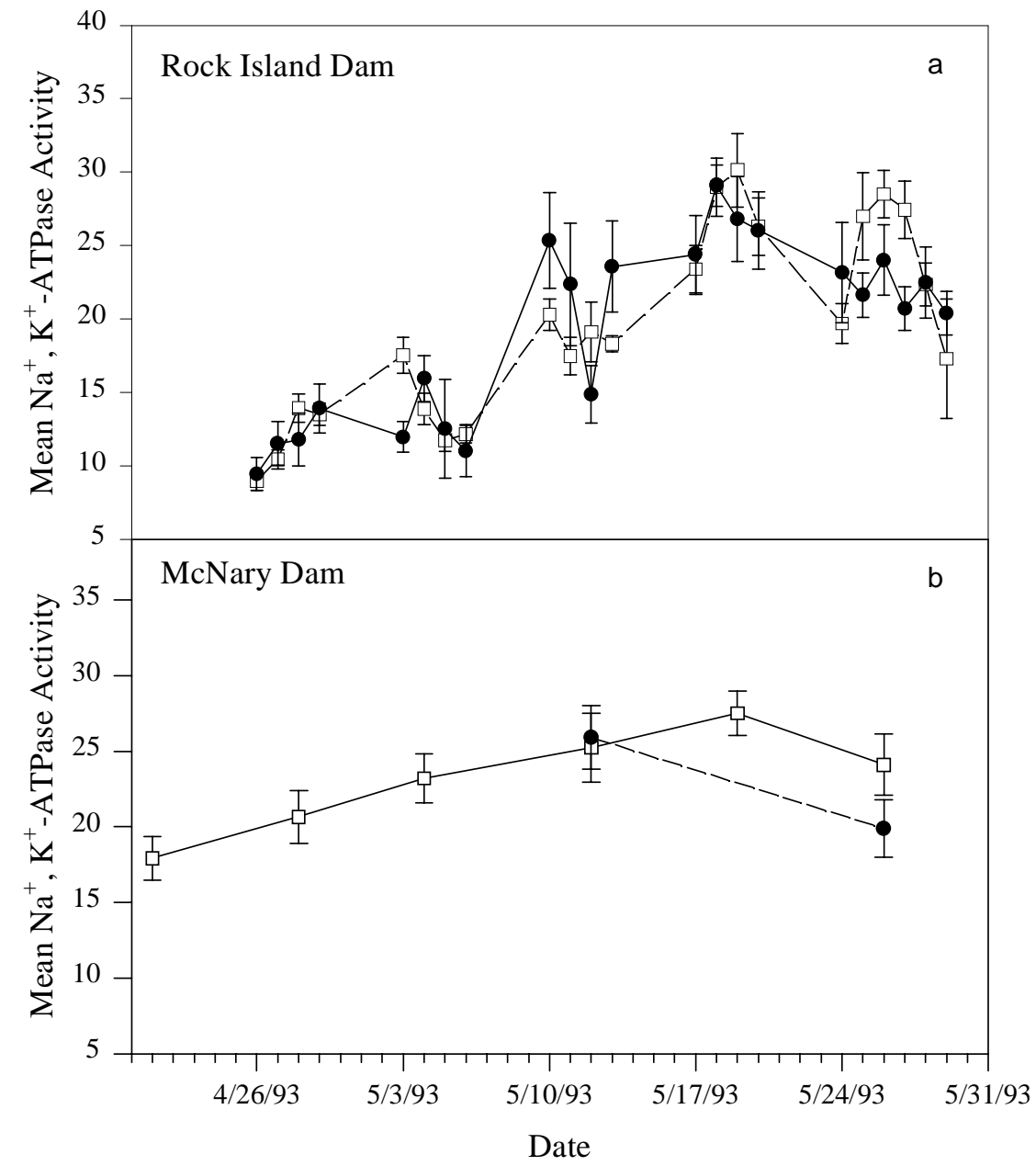

$-\square-$ Intact Adipose Fin $\longrightarrow$ Clipped Adipose Fin

Figure 4. Mean $\left( \pm\right.$ SE) gill $\mathrm{Na}^{+}, \mathrm{K}^{+}$-ATPase activity $\left(\mu \mathrm{mol} \mathrm{P}_{\mathrm{i}} \cdot \mathrm{mg}\right.$ protein $\left.{ }^{-1} \cdot \mathrm{h}^{-1}\right)$ of yearling chinook salmon with intact adipose fins and yearling hatchery chinook salmon (adipose fin-clipped) collected during migration in 1993 at (a) Rock Island Dam and (b) McNary Dam on the Columbia River. Data are listed in Appendix B.2. 


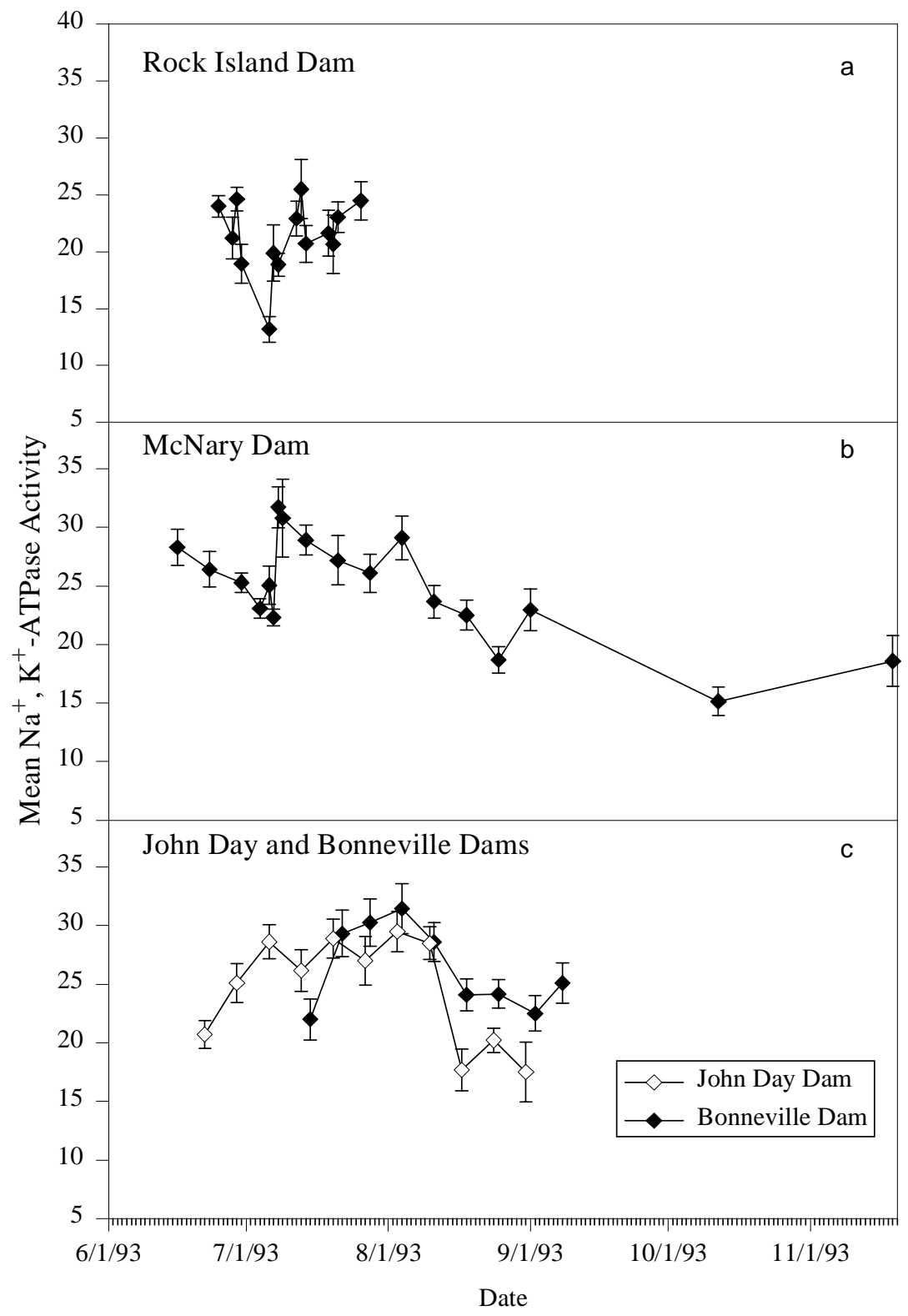

Figure 5. Mean $( \pm \mathrm{SE})$ gill $\mathrm{Na}^{+}, \mathrm{K}^{+}$-ATPase activity $\left(\mu \mathrm{mol} \mathrm{P}_{\mathrm{i}} \cdot \mathrm{mg}\right.$ protein $\left.{ }^{-1} \cdot \mathrm{h}^{-1}\right)$ of subyearling fall chinook salmon collected during migration in 1993 at (a) Rock Island Dam, (b) McNary Dam, and (c) John Day Dam and Bonneville Dam, on the Columbia River. Data are listed in Appendix D. 


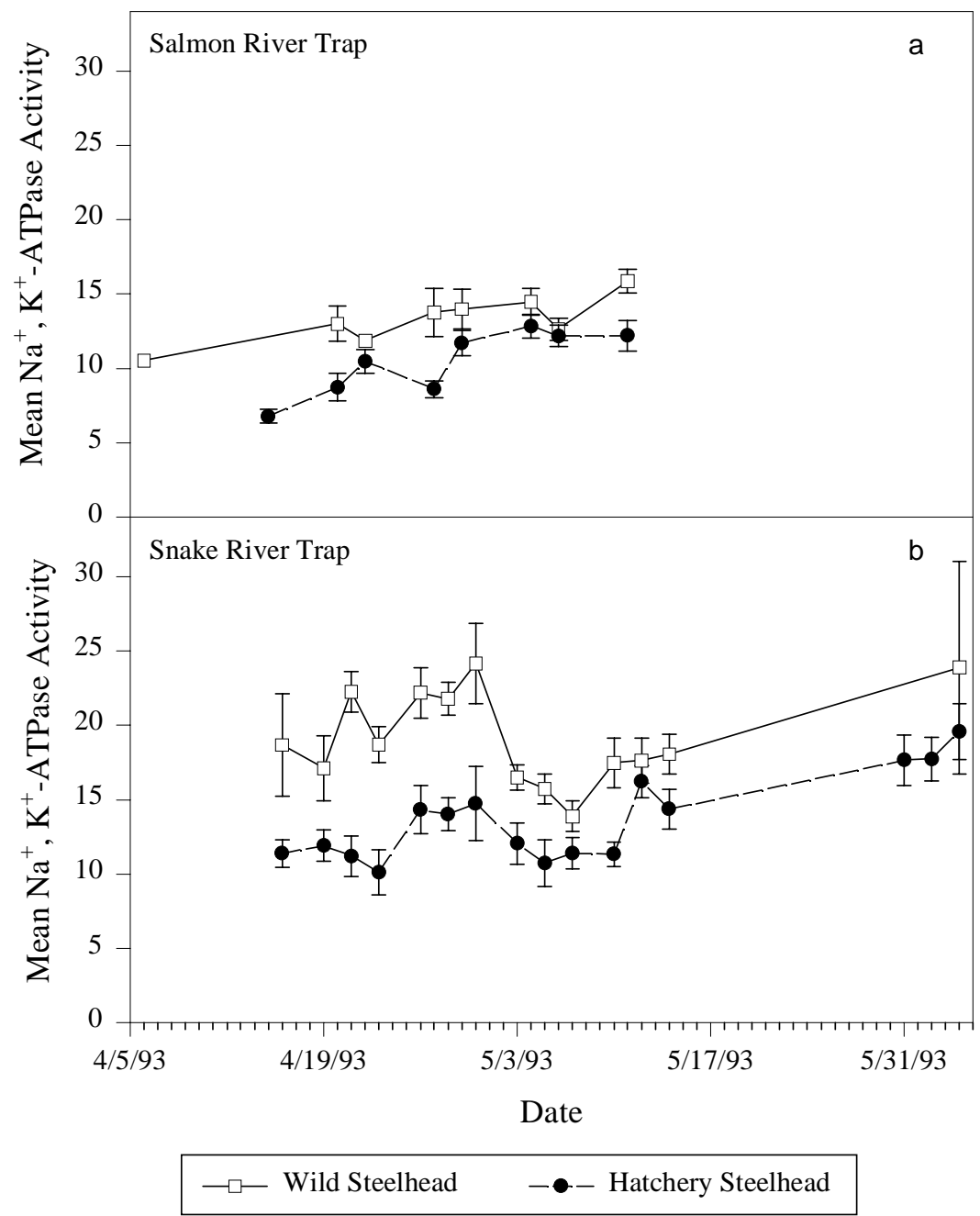

Figure 6. Mean $\left( \pm\right.$ SE) gill $\mathrm{Na}^{+}, \mathrm{K}^{+}$-ATPase activity $\left(\mu \mathrm{mol} \mathrm{P}_{\mathrm{i}} \cdot \mathrm{mg}\right.$ protein $\left.{ }^{-1} \cdot \mathrm{h}^{-1}\right)$ of wild and hatchery steelhead collected during migration in 1993 at (a) the Salmon River Trap and (b) the Snake River Trap. Data are listed in Appendices E and F. 


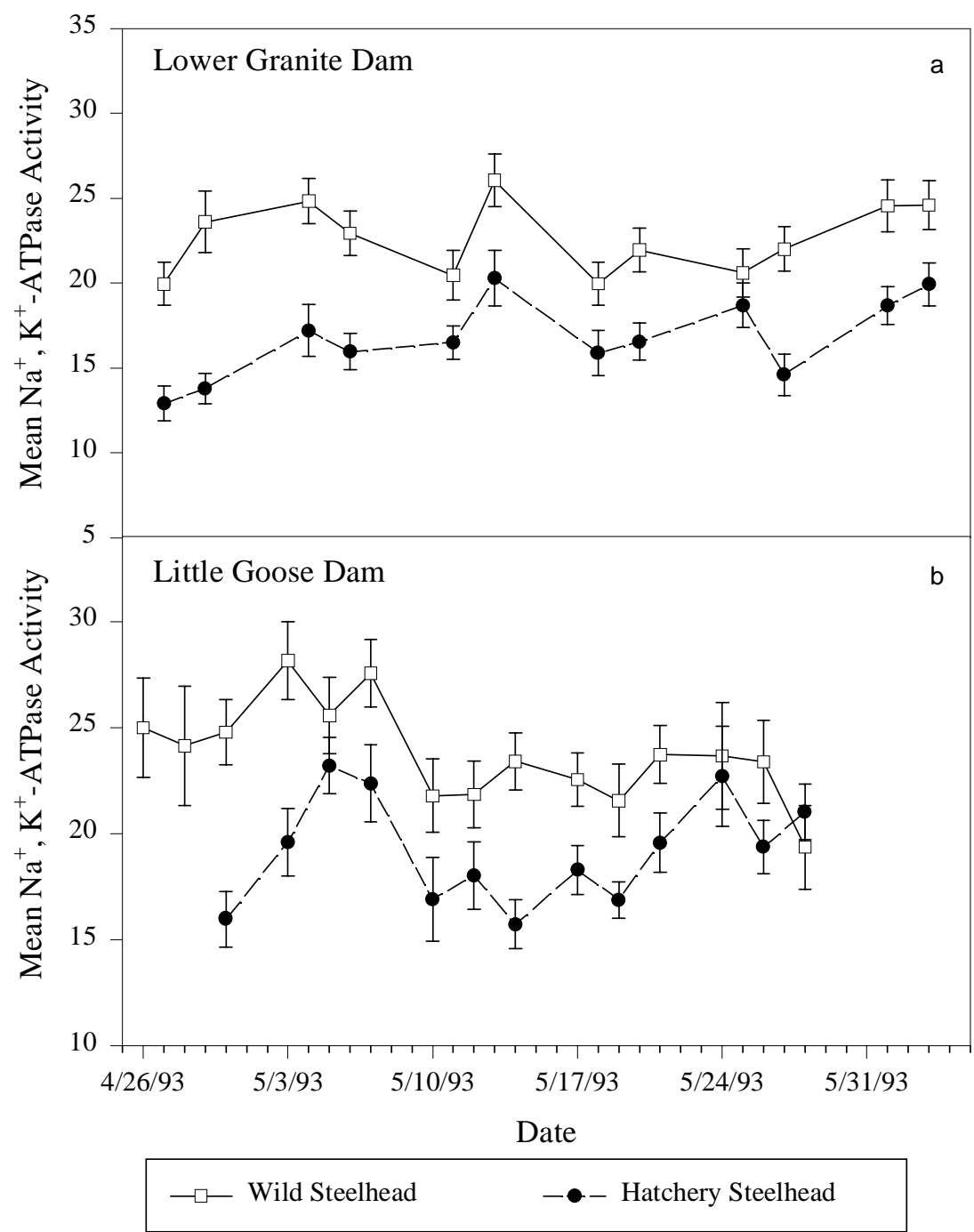

Figure 7. Mean $( \pm \mathrm{SE})$ gill $\mathrm{Na}^{+}, \mathrm{K}^{+}$-ATPase activity $\left(\mu \mathrm{mol} \mathrm{P}_{\mathrm{i}} \cdot \mathrm{mg}\right.$ protein $\left.{ }^{-1} \cdot \mathrm{h}^{-1}\right)$ of wild and hatchery steelhead collected during migration in 1993 at (a) Lower Granite Dam, and (b) Little Goose Dam on the Snake River. Data are listed in Appendices E and F. 


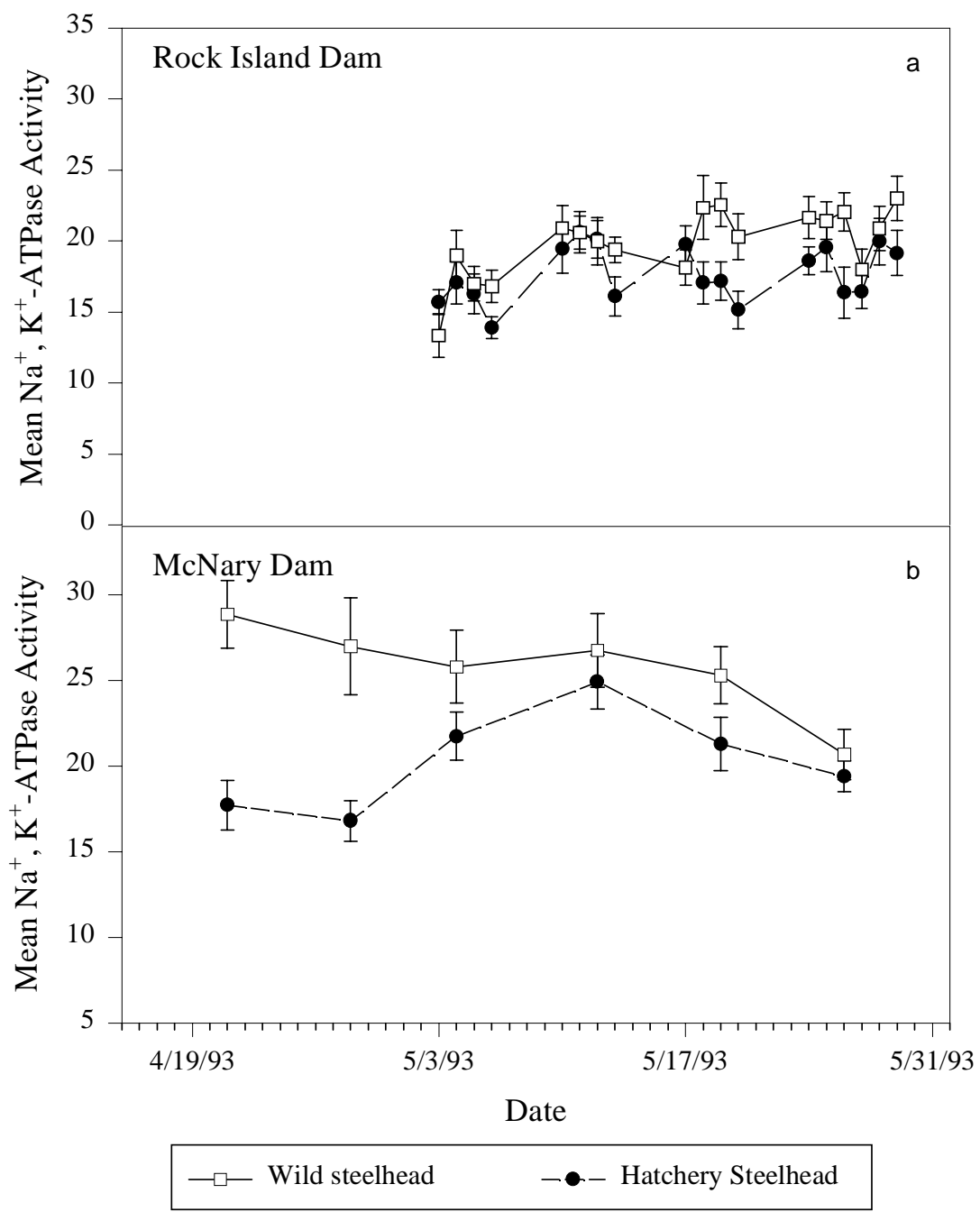

Figure 8. Mean $\left( \pm\right.$ SE) gill $\mathrm{Na}^{+}, \mathrm{K}^{+}$-ATPase activity $\left(\mu \mathrm{mol} \mathrm{P}_{\mathrm{i}} \cdot \mathrm{mg} \operatorname{protein}^{-1} \cdot \mathrm{h}^{-1}\right)$ of wild and hatchery steelhead collected during migration in 1993 at (a) Rock Island Dam and (b) McNary Dam on the Columbia River. Data are listed in Appendices E and F. 


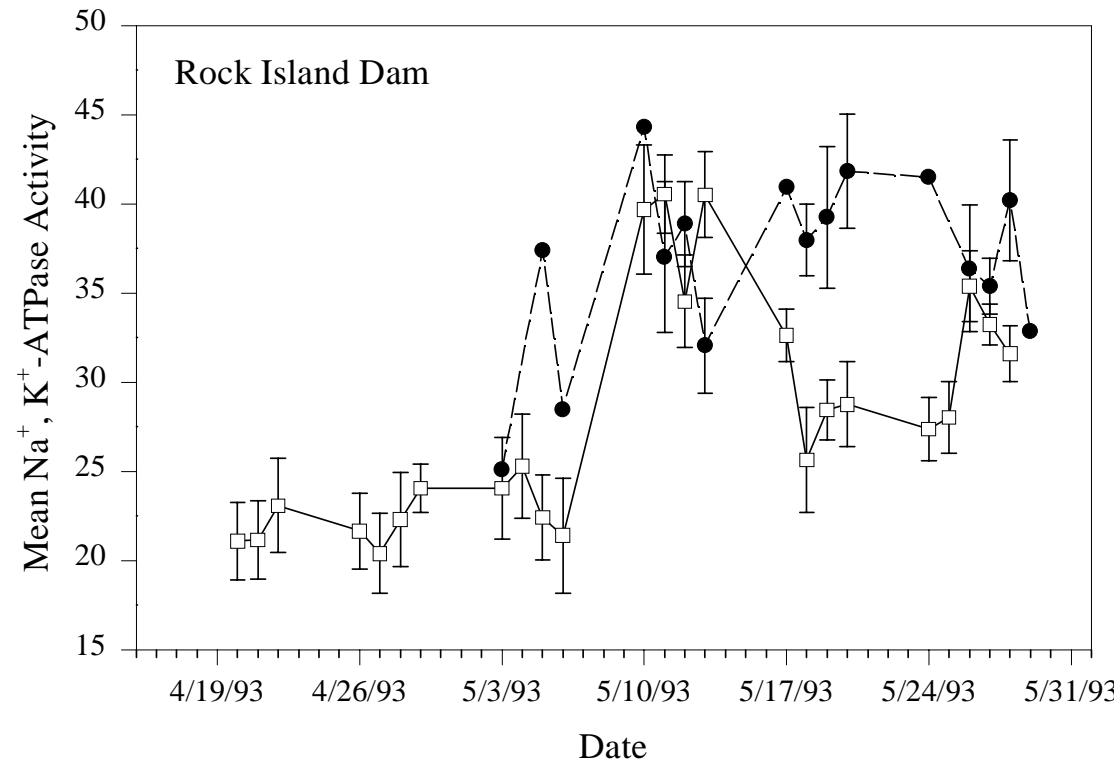

$\neg-$ Wild Sockeye Salmon $\quad-$ - Hatchery Sockeye Salmon

Figure 9. Mean $\left( \pm\right.$ SE) gill $\mathrm{Na}^{+}, \mathrm{K}^{+}$-ATPase activity $\left(\mu \mathrm{mol} \mathrm{P}_{\mathrm{i}} \cdot \mathrm{mg}\right.$ protein $\left.{ }^{-1} \cdot \mathrm{h}^{-1}\right)$ of wild and hatchery sockeye salmon collected during migration in 1993 at Rock Island Dam on the Columbia River. Data are listed in Appendices G.1 and G.2. 

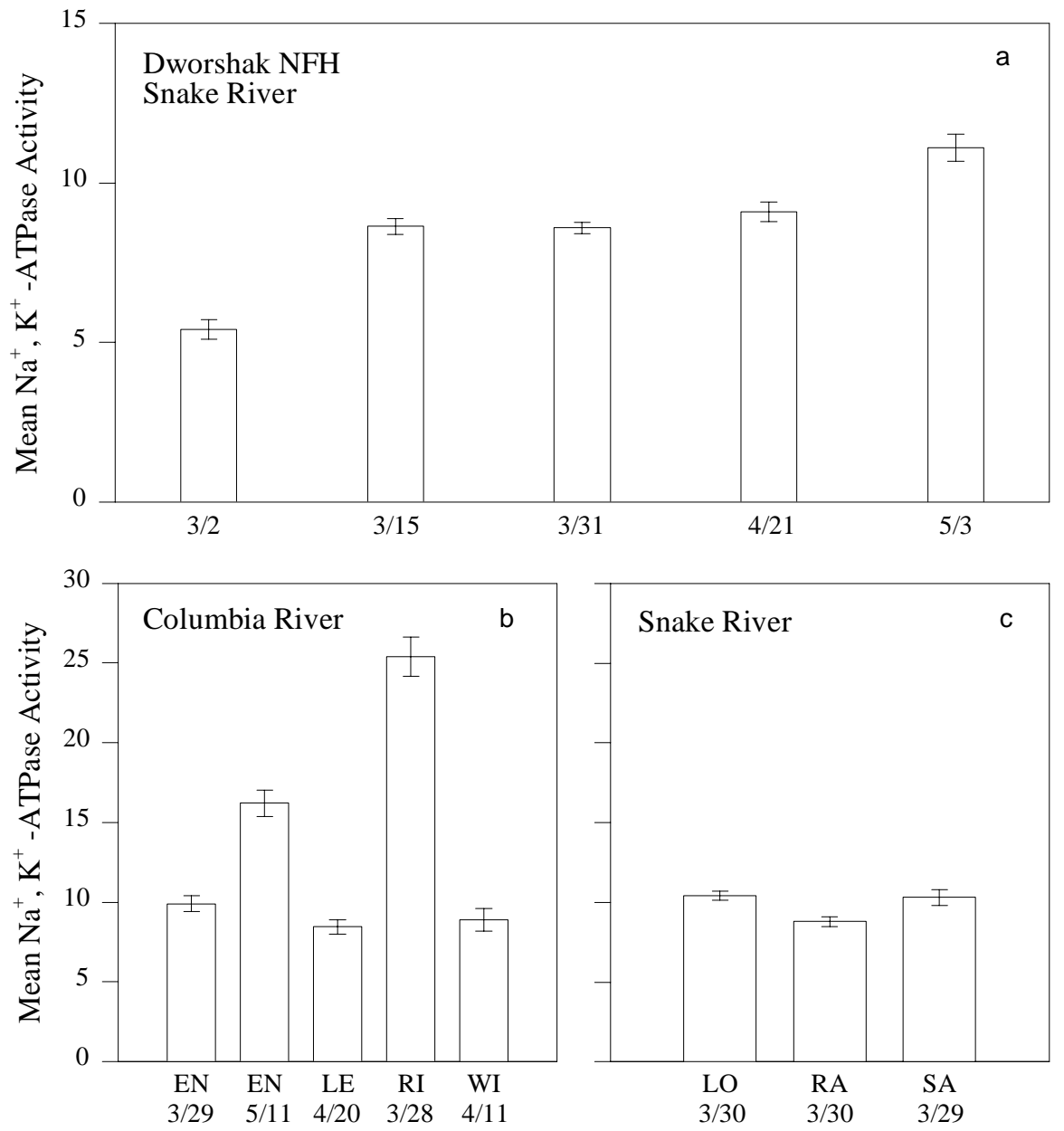

$$
\begin{aligned}
& \text { EN - Entiat NFH WI - Winthrop NFH } \\
& \text { LE - Leavenworth NFH } \\
& \text { RI - Ringold SFH }
\end{aligned}
$$

LO - Lookingglass SFH

RA - Rapid River SFH

SA - Sawtooth SFH

Figure 10. Mean $( \pm \mathrm{SE})$ gill $\mathrm{Na}^{+}, \mathrm{K}^{+}$-ATPase activity $\left(\mu \mathrm{mol} \mathrm{P}_{\mathrm{i}} \cdot \mathrm{mg}\right.$ protein $\left.{ }^{-1} \cdot \mathrm{h}^{-1}\right)$ of yearling spring chinook salmon sampled before release in 1994 from (a) Dworshak National Fish Hatchery (NFH), (b) Columbia River basin hatcheries, and (c) Snake River basin hatcheries. Data are listed in Appendix H.1. 


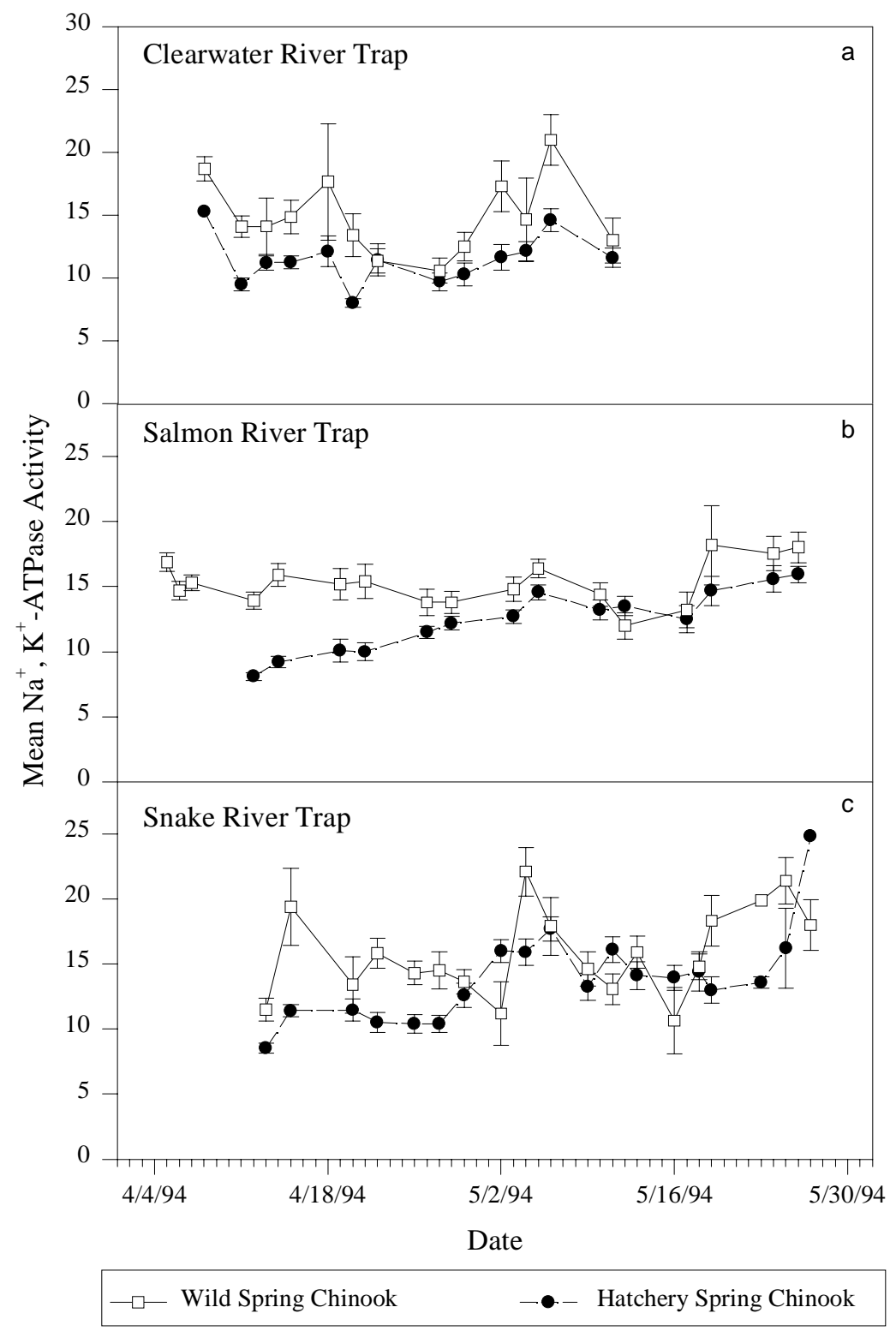

Figure 11. Mean $( \pm \mathrm{SE})$ gill $\mathrm{Na}^{+}, \mathrm{K}^{+}$-ATPase activity $\left(\mu \mathrm{mol} \mathrm{P}_{\mathrm{i}} \cdot \mathrm{mg}\right.$ protein $\left.{ }^{-1} \cdot \mathrm{h}^{-1}\right)$ of wild and hatchery yearling chinook salmon collected during migration in 1994 at (a) the Clearwater River Trap, (b) the Salmon River Trap, and (c) the Snake River Trap. Data are listed in Appendices I.1 and J. 


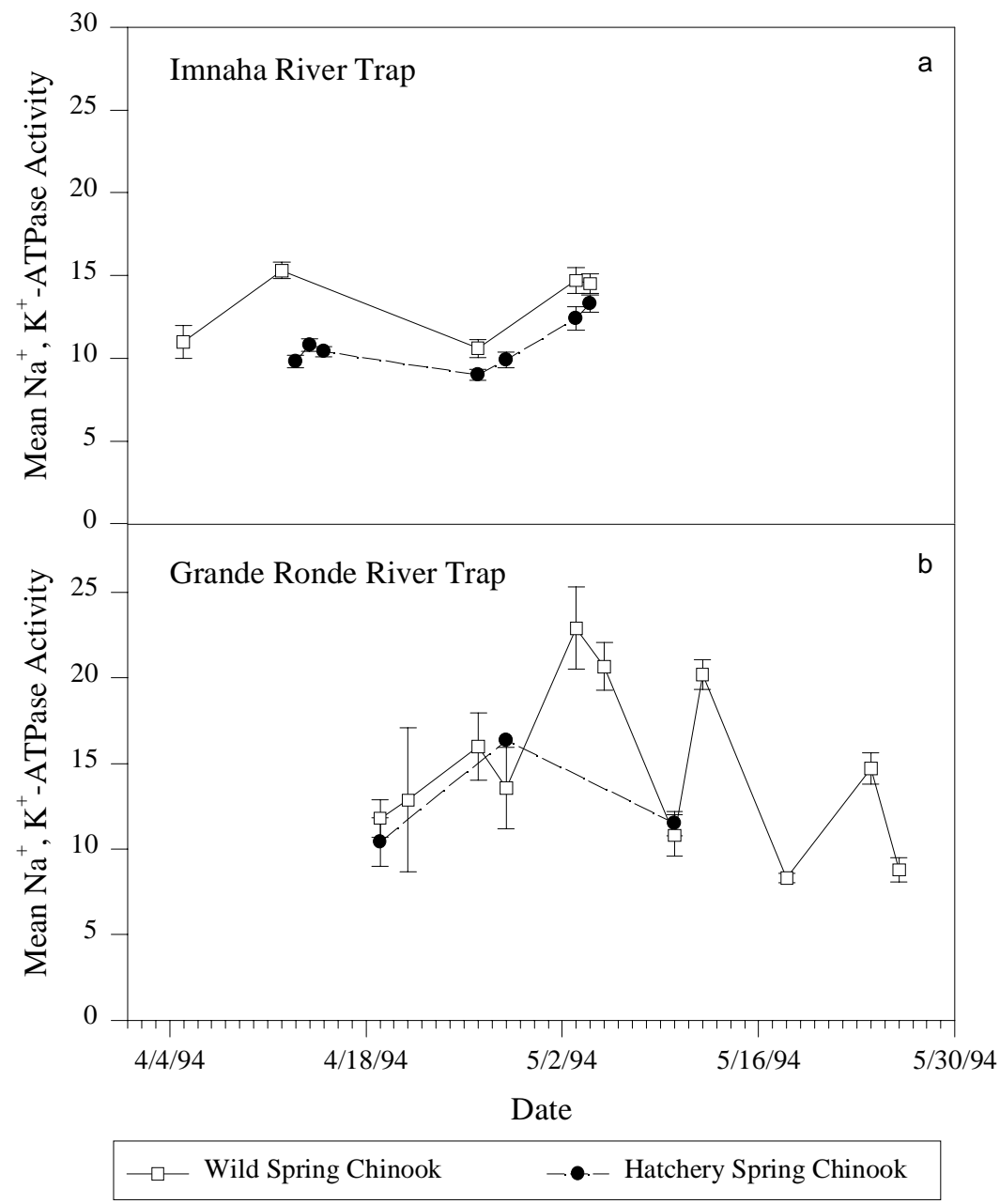

Figure 12. Mean $\left( \pm\right.$ SE) gill $\mathrm{Na}^{+}, \mathrm{K}^{+}$-ATPase activity $\left(\mu \mathrm{mol} \mathrm{P}_{\mathrm{i}} \cdot \mathrm{mg}\right.$ protein $\left.{ }^{-1} \cdot \mathrm{h}^{-1}\right)$ of wild and hatchery yearling chinook salmon collected during migration in 1994 at (a) the Imnaha River Trap and (b) the Grande Ronde River Trap. Data are listed in Appendices I.1 and J. 


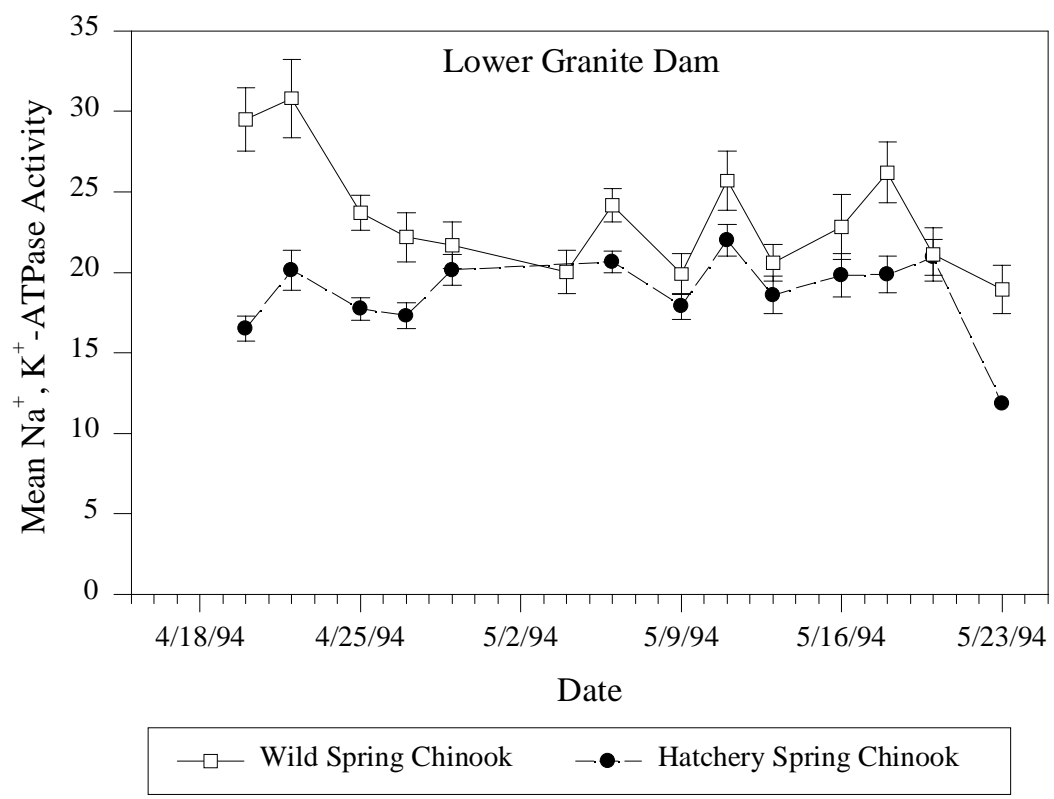

Figure 13. Mean $\left( \pm\right.$ SE) gill $\mathrm{Na}^{+}, \mathrm{K}^{+}$-ATPase activity $\left(\mu \mathrm{mol} \mathrm{P}_{\mathrm{i}} \cdot \mathrm{mg}_{\text {protein }}{ }^{-1} \cdot \mathrm{h}^{-1}\right)$ of wild and hatchery yearling chinook salmon collected during migration in 1994 at Lower Granite Dam on the Snake River. Data are listed in Appendices I.1 and J. 


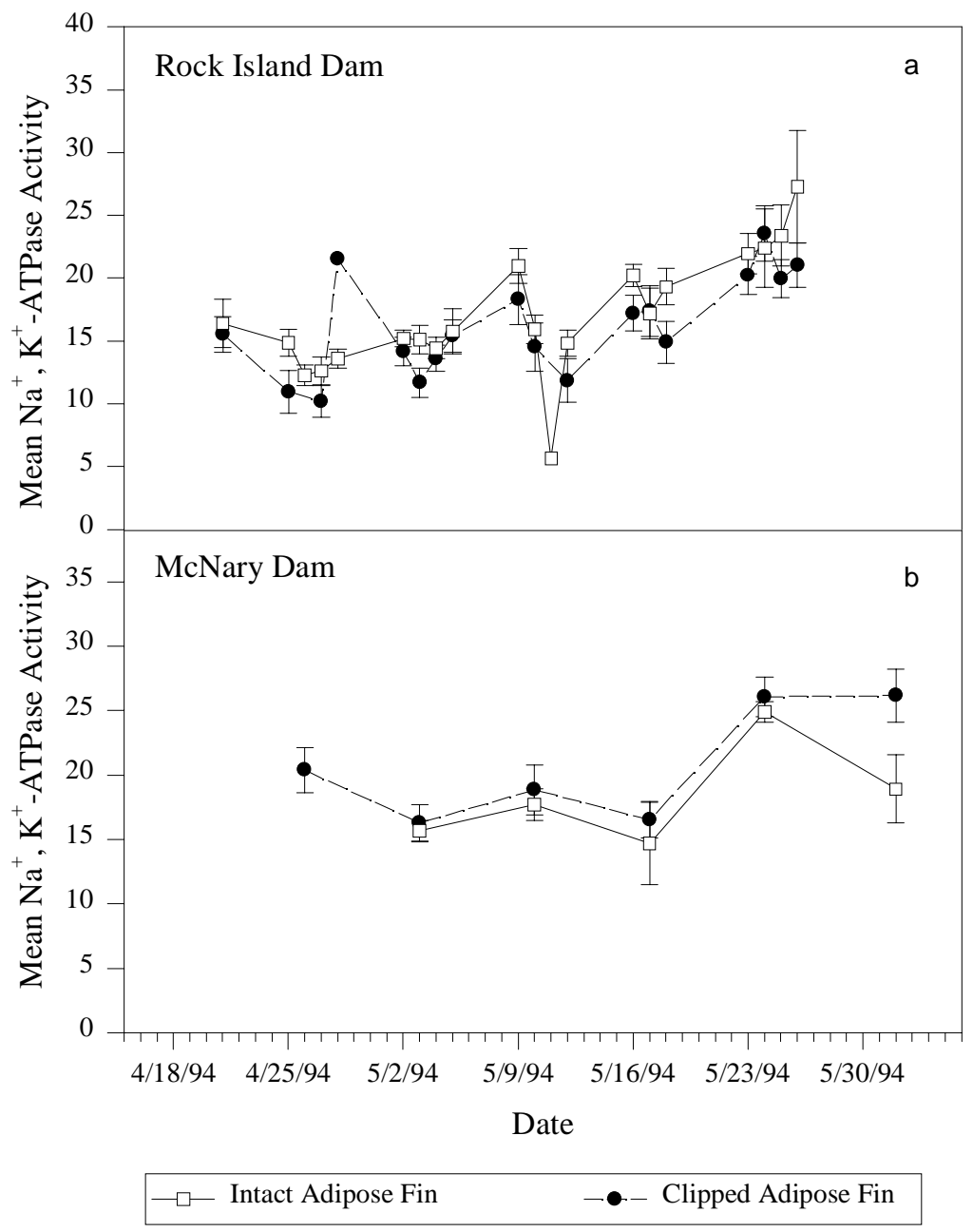

Figure 14. Mean $\left( \pm\right.$ SE) gill $\mathrm{Na}^{+}, \mathrm{K}^{+}$-ATPase activity $\left(\mu \mathrm{mol} \mathrm{P}_{\mathrm{i}} \cdot \mathrm{mg}\right.$ protein $\left.{ }^{-1} \cdot \mathrm{h}^{-1}\right)$ of yearling chinook salmon with intact adipose fins and hatchery yearling chinook salmon (adipose fin-clipped) collected during migration in 1994 at (a) Rock Island Dam and (b) McNary Dam on the Columbia River. Data are listed in Appendices I.1 and I.2. 


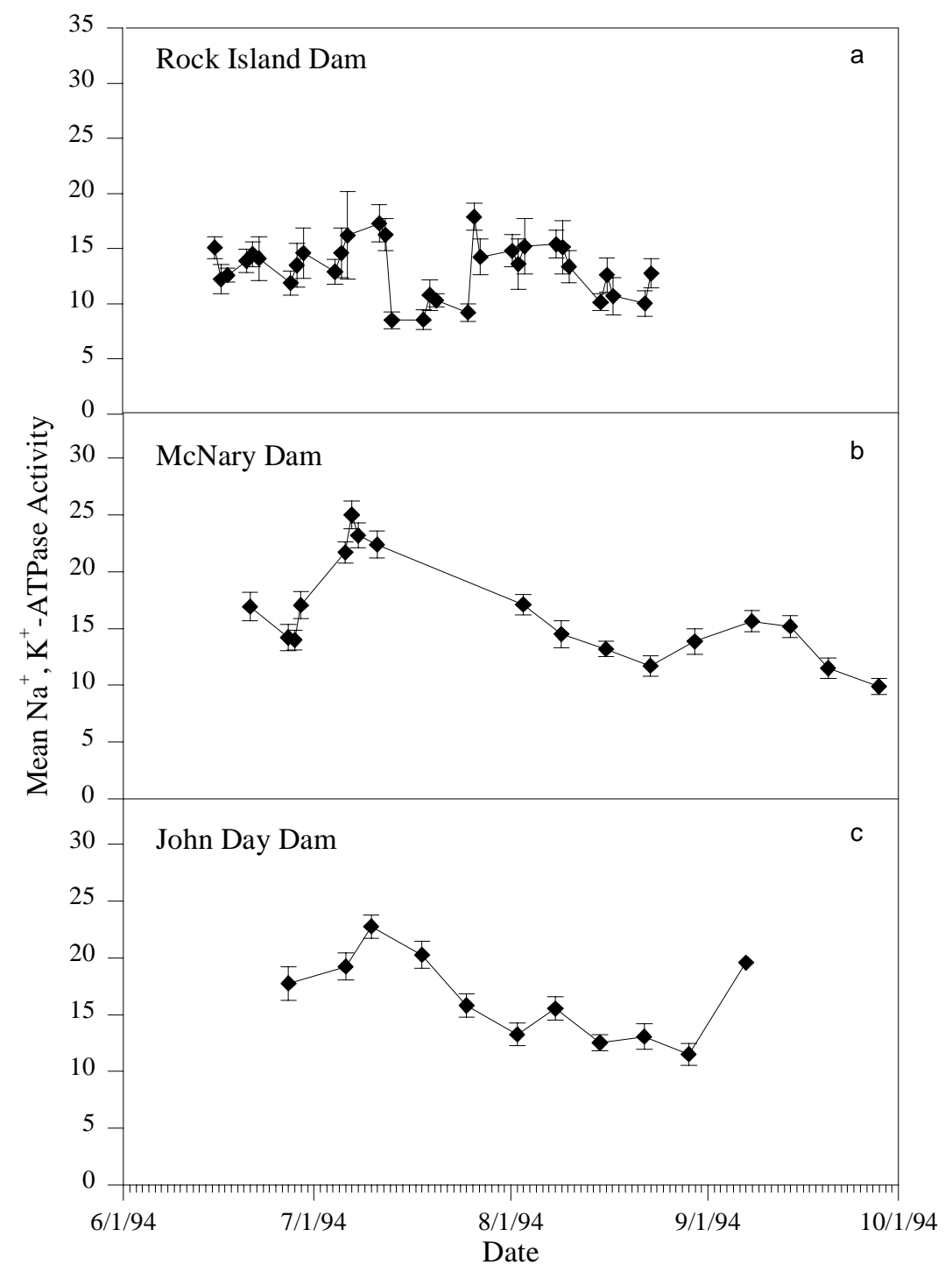

Figure 15. Mean $\left( \pm\right.$ SE) gill $\mathrm{Na}^{+}, \mathrm{K}^{+}$-ATPase activity $\left(\mu \mathrm{mol} \mathrm{P}_{\mathrm{i}} \cdot \mathrm{mg}\right.$ protein $\left.{ }^{-1} \cdot \mathrm{h}^{-1}\right)$ of subyearling fall chinook salmon collected during migration in 1994 at (a) Rock Island Dam, (b) McNary Dam, and (c) John Day Dam on the Columbia River. Data are listed in Appendix K. 


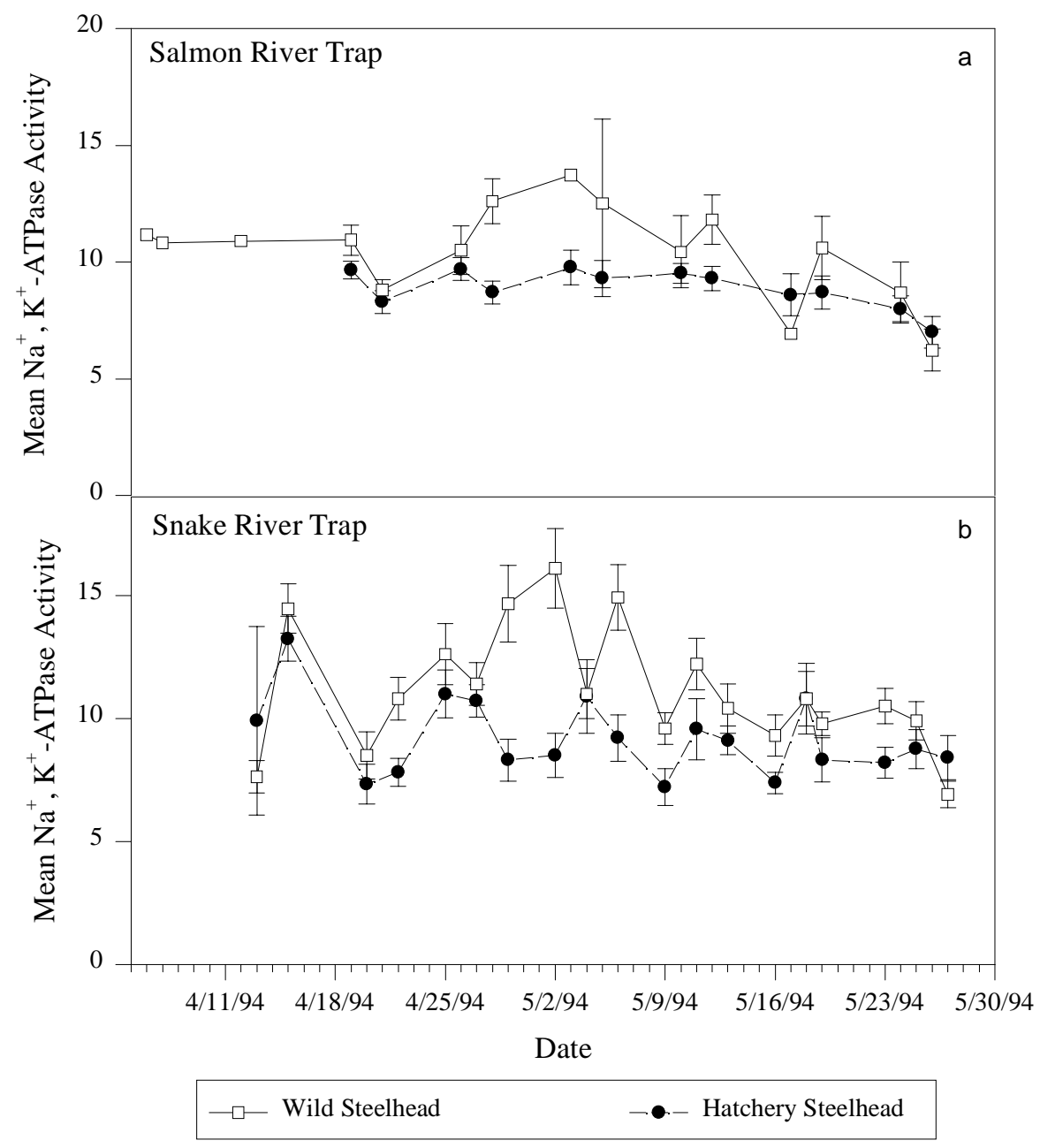

Figure 16. Mean $( \pm \mathrm{SE})$ gill $\mathrm{Na}^{+}, \mathrm{K}^{+}$-ATPase activity $\left(\mu \mathrm{mol} \mathrm{P}_{\mathrm{i}} \cdot \mathrm{mg}\right.$ protein $\left.{ }^{-1} \cdot \mathrm{h}^{-1}\right)$ of wild and hatchery steelhead collected during migration in 1994 at (a) Snake River Trap and (b) Salmon River Trap. Data are listed in Appendices L and M. 


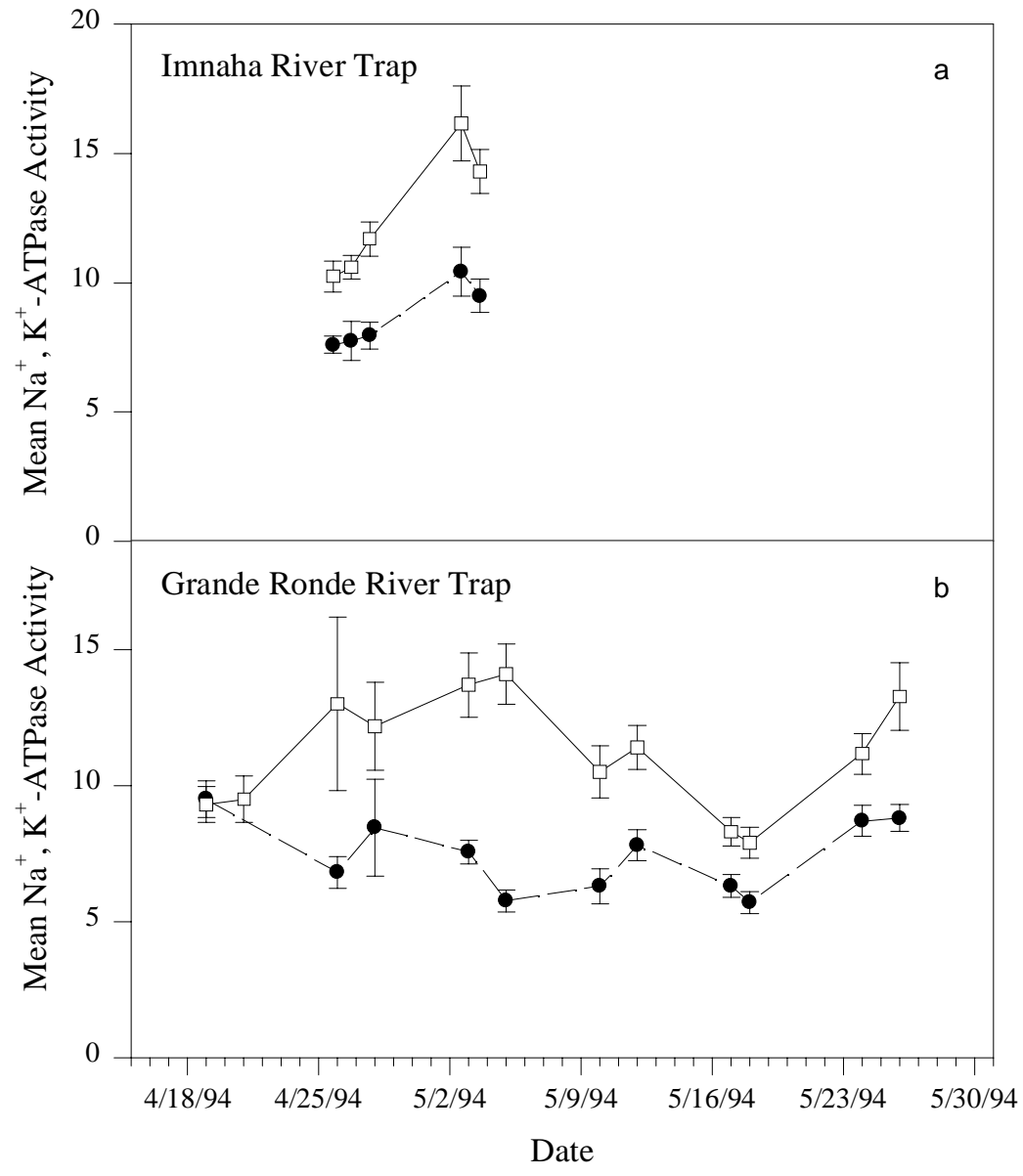

$\multimap$ Wild Steelhead $\quad \multimap$ Hatchery Steelhead

Figure 17. Mean $\left( \pm\right.$ SE) gill $\mathrm{Na}^{+}, \mathrm{K}^{+}$-ATPase activity $\left(\mu \mathrm{mol} \mathrm{P}_{\mathrm{i}} \cdot \mathrm{mg}\right.$ protein $\left.{ }^{-1} \cdot \mathrm{h}^{-1}\right)$ of wild and hatchery steelhead collected during migration in 1994 at (a) the Imnaha River Trap and (b) the Grande Ronde River Trap. Data are listed in Appendices L and M. 


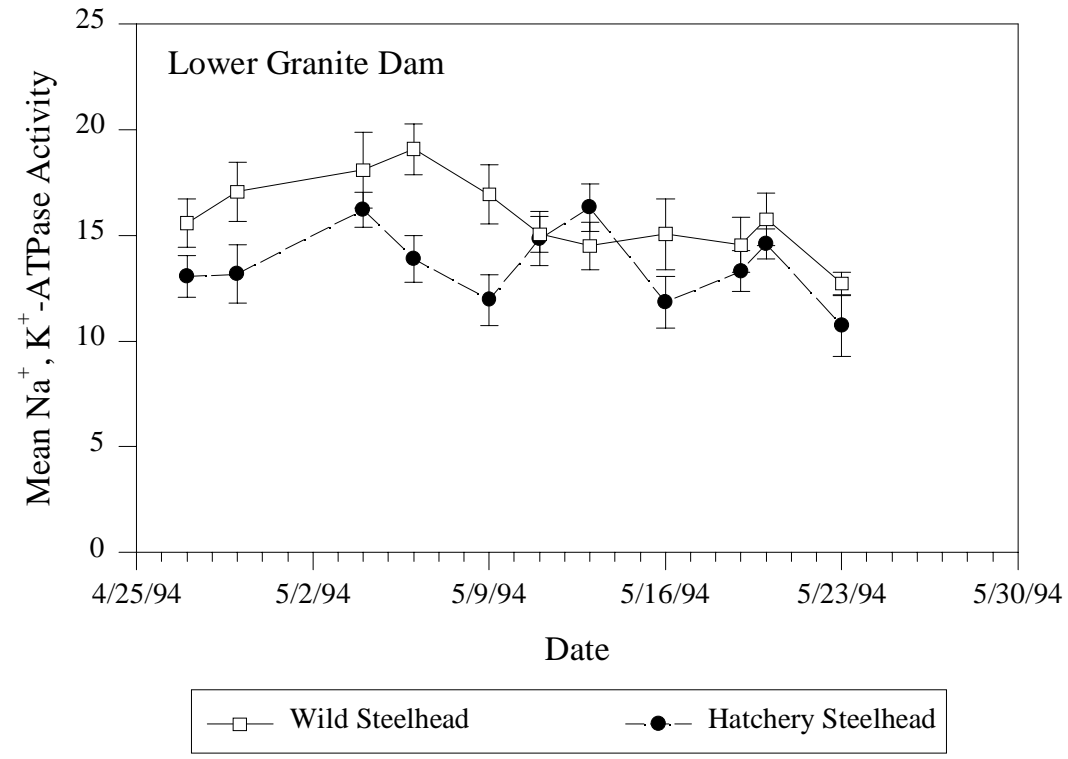

Figure 18. Mean $\left( \pm\right.$ SE) gill $\mathrm{Na}^{+}, \mathrm{K}^{+}$-ATPase activity $\left(\mu \mathrm{mol} \mathrm{P}_{\mathrm{i}} \cdot \mathrm{mg}\right.$ protein $\left.{ }^{-1} \cdot \mathrm{h}^{-1}\right)$ of wild and hatchery steelhead collected during migration in 1994 at Lower Granite Dam on the Snake River. Data are listed in Appendices L and M. 


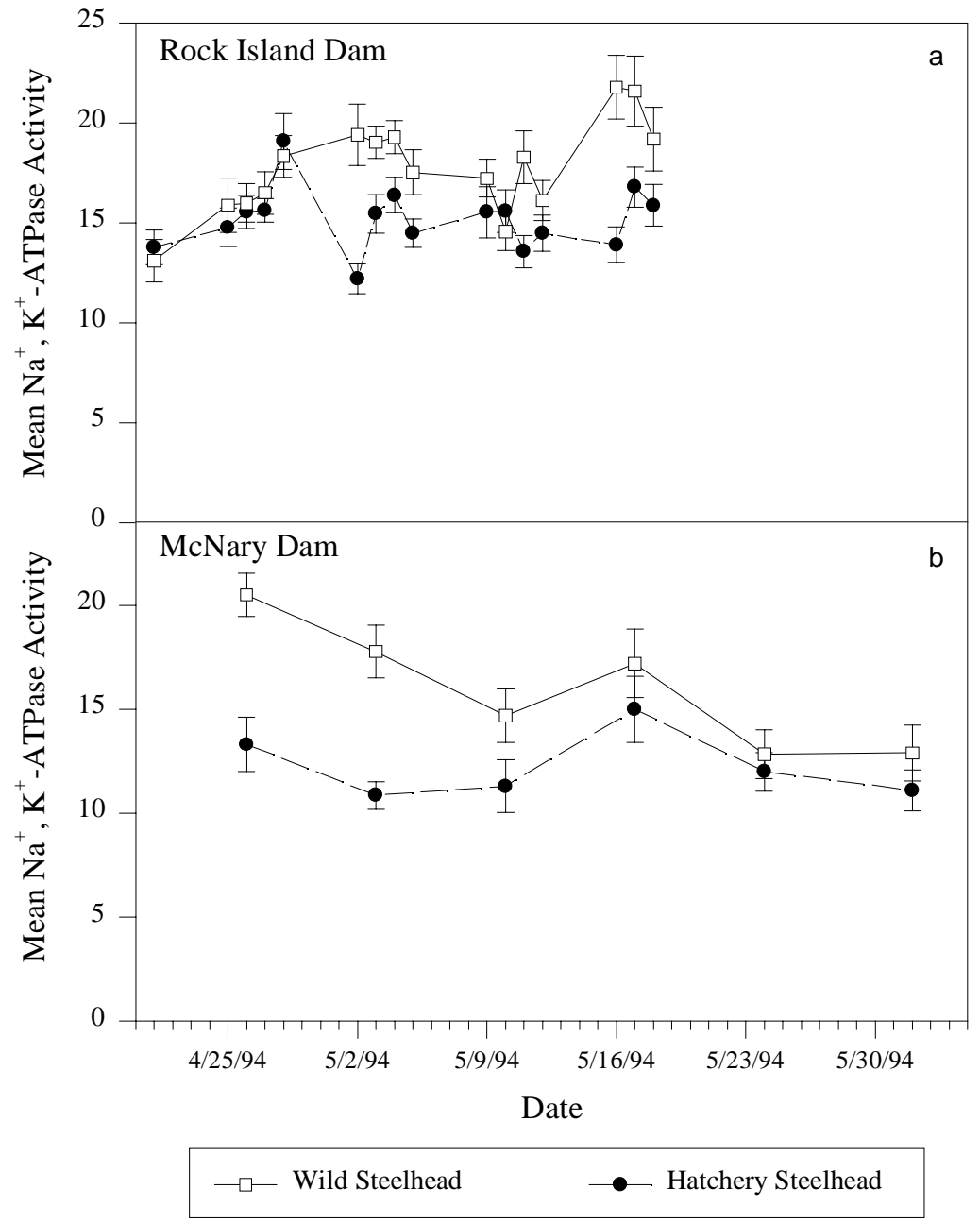

Figure 19. Mean $( \pm \mathrm{SE})$ gill $\mathrm{Na}^{+}, \mathrm{K}^{+}$-ATPase activity $\left(\mu \mathrm{mol} \mathrm{P}_{\mathrm{i}} \cdot \mathrm{mg}_{\text {protein }}{ }^{-1} \cdot \mathrm{h}^{-1}\right)$ of wild and hatchery steelhead collected during migration in 1994 at (a) Rock Island Dam and (b) McNary Dam on the Columbia River. Data are listed in Appendices L and $\mathrm{M}$. 


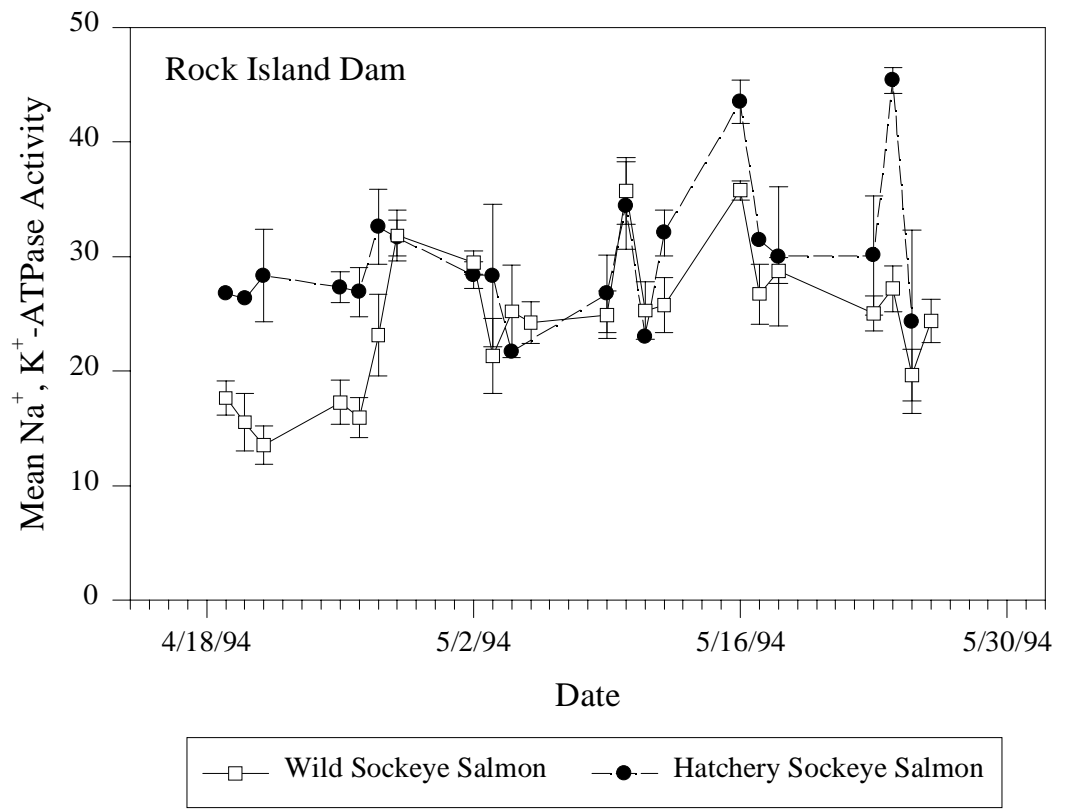

Figure 20. Mean $\left( \pm\right.$ SE) gill $\mathrm{Na}^{+}, \mathrm{K}^{+}$-ATPase activity $\left(\mu \mathrm{mol} \mathrm{P}_{\mathrm{i}} \cdot \mathrm{mg}\right.$ protein $\left.{ }^{-1} \cdot \mathrm{h}^{-1}\right)$ of wild and hatchery sockeye salmon collected during migration in 1994 at Rock Island Dam on the Columbia River. Data are listed in Appendices N.1 and N.2. 


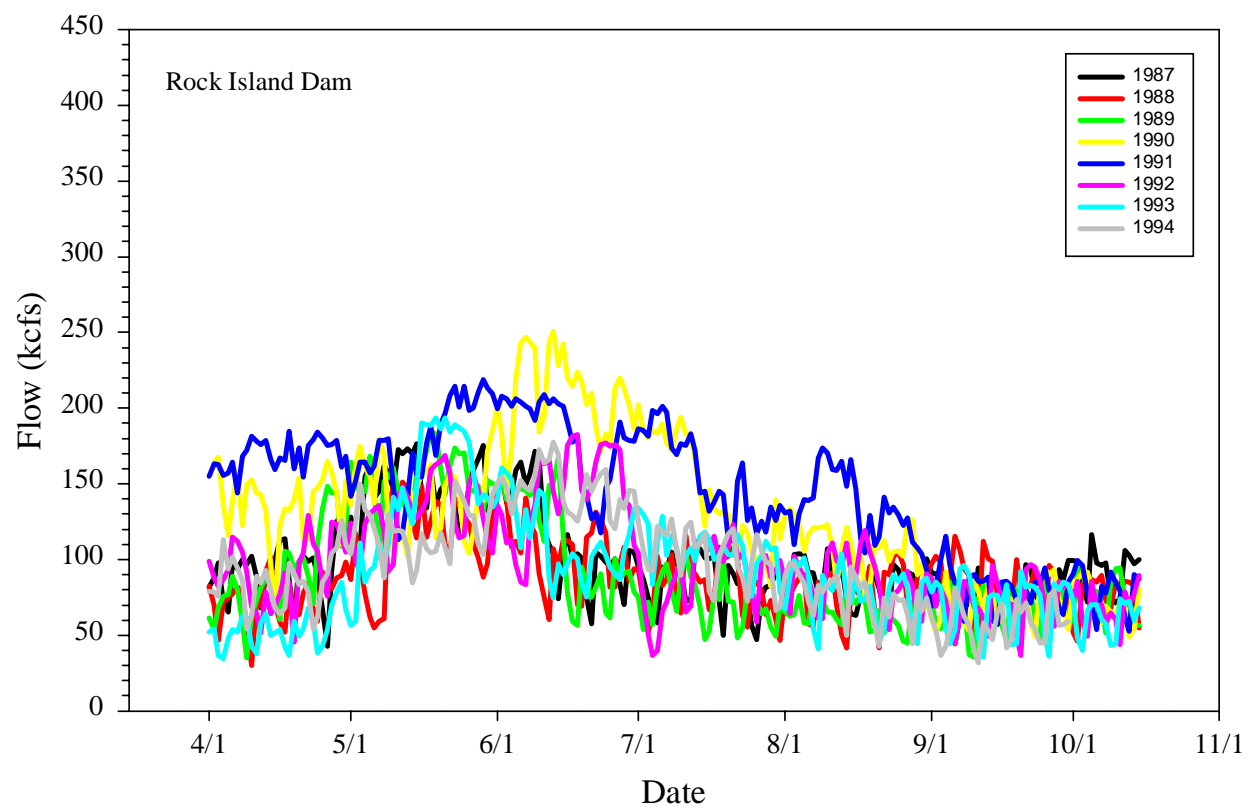

Figure 21. Columbia River flow (kcfs) at Rock Island Dam, April-October, 1987-1994 (Source: U.S. Army Corps of Engineers data, University of Washington 1998).

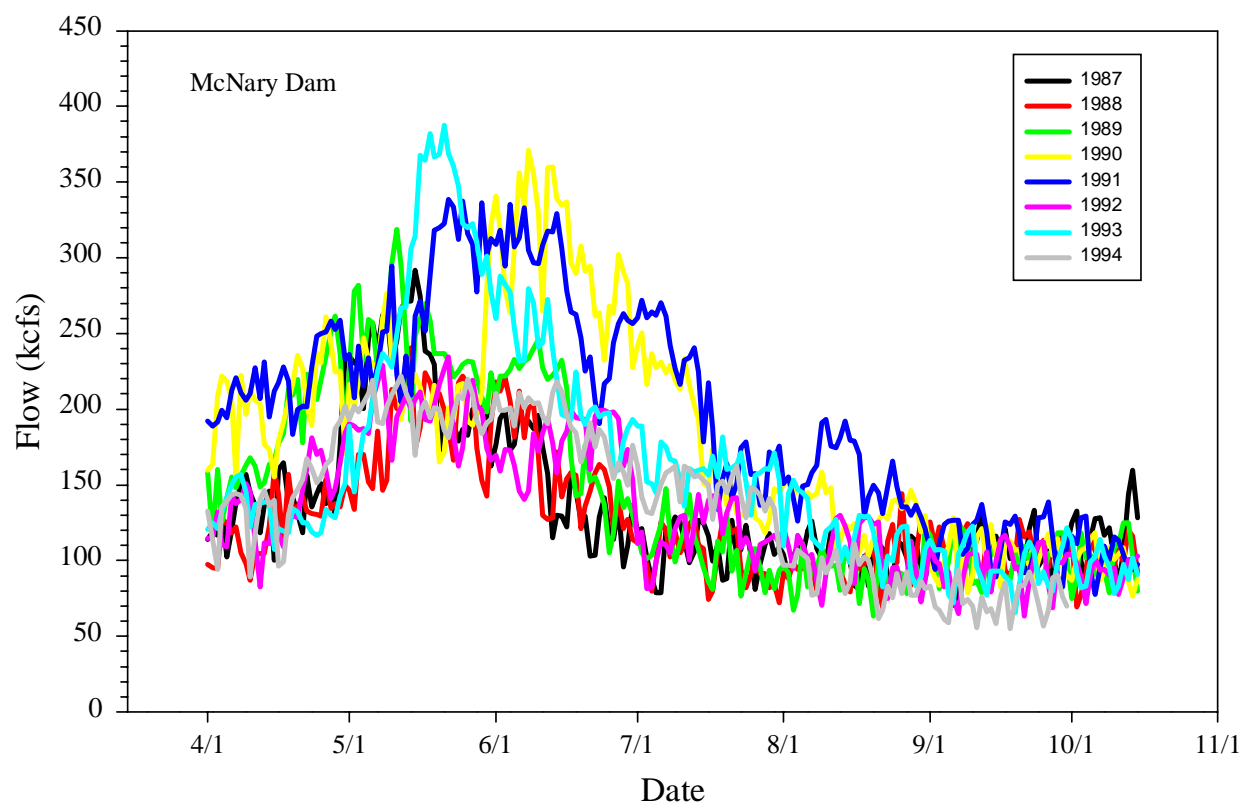

Figure 22. Columbia River flow (kcfs) at McNary Dam, April-October, 1987-1994 (Source: U.S. Army Corps of Engineers data, University of Washington 1998). 


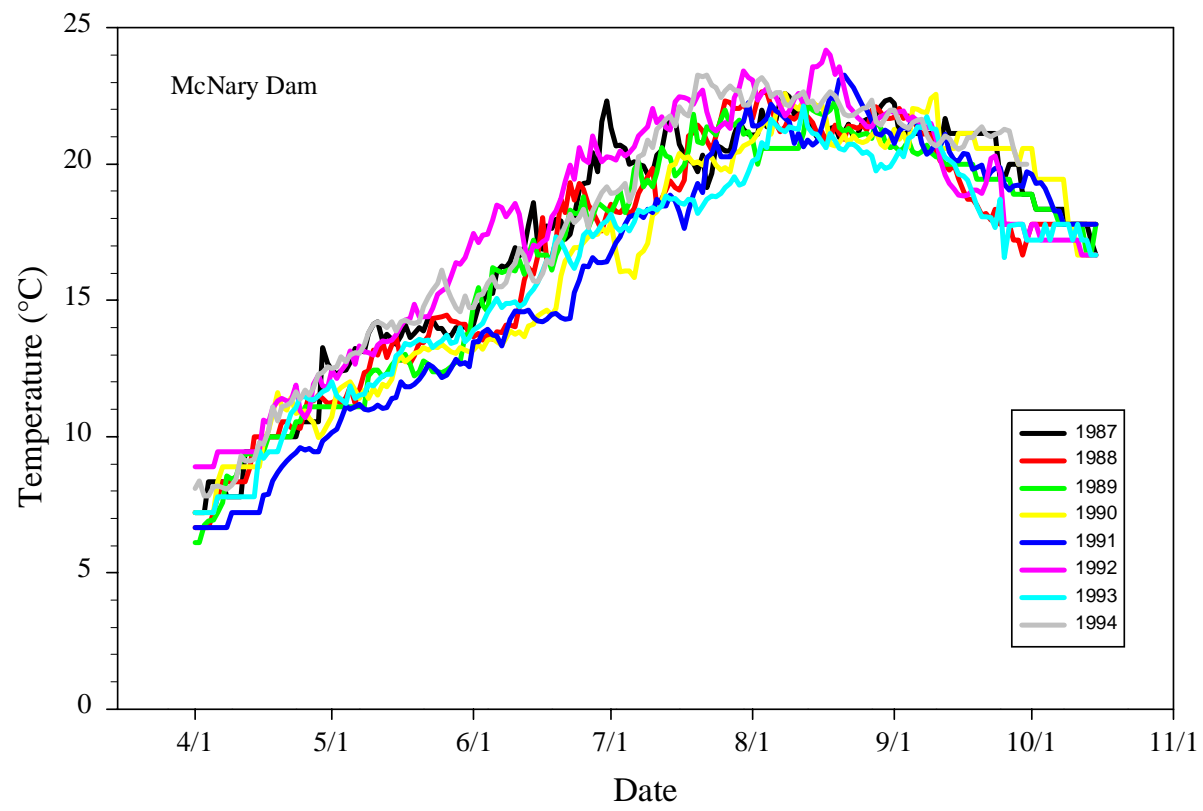

Figure 23. Columbia River temperature $\left({ }^{\circ} \mathrm{C}\right)$ at McNary Dam, April-October, 1987-1994 (Source: U.S. Army Corps of Engineers data, University of Washington 1998).

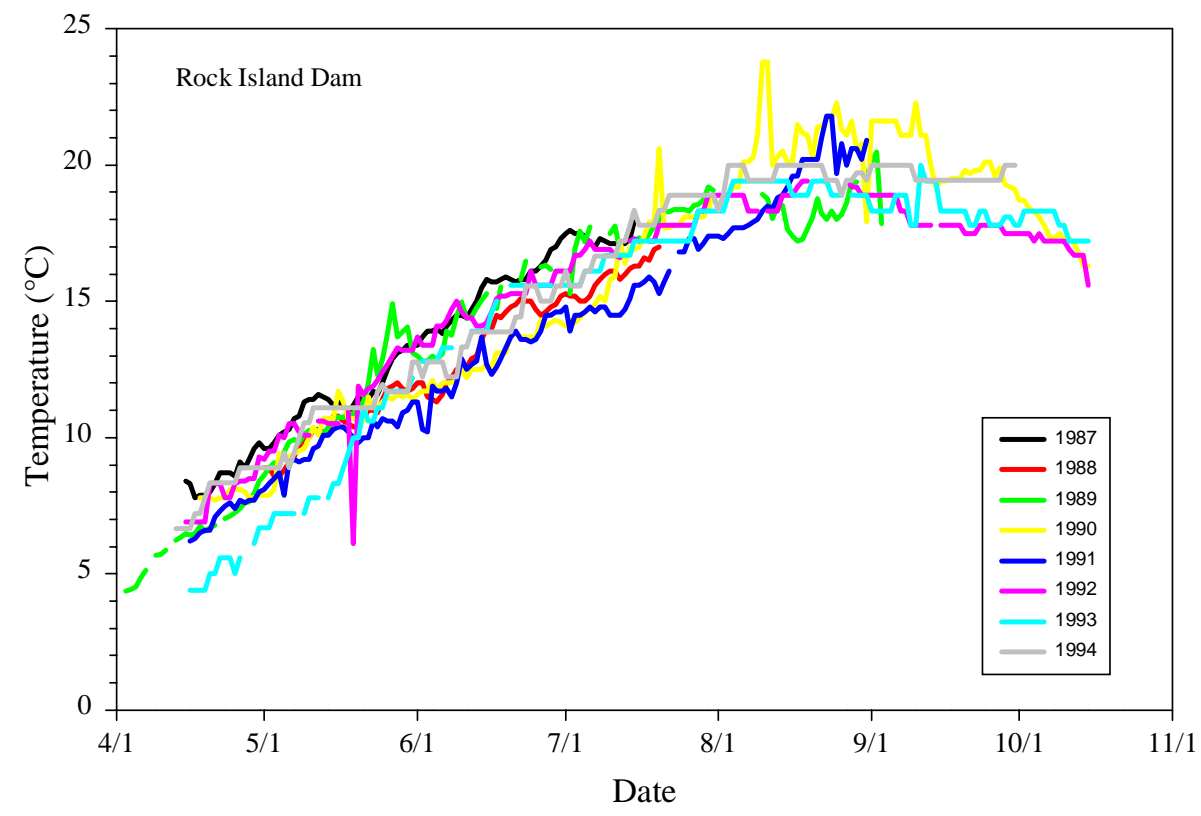

Figure 24. Columbia River temperature $\left({ }^{\circ} \mathrm{C}\right)$ at Rock Island Dam, April-October, 1987-1994 (Sources: U.S. Army Corps of Engineers data, University of Washington 1998; Fish Passage Center, unpublished data). 


\title{
CHAPTER TWO
}

\section{Physiological Measurements in Support of Survival Estimates for Juvenile Salmonids Passing through Dams and Reservoirs}

\author{
Philip V. Haner \\ Alec G. Maule \\ Robin M. Schrock \\ Jack D. Hotchkiss
}

\begin{abstract}
Spring chinook salmon used as part of the National Marine Fisheries Service Lower Granite Survival Study in 1993 and 1994 were sampled at sites on the Snake River to determine whether physiological or morphological differences between groups from multiple releases at a sample site related to differences in survival. Fish were purse-seined at Lower Granite Reservoir and sampled from the collection facilities at Lower Granite and Little Goose dams. Information on gill sodium, potassium-activated adenosine triphosphatase $\left(\mathrm{Na}^{+}, \mathrm{K}^{+}\right.$-ATPase) activity, condition factor (Kfactor), plasma cortisol, and prevalence of bacterial kidney disease and other diseases, were tested for differences between release groups within sample sites and between sites. Results showed that fish collected at dams were more stressed than fish collected from the reservoirs. Survival did not appear to be affected by differences in physiological attributes of salmonids in release groups.
\end{abstract}

\section{INTRODUCTION}

In the spring of 1993 and 1994, we monitored the health and condition of fish that were captured, passive integrated transponder (PIT)-tagged, and released as part of the National Marine Fisheries Service (NMFS) Lower Granite Survival Study (Iwamoto et al. 1994; Muir et al. 1995). In 1993, hatchery spring chinook salmon (Oncorhynchus tshawytscha) were collected at Lower Granite Reservoir, Lower Granite Dam, and Little Goose Dam, PIT-tagged, and released after a 24-hour recovery period. All hatchery chinook salmon released into the Snake River were adipose fin-clipped for the first time in 1993, allowing differentiation of wild and hatchery chinook salmon. In 1994, yearling hatchery steelhead (O. mykiss) and hatchery spring chinook salmon were collected in Lower Granite Reservoir, Lower Granite Dam, Little Goose Dam, and Lower Monumental Dam, PIT-tagged, and released. The objective of this study was to collect physiological data that could help explain any observed differences in survival estimates between groups of PIT-tagged fish released at the different sites. 


\section{METHODS}

1993

\section{Reservoir Sampling}

Seven groups of PIT-tagged hatchery chinook salmon were released between April 13 and April 21. Fish were purse-seined from Lower Granite Reservoir approximately 32 kilometers upstream from Lower Granite Dam at Nisqually John's Landing (rkm 726). Hatchery chinook salmon were sorted from other species, and up to 1500 were PIT-tagged by NMFS for each release. While the fish were being PIT-tagged (Day 1 of each release), a subsample of 100 PITtagged fish were non-lethally sampled for gill sodium, potassium-activated adenosine triphosphatase $\left(\mathrm{Na}^{+}, \mathrm{K}^{+}\right.$-ATPase) activity using the microassay method described by Schrock et al. (1994). All fish PIT-tagged by NMFS, including those we sampled, were placed into two net pens set in the river. The following evening (Day 2), just prior to release, 30 fish were removed from each of the two net pens and sacrificed with a lethal dose $(105 \mathrm{ppm})$ of tricaine methanesulfonate (MS-222). Fifteen fish from each subsample were sampled for plasma cortisol, and kidney and spleen tissue was collected for BKD analysis. The other 15 fish from each subsample were used only for BKD analysis. All sacrificed fish were measured for fork length (mm) and weight (g), and were scanned for PIT-tags. Tag numbers were reported to NMFS. Lengths and weights were used to calculate condition factor ( $K$ or Kfactor) with the equation:

$$
\text { Kfactor } \left.=10^{5} \cdot\left(\text { weight } \cdot(\text { length })^{3}\right)^{-1}\right)
$$

The 30 fish sacrificed for BKD analysis only (15 from each of the two net pens) from releases 1, 3, and 7, were individually bagged, frozen, and sent to the U. S. Fish and Wildlife Service, Lower Columbia River Fish Health Center (LCRFHC), Underwood, Washington, for disease screening. The LCRFHC screened fish for the presence of Yersinia ruckeri (the bacterial agent of enteric redmouth disease), Aeromonas salmonicida (the bacterial agent of furunculosis), infectious hematopoietic necrosis (IHN) virus, and infectious pancreatic necrosis (IPN) virus. After LCRFHC processing, the fish were sent back to the Columbia River Research Laboratory for BKD analysis using an enzyme-linked immunosorbant assay (ELISA) method described by Pascho et al. (1991).

\section{Dam Sampling}

Passive integrated transponder (PIT)-tagging was done at Lower Granite Dam and Little Goose Dam by NMFS to test survival rates from the reservoir releases to and through the different dam bypass and collection facilities. Hatchery chinook salmon were removed from the juvenile collection systems at each dam, PIT-tagged (Day 1), held in holding tanks supplied with flow-through river water, and released at various locations within the dam system the following day (Day 2). Releases of PIT-tagged fish were made into the dam spillway, juvenile collection bypass, and turbines at each of the two dams. A control release was made just below the dam at the confluence of water from the spillways, turbines, and bypass. Three sets of releases occurred at each dam to correspond to the approximate timing of the $10 \%, 50 \%$, and $90 \%$ passage at the dam of all the fish released at Lower Granite Reservoir. 
On Day 1 of each set of releases, we subsampled 30 PIT-tagged fish from the control release group for gill ATPase and sacrificed 45 untagged fish for BKD samples. When the fish were released on Day 2, we sacrificed 15 PIT-tagged fish from the control group for plasma cortisol and sent the carcasses to the LCRFHC for disease screening as previously described. We recorded fork lengths, weights, and PIT-tag numbers of all fish sampled. At Lower Granite Dam, releases were made on April 28, April 30, and May 12. The first and third releases at Little Goose Dam were made over two days because insufficient numbers of hatchery chinook salmon were collected. We sampled fish from all five days of collection: May 6 and 7 (release 1), May 8 (release 2), and May 13 and 14 (release 3). Fish from the turbine or bypass control groups were sampled immediately before they were released from the transport containers at the confluence of water from the spillways, powerhouse, and bypass.

\section{Statistical Analysis}

Statistical analyses were conducted using SAS (SAS Institute 1989). Gill $\mathrm{Na}^{+}, \mathrm{K}^{+}$-ATPase activity and condition factor within and between release sites were compared with an F-test. A chi-squared test was used to detect significant differences between the numbers of fish with and without BKD. A significance level of $\alpha=0.05$ was used in statistical tests.

\section{4}

Our collection of physiological samples for the 1994 NMFS survival study was much reduced from the 1993 sampling. Only non-lethal gill ATPase samples were collected, between April 20 and May 23, at Lower Granite Reservoir, Lower Granite Dam, Little Goose Dam, and Lower Monumental Dam.

\section{Reservoir Sampling}

One to three samples were taken at each site from both hatchery spring chinook salmon and hatchery steelhead. Both species of fish were collected from Lower Granite Reservoir at Silcott Island, where the fish were purse-seined, PIT-tagged, held for up to 50 hours to recover from handling, and released by NMFS.

\section{Dam Sampling}

The fish sampled from collection facilities at Lower Granite, Little Goose, and Lower Monumental dams were PIT-tagged, and released the following day. Gill samples were removed from the PIT-tagged fish during the tagging process or during the holding time using the same ATPase sampling protocol as in 1993.

\section{Statistical Analysis}

Statistical analysis of the gill ATPase values was performed using an F-test (SAS Institute 1989). 


\section{RESULTS}

Gill $\mathrm{Na}^{+}, \mathrm{K}^{+}$-ATPase Activity

1993

Mean values for gill $\mathrm{Na}^{+}, \mathrm{K}^{+}$-ATPase, reported in units of micromoles inorganic phosphate per milligram protein per hour $\left(\mu \mathrm{mol} \mathrm{P}_{\mathrm{i}} \cdot \mathrm{mg} \operatorname{protein}^{-1} \cdot \mathrm{h}^{-1}\right)$, were similar between releases at a given sample site, but differed significantly between sites. The mean ATPase activity for release group 3 at Lower Granite Reservoir was significantly higher $(\bar{x}=10.81$ ATPase units) than means for the other six release groups, which ranged from 9.47 to 10.40 (Table 1). However, the reproducibility of the microassay for ATPase is $4 \mu \mathrm{mol} \mathrm{P}_{\mathrm{i}} \cdot \mathrm{mg} \mathrm{protein}^{-1} \cdot \mathrm{h}^{-1}$, therefore differences less than 4 units are not considered biologically significant. No other significant differences in mean ATPase values were found between releases from either Lower Granite Dam or Little Goose Dam. Comparison between the three sample sites revealed significant differences in mean ATPase values that were biologically significant. Mean gill ATPase activity in fish from Lower Granite Reservoir was significantly lower $(\bar{x}=10.08)$ than in fish from Lower Granite Dam $(\bar{x}=$ 16.79), and gill ATPase activity in fish from Little Goose Dam was significantly higher ( $\bar{x}=$ 21.35) than in fish from the other two sites (Table 1).

\section{Condition Factor}

Patterns in condition factor were similar to patterns in gill ATPase. At Lower Granite Reservoir, the seven releases fell into three significantly different groups, with condition factors ranging from 1.0342 to 1.0804 (Table 1). The other two sample sites showed no significant differences in condition factor between releases. Again, when comparisons were made between mean values from the three sites, significantly different values were found. The highest mean condition factor, 1.0595, was found at Lower Granite Reservoir, while fish at Little Goose Dam had a mean value of 0.9719, and fish collected at Lower Granite Dam had the lowest mean condition factor $(\bar{x}=0.9582$; see Table 1$)$.

\section{Plasma Cortisol}

Mean values were calculated for plasma cortisol $\left(\mathrm{ng} \cdot \mathrm{mL}^{-1}\right)$ from each release in the reservoir and dams. The only site with significantly different values between releases was Lower Granite Reservoir (Table 1). Fish from release 7 in the reservoir had significantly higher plasma $\operatorname{cortisol}(\bar{x}=95.05)$ than did the prior six releases (ranging from 55.45 to 83.97). Neither Lower Granite Dam (with a range of 184.14 to 273.45) nor Little Goose Dam (ranging from 198.98 to 259.30) had significantly different plasma cortisol levels between release groups. Between-site comparisons of mean plasma cortisol did show significant differences (Table 1). Mean cortisol concentration from fish collected at Lower Granite Reservoir $(\bar{x}=68.88)$ was significantly lower than mean cortisol from fish collected at Lower Granite Dam $(\bar{x}=232.29)$ and Little Goose Dam $(\bar{x}=231.98)$.

\section{Bacterial Kidney Disease}

The percentage of fish with BKD did not differ significantly between any of the release groups within a sample site. Between 33\% and 68\% of fish in each group were diagnosed with BKD (Table 2). No significant differences in BKD prevalence between sample sites were found. 


\section{Disease Screening}

All 195 fish sent to the LCRFHC for disease analysis tested negative for Y. ruckeri, A. salmonicida, IHN, and IPN.

\section{4}

\section{Gill $\mathrm{Na}^{+}, \mathrm{K}^{+}$-ATPase Activity}

Table 3 gives the mean gill ATPase, standard errors, and statistically significant differences for fish collected at each site and sampling date in 1994. Gill ATPase increased over time at a given site in both hatchery spring chinook salmon and hatchery steelhead, and tended to increase as the fish traveled downstream.

\section{DISCUSSION}

Spring chinook salmon monitored as part of the National Marine Fisheries Service Lower Granite Survival Study were sampled in 1993, and both yearling hatchery steelhead and spring chinook salmon were sampled in 1994. Physiological measurements were made to test for differences among individuals from multiple releases from single sites, and between releases from different sites. Fish collected in Lower Granite Reservoir or at Snake River dams below the reservoir displayed different levels of smoltification.

Mean gill $\mathrm{Na}^{+}, \mathrm{K}^{+}$-ATPase, condition factor, and plasma cortisol values differed significantly between multiple releases at several of the release sites. However, based on previous work at hatcheries and dams in the Columbia Basin, we believe the relatively small differences between release groups within a site were not biologically significant, but the differences between upriver and downriver sampling locations were biologically significant (Beeman et. al. 1991; Maule et al. 1994). Smolt development progressed as the fish traveled further downstream, as evidenced by the increase in gill ATPase from one site to the next, and the general trend of decreasing condition factor from Lower Granite Reservoir to Little Goose Dam. The increases in gill ATPase over time and from upstream to downstream sites in 1993 and 1994 conformed to the results of previous studies (Maule et al. 1994; Zaugg and McLain 1972).

The fish in this study were not severely incapacitated by disease, as evidenced by low mortality. Bacterial kidney disease was fairly prevalent, but not acute (Maule et al. 1996a). Muir et al. (1995) reported no difference between survival of any of the groups released from a particular site. Disease screening by the LCRFHC revealed no Y. ruckeri, A. salmonicida, IHN or IPN in fish from each release.

Analysis of blood plasma cortisol showed that fish sampled at dams were more stressed than fish collected in the reservoir. No dam imposed greater stress than any other, but the overall experience of being collected, held in tanks, and released at the dams was more stressful than being purse-seined, held in net pens, and released into the reservoir.

This study was originally designed to detect physiological and morphological differences between groups of fish from multiple releases at a particular sample site. These data would then be used to help explain possible differences in travel time and survival. The data collected suggest 
no biological differences when comparing releases from a single site, which supports the findings of Iwamoto et al. (1994) and Muir et al. (1995), who found no differences in travel time or survival between multiple releases of fish from an individual site. The most significant finding was the increased stress, as measured by cortisol levels, associated with release at a dam. 
CHAPTER TWO TABLES 
Table 1. Mean $( \pm \mathrm{SE})$ gill $\mathrm{Na}^{+}, \mathrm{K}^{+}$-ATPase, condition factor (Kfactor), and plasma cortisol of hatchery spring chinook salmon sampled during the Lower Granite Survival Study in 1993. Data are arranged by releases within a site and by site. Mean values with letters in common differ significantly from others within that group based on an F-test of differences between releases within a site, or between sites $(P \leq 0.05)(\mathrm{LRS}=$ Lower Granite Reservoir; LGR $=$ Lower Granite Dam; LGS = Little Goose Dam).

\begin{tabular}{lllllllllll}
\hline Site & Release & Date & & \multicolumn{2}{c}{ ATPase } & & \multicolumn{2}{c}{ Kfactor } & & \multicolumn{3}{c}{ Cortisol } \\
& & $\mathrm{N}$ & $\bar{x}$ & $\mathrm{SE}$ & $\mathrm{N}$ & $\bar{x}$ & $\mathrm{SE}$ & $\mathrm{N}$ & $\bar{x}$ & $\mathrm{SE}$ \\
\hline
\end{tabular}

Data by Releases Within a Release Site

$\begin{array}{llrrrrrlllll}\text { LRS } & \text { R1 } & 4 / 13-14 / 93 & 100 & 9.47 \mathrm{~b} & 0.23 & 158 & 1.0785 \mathrm{a} & 0.0068 & 29 & 61.93 \mathrm{a} & 5.43 \\ \text { LRS } & \text { R2 } & 4 / 15 / 93 & 99 & 10.14 \mathrm{ab} & 0.20 & 159 & 1.0804 \mathrm{a} & 0.0054 & 26 & 62.54 \mathrm{a} & 6.29 \\ \text { LRS } & \text { R3 } & 4 / 16 / 93 & 100 & 10.81 \mathrm{a} & 0.22 & 158 & 1.0624 \mathrm{ab} & 0.0044 & 30 & 58.67 \mathrm{a} & 5.79 \\ \text { LRS } & \mathrm{R} 4 & 4 / 17 / 93 & 99 & 10.17 \mathrm{ab} & 0.23 & 156 & 1.0342 \mathrm{c} & 0.0054 & 27 & 62.39 \mathrm{a} & 8.85 \\ \text { LRS } & \text { R5 } & 4 / 18 / 93 & 99 & 10.40 \mathrm{ab} & 0.26 & 159 & 1.0660 \mathrm{ab} & 0.0050 & 29 & 55.46 \mathrm{a} & 4.42 \\ \text { LRS } & \mathrm{R} 6 & 4 / 19 / 93 & 92 & 9.51 \mathrm{~b} & 0.32 & 152 & 1.0480 \mathrm{bc} & 0.0064 & 30 & 83.97 \mathrm{ab} & 9.57 \\ \text { LRS } & \text { R7 } & 4 / 20 / 93 & 98 & 9.98 \mathrm{ab} & 0.34 & 162 & 1.0466 \mathrm{bc} & 0.0050 & 30 & 95.05 \mathrm{~b} & 8.55 \\ & & & & & & & & & & & \\ \text { LGR } & \mathrm{R} 1 & 4 / 27 / 93 & 30 & 15.85 \mathrm{a} & 0.79 & 89 & 0.9664 \mathrm{a} & 0.0088 & 15 & 184.14 \mathrm{a} & 20.96 \\ \text { LGR } & \text { R2 } & 4 / 29 / 93 & 30 & 17.13 \mathrm{a} & 0.84 & 89 & 0.9460 \mathrm{a} & 0.0069 & 15 & 239.27 \mathrm{a} & 60.50 \\ \text { LGR } & \text { R3 } & 5 / 11 / 93 & 30 & 17.38 \mathrm{a} & 1.06 & 90 & 0.9618 \mathrm{a} & 0.0059 & 15 & 273.45 \mathrm{a} & 43.07 \\ & & & & & & & & & & & \\ \text { LGS } & \text { R1 } & 5 / 5-6 / 93 & 60 & 21.23 \mathrm{a} & 0.72 & 180 & 0.9624 \mathrm{a} & 0.0066 & 31 & 259.30 \mathrm{a} & 19.92 \\ \text { LGS } & \text { R2 } & 5 / 7 / 93 & 30 & 20.13 \mathrm{a} & 0.88 & 89 & 0.9841 \mathrm{a} & 0.0092 & 15 & 237.12 \mathrm{a} & 32.44 \\ \text { LGS } & \text { R3 } & 5 / 12 / 93 & 60 & 22.09 \mathrm{a} & 0.61 & 170 & 0.9757 \mathrm{a} & 0.0067 & 28 & 198.98 \mathrm{a} & 16.46\end{array}$

Data by Site

$\begin{array}{lrrrrrrrrrr}\text { LRS } & 4 / 13-20 / 93 & 687 & 10.08 \mathrm{a} & 0.10 & 1104 & 1.0595 \mathrm{a} & 0.0021 & 201 & 68.88 \mathrm{a} & 2.88 \\ \text { LGR } & 4 / 27-5 / 11 / 93 & 90 & 16.79 \mathrm{~b} & 0.52 & 268 & 0.9582 \mathrm{~b} & 0.0042 & 45 & 232.29 \mathrm{~b} & 25.74 \\ \text { LGS } & 5 / 5-12 / 93 & 150 & 21.35 \mathrm{c} & 0.42 & 439 & 0.9719 \mathrm{c} & 0.0042 & 74 & 231.98 \mathrm{~b} & 12.54\end{array}$


Table 2. Presence of bacterial kidney disease as percent positive (\%Pos) and sample sizes of hatchery spring chinook salmon sampled during the Lower Granite Survival Study in 1993. A chi-squared test was used to determine significant differences $(P \leq 0.05)$ between releases from a release site, or between release sites (LRS = Lower Granite Reservoir; LGR = Lower Granite Dam; LGS = Little Goose Dam).

\begin{tabular}{|c|c|c|c|c|}
\hline Site & Release & Date & $\mathrm{N}$ & $\%$ Pos \\
\hline \multicolumn{5}{|c|}{ Data by Releases Within a Release Site } \\
\hline LRS & R1 & 4/13-14/93 & 53 & 50.94 \\
\hline LRS & R2 & 4/15/93 & 58 & 53.45 \\
\hline LRS & R3 & $4 / 16 / 93$ & 53 & 58.49 \\
\hline LRS & R4 & $4 / 17 / 93$ & 58 & 60.34 \\
\hline LRS & R5 & $4 / 18 / 93$ & 33 & 33.33 \\
\hline LRS & R6 & $4 / 19 / 93$ & 29 & 48.28 \\
\hline LRS & R7 & $4 / 20 / 93$ & 58 & 48.28 \\
\hline LGR & R1 & $4 / 27 / 93$ & 49 & 48.98 \\
\hline LGR & R2 & $4 / 29 / 93$ & 45 & 48.89 \\
\hline LGR & R3 & $5 / 11 / 93$ & 45 & 66.67 \\
\hline LGS & R1 & $5 / 5-6 / 93$ & 94 & 40.43 \\
\hline LGS & $\mathrm{R} 2$ & $5 / 7 / 93$ & 47 & 55.32 \\
\hline LGS & R3 & $5 / 12 / 93$ & 88 & 53.41 \\
\hline \multicolumn{5}{|c|}{ Data by Site } \\
\hline LRS & & $4 / 13-20 / 93$ & 342 & 51.75 \\
\hline LGR & & $4 / 27-5 / 11 / 93$ & 139 & 54.68 \\
\hline LGS & & $5 / 5-12 / 93$ & 229 & 48.47 \\
\hline
\end{tabular}


Table 3. Mean ( \pm SE) gill $\mathrm{Na}^{+}, \mathrm{K}^{+}$-ATPase in hatchery spring chinook salmon (HSPC) and hatchery steelhead (HSTH) sampled during the Lower Granite Survival Study in 1994. Mean values with letters in common differ significantly from others within that group based on an F-test of differences between releases within a site, or between sites $(P \leq 0.05)$ (LRS $=$ Lower Granite Reservoir; LGR = Lower Granite Dam; LGS = Little Goose Dam; LMN = Lower Monumental Dam).

\begin{tabular}{|c|c|c|c|c|c|}
\hline Species & Site & Date & $\mathrm{N}$ & $\bar{x}$ & SE \\
\hline \multicolumn{6}{|c|}{ Within Sites, by Date } \\
\hline \multirow[t]{10}{*}{ HSPC } & LRS & $4 / 28 / 94$ & 29 & $14.15 \mathrm{a}$ & 0.64 \\
\hline & LRS & $5 / 10 / 94$ & 30 & $15.50 \mathrm{a}$ & 0.98 \\
\hline & LGR & $4 / 20 / 94$ & 28 & $16.52 b$ & 0.77 \\
\hline & LGR & $4 / 27 / 94$ & 30 & $17.30 \mathrm{~b}$ & 0.81 \\
\hline & LGR & $5 / 11 / 94$ & 27 & $22.42 \mathrm{a}$ & 1.12 \\
\hline & LGS & $4 / 27 / 94$ & 30 & $18.51 \mathrm{~b}$ & 0.75 \\
\hline & LGS & $5 / 05 / 94$ & 30 & $22.06 a$ & 0.72 \\
\hline & LMN & $5 / 05 / 94$ & 30 & $22.94 a$ & 0.59 \\
\hline & LMN & $5 / 12 / 94$ & 30 & $22.88 \mathrm{a}$ & 0.80 \\
\hline & LMN & $5 / 17 / 94$ & 30 & $19.62 b$ & 1.17 \\
\hline \multirow[t]{7}{*}{ HSTH } & LRS & $4 / 28 / 94$ & 30 & $10.79 b$ & 0.52 \\
\hline & LRS & $5 / 10 / 94$ & 30 & $12.50 \mathrm{ba}$ & 0.77 \\
\hline & LRS & $5 / 19 / 94$ & 30 & $14.09 \mathrm{a}$ & 0.78 \\
\hline & LGR & $5 / 19 / 94$ & 29 & 13.28 & 0.96 \\
\hline & LGS & $5 / 13 / 94$ & 30 & $16.38 \mathrm{a}$ & 0.78 \\
\hline & LGS & $5 / 17 / 94$ & 30 & $15.80 \mathrm{a}$ & 1.00 \\
\hline & LMN & $5 / 23 / 94$ & 30 & 14.42 & 0.71 \\
\hline \multicolumn{6}{|c|}{ Between Sites } \\
\hline \multirow[t]{4}{*}{ HSPC } & LRS & $4 / 28-5 / 10$ & 59 & $14.83 \mathrm{c}$ & 0.59 \\
\hline & LGR & $4 / 20-5 / 11$ & 85 & $18.67 b$ & 0.59 \\
\hline & LGS & $4 / 27-5 / 05$ & 60 & $20.28 \mathrm{ba}$ & 0.56 \\
\hline & $\mathrm{LMN}$ & $5 / 05-5 / 17$ & 90 & $21.81 \mathrm{a}$ & 0.53 \\
\hline \multirow[t]{4}{*}{ HSTH } & LRS & $4 / 28-5 / 19$ & 90 & $12.46 \mathrm{~b}$ & 0.43 \\
\hline & LGR & $5 / 19$ & 29 & $13.28 b$ & 0.96 \\
\hline & LGS & $5 / 13-5 / 17$ & 60 & $16.09 a$ & 0.63 \\
\hline & LMN & $5 / 23$ & 30 & $14.42 \mathrm{ba}$ & 0.71 \\
\hline
\end{tabular}




\title{
CHAPTER THREE
}

\section{Mucus Lysozyme as a Non-Lethal Measure of Health in Pacific Salmon}

\author{
Robin M. Schrock \\ Stanley G. Smith \\ Jack D. Hotchkiss \\ Alec G. Maule
}

\begin{abstract}
Mucus lysozyme reference levels were established for juvenile coho salmon (Oncorhynchus kisutch), and juvenile and adult chinook salmon (O. tshawytscha) to identify patterns of change in lysozyme concentrations during smoltification and disease episodes. The objectives of the study were to establish a reproducible method of sampling and analysis for mucus lysozyme, to determine baseline lysozyme concentrations in hatchery reference stocks, and to determine if mucus lysozyme levels could be used as an index of smolt condition and health. One $\mu \mathrm{L}$ of mucus provided a meaningful measurement of lysozyme for comparison among groups of juvenile and adult salmon. A notable decrease in mucus lysozyme levels occurred during smoltification. Significant differences in mucus lysozyme levels were found between healthy and infected fish in disease challenge experiments. Mucus lysozyme levels in juvenile coho salmon were in the same range as levels in spring chinook salmon, when health and condition were similar. Stress may affect indicators of non-specific immune response such as lysozyme by initiating an acute disease episode in fish suffering a chronic infection.
\end{abstract}

\section{INTRODUCTION}

The successful adaptation of juvenile salmon for life in the marine environment involves complex changes in their morphology, physiology, and behavior (Hoar 1976; Wedemeyer et al. 1980; Folmar and Dickhoff 1981) within constraints of the environment (Wedemeyer et al. 1980; Zaugg 1982b; McCormick et al. 1987; Pagliarani et al. 1991). During the parr-to-smolt transformation, marked changes occur in length and weight (Zaugg and Beckman 1990), condition factor, and growth rate (Wedemeyer et al. 1980). Associated physiological changes include increases in enzymes such as gill sodium, potassium-activated adenosine triphosphatase ( $\mathrm{Na}^{+}, \mathrm{K}^{+}$-ATPase) (Saunders and Henderson 1978; Zaugg and McLain 1972; Rondorf et al. 1988, 1989; McCormick et al. 1989; Beeman et al. 1990, 1991; Maule et al. 1994) and changes in the amount of guanine deposited in the skin (Staley and Ewing 1992). Several stocks of Columbia River salmonids are threatened with extinction, and the Assessment of Smolt Condition for Travel Time Analysis project of the Columbia River Research Laboratory has worked to develop nonlethal methods of evaluating fish health and condition, including a microassay for gill $\mathrm{Na}^{+}, \mathrm{K}^{+}-$ ATPase activity (Schrock et al. 1994), a method of determining smoltification using body 
morphometric indices (Beeman et al. 1994, 1995), and quantification of smolt silvering using skin reflectance (Haner et al. 1995).

No single factor evaluating smolt condition or health has been shown to adequately predict juvenile migration success or numbers of returning adults, although gill $\mathrm{Na}^{+}, \mathrm{K}^{+}$-ATPase levels have long been used as an indicator of smoltification and predictor of migration success (Zaugg and McLain 1970; McCartney 1976; Giles and Vanstone 1976). Interactions of hormonal and immunological factors, along with environmental factors such as river flow (Beeman et al. 1991), contribute to the complex suite of changes necessary to ensure adaptation to the marine environment. We investigated lysozyme, a non-specific immune enzyme found in mucus, as a potential indicator of smolt condition and health in salmon.

Lysozyme has been detected in tissues such as gill cartilage, spleen, kidney, epithelium, and skin (Murray and Fletcher 1976). Tissues rich in leucocytes, monocytes, macrophages and polymorphonucleated granulocytes are thought to be the sites of lysozyme production (Lie et al. 1989). Lysozyme has also been localized in the eosinophilic granule cells of the intestines of Atlantic salmon Salmo salar (Sveinbjørnsson et al. 1996). The distribution of lysozyme in skin and intestinal mucus allows for a non-invasive means of assessing fish health and condition.

Plasma lysozyme has been shown to decrease in salmonids during the parr-to-smolt transformation, corresponding to a decrease in blood leucocytes and lymphocyte numbers (Muona and Soivio 1992). These changes are associated with reduced disease resistance (Maule et al. 1987). Numerous other blood constituents change in concentration during smoltification and cooperate to allow for successful entry into seawater (Folmar and Dickhoff 1981; Maule et al. 1987; Bradley and Rourke 1988; Borgatti et al. 1992; Franklin et al. 1992). Endocrine control of smoltification involves pituitary, thyroid, and inter-renal hormones that steer many of the adaptive changes necessary for smoltification (see Barron 1986 for a review). Cortisol, a corticosteroid produced in the inter-renal tissue in teleosts, is involved in osmoregulation and has been found to exhibit seasonal changes in concentration associated with smoltification (Specker and Schreck 1982; Redding et al. 1984; Barton et al. 1985; Maule et al. 1987). Increases in cortisol may indicate impairment of general immune competence, as evidenced by an accompanying decrease in splenic lymphocytes and circulating leucocytes (Maule et al. 1987, 1993).

Lysozyme has been proposed as a more phenotypically stable stress indicator than cortisol, based on significant differences in lysozyme levels in salmonids selectively bred to produce stocks with high- and low-cortisol stress response (Fevolden et al. 1991). Lysozyme has been found to have a higher heritability index than cortisol (Fevolden et al. 1994) and may, therefore, be a useful reference measurement for assessing the health status of fish during smoltification if heritable baseline levels of mucus lysozyme are found. Extensive selection programs for cortisol response to stress have revealed significant differences in stock lysozyme levels and varied resistance to specific pathogens (Fevolden et al. 1991, 1992).

Lysozyme is known to cause lysis of Gram-positive bacteria (Chipman and Sharon 1969). The antibacterial effects of lysozyme against Gram-negative bacteria common in farmed fish have been investigated in Norway (Grinde 1989). Blood lysozyme levels in both rainbow trout Oncorhynchus mykiss (Dautigny et al. 1991) and Atlantic salmon (Grinde 1989) are known to vary by pathogen, level of infection, and time course of the disease (Chu and LaPeyre 1989). Lysozyme in salmonid eggs was found to be antibacterial (Yousif et al. 1994). 
Significant genetic variation in blood lysozyme in rainbow trout has been documented (Røed et al. 1993), and recent studies have found a negative genetic correlation between lysozyme activity and the resistance of Atlantic salmon to bacterial kidney disease (BKD) (Fevolden et al. 1994). We have monitored infection levels of Renibacterium salmoninarum, the causative agent of BKD, in hatchery juvenile chinook salmon (O. tshawytscha) in the Pacific Northwest. Levels of infection differ among hatcheries, and increase in migrating fish over time and as they travel downstream (Beeman et al. 1991; Maule et al. 1996b). Because enzyme-linked immunosorbent assay (ELISA) methods for BKD require lethal sampling of kidneys to determine severity of infection, development of mucus lysozyme concentration as an indicator of fish health would be important for non-lethal monitoring of declining salmonid stocks.

The characterization of two distinct rainbow trout lysozymes with different specific activities (Grinde et al. 1988a; Dautigny et al. 1991) suggests that multiple lysozymes may be present in Pacific salmon. The higher activity of Type I lysozyme than Type II in rainbow trout (Grinde 1988a) raises questions about the possible function of the two types, and about how the predominance of each type might change as juvenile salmon develop osmoregulatory competence. Identification of lysozymes with different $\mathrm{pH}$ optima in freshwater and marine fish (Sankaran and Gurnani 1972) raised speculation about potential changes in the localization and concentration of distinct lysozymes at different stages in the development of anadromous fish. We investigated changes in mucus lysozyme associated with smoltification.

The focus of our research was to develop a quantitative method of sampling mucus lysozyme, and to determine mucus lysozyme concentrations in juvenile and adult salmon under varying conditions. We evaluated the applicability of mucus lysozyme concentration as an indicator of salmon health. Preliminary investigations, in conjunction with other established research projects, allowed for broad-based monitoring of conditions that might affect mucus lysozyme concentrations. We sampled fish from ongoing experiments to determine the following: 1) baseline levels of skin, nare, and vent mucus lysozyme in juvenile salmon held in hatcheries; 2) differences among species or hatchery stocks held under similar conditions; 3) the effect of specific hatchery practices on lysozyme levels; 4) changes in mucus lysozyme levels occurring seasonally or over the period associated with smoltification; 5) differences in mucus lysozyme levels between healthy and diseased fish; 6) baseline lysozyme levels in returning adult salmon; and 7) comparisons among the three kinds of mucus (skin, nare, vent) to find the best indicator of changes in lysozyme levels. Holding conditions in each experiment were considered for possible effects on lysozyme levels.

\section{METHODS}

\section{Fish Collection Procedures}

Baseline Levels in Hatchery Reference Stocks

Spring and summer chinook salmon released from hatcheries in 1994 were assayed for nare mucus lysozyme levels to determine baseline lysozyme levels at release, and to determine if stock differences might exist. Snake River basin hatcheries included Sawtooth Hatchery (Idaho Department of Fish and Game, IDFG), Rapid River Hatchery (IDFG), McCall Hatchery (IDFG), and Dworshak National Fish Hatchery (NFH) (USFWS) in Idaho, and Lookingglass Hatchery 
(Oregon Department of Fish and Wildlife, ODFW) in Oregon. Columbia River hatcheries included Entiat NFH, Winthrop NFH, Ringold Hatchery (Washington Department of Fish and Wildlife, WDFW) and Wells Hatchery (WDFW) in Washington. Juvenile fish were sampled approximately one week before release as part of the annual Smolt Monitoring Program.

Lysozyme samples from adult salmon were obtained from returning adults at two hatcheries, Carson NFH and Little White Salmon NFH in Washington. Spring chinook salmon at Carson NFH were sampled twice during holding in 1993: once on June 17, near the end of the run to the hatchery, and later on August 10, when the fish were spawned. Fish were anaesthetized with $0.1 \mathrm{~g} \cdot \mathrm{L}^{-1}$ tricaine methanesulfonate (MS-222), and euthanized by a sharp blow to the head. Females were bled by severing the caudal peduncle, and all fish were spawned, followed by kidney biopsy for health screening by the U.S. Fish and Wildlife Service Lower Columbia River Fish Health Center, Underwood, Washington. We received fish for sampling 15 to 30 minutes after they were anaesthetized. Skin mucus, plasma and secondary circulation fluid were collected. In 1994, we sampled for serum and secondary circulation fluid, and skin and vent mucus. Sampling conditions at Carson in 1994 were the same as in 1993. In 1994 only, Little White Salmon NFH adult spring chinook salmon were tested for serum, secondary circulation fluid, and skin mucus lysozyme once per week during two consecutive weeks. Sampling conditions at Little White Salmon NFH were similar to those at Carson NFH. The length of time between fish capture and lysozyme sampling varied greatly among individual fish at both hatcheries.

\section{Experimental Fish from Covered and Uncovered Hatchery Raceways}

Juvenile coho salmon (O. kisutch) were sampled at Willard National Fish Hatchery (WNFH) and juvenile spring chinook salmon (O. tshawytscha) were sampled at Little White Salmon NFH (LWSNFH), in 1993 and 1994. Fish were part of a covered raceway experiment, and both the control (uncovered) and covered groups were sampled to determine how this practice might affect lysozyme levels. Fish were kept in flow-through raceways at WNFH $(24.4 \times$ $2.4 \times 0.7 \mathrm{~m})$ and at LWSNFH $(22.4 \times 2.4 \times 1.0 \mathrm{~m})$. River water from the Little White Salmon River supplied both hatcheries, and water temperature varied from 3 to $9{ }^{\circ} \mathrm{C}$ during the sampling period. For covered treatment groups, camouflage netting was mounted $45 \mathrm{~cm}$ above the water surface in late July or early August and was left in place until the release date in April. Mucus lysozyme levels from skin, nare, and vent were determined monthly from December through April, which included the period associated with smoltification in these stocks. Coho salmon weighed about $2 \mathrm{~g}$ (220 fish $\cdot \mathrm{lb}^{-1}$ ) when stocked (approximately 65,000 fish per raceway), and weighed about $28 \mathrm{~g}\left(16 \mathrm{fish} \cdot \mathrm{lb}^{-1}\right)$ at release. Spring chinook salmon weighed about $4 \mathrm{~g}$ (113 fish $\cdot \mathrm{lb}^{-1}$ ) when stocked (approximately 47,000 fish per raceway), and were about $28 \mathrm{~g}\left(16 \mathrm{fish} \cdot \mathrm{lb}^{-1}\right)$ at release.

\section{Disease Challenge Experiments}

Spring chinook salmon from Entiat NFH, held at the Columbia River Research Laboratory, Cook, Washington, were sampled in 1993 to compare lysozyme levels in a control group of fish of low-BKD parentage to levels in fish of the same parentage exposed to $R$. salmoninarum. Plasma and mucus lysozyme levels were compared to determine ranges and seasonal changes. Fish were sampled 3 and 6 weeks after an initial challenge with $R$. salmoninarum on May 20, 1993, then at 6, 9, 12, 15, and 17 weeks after a second exposure on 
August 24, 1993. Experimental fish were held at 500 fish per $1.5-\mathrm{m}$ circular tank $\left(6 \mathrm{~g} \cdot \mathrm{L}^{-1}\right)$ under natural photoperiod. Temperature in experimental tanks was between 12 and $13{ }^{\circ} \mathrm{C}$. Fish were disease-challenged by crowding them for $24 \mathrm{~h}$ into $78 \mathrm{~L}$ aerated water containing $9.8 \cdot 10^{6}$ bacteria $\cdot \mathrm{mL}^{-1}$. Control fish were challenged with the same sterile peptone-saline solution used to suspend the bacteria for the disease challenge. Fish were monitored over a prolonged period to determine if the time course and severity of the infection would be detected as differences in lysozyme levels between control and disease-challenged fish, distinct from seasonal changes that might occur during the experiment. After the fish were sampled at week 12, they were stresschallenged as follows: the experimental tanks were drained completely, and the fish were allowed to struggle on the bottom of the tanks for $1 \mathrm{~min}$, then the tanks were filled as quickly as possible. The exercise was repeated two additional times, with three-hour recovery periods intervening between stress challenges.

The disease challenge experiment was repeated in 1994. Skin, nare, and vent mucus lysozyme samples were collected before the challenge, and at 2, 4, 6, 8, and 10 weeks postchallenge. Fish were reared at $12{ }^{\circ} \mathrm{C}$ in $1.5-\mathrm{m}$ circular tanks at $12 \mathrm{~g} \cdot \mathrm{L}^{-1}$ (about 500 fish per $1.5 \mathrm{~m}$ circular tank) under natural photoperiod. The fish were challenged with $1.27 \cdot 10^{7}$ bacteria $\cdot \mathrm{mL}^{-1}$ in $75 \mathrm{~L}$ aerated water for 24 hours. Control fish were peptone-saline challenged as in 1993.

\section{Lysozyme Sample Collection}

Preliminary studies of mucus lysozyme in smolts were used to determine reproducible and quantitative sampling and analysis techniques. We optimized the composition, molarity, and $\mathrm{pH}$ of buffers for sampling and analysis by modifying buffers previously used by Davies et al. (1969), Ellis (1990), Muona and Soivio (1992), and Sankaran and Gurnani (1972). All mucus samples were collected with a $1-\mu \mathrm{L}$ inoculation loop, and were immediately extracted into $50 \mu \mathrm{L}$ of 0.04 M Sorenson's phosphate buffer at $\mathrm{pH}$ 6.2, by vigorous mixing. Samples were stored at $-80{ }^{\circ} \mathrm{C}$ until analyzed.

To collect skin mucus, both sides of the loop were rubbed against the fish in an area between the vent and lateral line, the loop was removed in a perpendicular fashion to ensure consistent filling of the aperture, and the sample was immediately extracted. Mucus was scraped from the roof of the mouth in a similar procedure. Nare samples were collected by inserting the loop into the nare, turning the loop one-quarter, then removing it. Vent mucus was collected by inserting the loop into the vent for a distance twice the length of the loop, then withdrawing it along the intestinal wall against gently applied external pressure.

In fish that were sacrificed, plasma or serum was collected to provide reference levels for comparison with mucus lysozyme. Plasma from the caudal artery, obtained by severing the caudal fin, was initially collected in heparinized Natelson tubes. Lysozyme concentrations were extremely low, and although results from heparinized plasma do appear in the literature, heparin is known to bind lysozyme (Schultz 1987). We therefore discontinued use of heparinized tubes. Subsequent plasma samples were collected in ethylenediaminetetraacetic acid (EDTA)-coated Natelson tubes, or serum was collected in untreated tubes. Serum from adult chinook salmon was collected from the caudal artery using a 22-gauge needle and syringe. Plasma was immediately separated from the cells by centrifugation, while serum samples were allowed to clot over a period of several hours, then separated by centrifugation. 
Secondary circulation fluid was collected from adult salmon by making a shallow incision perpendicular to the lateral line, and inserting a Natelson tube into the lateral subcutaneous vessel that runs parallel to the lateral line. Fluid was forced into the tube by gently pressing along the lateral line toward the tube.

\section{Lysozyme Analysis}

Lysozyme concentrations were determined by a microplate adaptation of Sankaran and Gurnani's (1972), and Muona and Soivio's (1992) adaptations of Litwack's turbidimetric method (1955). The decrease in absorbance of a $0.025 \%$ weight per unit volume Micrococcus lysodeikticus solution in $0.02 \mathrm{M}$ sodium acetate buffer ( $\mathrm{pH}$ 5.5) was measured at $450 \mathrm{~nm}$ after a 20-min incubation at $37^{\circ} \mathrm{C}$. Results were calculated from the decrease in absorbance as measured against a hen egg white lysozyme (HEWL) standard, and were reported as $\mu \mathrm{g} \cdot \mathrm{mL}^{-1} \mathrm{HEWL}$. Ascites fluid from one juvenile spring chinook salmon was diluted, frozen in small aliquots, and used as a control for inter-assay variability.

\section{Statistical Analysis}

Data were analyzed using a one-way analysis of variance of lysozyme concentration by treatment group, among sample dates, and between species. Scheffés test was used to adjust for varied sample sizes caused by sample loss due to sample vial failure during storage in liquid nitrogen. Comparisons were made by multiple range pairwise analysis, with a significance level of $\alpha=0.05$.

\section{RESULTS}

\section{Baseline Levels in Hatchery Reference Stocks Hatchery Release Groups}

Analysis of variance of nare mucus lysozyme concentrations from hatchery release groups sampled between March 2 and April 12, 1994, showed significant differences in mean nare lysozyme $(P \leq 0.05)$ (Table 1$)$. Summer chinook from Wells Hatchery had the lowest mean nare lysozyme levels $\left(276 \mu \mathrm{g} \cdot \mathrm{mL}^{-1}\right)$, while spring chinook from Lookingglass Hatchery had the highest mean nare mucus lysozyme levels $\left(588 \mu \mathrm{g} \cdot \mathrm{mL}^{-1}\right)$. Mean levels for all the hatcheries agreed with the ranges exhibited by coho salmon and spring chinook salmon at Willard NFH and Little White Salmon NFH during the same season.

\section{Adult Salmon}

Preliminary samples from adult chinook salmon included two sample dates in 1993 at Carson NFH when fish were being held for spawning. Mean plasma lysozyme decreased significantly $(P \leq 0.05)$ from $24.8 \mu \mathrm{g} \cdot \mathrm{mL}^{-1}$ (June 17,1993$)$ to $13.6 \mu \mathrm{g} \cdot \mathrm{mL}^{-1}$ (August 10, 1993), and secondary circulation fluid decreased from 26.3 to $24.6 \mu \mathrm{g} \cdot \mathrm{mL}^{-1}$ (Table 2).

Sampling at Carson NFH was repeated in 1994, including serum and secondary circulation fluid, with the addition of skin and vent mucus lysozyme (Table 3). Serum lysozyme levels were comparable to those of plasma from the August sample in 1993, with a mean of $11.4 \pm 0.4 \mu \mathrm{g}$. $\mathrm{mL}^{-1}(N=236)$. Secondary circulation lysozyme concentrations, $16.0 \pm 0.2 \mu \mathrm{g} \cdot \mathrm{mL}^{-1}(N=231)$, 
paralleled serum lysozyme concentrations. Both serum and secondary circulation lysozyme varied significantly during the sampling period, with serum levels always lower than secondary circulation levels. Neither skin nor vent mucus lysozyme concentrations differed significantly among the three sample dates. Mean vent mucus lysozyme concentrations were over ten times greater than skin mucus lysozyme concentrations.

Adult spring chinook salmon at Little White Salmon NFH in 1994 had a mean serum lysozyme concentration of $6.2 \pm 0.6 \mu \mathrm{g} \cdot \mathrm{mL}^{-1}(N=59)$ and secondary circulation lysozyme of $17.9 \pm 0.5 \mu \mathrm{g} \cdot \mathrm{mL}^{-1}(N=74)$ (Table 4). The mean skin mucus lysozyme concentration was $67 \pm$ $7 \mu \mathrm{g} \cdot \mathrm{mL}^{-1}(N=76)$. There was a slight increase in serum lysozyme between sample dates. Skin mucus and secondary circulation lysozyme remained constant. Lysozyme levels of Little White Salmon NFH spring chinook salmon in 1994 were comparable to levels for chinook salmon at Carson NFH in 1994, with serum levels being within the lower part of the range found at Carson. Early serum and secondary circulation lysozyme levels at Carson NFH in 1993 were higher than serum and secondary circulation at Little White Salmon NFH in 1994. Skin mucus lysozyme concentration was lower at Carson NFH than at Little White Salmon NFH.

\section{Experimental Fish from Covered and Uncovered Hatchery Raceways}

Plasma lysozyme concentrations were compared between coho salmon reared in open and covered raceways at Willard NFH immediately before release (April 7, 1993). There was no significant difference in mean plasma lysozyme concentrations between control and covered groups, or between replicate groups within the individual treatments (Appendix O1); therefore, data from both groups were pooled. The mean plasma lysozyme concentration was $7.0 \pm 0.5 \mu \mathrm{g}$. $\mathrm{mL}^{-1}(N=45)$.

A continuation of the covered raceway study in fall 1993 and spring 1994 allowed for sampling of mouth, skin, nare, and vent mucus lysozyme from coho salmon at Willard NFH and spring chinook salmon at Little White Salmon NFH. Mouth mucus samples were difficult to collect and were discontinued after the initial sampling attempt. Because mean mouth mucus lysozyme concentrations did not differ between control and covered groups in either Willard coho salmon or Little White Salmon spring chinook salmon (Appendix L2), data were pooled by sample date. There was no significant difference between mean mouth mucus lysozyme in coho salmon $\left(86 \pm 9 \mu \mathrm{g} \cdot \mathrm{mL}^{-1}\right)$ and spring chinook salmon $\left(106 \pm 9 \mu \mathrm{g} \cdot \mathrm{mL}^{-1}\right)$.

Skin, nare, and vent mucus lysozyme concentrations were determined on five dates prior to release of coho salmon from Willard NFH (Figure 1). There were no significant differences between control and covered treatment groups on a particular date for any of the mucus types sampled (Appendices O2, O3, O4, and O5), and control and covered lysozyme values were pooled by date to determine mean concentrations for reference levels. Lysozyme activity for all three mucus types decreased significantly from February to early March $(P \leq 0.05)$, with a further decrease in nare mucus in mid-April when the fish were released (Table 5).

Skin mucus lysozyme levels in juvenile spring chinook salmon from Little White Salmon NFH declined significantly between February and March $(P \leq 0.05)$, and remained low until the release date in April (Figure 2, Table 6, Appendix O6). Nare mucus lysozyme concentrations differed significantly between February and March $(P \leq 0.05)$, and between early and late March $(P \leq 0.05)$, and continued to decline through the release in April (Figure 2, Table 6, Appendix O7). Vent mucus lysozyme levels decreased steadily from December through April, the difference 
between December and April concentrations being significant $(P \leq 0.05)$ (Figure 2, Table 6, Appendix 08).

Coho salmon and spring chinook salmon mucus lysozyme levels were compared by sample date. There was no significant difference between skin lysozyme concentrations on any sample date, although in January the mean for spring chinook salmon $\left(127 \mu \mathrm{g} \cdot \mathrm{mL}^{-1}\right)$ was twice that of coho salmon $\left(66 \mu \mathrm{g} \cdot \mathrm{mL}^{-1}\right)$. Nare mucus lysozyme concentrations differed significantly $(P \leq$ 0.05), on a single date, March 3, 1994, when levels for spring chinook levels were higher than levels for coho salmon. Mean vent mucus lysozyme levels did not differ between the species at any time during the study.

\section{Disease Challenge Experiments 1993 Results}

Plasma lysozyme concentrations from BKD-challenged fish in 1993 differed significantly from control fish in the 9 th week after the second challenge $(P \leq 0.05)$ (Appendix O9). At this time, plasma lysozyme concentrations had reached their lowest levels in both control and diseasechallenged fish (Figure 3), with disease-challenged fish having lower concentrations. The precipitous drop in concentration 9 weeks after the challenge (October 26, 1993) was experienced by both groups of fish, with a mean of $7.4 \mu \mathrm{g} \cdot \mathrm{mL}^{-1}$ for the control group, and $2.3 \mu \mathrm{g} \cdot \mathrm{mL}^{-1}$ for the challenged group. No significant difference was found in plasma concentrations between the control and challenged groups on the other sample dates. Mean plasma lysozyme concentrations ranged from 19.7 to $24.3 \mu \mathrm{g} \cdot \mathrm{mL}^{-1}$ in the 6th (October 5, 1993), 12th (November 16, 1993), and 15th week (December 9, 1993). At 15 weeks after the disease challenge and five weeks after the stress treatment, the mean plasma lysozyme concentration was higher in the disease-challenged fish.

Changes in skin mucus lysozyme concentrations varied in tandem for the control and disease-challenged fish (Figure 4, Appendix O10). Significant differences between the two groups were found in the 9th (October 26, 1993) and 17th (December 21, 1993) weeks after the second challenge $(P \leq 0.05)$. As with plasma lysozyme, skin mucus lysozyme in control fish was significantly higher than that of diseased fish in the 9 th week $(P \leq 0.05)$. By the 17 th week, skin mucus lysozyme in the disease group $\left(1520 \pm 164 \mu \mathrm{g} \cdot \mathrm{mL}^{-1}\right)$ was twice that of the controls (771 $\left.\pm 68 \mu \mathrm{g} \cdot \mathrm{mL}^{-1}\right)$. Wide variation in mean skin mucus lysozyme was seen during the experiment, with values ranging from a low of $35 \mu \mathrm{g} \cdot \mathrm{mL}^{-1}$ to a high of $1520 \mu \mathrm{g} \cdot \mathrm{mL}^{-1}$.

A significant difference between vent mucus lysozyme in the two treatments was seen one week after the first challenge (June 10, 1993), when the level in disease-challenged fish was over three times as high as the level in control fish $(P \leq 0.05)$. By 6 weeks (July 1, 1993), lysozyme in both groups was almost equal. Vent mucus lysozyme levels declined in both groups, with no further differences being found between the two groups on any date (Figure 5, Appendix O11). Mean vent mucus lysozyme ranged from the peak at 6 weeks after the first challenge, at $1473 \pm$ $64 \mu \mathrm{g} \cdot \mathrm{mL}^{-1}(N=9)$, to a low of $258 \pm 38 \mu \mathrm{g} \cdot \mathrm{mL}^{-1}(N=20)$ in the final sample, 17 weeks after the second challenge. Vent mucus lysozyme continued to decline, while both plasma and skin mucus lysozyme levels increased to their highest levels after the stress treatment. 


\section{Results}

In 1994, fish were disease-challenged once after an initial sample was taken (May 31, 1994). Skin mucus lysozyme levels showed a general increase, with significantly higher concentrations in August than in May and June $(P \leq 0.05)$ (Figure 6) (Appendix O12). There was no significant difference in skin mucus lysozyme levels until ten weeks after the challenge, when the level in disease-challenged fish was three times that of the controls. Mean skin mucus lysozyme of the challenged group was higher on every date with the exception of the last sample, the difference becoming more marked as the disease progressed.

Nare mucus lysozyme levels were the same in the two groups prior to the challenge, but post-challenge levels in control fish remained constant until week 4 , then declined. Levels in both groups declined between weeks 4 and 6 post-challenge. The challenged group experienced a decline soon after the challenge, but lysozyme increased to levels exceeding that of controls, and the two groups were significantly different at week $10(P \leq 0.05)$. By week 12 , levels in challenged fish were similar to those of the controls (Figure 7, Appendix O13).

Vent mucus lysozyme showed a gradual increase over the course of the experiment, with levels in disease-challenged fish being higher in the 8th and 10th week of the infection, as was the case with both skin and nare levels (Figure 8, Appendix O14). Vent mucus lysozyme concentrations of challenged fish were significantly higher $(P \leq 0.05)$, in August than in May or June.

Eight weeks after the challenge, mucus lysozyme concentrations were significantly higher in challenged fish than in control fish for all three mucus types. By 12 weeks, lysozyme levels of controls and treatments were equal.

\section{DISCUSSION}

Mucus lysozyme concentrations in juvenile Pacific salmon revealed consistency among species and hatchery groups. Plasma and serum lysozyme concentrations were low $(\leq 25 \mu \mathrm{g}$. $\mathrm{mL}^{-1}$ ) compared to mucus lysozyme levels, an observation consistent with the literature (Lie et al. 1989). Skin, vent, and nare lysozyme concentrations of control or healthy fish varied within marked ranges. Skin lysozyme was the lowest of the mucus lysozymes, usually under $100 \mu \mathrm{g}$. $\mathrm{mL}^{-1}$. Vent mucus lysozyme ranged from 100 to $400 \mu \mathrm{g} \cdot \mathrm{mL}^{-1}$, and nare mucus lysozyme ranged from 300 to $600 \mu \mathrm{g} \cdot \mathrm{mL}^{-1}$. Previously reported levels for blood and tissue lysozyme were performed by a lysoplate method (Ellis 1990). We found this method unsuitable for assaying small mucus lysozyme samples, and established a microassay plate turbidimetric method.

Skin mucus levels in our study were less than or equal to kidney lysozyme in other marine fish species determined using another turbidimetric method (Grinde et al. 1988b). The highest mucus lysozyme levels we observed in any mucus, even in diseased fish, did not reach concentrations reported in the kidney of other salmonids (Lie et al. 1989). Ranges of plasma, serum, skin, nare, and vent mucus lysozyme were consistent among the species we considered, and were comparable to previous studies assaying lysozyme in tissues of marine fishes (Fange et al. 1976). The interspecies comparisons we made revealed that juvenile spring and summer chinook salmon and coho salmon appeared to have similar mucus lysozyme concentration ranges. 


\section{Baseline Levels in Hatchery Reference Stocks}

\section{Juvenile Salmon}

Uniformity of nare lysozyme levels among hatcheries comparing spring and summer chinook salmon suggests that the mean nare lysozyme levels sampled at release may represent basal concentrations for the reference hatchery populations at that time of year. Rearing temperature did not appear to affect lysozyme level (Appendix O15). Mean nare mucus lysozyme levels ranged from $327 \mu \mathrm{g} \cdot \mathrm{mL}^{-1}$ in Wells Hatchery summer chinook, to $588 \mu \mathrm{g} \cdot \mathrm{mL}^{-1}$ in Lookingglass Hatchery spring chinook salmon.

The similarity of lysozyme ranges in groups of fish reared in close geographic proximity suggests that environmental factors may influence basal lysozyme concentrations. The highest levels of lysozyme (> $480 \mu \mathrm{g} \cdot \mathrm{mL}^{-1}$ ) were found in the lower Snake River tributaries at Lookingglass, Rapid River, and Dworshak hatcheries. Mid-Columbia River spring chinook salmon showed intermediate mean levels of $420 \mu \mathrm{g} \cdot \mathrm{mL}^{-1}$ and $459 \mu \mathrm{g} \cdot \mathrm{mL}^{-1}$ at Winthrop NFH and Entiat NFH, respectively. Hatcheries at or below the confluence of the Columbia and Snake rivers had low mean nare mucus lysozyme levels $\leq 360 \mu \mathrm{g} \cdot \mathrm{mL}^{-1}$ (Ringold Hatchery, Willard NFH, and Little White Salmon NFH). Summer chinook salmon had nare mucus lysozyme levels in the low range $\left(<400 \mu \mathrm{g} \cdot \mathrm{mL}^{-1}\right)$. If the assumption is made that all spring chinook salmon groups were at the same level of smoltification when released, then geographic differences may reflect either stock-specific differences, or differences in environmental factors associated with hatchery rearing practices. Summer chinook salmon were released at the same time of year as their spring chinook salmon counterparts, but did not have comparable lysozyme levels at release. Because rearing conditions were not as uniform across reference hatcheries as in the comparison between Willard NFH coho and Little White Salmon NFH spring chinook salmon, observed differences could conceivably be attributed to variation in rearing environment.

Few conclusions may be drawn from a single sample at release. The two hatcheries with the highest mucus lysozyme levels, Lookingglass and Rapid River, were both stocked with Rapid River spring chinook salmon in 1994. The uniformity of results between hatcheries with the same fish stock, and within geographic regions, consistent with ranges of nare mucus lysozyme we observed in the experiments, suggests that baseline levels of lysozyme may exist in Pacific salmon stocks. A more detailed evaluation of rearing conditions may help to distinguish genetic from environmental determinants of mucus lysozyme levels.

\section{Adult Salmon}

Agreement of the various lysozyme levels in juvenile salmon between stocks, species, hatcheries and years renders them useful as a reference for results from returning adults. Adult serum and secondary circulation lysozyme levels were within cited literature ranges for plasma and serum lysozyme. Inconsistent changes in serum, secondary circulation, skin mucus lysozyme, and vent mucus lysozyme during holding require more extensive investigation. Decreases in mucus cell concentrations during spawning have been reported in brown trout for adult males, but not females (Pickering and Richards 1980). We saw no significant difference in mucus lysozyme concentrations between male and female spring chinook salmon. More frequent and uniform sampling would be necessary to determine if the ranges of serum, secondary circulation, and mucus lysozyme we observed in two groups of adult hatchery spring chinook salmon are 
representative of levels for other returning adults. Changes in lysozyme levels of adult salmon during holding indicate that physiological changes during life history events such as spawning may be accompanied by concurrent changes in lysozyme concentration.

\section{Experimental Fish from Covered and Uncovered Hatchery Raceways}

We documented seasonal changes in lysozyme concentration in skin, nare, and vent mucus in both spring chinook salmon and coho salmon, and observed a decrease at the time the stocks are reported to smolt. The periodic changes we observed were compatible with a previous study documenting reduced lysozyme concentrations in winter and during smoltification in Atlantic salmon and sea trout Salmo trutta (Muona and Soivio 1992). Significant differences were found among mean mucus lysozyme concentrations, by sample date, between December and April in our study. Levels were tested at a time of year when juvenile salmon may have experienced suppressed immune competence (Maule et al. 1987), and we associate the decline in lysozyme levels with smoltification.

A comparison of coho salmon and spring chinook salmon held at Willard NFH and Little White Salmon NFH suggests no difference in baseline levels of mucus lysozyme between the two species. The hatcheries were fed by the same river, and were stocked under loading densities of 3 $\mathrm{kg} \cdot \mathrm{m}^{-3}$, therefore important rearing variables were the same. On one sample date a significant difference was found between nare lysozyme concentrations of coho salmon and spring chinook salmon, but the difference did not persist over the season. In general, mean mucus lysozyme levels of spring chinook salmon were slightly higher than those of coho salmon in the spring before release. Differences on individual sample dates may be a reflection of differences in the level of physiological development of the two species at the time of sampling. The decline in mucus lysozyme levels in juvenile salmon, at the time associated with the parr-to-smolt transformation, is consistent with previously documented changes in lysozyme and physiological and non-specific immune factors during smoltification (Muona and Soivio 1992; Folmar and Dickhoff 1981; Barron 1986; Bradley and Rourke 1988; Maule et al. 1993). Ranges of plasma lysozyme in juvenile coho salmon and chinook salmon were comparable to levels found in Atlantic salmon and sea trout (Muona and Soivio 1992).

\section{Disease Challenge Experiments}

Mucus lysozyme concentrations changed during disease episodes of BKD following challenge with $R$. salmoninarum. The dramatic rise in skin lysozyme levels after exposure to $R$. salmoninarum has not been previously reported, but increases in lysozyme have been documented in fish challenged with Aeromonas salmonicida (Moyner et al. 1993).

The BKD-challenged group experienced a five-fold increase in skin mucus lysozyme between the 12th and 17th week of the disease challenge in 1993, a change that did not manifest itself until after the stress exposure. The stress exercise may have initiated a more severe manifestation of the disease in fish that were in a chronic state of infection prior to the stress episode. Vent mucus lysozyme was significantly different between the groups shortly after disease challenge, but the difference did not persist. Differences in the timing of peaks in lysozyme activity during disease episodes may result from differences in mode of infection of specific pathogens. 
In 1994, skin mucus lysozyme increased between the 8th and the 10th week, when the disease-challenged group had significantly higher levels than control fish. The evident, though less pronounced, increase in lysozyme of the control group indicated the onset of a disease episode in a stock of fish that routinely experiences outbreaks of BKD (Matt Mesa, Columbia River Research Laboratory, personal communication). Nare lysozyme results were significantly different at 8 and 10 weeks post-challenge, with levels in the disease-challenged group higher than in the control group. Vent mucus lysozyme levels were also higher in the 8th and 10th week in the disease-challenged group. Results in 1994 were not complicated by a second disease challenge or by the additional stress treatment. A disease outbreak in the control group in 1994 was evidenced by an increase in mucus lysozyme levels of all three mucus types in the controls to the same levels found in the disease-challenged fish.

The difference in timing of significant increases in lysozyme concentration after disease challenge between the two experiments may be due to differences in time of year when the experiments took place. Our results from spring chinook salmon at Little White Salmon NFH suggest that we must consider the influence of seasonal changes in lysozyme levels on the comparison of experiments conducted at different times of year. Differences in skin, nare, and vent mucus lysozyme levels at different times after the BKD challenge may therefore be attributed to the effects of the experimental disease challenge, superimposed upon seasonal patterns of lysozyme concentration. Differences in lysozyme levels between the two treatment groups occurred at a time consistent with reports of the onset of signs of BKD and mortality after challenge with $R$. salmoninarum (Fryer and Sanders 1981). Rainbow trout lysozyme has been found to be bactericidal to Yersinia ruckeri, Vibrio anguillarum, Vibrio salmonicida, and $A$. salmonicida (Grinde 1989), but lysozyme has not been found to lyse $R$. salmoninarum. Increases in mucus lysozyme levels during bacterial kidney disease episodes may be the result of local tissue involvement during initial exposure to the pathogen, compromise of the kidney during advanced stages of the disease, or localized production of lysozyme when the disease progresses to the stage of tissue involvement and lesions. Previous studies, identifying eosinophilic cells in the epidermis (Pickering and Richards 1980) and eosinophilic granule cells in the intestines of Atlantic salmon as sites where lysozyme has been localized (Sveinbjørnsson et al. 1996), help to explain the dynamics of lysozyme concentration changes as pathogens invade the fish and infection spreads. Differences in the time of year would presuppose seasonal differences in lysozyme levels (Muona and Soivio 1992), differences in the immune competence of the fish (Maule et al. 1987), and differences in pathogenicity of the bacteria (Chavessus and Dorson 1990). The determination of baseline annual profiles of mucus lysozyme activity in the reference stocks would be desirable to allow comparisons with and evaluations of mucus lysozyme levels under different rearing or experimental conditions.

\section{Conclusions}

Mucus lysozyme determination has the potential to be a useful, non-lethal measurement of the health and physiological status of both juvenile and adult Pacific salmon. The consistency of concentration ranges of skin, nare, and vent mucus lysozyme levels supports evidence for the genetic basis of lysozyme variation seen in other species (Røed et al. 1990, 1993). Repetitive seasonal patterns of change in lysozyme concentrations, especially during the period associated with smoltification, provide strong physiological evidence of changing patterns of disease 
resistance and immunity during life history events. Because mucus lysozyme has not been extensively studied, our results provide a valuable reference for future studies of both juvenile and adult salmon. We determined that mucus levels in both adults and juveniles were comparable to levels found in rainbow trout and Atlantic salmon (Grinde et al. 1988b). Mucus lysozyme levels usually exceeded plasma or serum lysozyme levels, with concentrations ranging from 10 to 2000 $\mu \mathrm{g} \cdot \mathrm{mL}^{-1}(\mathrm{HEWL})$.

Mucus lysozyme level may prove to be a useful tool for assessing the health of juvenile and adult salmon during smoltification, spawning, and disease episodes. Mucus samples collected by inoculation loop provided concentrations appropriate for analysis by a turbidimetric method. In fish considered healthy (controls or hatchery stocks), nare mucus lysozyme concentrations were the highest, followed by vent mucus, skin mucus, and serum or plasma mucus.

The effects of stress on lysozyme concentrations have been noted (Murray and Fletcher 1976; Mock and Peters 1990), and stress may have been the source of some variability in lysozyme concentrations for adult salmon. Stress has been implicated as the initiator of more acute infection, with an accompanying increase in mucus lysozyme levels. A significant increase in skin mucus lysozyme in disease-challenged fish in 1993 may have been promoted by stress acting to transform a chronic infection into an acute infection.

Uniform sampling of juvenile Pacific salmon provided mucus lysozyme results with a level of consistency that promises to prove useful in assessing fish health. With the establishment of baseline levels for specific stocks, and an understanding of the effects of genetics, environment, stress, and physiology on lysozyme levels, a clearer understanding of disease resistance and its contribution to fish health may be realized. 
CHAPTER THREE TABLES 
Table 1. Mean $( \pm \mathrm{SE})$ nare mucus lysozyme concentration $\left(\mu \mathrm{g} \cdot \mathrm{mL}^{-1}\right)$, release date, and sample size $(N)$ of juvenile chinook salmon released from Columbia and Snake River basin hatcheries in 1994. Means with the same letter differ significantly $(P \leq 0.05)$ ( $\mathrm{SPCH}=$ spring chinook salmon; SUCH = summer chinook salmon; NFH = National Fish Hatchery; SFH = State Fish Hatchery).

\begin{tabular}{lcllc}
\hline \multicolumn{1}{c}{ Hatchery } & $\underline{\text { Release }}$ & $\underline{\text { Species }}$ & $\underline{N}$ & $\begin{array}{l}\text { Lysozyme Concentration } \\
\left(\mu \mathrm{g} \cdot \mathrm{mL}^{-1} \mathrm{HEWL}\right)\end{array}$ \\
\hline Dworshak NFH & $3 / 2 / 94$ & SPCH & 14 & $392(26)$ \\
Dworshak NFH & $3 / 15 / 94$ & SPCH & 48 & $482(31)$ \\
Sawtooth SFH & $3 / 29 / 94$ & SPCH & 48 & $363(40) \mathrm{a}$ \\
McCall SFH & $3 / 30 / 94$ & SUCH & 46 & $382(44) \mathrm{b}$ \\
Rapid River SFH & $3 / 30 / 94$ & SPCH & 55 & $531(52)$ \\
Ringold SFH & $3 / 28 / 94$ & SPCH & 57 & $357(23) \mathrm{c}$ \\
Entiat NFH & $3 / 29 / 94$ & SPCH & 58 & $459(31)$ \\
Lookingglass SFH & $3 / 30 / 94$ & SPCH & 60 & $588(27) \mathrm{abcd}$ \\
Winthrop NFH & $4 / 11 / 94$ & SPCH & 57 & $420(28)$ \\
Wells SFH & $4 / 12 / 94$ & SUCH & 22 & $276(22) \mathrm{d}$ \\
\hline
\end{tabular}


Table 2. Mean $( \pm \mathrm{SE})$ plasma and secondary circulation lysozyme concentrations in adult chinook salmon returning to Carson National Fish Hatchery in $1993(N=$ sample size $)$. Means with the same letter differ significantly $(P \leq 0.05)$.

\begin{tabular}{lccc}
\hline \multicolumn{1}{c}{ Tissue } & $\underline{\mathrm{N}}$ & $\begin{array}{c}\text { Lysozyme } \\
\text { Concentration }\end{array}$ \\
& $6 / 17 / 93$ & 8 & $\left.24.8(2.7) \mathrm{a} \cdot \mathrm{mL}^{-1} \mathrm{HEWL}\right)$ \\
\hline Plasma & $8 / 10 / 93$ & 14 & $13.6(0.8) \mathrm{a}$ \\
Secondary Circulation & $6 / 17 / 93$ & 14 & $26.3(0.6)$ \\
& $8 / 10 / 93$ & 17 & $24.6(1.2)$ \\
\hline
\end{tabular}


Table 3. Mean $( \pm \mathrm{SE})$ serum, secondary circulation, skin mucus, and vent mucus lysozyme concentrations in adult chinook salmon returning to Carson National Fish Hatchery in $1994(N=$ sample size). Means with the same letter differ significantly $(P \leq 0.05)$.

\begin{tabular}{|c|c|c|c|}
\hline$\underline{\text { Tissue }}$ & $\underline{\text { Sample date }}$ & $\underline{N}$ & $\begin{array}{c}\frac{\text { Lysozyme }}{\text { Concentration }} \\
\left(\mu \mathrm{g} \mathrm{mL}{ }^{-1} \mathrm{HEWL}\right)\end{array}$ \\
\hline \multirow[t]{6}{*}{ Serum } & 8/8/94 & 35 & $13.0(1.4) \mathrm{ab}$ \\
\hline & $8 / 15 / 94$ & 40 & $14.5(1.2) \mathrm{cd}$ \\
\hline & $8 / 22 / 94$ & 40 & 13.5 (1.1)ef \\
\hline & $8 / 29 / 94$ & 41 & $6.9(0.7) \mathrm{aceg}$ \\
\hline & $9 / 2 / 94$ & 40 & $15.3(0.4) \mathrm{bgh}$ \\
\hline & 9/7/94 & 40 & $5.6(0.6)$ bdfh \\
\hline \multirow[t]{6}{*}{ Secondary Circulation } & $8 / 8 / 94$ & 34 & $20.1(0.6) \mathrm{ij}$ \\
\hline & $8 / 15 / 94$ & 40 & $18.4(0.4) \mathrm{kl}$ \\
\hline & $8 / 22 / 94$ & 39 & $20.2(0.4) \mathrm{mn}$ \\
\hline & $8 / 29 / 94$ & 39 & 10.4 (0.8)ikmo \\
\hline & $9 / 2 / 94$ & 39 & $19.1(0.4)$ op \\
\hline & 9/7/94 & 40 & $8.1(0.8) j \ln p$ \\
\hline \multirow[t]{3}{*}{ Skin } & $8 / 8 / 94$ & 36 & $58(4)$ \\
\hline & $8 / 15 / 94$ & 40 & $59(6)$ \\
\hline & $8 / 29 / 94$ & 41 & $52(2)$ \\
\hline \multirow[t]{3}{*}{ Vent } & $8 / 15 / 94$ & 26 & $785(82)$ \\
\hline & $8 / 22 / 94$ & 27 & $701(40)$ \\
\hline & $9 / 2 / 94$ & 27 & $759(30)$ \\
\hline
\end{tabular}


Table 4. Mean $( \pm$ SE) serum, secondary circulation, and skin mucus lysozyme concentrations in adult chinook salmon returning to Little White Salmon National Fish Hatchery in $1994(N=$ sample size).

\begin{tabular}{lccc}
\hline \multicolumn{1}{c}{ Tissue } & $\underline{\mathrm{N}}$ & $\begin{array}{c}\text { Lysozyme } \\
\text { Concentration } \\
\left(\mu \mathrm{g} \cdot \mathrm{mL}^{-1} \mathrm{HEWL}\right)\end{array}$ \\
\hline Serum & $7 / 27 / 94$ & 33 & $5.2(0.8)$ \\
& $8 / 3 / 94$ & 26 & $7.4(1.0)$ \\
Secondary Circulation & $7 / 27 / 94$ & 36 & $17.8(1.0)$ \\
& $8 / 3 / 94$ & 38 & $17.8(0.4)$ \\
Skin & $7 / 27 / 94$ & 36 & $74(15)$ \\
& $8 / 3 / 94$ & 40 & $60(4)$ \\
\hline
\end{tabular}


Table 5. Mean $( \pm \mathrm{SE})$ skin, nare, and vent mucus lysozyme concentrations in juvenile coho salmon used in raceway cover experiments at Willard National Fish Hatchery, 1993-1994 ( $N=$ sample size). Means with the same letter differ significantly $(P \leq 0.05)$.

\begin{tabular}{|c|c|c|c|}
\hline$\underline{\text { Tissue }}$ & $\underline{\text { Sample Date }}$ & $\underline{\mathrm{N}}$ & $\frac{\text { Lysozyme }}{\text { Concentration }}$ \\
\hline \multirow[t]{4}{*}{ Skin } & $2 / 2 / 94$ & 60 & 66 (3)abc \\
\hline & $3 / 3 / 94$ & 59 & $30(2) \mathrm{ad}$ \\
\hline & $3 / 24 / 94$ & 59 & 18 (3)bd \\
\hline & $4 / 18 / 94$ & 58 & $26(3) c$ \\
\hline \multirow[t]{5}{*}{ Nare } & $12 / 21 / 93$ & 9 & $364(61) \mathrm{e}$ \\
\hline & $2 / 2 / 94$ & 59 & 584 (25)efgh \\
\hline & $3 / 3 / 94$ & 59 & 421 (18)f \\
\hline & $3 / 24 / 94$ & 37 & $371(26) \mathrm{g}$ \\
\hline & $4 / 18 / 94$ & 56 & 331 (16)h \\
\hline \multirow[t]{5}{*}{ Vent } & $12 / 21 / 93$ & 31 & 319 (35)ijk \\
\hline & $2 / 2 / 94$ & 59 & 245 (16)lm \\
\hline & $3 / 3 / 94$ & 56 & 213 (18)in \\
\hline & $3 / 24 / 94$ & 59 & 141 (10)jln \\
\hline & 4/18/94 & 58 & $151(11) \mathrm{km}$ \\
\hline
\end{tabular}


Table 6. Mean $( \pm$ SE) skin, nare and vent mucus lysozyme concentrations in juvenile spring chinook salmon used in raceway cover experiments at Little White Salmon National Fish Hatchery, 1993-1994 $(N=$ sample size $)$. Means with the same letter differ significantly $(P \leq$ $0.05)$.

\begin{tabular}{|c|c|c|c|}
\hline$\underline{\text { Tissue }}$ & $\underline{\text { Sample Date }}$ & $\underline{N}$ & $\frac{\text { Lysozyme }}{\text { Concentration }}$ \\
\hline \multirow[t]{5}{*}{ Skin } & $12 / 21 / 93$ & 29 & $47(3)$ \\
\hline & $2 / 2 / 94$ & 60 & 127 (37)abc \\
\hline & $3 / 3 / 94$ & 58 & $20(2) a$ \\
\hline & $3 / 24 / 94$ & 60 & $32(3) b$ \\
\hline & $4 / 18 / 94$ & 59 & $29(3) c$ \\
\hline \multirow[t]{5}{*}{ Nare } & $12 / 21 / 93$ & - & - \\
\hline & $2 / 2 / 94$ & 60 & 726 (45)def \\
\hline & $3 / 3 / 94$ & 60 & 584 (35)dgh \\
\hline & $3 / 24 / 94$ & 59 & 387 (25)eg \\
\hline & $4 / 18 / 94$ & 59 & 319 (24)fh \\
\hline \multirow[t]{5}{*}{ Vent } & $12 / 21 / 93$ & 28 & $293(18)$ \\
\hline & $2 / 2 / 94$ & 60 & $287(20) \mathrm{i}$ \\
\hline & $3 / 3 / 94$ & 58 & 247 (43) \\
\hline & $3 / 24 / 94$ & 60 & $200(14)$ \\
\hline & $4 / 18 / 94$ & 58 & 164 (10)i \\
\hline
\end{tabular}




\section{CHAPTER THREE FIGURES}




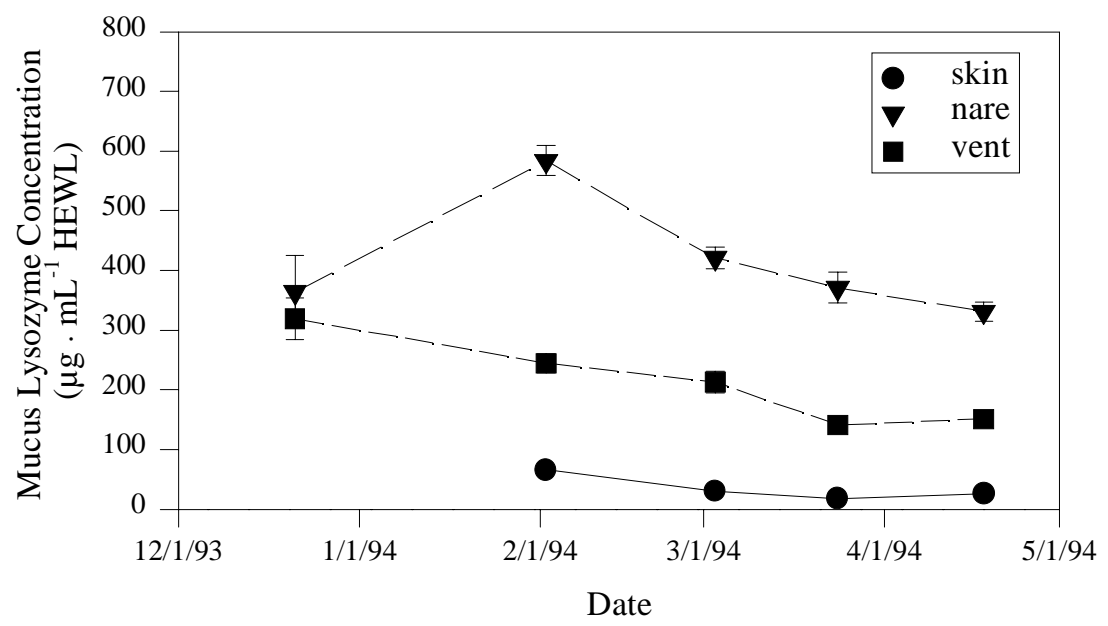

Figure 1. Mean $( \pm$ SE) skin, nare, and vent mucus lysozyme concentrations $\left(\mu \mathrm{g} \cdot \mathrm{mL}^{-1} \mathrm{HEWL}\right)$ in juvenile coho salmon used in raceway cover experiments at Willard National Fish Hatchery, 1993 to 1994. 


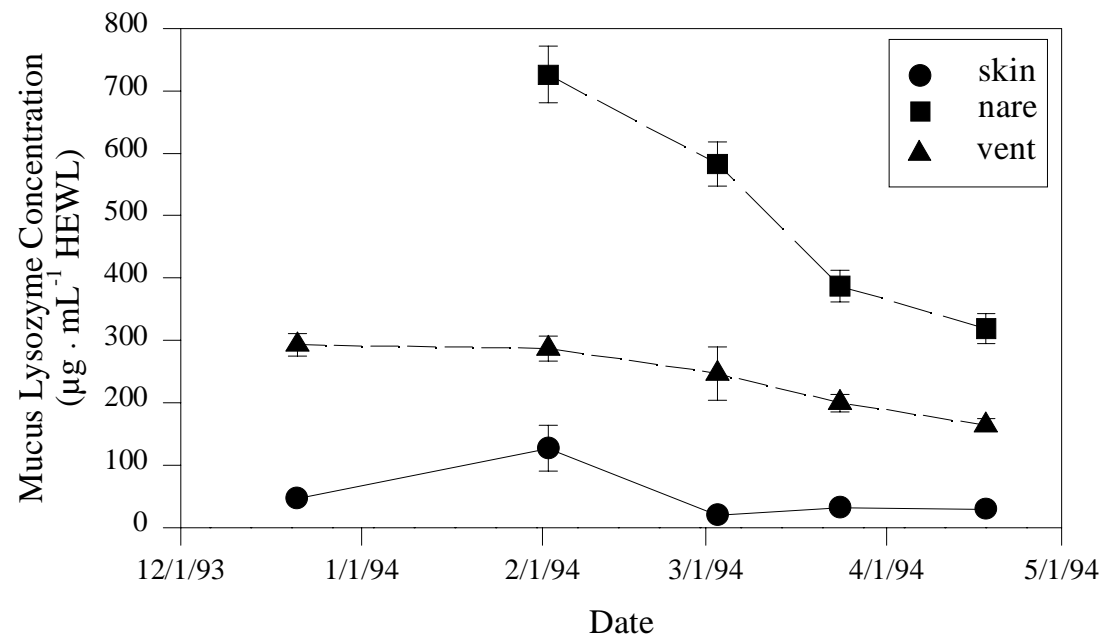

Figure 2. Mean $( \pm \mathrm{SE})$ skin, nare, and vent mucus lysozyme concentrations $\left(\mu \mathrm{g} \cdot \mathrm{mL}^{-1}\right.$ HEWL) of spring chinook salmon used in raceway cover experiments at Little White Salmon National Fish Hatchery, 1993 to 1994. 


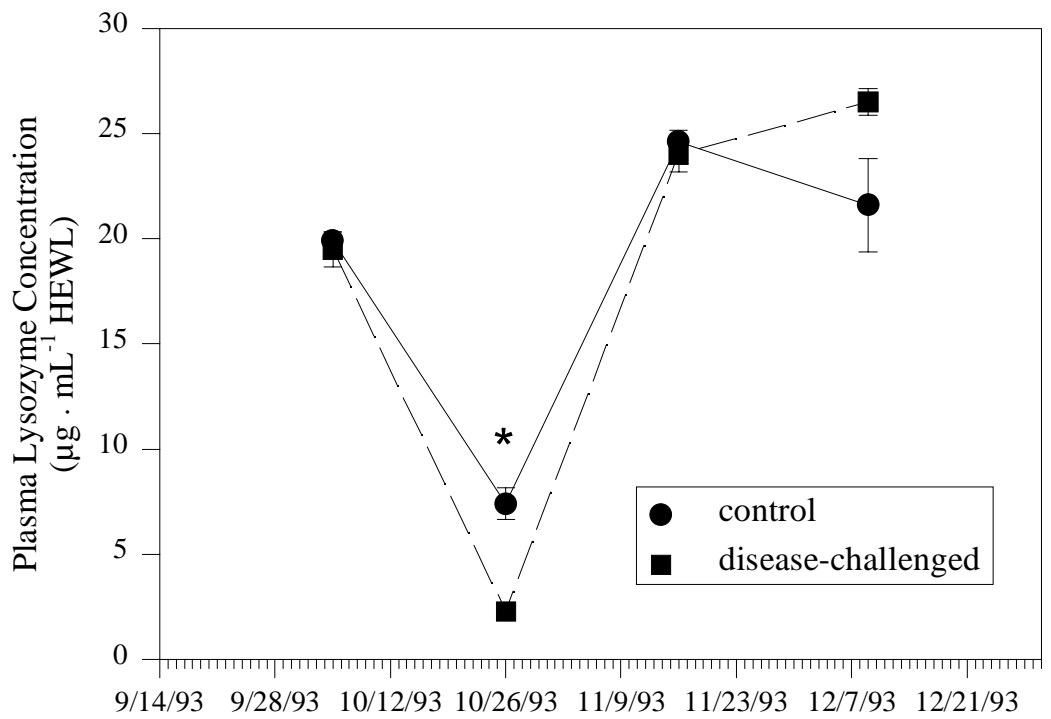

Date

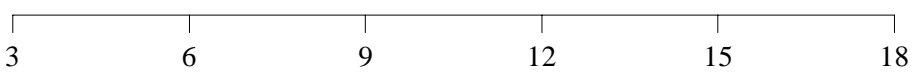

Weeks After 2nd Disease Challenge

Figure 3. Mean $( \pm \mathrm{SE})$ plasma lysozyme concentration $\left(\mu \mathrm{g} \cdot \mathrm{mL}^{-1} \mathrm{HEWL}\right)$ in juvenile spring chinook salmon after challenge with Renibacterium salmoninarum, versus control fish, in 1993. Disease challenges were administered on 5/20/93 and 8/24/93; a stress challenge was administered on 11/16/93. Asterisks mark dates of significant difference between treatment and control groups. 


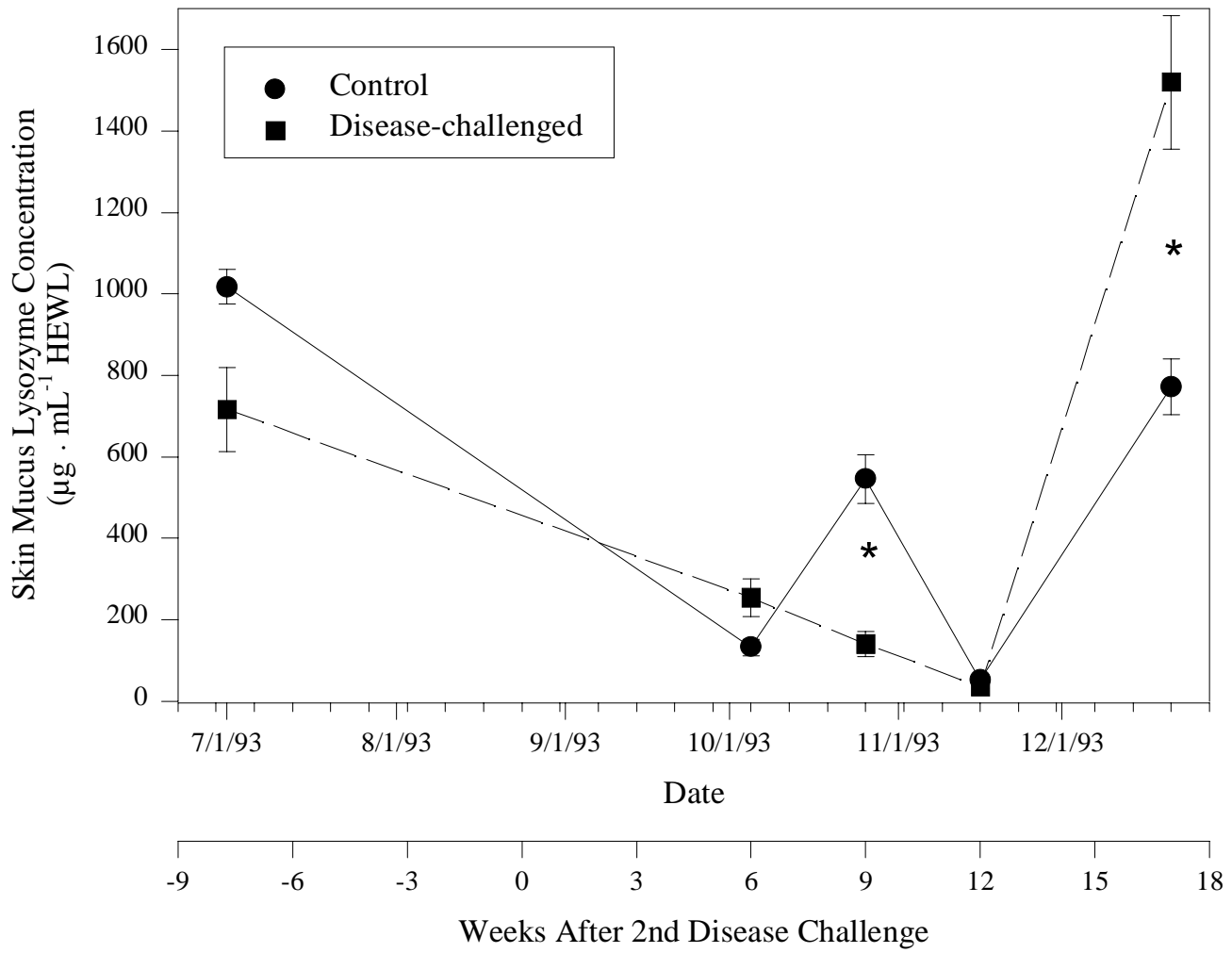

Figure 4. Mean $( \pm \mathrm{SE})$ skin mucus lysozyme concentration $\left(\mu \mathrm{g} \cdot \mathrm{mL}^{-1} \mathrm{HEWL}\right)$ in juvenile spring chinook salmon experimentally challenged with Renibacterium salmoninarum, versus control fish, in 1993. Disease challenges were administered on 5/20/93 and on 8/24/93; a stress challenge was administered on 11/16/93. Asterisks denote dates of significant difference between control and disease-challenged groups. 


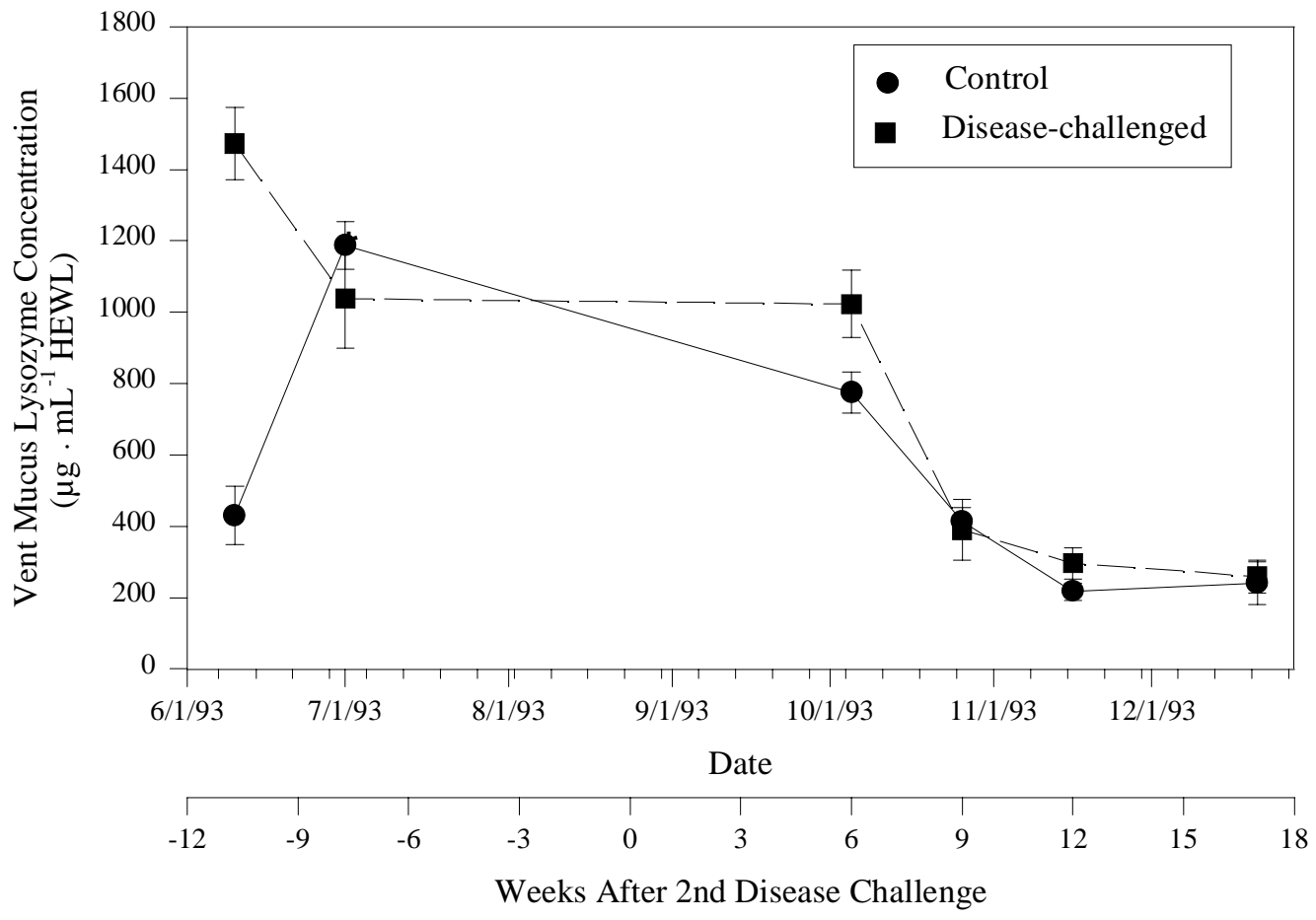

Figure 5. Mean $( \pm \mathrm{SE})$ vent mucus lysozyme concentration $\left(\mu \mathrm{g} \cdot \mathrm{mL}^{-1} \mathrm{HEWL}\right)$ in juvenile spring chinook salmon challenged with exposure to Renibacterium salmoninarum, versus control fish, in 1993. Disease challenges were administered on 5/20/93 and 8/24/93; a stress challenge was administered on 11/16/93. Asterisks mark dates of significant difference between control and treatment groups. 


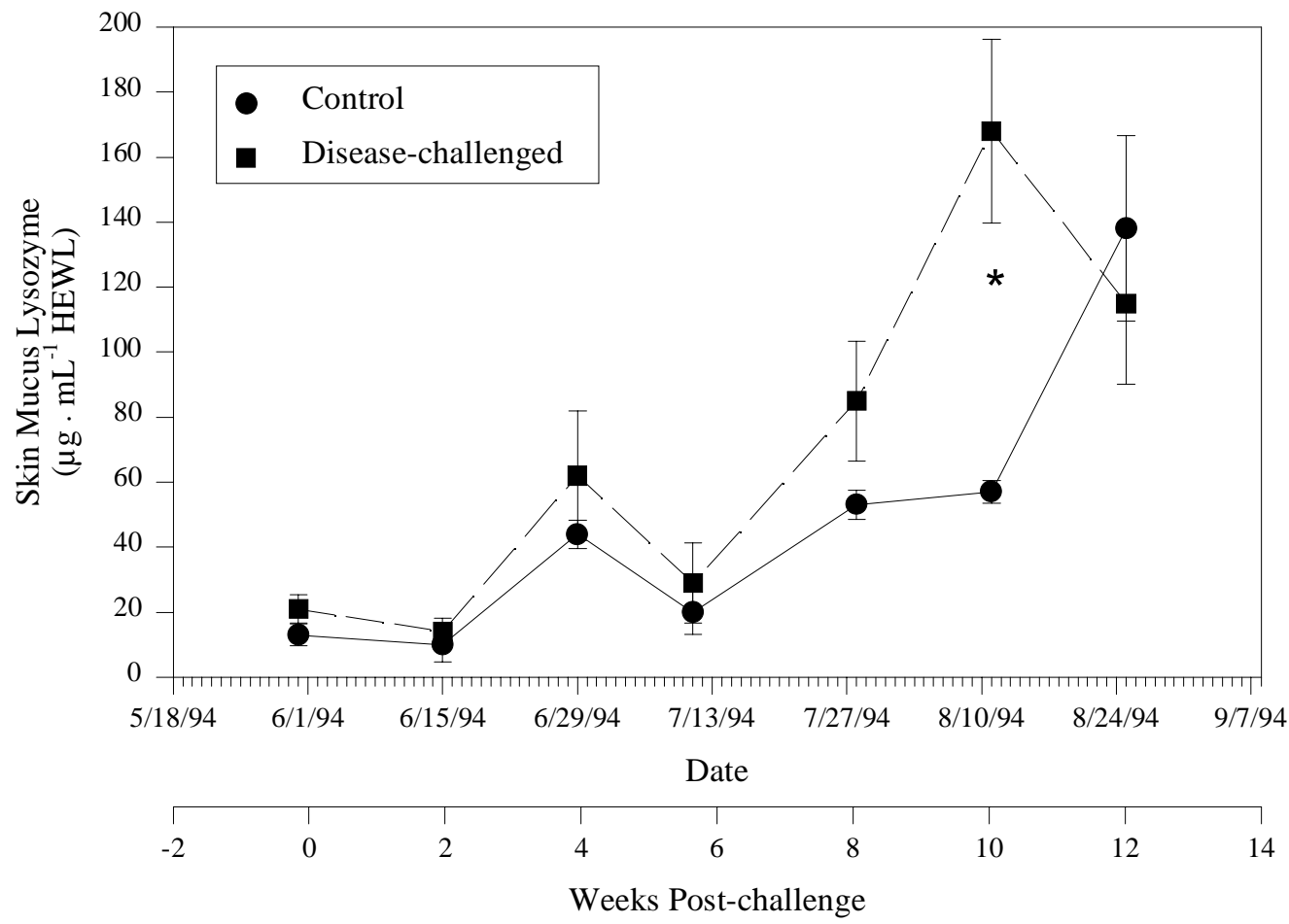

Figure 6. Mean $( \pm \mathrm{SE})$ skin mucus lysozyme concentrations $\left(\mu \mathrm{g} \cdot \mathrm{mL}^{-1} \mathrm{HEWL}\right)$ in juvenile spring chinook salmon challenged with exposure to Renibacterium salmoninarum, versus control fish, in 1994. The disease challenge was administered on 6/1/94. Asterisks mark dates of significant difference between values for treatment and control fish. 


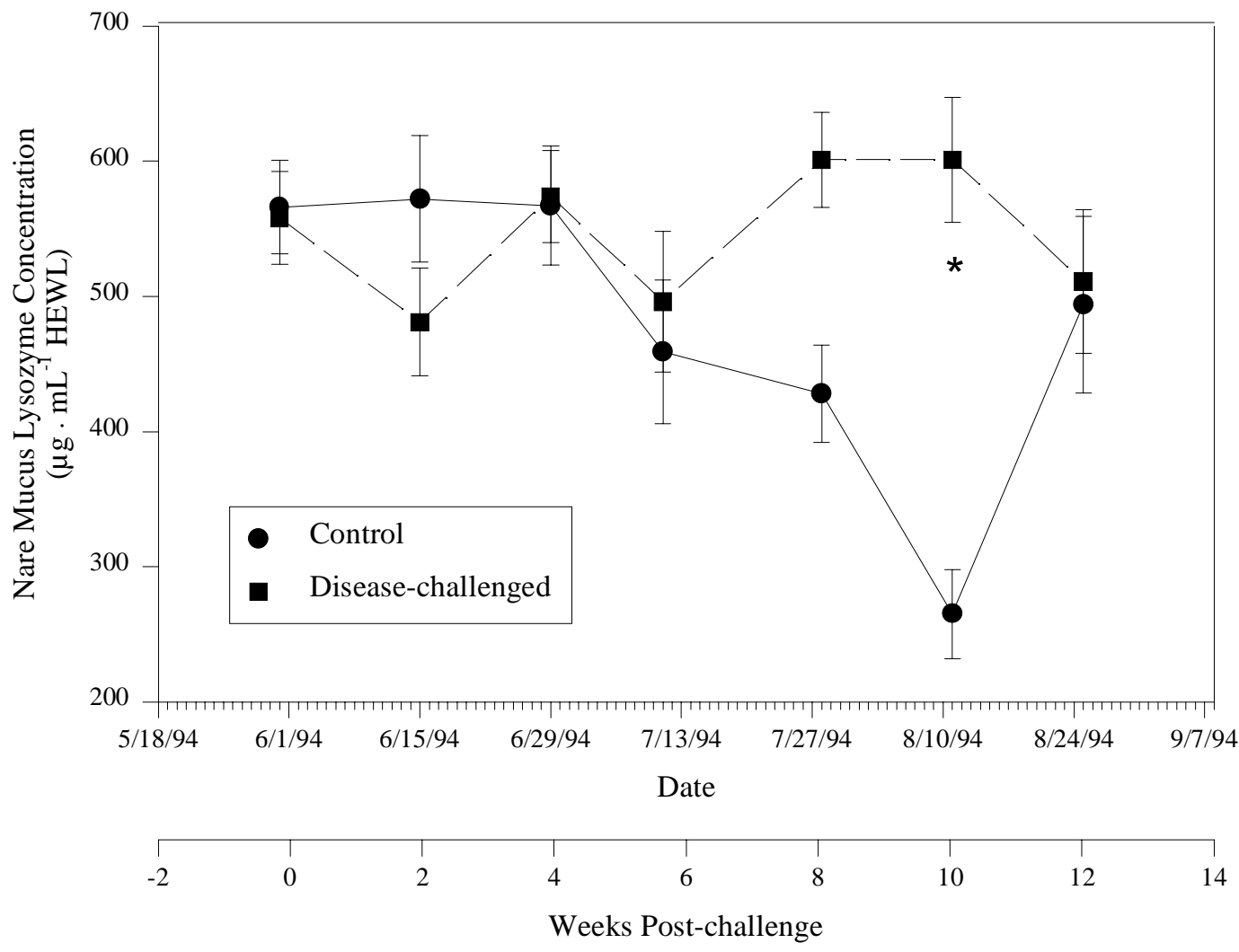

Figure 7. Mean $\left( \pm\right.$ SE) nare mucus lysozyme concentrations $\left(\mu \mathrm{g} \cdot \mathrm{mL}^{-1} \mathrm{HEWL}\right)$ in juvenile spring chinook salmon challenged with Renibacterium salmoninarum, versus control fish, in 1994. The disease challenge was administered on 6/1/94. Asterisks denote significant difference between control and treatment groups. 


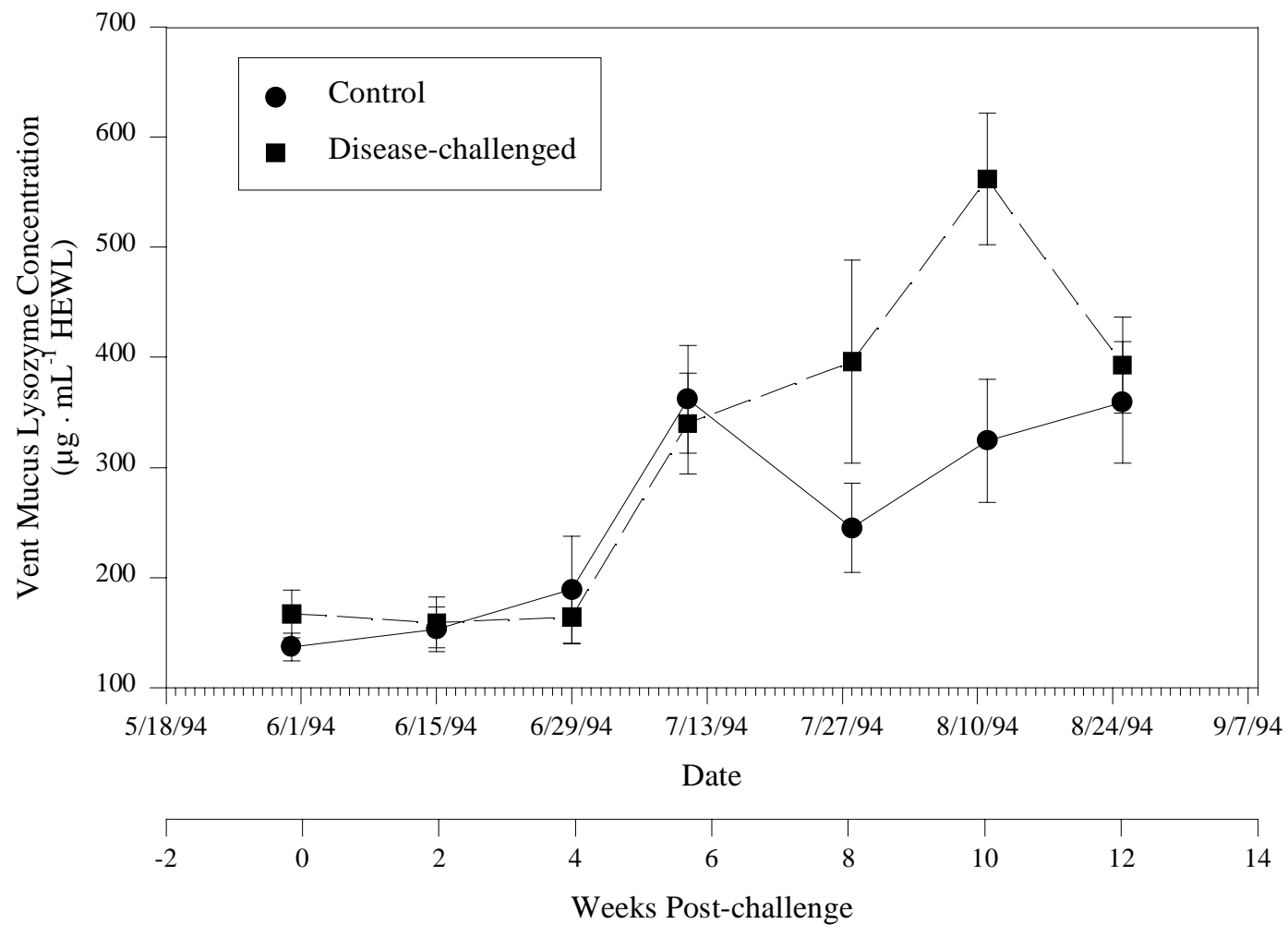

Figure 8. Mean $( \pm \mathrm{SE})$ vent mucus lysozyme concentration $\left(\mu \mathrm{g} \cdot \mathrm{mL}^{-1} \mathrm{HEWL}\right)$ in juvenile spring chinook salmon challenged with exposure to Renibacterium salmoninarum, versus control fish, in 1994. The disease challenge was administered on 6/1/94. 


\section{REFERENCES}

Barron, M. G. 1986. Endocrine control of smoltification in anadromous salmonids. Journal of Endocrinology 108:313-319.

Barton, B. A., C. B. Schreck, R. D. Ewing, A. R. Hemmingsen, and R. Patino. 1985. Changes in plasma cortisol during stress and smoltification in coho salmon, Oncorhynchus kisutch. General and Comparative Endocrinology 59:468-471.

Beeman, J. W., and D. W. Rondorf. 1992. Effects of flow and smoltification on the migration rates of spring chinook salmon and steelhead. Pages 77-83 in Proceedings of the Atlantic Salmon Workshop. U.S. Fish and Wildlife Service, Lamar, Pennsylvania.

Beeman, J. W., D. W. Rondorf, J. C. Faler, M. E. Free, and P. V. Haner. 1990. Assessment of smolt condition for travel time analysis. Annual report 1989 (Contract DE-A17987BP35245) to Bonneville Power Administration, Portland, Oregon.

Beeman, J. W., D. W. Rondorf, J. C. Faler, M. E. Free, P. V. Haner, S. T. Sauter, and D. A. Venditti. 1991. Assessment of smolt condition for travel time analysis. Annual Report 1990 (Contract DE-A179-87BP35245) to Bonneville Power Administration, Portland, Oregon.

Beeman, J. W., D. W. Rondorf, and M. E. Tilson. 1994. Assessing smoltification of juvenile spring chinook salmon (Oncorhynchus tshawytscha) using changes in body morphology. Canadian Journal of Fisheries and Aquatic Sciences 51:836-844.

Beeman, J. W., D. W. Rondorf, M. E. Tilson, and D. A. Venditti. 1995. A non-lethal measure of smolt status of juvenile steelhead based on body morphology. Transactions of the American Fisheries Society 124:764-769.

Borgatti, A. R., A. Pagliari, and V. Ventrella. 1992. Gill $\left(\mathrm{Na}^{+}, \mathrm{K}^{+}\right)$-ATPase involvement and regulation during salmonid adaptation to salt water. Comparative Biochemistry and Physiology 102A:637-643.

Bradley, T. M. and A. W. Rourke. 1988. Smoltification in steelhead trout (Salmo gairdneri): developmental aspects of plasma constituents. Fish Physiology and Biochemistry 5(1):3947.

Chevassus, B. and M. Dorson. 1990. Genetics of resistance to disease in fishes. Aquaculture 85:83-107.

Chipman, D. M. and N. Sharon. 1969. Mechanism of lysozyme action. Science 165:454-465. 
Chu, F-L. E. and J. F. LaPeyre. 1989. Effect of environmental factors and parasitism on hemolymph lysozyme and protein of American lobsters (Crassostrea virginica). Journal of Invertebrate Pathology 54:224-232.

Dautigny, A., E. M. Prager, D. Pham-Dinh, J. Jolles, F. Pakdel, B. Grinde, and P. Jolles. 1991. cDNA and amino acid sequences of rainbow trout (Oncorhynchus mykiss) lysozymes and their implications for the evolution of lysozyme and lactalbumin. Journal of Molecular Evolution 32:187-198.

Davies, R. C., A. Neuberger, and B. M. Wilson. 1969. The dependence of lysozyme activity on $\mathrm{pH}$ and ionic strength. Biochimica et Biophysica Acta 178:294-503.

Dickhoff, W. W., C. Sullivan, and C. V. W. Mahnken. 1985. Methods of measuring and controlling the parr to smolt transformation (smoltification) of juvenile salmon. Pages 5-9 in C. J. Sniderman (ed.), Proceedings of the Eleventh U.S.-Japan Meeting on Aquaculture. U. S. Department of Commerce, National Marine Fisheries Service Technical Report 27, Seattle, Washington.

Ellis, A. E. 1990. Lysozyme Assays. Pages 101-103 in J. S. Stolen, T. C. Fletcher, D. P. Anderson, B. S. Robertson, and W. B. van Muiswinkel (eds.), Techniques in Fish Immunology. SOS Publications, Fair Haven, New Jersey.

Ewing, R. D., C. A. Fustish, S. L. Johnson, and H. J. Pribble. 1980. Seaward migration of juvenile chinook salmon without elevated $\left(\mathrm{Na}^{+}, \mathrm{K}^{+}\right)$-ATPase activities. Transactions of the American Fisheries Society 109:349-356.

Fange, R., G. Lundblad, and J. Lind. 1976. Lysozyme and chitinase in blood and lymphomyeloid tissues of marine fish. Marine Biology 36:277-282.

Fevolden, S. E., T. Refstie, and K. H. Røed. 1991. Selection for high and low cortisol stress response in Atlantic salmon (Salmo salar) and rainbow trout (Oncorhynchus mykiss). Aquaculture 95:53-65.

Fevolden, S. E., T. Refstie, and K. H. Røed. 1992. Disease resistance in rainbow trout (Oncorhynchus mykiss) selected for stress response. Aquaculture 104:19-29.

Fevolden, S. E., K. H. Røed, and B. Gjerde. 1994. Genetic components of post-stress cortisol and lysozyme activity in Atlantic salmon; correlations to disease resistance. Fish and Shellfish Immunology 4:507-519.

Fish Passage Center. 1993. 1992 Annual report to Bonneville Power Administration (Project No. 87-127), Portland, Oregon. 
Fish Passage Center. 1994. 1993 Annual report to Bonneville Power Administration (Project No. 87-127), Portland, Oregon.

Folmar, L. C. and W. W. Dickhoff. 1981. Evaluation of some physiological parameters as predictive of smoltification. Aquaculture 23:309-324.

Franklin, C. E., W. Davison, and M. E. Forster. 1992. Seawater adaptability of New Zealand's sockeye (Oncorhynchus nerka) and chinook salmon (O. tshawytscha): physiological correlates of smoltification and seawater survival. Aquaculture 102:127-142.

Fryer, J. L. and J. E. Sanders. 1981. Bacterial kidney disease of salmonid fish. Annual Review of Microbiology 35:273-298.

Giles, M. A. and W. E. Vanstone. 1976. Changes in ouabain-sensitive adenosine triphosphate activity in gills of coho salmon (Oncorhynchus kisutch) during parr-smolt transformation. Journal of the Fisheries Research Board of Canada 33:54-62.

Grinde, B., J. Jolles, and P. Jolles. 1988a. Purification and characterization of two lysozymes from rainbow trout (Salmo gairdneri). European Journal of Biochemistry 173:269-273.

Grinde, B., Ø. Lie, T. Poppe, and R. Salte. 1988b. Species and individual variation in lysozyme activity in fish of interest in aquaculture. Aquaculture 68:299-304.

Grinde, B. 1989. Lysozyme from rainbow trout, Salmo gairdneri Richardson, as an antibacterial agent against fish pathogens. Journal of Fish Diseases 12:95-104.

Haner, P. V., J. C. Faler, R. M. Schrock, D. W. Rondorf, and A. G. Maule. 1995. Skin reflectance as a non-lethal measure of smoltification for juvenile salmonids. North American Journal of Fisheries Management 15:814-822.

Hoar, W. S. 1976. Smolt transformation: evolution, behavior, and physiology. Journal of the Fisheries Research Board of Canada 33:1233-1252.

Hoar, W. S., and D. J. Randall, eds. 1984. Fish Physiology, Volume X, Part B. New York: Academic Press.

Iwamoto, R. N., W. D. Muir, B. P. Sanford, K. W. McIntyre, D. A. Frost, J. G. Williams, S. G. Smith, and J. R. Skalski. 1994. Survival estimates for the passage of juvenile chinook salmon through Snake River dams and reservoirs, 1993. Annual report (Project No. 9329) to Bonneville Power Administration, Portland, Oregon. 
Jones, R. N., and H. L. Burge. 1993. An evaluation of the effects of release time on the postrelease performance and adult returns of spring chinook salmon at Dworshak and Kooskia National Fish Hatcheries in 1993. Progress Report to Lower Snake River Compensation Plan Office, Idaho Fishery Resource Office, U. S. Fish and Wildlife Service, Ahsahka, Idaho.

Jones, R. N., and H. L. Burge. 1994. An evaluation of the effects of release time on the postrelease performance and adult returns of spring chinook salmon at Dworshak and Kooskia National Fish Hatcheries in 1994. Progress Report to Lower Snake River Compensation Plan Office, Idaho Fishery Resource Office, U. S. Fish and Wildlife Service, Ahsahka, Idaho.

Jonsson, N. 1991. Influence of water flow, water temperature, and light on fish migration in rivers. Nordic Journal of Freshwater Research 66:20-35.

Lie, Ø., O. Evensen, A. Sorensen, and E. Froysadal. 1989. Study on lysozyme activity in some fish species. Diseases of Aquatic Organisms 6:1-5.

Litwack, G. 1955. Photometric determination of lysozyme activity. Proceedings of the Society of Experimental Biology and Medicine 89:401-403.

Maule, A. G., C. B. Schreck, and S. L. Kaattari. 1987. Changes in the immune system of coho salmon (Oncorhynchus kisutch) during the parr-to-smolt transformation and after implantation of cortisol. Canadian Journal of Fisheries and Aquatic Sciences 44:161-166.

Maule, A. G., C. B. Schreck, and C. Sharpe. 1993. Seasonal changes in cortisol sensitivity and glucocorticoid receptor affinity and number in leukocytes of coho salmon. Fish Physiology and Biochemistry 10(6):497-506.

Maule, A. G., J. W. Beeman, R. M. Schrock, and P. V. Haner. 1994. Assessment of smolt condition for travel time analysis. Annual report 1991-1992 (Contract DE-A17987BP35245) to Bonneville Power Administration, Portland, Oregon.

Maule, A. G., D. W. Rondorf, J. W. Beeman, and P. V. Haner. 1996a. Incidence of Renibacterium salmoninarum infections in juvenile hatchery spring chinook salmon in the Columbia and Snake Rivers. Journal of Aquatic Animal Health 8:37-46.

Maule, A. G., R. M. Schrock, C. Slater, M. S. Fitzpatrick, and C. B. Schreck. 1996b. Immune and endocrine responses of adult chinook salmon during freshwater immigration and sexual maturation. Fish and Shellfish Immunology 6:221-233. 
McCartney, T. H. 1976. Sodium-potassium dependent adenosine triphosphatase activity in gills and kidneys of Atlantic salmon (Salmo salar). Comparative Biochemistry and Physiology 53A:351-353.

McCormick, S. D., R. L.Saunders, E. B. Henderson, and P. R. Harmon. 1987. Photoperiod control of parr-smolt transformation in Atlantic salmon (Salmo salar): changes in salinity tolerance, gill $\mathrm{Na}^{+}, \mathrm{K}^{+}$-ATPase activity, and plasma thyroid hormones. Canadian Journal of Fisheries and Aquatic Sciences 44:1462-1468.

McCormick, S. D., R. L.Saunders, and A. D. MacIntyre. 1989. Mitochondrial enzyme and $\mathrm{Na}^{+}$, $\mathrm{K}^{+}$-ATPase activity, and ion regulation during parr-smolt transformation of Atlantic salmon (Salmo salar). Fish Physiology and Biochemistry 6(4):231-241.

Mock, A., and G. Peters. 1990. Lysozyme activity in rainbow trout, Oncorhynchus mykiss (Walbaum), stressed by handling, transport and water pollution. Journal of Fish Biology 37:873-885.

Moyner, K., K. H. Røed, S. Sevatdal, and M. Heum. 1993. Changes in non-specific immune parameters in Atlantic salmon, Salmo salar L., induced by Aeromonas salmonicida. Fish and Shellfish Immunology 3:253-265.

Muir, W. D., S. G. Smith, R. N. Iwamoto, D. J. Kamikawa, K. W. McIntyre, E. E. Hockersmith, B. P. Sandford, P. A. Ocker, T. E. Reuhle, J. G. Williams, and J. R. Skalski. 1995. Survival estimates for the passage of yearling salmonids through Snake River dams and reservoirs, 1994. Annual report (Project No. 93-29) to Bonneville Power Administration, Portland, Oregon, and U.S. Army Corps of Engineers, Walla Walla District, Walla Walla, Washington.

Muona, M., and A. Soivio. 1992. Changes in plasma lysozyme and blood leucocyte levels of hatchery-reared Atlantic salmon (Salmo salar L.) and sea trout (Salmo trutta L.) during parr-smolt transformation. Aquaculture 106:75-87.

Murray, C. K., and T. C. Fletcher. 1976. The immunohistological localization of lysozyme in plaice (Pleuronectes platessa L.) tissues. Journal of Fish Biology 9:329-334.

Pagliarani, A., V. Ventrella, R. Ballestrazzi, F. Trombetti, M. Pirini, and G. Trigari. 1991. Salinity-dependence of the properties of gill $\left(\mathrm{Na}^{+}+\mathrm{K}^{+}\right)$-ATPase in rainbow trout (Oncorhynchus mykiss). Comparative Biochemistry and Physiology 100B(2):229-236. 
Pascho, R. J., D. G. Elliott, and J. M. Streufert. 1991. Brood stock segregation of spring chinook salmon Oncorhynchus tshawytscha by use of the enzyme-linked immunosorbent assay (ELISA) and the fluorescent antibody technique (FAT) affects the prevalence and levels of Renibacterium salmoninarum infection in progeny. Diseases of Aquatic Organisms 12:25-40.

Pickering, A. D., and R. H. Richards. 1980. Factors influencing the structure, function and biota of the salmonid epidermis. Proceedings of the Royal Society of Edinburgh 79B:93-104.

Redding, J. M., C. B. Schreck, E. K. Birks, and R. D. Ewing. 1984. Cortisol and its effects on plasma thyroid hormone and electrolyte concentrations in fresh water and during seawater acclimation in yearling coho salmon, Oncorhynchus kisutch. General and Comparative Endocrinology 56:146-155.

Røed, K. H., E. Brun, H. J. Larsen, and T. Refstie. 1990. The genetic influence on serum haemolytic activity in rainbow trout. Aquaculture 85:109-117.

Røed, K. H., H. J. S. Larsen, R. D. Linder and T. Refstie. 1993. Genetic variation in lysozyme activity in rainbow trout (Oncorhynchus mykiss). Aquaculture 109:237-244.

Rondorf, D. W., J. W. Beeman, M. E. Free, and D. E. Liljegren. 1988. Correlation of biological characteristics of smolts with survival and travel time. Annual report 1987 (Contract DEA179-87BP35245) to Bonneville Power Administration, Portland, Oregon.

Rondorf, D. W., J. W. Beeman, J. C. Faler, M. E. Free, and E. J. Wagner. 1989. Assessment of smolt condition for travel time analysis. Annual report 1988 (Contract DE-A17987BP35245) to Bonneville Power Administration, Portland, Oregon.

Sankaran, K., and S. Gurnani. 1972. On the variation in the catalytic activity of lysozyme in fish. Indian Journal of Biochemistry and Biophysics 9:162-165.

Saunders, R. L. and E. B. Henderson. 1978. Changes in gill ATPase activity and smolt status of Atlantic salmon (Salmo salar). Journal of the Fisheries Research Board of Canada 35:1542-1546.

Schrock, R. M., J. W. Beeman, D. W. Rondorf, and P. V. Haner. 1994. A microassay for gill sodium, potassium-activated ATPase in juvenile Pacific salmon. Transactions of the American Fisheries Society 123:223-229.

Schultz. A. L. 1987. Lysozyme. Pages 742-746 in A. J. Pesce and L. A. Kaplan (eds.), Methods in Clinical Chemistry. The C.V. Mosby Company, St. Louis, Missouri. 
Shrimpton, J. M., N. J. Bernier, G. K. Iwama, and D. J. Randall. 1994. Differences in measurements of smolt development between wild and hatchery-reared juvenile coho salmon (Oncorhynchus kisutch) before and after saltwater exposure. Canadian Journal of Fisheries and Aquatic Sciences 51:2170-2178.

Sower, S. A., and R. S. Fawcett. 1991. Changes in gill $\mathrm{Na}^{+}, \mathrm{K}^{+}$-ATPase, thyroxine and triiodothyronine of coho salmon held in two different rearing densities during smoltification. Comparative Biochemistry and Physiology 99A:85-89.

Specker, J. L. and C. B. Schreck. 1982. Changes in corticosteroids during smoltification of coho salmon, Oncorhynchus kisutch. General and Comparative Endocrinology 46:53-58.

Staley, K. B. and R. D. Ewing. 1992. Purine levels in the skin of juvenile coho salmon (Oncorhynchus kisutch) during parr-smolt transformation and adaptation to seawater. Comparative Biochemistry and Physiology 101B(3):447-452.

Sveinbjørnsson, B., R. Olsen, and S. Paulsen. 1996. Immunocytochemical localization of lysozyme in intestinal eosinophilic granule cells (EGCs) of Atlantic salmon, Salmo salar L. Journal of Fish Diseases 19:349-355.

University of Washington. 1998. Columbia River Data Access in Real Time (DART), River Environment (U. S. Army Corps of Engineers data). Internet address: http://www.cqs.washington.edu/dart/river.html.

Wedemeyer, G. A., R. L. Saunders, and W. C. Clarke. 1980. Environmental factors affecting smoltification and early marine survival of anadromous salmonids. National Marine Fisheries Service Marine Fisheries Review 42:1-14.

Yousif, A. N., L. J. Albright, and T. P. T. Evelyn. 1994. In vitro evidence for the antibacterial role of lysozyme in salmonid eggs. Diseases of Aquatic Organisms 19:15-19.

Zaugg, W. S. 1981. Advanced photoperiod and water temperature effects on gill $\mathrm{Na}^{+}, \mathrm{K}^{+}$ adenosine triphosphatase activity and migration of juvenile steelhead (Salmo gairdneri). Canadian Journal of Fisheries and Aquatic Sciences 38:758-764.

Zaugg, W. S. 1982a. A simplified preparation for adenosine triphosphatase determination in gill tissue. Canadian Journal of Fisheries and Aquatic Sciences 39:215-217.

Zaugg, W. S. 1982b. Some changes in smoltification and seawater adaptability of salmonids resulting from environmental and other factors. Aquaculture 28:143-151. 
Zaugg, W. S., and L. R. McLain. 1970. Adenosine triphosphatase activity in gills of salmonids: seasonal variations and salt water influence in coho salmon, Oncorhynchus kisutch. Comparative Biochemistry and Physiology 35:587-596.

Zaugg, W. S., and L. R. McLain. 1972. Changes in gill adenosine triphosphatase activity associated with parr-smolt transformation in steelhead trout, coho, and spring chinook salmon. Journal of the Fisheries Research Board of Canada 29:167-171.

Zaugg, W. S., and B. R. Beckman. 1990. Saltwater-induced decreases in weight and length relative to seasonal gill $\mathrm{Na}^{+}-\mathrm{K}^{+}$ATPase changes in coho salmon (Oncorhynchus kisutch): a test for seawater adaptability. Aquaculture 86:19-23.

Zaugg, W. S., E. F. Prentice, and F. W. Waknitz. 1985. Importance of river migration to the development of seawater tolerance in Columbia River anadromous salmonids. Aquaculture 51(1):33-47. 
APPENDICES 
Appendix A.1. Summary of selected data from yearling spring/summer chinook salmon sampled at Dworshak NFH (DW), Entiat NFH (EN), Leavenworth NFH (LE), Little White Salmon NFH (LW), McCall SFH (MC), Rapid River SFH (RA), Ringold SFH (RI), Sawtooth SFH (SA), and Winthrop NFH (WI) during spring 1993. Data includes sample size $(\mathrm{N})$, mean (MEAN), and standard error (STDERR) of fork length in millimeters, wet weight in grams, condition factor (KFACTOR), and gill $\mathrm{Na}^{+}, \mathrm{K}^{+}$-ATPase activity (ATPase) in $\mu \mathrm{mol} \mathrm{P}_{\mathrm{i}} \cdot \mathrm{mg}$ protein ${ }^{-1} \cdot \mathrm{h}^{-1}$.

\begin{tabular}{|c|c|c|c|c|c|c|c|c|c|c|c|c|c|}
\hline & & \multirow{2}{*}{\multicolumn{3}{|c|}{ FORK LENGTH }} & \multirow{2}{*}{\multicolumn{3}{|c|}{ WEIGHT }} & \multicolumn{3}{|c|}{ KFACTOR } & \multicolumn{3}{|c|}{ ATPase } \\
\hline & & & & & & & & \multirow[b]{2}{*}{$N$} & \multirow[b]{2}{*}{ MEAN } & \multirow{2}{*}{$\begin{array}{r}\text { STD - } \\
\text { ERR }\end{array}$} & \multirow[b]{2}{*}{$N$} & \multirow[b]{2}{*}{ MEAN } & \multirow{2}{*}{$\begin{array}{r}\text { STD- } \\
\text { ERR }\end{array}$} \\
\hline & & $N$ & MEAN & STDERR & N & MEAN & STDERR & & & & & & \\
\hline SITE & DATE & & & & & & & & & & & & \\
\hline \multirow[t]{3}{*}{ DW } & 22MAR1993 & 120 & 129.0 & 2.12 & 0 & . & . & 0 & & . & 118 & 7.7 & 0.25 \\
\hline & 05APR1993 & 160 & 135.0 & 1.80 & 0 & . & & 0 & & . & 155 & 10.7 & 0.25 \\
\hline & 19APR1993 & 80 & 135.1 & 2.35 & 0 & . & . & 0 & &. & 75 & 10.1 & 0.33 \\
\hline EN & 30MAR1993 & 30 & 137.7 & 2.71 & 30 & 30.5 & 1.77 & 30 & 1.13 & 0.01 & 25 & 14.0 & 1.32 \\
\hline LE & 11APR1993 & 30 & 131.3 & 3.00 & 30 & 26.3 & 1.94 & 30 & 1.11 & 0.01 & 29 & 11.5 & 0.67 \\
\hline LW & 07JUL1993 & 29 & 87.0 & 1.63 & 29 & 8.2 & 0.46 & 29 & 1.22 & 0.02 & 29 & 10.4 & 0.48 \\
\hline MC & 23MAR1993 & 30 & 127.5 & 1.57 & 30 & 24.5 & 0.92 & 30 & 1.16 & 0.01 & 30 & 11.8 & 0.80 \\
\hline RA & 24MAR1993 & 30 & 114.5 & 1.39 & 30 & 16.4 & 0.63 & 30 & 1.08 & 0.01 & 30 & 11.0 & 0.86 \\
\hline $\mathrm{RI}$ & 31 MAR1993 & 29 & 228.8 & 5.08 & 29 & 157.1 & 10.88 & 29 & 1.25 & 0.02 & 29 & 15.2 & 1.35 \\
\hline SA & 22MAR1993 & 30 & 115.7 & 1.51 & 30 & 17.4 & 0.67 & 30 & 1.10 & 0.01 & 30 & 11.0 & 0.67 \\
\hline WI & 10APR1993 & 30 & 137.2 & 2.83 & 30 & 29.8 & 1.88 & 30 & 1.11 & 0.02 & 29 & 11.6 & 0.57 \\
\hline
\end{tabular}

Appendix A.2. Summary of selected data from subyearling chinook salmon sampled at Priest Rapids SFH (PR) and Turtle Rock SFH (TR). Data includes sample size (N), mean (MEAN), and standard error (STDERR) of fork length in millimeters, wet weight in grams, condition factor (KFACTOR), and gill $\mathrm{Na}^{+}, \mathrm{K}^{+}$-ATPase activity (ATPase) in $\mu \mathrm{mol} \mathrm{P}_{\mathrm{i}}$. mg protein ${ }^{-1} \cdot \mathrm{h}^{-1}$.

\begin{tabular}{|c|c|c|c|c|c|c|c|c|c|c|c|c|c|}
\hline & & \multirow{2}{*}{\multicolumn{3}{|c|}{ FORK LENGTH }} & \multirow{2}{*}{\multicolumn{3}{|c|}{ WEIGHT }} & \multicolumn{3}{|c|}{ KFACTOR } & \multicolumn{3}{|c|}{ ATPase } \\
\hline & & & & & & & & \multirow[b]{2}{*}{$\mathrm{N}$} & \multirow[b]{2}{*}{ MEAN } & \multirow{2}{*}{$\begin{array}{l}\text { STD- } \\
\text { ERR }\end{array}$} & \multirow[b]{2}{*}{ N } & \multirow[b]{2}{*}{ MEAN } & \multirow{2}{*}{$\begin{array}{l}\text { STD- } \\
\text { ERR }\end{array}$} \\
\hline & & N & MEAN & STDERR & $\mathrm{N}$ & MEAN & STDERR & & & & & & \\
\hline SITE & DATE & & & & & & & & & & & & \\
\hline \multirow[t]{2}{*}{ PR } & 14JUN1993 & 90 & 90.8 & 0.85 & 90 & 8.1 & 0.23 & 90 & 1.05 & 0.01 & 90 & 13.4 & 0.45 \\
\hline & 21JUN1993 & 60 & 93.2 & 0.86 & 60 & 8.6 & 0.24 & 60 & 1.05 & 0.01 & 60 & 12.4 & 0.57 \\
\hline TR & 24JUN1993 & 30 & 92.8 & 1.36 & 30 & 9.2 & 0.42 & 30 & 1.13 & 0.02 & 30 & 17.0 & 0.72 \\
\hline
\end{tabular}

Appendix A.3. Summary of selected data from steelhead sampled at Dworshak NFH (DW) and Irrigon SFH (IR) during spring 1993. Data includes sample size (N), mean (MEAN), and standard error (STDERR) of fork length in millimeters, wet weight in grams, condition factor (KFACTOR), and gill $\mathrm{Na}^{+}, \mathrm{K}^{+}$-ATPase activity (ATPase) in $\mu \mathrm{mol} \mathrm{P}_{\mathrm{i}} \cdot \mathrm{mg} \operatorname{protein}^{-1} \cdot \mathrm{h}^{-1}$.

\begin{tabular}{|c|c|c|c|c|c|c|c|c|c|c|c|c|c|}
\hline & & \multirow{2}{*}{\multicolumn{3}{|c|}{ FORK LENGTH }} & \multirow{2}{*}{\multicolumn{3}{|c|}{ WEIGHT }} & \multicolumn{3}{|c|}{ KFACTOR } & \multicolumn{3}{|c|}{ ATPase } \\
\hline & & & & & & & & \multirow[b]{2}{*}{ N } & \multirow[b]{2}{*}{ MEAN } & \multirow{2}{*}{$\begin{array}{r}\text { STD- } \\
\text { ERR }\end{array}$} & \multirow[b]{2}{*}{ N } & \multirow[b]{2}{*}{ MEAN } & \multirow{2}{*}{$\begin{array}{l}\text { STD - } \\
\text { ERR }\end{array}$} \\
\hline & & N & MEAN & STDERR & $\mathrm{N}$ & MEAN & STDERR & & & & & & \\
\hline SITE & DATE & & & & & & & & & & & & \\
\hline $\mathrm{DW}$ & 29APR1993 & 30 & 187.5 & 5.20 & 30 & 65.9 & 4.77 & 30 & 0.95 & 0.01 & 30 & 10.9 & 0.73 \\
\hline IR & $02 A P R 1993$ & 30 & 203.8 & 2.82 & 30 & 92.3 & 3.45 & 30 & 1.08 & 0.02 & 30 & 13.3 & 0.81 \\
\hline
\end{tabular}


Appendix B.1. Summary of selected data from yearling hatchery spring/summer chinook salmon collected from the migration-at-large at the Clearwater River Trap (CLW), Snake River Trap at Lewiston (LEW),

Salmon River Trap (SRT), Lower Granite Dam (LGR), Little Goose Dam (LGS), McNary Dam (MCN), and Rock Island Dam (RIS) during spring 1993. Data includes sample size (N), mean (MEAN), and standard error (STDERR) of fork length in millimeters, condition factor (KFACTOR), wet weight in grams, and gill $\mathrm{Na}^{+}, \mathrm{K}^{+}$-ATPase activity (ATPase) in $\mu \mathrm{mol} \mathrm{P}_{\mathrm{i}} \cdot \mathrm{mg}_{\text {protein }}{ }^{-1} \cdot \mathrm{h}^{-1}$.

\begin{tabular}{|c|c|c|c|c|c|c|c|c|c|c|c|c|c|}
\hline & & \multirow{2}{*}{\multicolumn{3}{|c|}{ FORK LENGTH }} & \multirow{2}{*}{\multicolumn{3}{|c|}{ WEIGHT }} & \multicolumn{3}{|c|}{ KFACTOR } & \multicolumn{3}{|c|}{ ATPase } \\
\hline & & & & & & & & \multirow[b]{2}{*}{ N } & \multirow[b]{2}{*}{ MEAN } & \multirow{2}{*}{$\begin{array}{l}\text { STD - } \\
\text { ERR }\end{array}$} & \multirow[b]{2}{*}{$\mathbf{N}$} & \multirow[b]{2}{*}{ MEAN } & \multirow{2}{*}{$\begin{array}{r}\text { STD- } \\
\text { ERR }\end{array}$} \\
\hline & & N & MEAN & STDERR & N & MEAN & STDERR & & & & & & \\
\hline SITE & DATE & & & & & & & & & & & & \\
\hline \multirow[t]{10}{*}{ CLW } & 12APR1993 & 20 & 122.0 & 2.06 & 20 & 19.7 & 1.08 & 20 & 1.07 & 0.01 & 18 & 9.5 & 0.83 \\
\hline & 14APR1993 & 20 & 114.8 & 1.98 & 20 & 16.4 & 0.82 & 20 & 1.07 & 0.01 & 18 & 8.4 & 0.80 \\
\hline & 16APR1993 & 18 & 145.2 & 5.44 & 18 & 36.6 & 4.57 & 18 & 1.10 & 0.03 & 20 & 12.3 & 0.91 \\
\hline & 19APR1993 & 1 & 124.0 & & 1 & 19.8 & & 1 & 1.04 & & 1 & 9.0 & \\
\hline & 21APR1993 & 20 & 134.8 & 4.04 & 20 & 27.9 & 2.44 & 20 & 1.09 & 0.01 & 20 & 13.1 & 0.80 \\
\hline & 23APR1993 & 19 & 145.4 & 6.13 & 19 & 34.6 & 4.37 & 19 & 1.03 & 0.01 & 19 & 11.6 & 1.00 \\
\hline & 26APR1993 & 18 & 127.6 & 3.78 & 0 & & & 0 & & & 18 & 14.2 & 0.81 \\
\hline & 28APR1993 & 24 & 123.0 & 3.30 & 24 & 20.1 & 1.73 & 24 & 1.03 & 0.02 & 23 & 11.5 & 1.00 \\
\hline & 30APR1993 & 19 & 132.4 & 4.78 & 19 & 26.7 & 2.80 & 19 & 1.09 & 0.02 & 20 & 13.0 & 1.17 \\
\hline & 03 MAY1993 & 21 & 122.9 & 2.79 & 21 & 21.6 & 1.68 & 21 & 1.13 & 0.01 & 21 & 17.9 & 1.35 \\
\hline \multirow[t]{17}{*}{ LEW } & 12APR1993 & 20 & 127.6 & 2.10 & 20 & 23.0 & 1.31 & 20 & 1.09 & 0.02 & 20 & 10.9 & 0.91 \\
\hline & 14APR1993 & 18 & 129.1 & 3.31 & 18 & 23.1 & 2.21 & 18 & 1.04 & 0.01 & 18 & 13.1 & 1.17 \\
\hline & 16APR1993 & 15 & 126.9 & 2.78 & 15 & 22.2 & 1.59 & 15 & 1.07 & 0.01 & 15 & 16.3 & 1.57 \\
\hline & 19APR1993 & 21 & 121.1 & 2.45 & 21 & 18.6 & 1.06 & 21 & 1.03 & 0.01 & 21 & 11.0 & 0.97 \\
\hline & 21APR1993 & 20 & 120.4 & 1.87 & 19 & 22.0 & 3.45 & 19 & 1.28 & 0.24 & 19 & 13.5 & 1.18 \\
\hline & 23APR1993 & 25 & 123.3 & 1.55 & 25 & 22.1 & 0.88 & 25 & 1.17 & 0.03 & 25 & 14.9 & 1.18 \\
\hline & 26APR1993 & 19 & 122.5 & 1.51 & 19 & 18.9 & 1.00 & 19 & 1.01 & 0.02 & 17 & 13.2 & 1.23 \\
\hline & 28APR1993 & 26 & 122.3 & 2.22 & 26 & 19.4 & 1.02 & 26 & 1.04 & 0.01 & 26 & 14.2 & 0.73 \\
\hline & 30APR1993 & 20 & 126.6 & 2.00 & 19 & 21.7 & 1.27 & 19 & 1.05 & 0.01 & 20 & 12.5 & 1.47 \\
\hline & 03MAY1993 & 20 & 125.4 & 2.10 & 20 & 22.3 & 1.06 & 20 & 1.12 & 0.02 & 20 & 21.5 & 1.20 \\
\hline & 05 MAY1993 & 21 & 125.2 & 2.14 & 20 & 20.0 & 1.22 & 20 & 1.01 & 0.01 & 21 & 18.6 & 1.41 \\
\hline & 07 MAY1993 & 20 & 120.8 & 2.07 & 20 & 16.9 & 0.98 & 20 & 0.94 & 0.02 & 20 & 22.2 & 1.87 \\
\hline & 10MAY1993 & 20 & 133.5 & 2.34 & 20 & 22.6 & 1.31 & 20 & 0.93 & 0.02 & 20 & 19.2 & 1.20 \\
\hline & 12 MAY1993 & 21 & 130.9 & 2.31 & 20 & 23.4 & 1.12 & 20 & 1.04 & 0.03 & 21 & 23.0 & 1.68 \\
\hline & $14 M A Y 1993$ & 20 & 135.4 & 3.31 & 20 & 25.1 & 1.61 & 20 & 0.99 & 0.01 & 20 & 20.7 & 1.39 \\
\hline & 31 MAY1993 & 12 & 125.6 & 4.79 & 12 & 21.0 & 2.28 & 12 & 1.02 & 0.01 & 11 & 19.4 & 1.35 \\
\hline & 02JUN1993 & 22 & 135.2 & 2.95 & 22 & 24.4 & 1.54 & 22 & 0.96 & 0.01 & 22 & 22.8 & 0.86 \\
\hline \multirow[t]{9}{*}{ SRT } & 13APR1993 & 40 & 126.1 & 1.77 & 40 & 22.2 & 0.83 & 40 & 1.09 & 0.01 & 39 & 13.0 & 0.56 \\
\hline & 15APR1993 & 42 & 129.4 & 2.36 & 42 & 23.7 & 1.60 & 42 & 1.06 & 0.01 & 41 & 13.6 & 0.78 \\
\hline & 20APR1993 & 42 & 127.0 & 2.94 & 42 & 20.0 & 2.32 & 42 & 0.91 & 0.01 & 42 & 9.2 & 0.40 \\
\hline & 22APR 1993 & 40 & 124.0 & 1.49 & 40 & 18.5 & 1.01 & 40 & 0.94 & 0.02 & 40 & 9.1 & 0.46 \\
\hline & 27APR1993 & 48 & 124.0 & 1.89 & 48 & 18.5 & 0.94 & 48 & 0.94 & 0.01 & 48 & 11.5 & 0.74 \\
\hline & 29APR1993 & 42 & 130.9 & 2.78 & 42 & 23.3 & 1.71 & 42 & 0.98 & 0.01 & 42 & 14.7 & 0.89 \\
\hline & 04 MAY1993 & 40 & 131.5 & 1.39 & 40 & 23.1 & 0.78 & 40 & 1.01 & 0.01 & 40 & 15.5 & 0.96 \\
\hline & 06MAY1993 & 41 & 131.9 & 1.77 & 41 & 23.4 & 0.92 & 41 & 1.00 & 0.01 & 41 & 17.4 & 0.81 \\
\hline & 11 MAY1993 & 40 & 132.4 & 1.92 & 40 & 23.0 & 1.00 & 40 & 0.97 & 0.01 & 40 & 16.8 & 0.95 \\
\hline \multirow[t]{12}{*}{ LGR } & 27APR1993 & 29 & 135.1 & 3.37 & 30 & 25.5 & 2.61 & 29 & 0.97 & 0.01 & 30 & 20.6 & 1.00 \\
\hline & 29APR1993 & 30 & 140.3 & 2.82 & 30 & 26.0 & 1.81 & 30 & 0.91 & 0.01 & 30 & 22.3 & 1.10 \\
\hline & 04 MAY1993 & 20 & 135.4 & 2.04 & 20 & 23.8 & 1.33 & 20 & 0.94 & 0.01 & 20 & 23.8 & 1.72 \\
\hline & 06MAY1993 & 20 & 126.0 & 2.12 & 20 & 19.4 & 1.03 & 20 & 0.95 & 0.01 & 20 & 23.3 & 1.34 \\
\hline & 11MAY1993 & 30 & 138.4 & 3.19 & 30 & 26.5 & 2.36 & 30 & 0.94 & 0.01 & 29 & 23.1 & 1.32 \\
\hline & 13 MAY1993 & 20 & 132.5 & 2.51 & 20 & 23.1 & 1.51 & 20 & 0.97 & 0.01 & 20 & 23.3 & 1.51 \\
\hline & 18MAY1993 & 20 & 137.1 & 3.12 & 20 & 25.7 & 1.79 & 20 & 0.97 & 0.02 & 20 & 24.5 & 0.94 \\
\hline & 20 MAY1993 & 20 & 142.7 & 2.84 & 20 & 29.1 & 1.80 & 20 & 0.98 & 0.01 & 20 & 24.8 & 1.09 \\
\hline & 25MAY1993 & 20 & 141.7 & 2.48 & 20 & 27.8 & 1.57 & 20 & 0.96 & 0.01 & 20 & 25.1 & 0.80 \\
\hline & 27 MAY1993 & 20 & 136.1 & 2.47 & 20 & 24.5 & 1.32 & 20 & 0.95 & 0.01 & 20 & 21.6 & 0.96 \\
\hline & 01JUN1993 & 20 & 142.1 & 2.49 & 20 & 28.6 & 1.46 & 20 & 0.98 & 0.01 & 20 & 25.5 & 1.20 \\
\hline & 03JUN1993 & 21 & 142.7 & 1.70 & 21 & 28.0 & 0.98 & 21 & 0.96 & 0.02 & 20 & 25.2 & 0.85 \\
\hline
\end{tabular}


Appendix B.1 (continued)

\begin{tabular}{|c|c|c|c|c|c|c|c|c|c|c|c|c|c|}
\hline & & \multirow{2}{*}{\multicolumn{3}{|c|}{ FORK LENGTH }} & \multirow{2}{*}{\multicolumn{3}{|c|}{ WEIGHT }} & \multicolumn{3}{|c|}{ KFACTOR } & \multicolumn{3}{|c|}{ ATPase } \\
\hline & & & & & & & & \multirow[b]{2}{*}{$N$} & \multirow[b]{2}{*}{ MEAN } & \multirow{2}{*}{$\begin{array}{r}\text { STD - } \\
\text { ERR }\end{array}$} & \multirow[b]{2}{*}{$N$} & \multirow[b]{2}{*}{ MEAN } & \multirow{2}{*}{$\begin{array}{r}\text { STD- } \\
\text { ERR }\end{array}$} \\
\hline & & N & MEAN & STDERR & N & MEAN & STDERR & & & & & & \\
\hline SITE & DATE & & & & & & & & & & & & \\
\hline \multirow[t]{16}{*}{ LGS } & 26APR1993 & 18 & 148.9 & 5.55 & 16 & 34.9 & 6.62 & 16 & 0.96 & 0.02 & 17 & 24.2 & 1.57 \\
\hline & 28APR1993 & 22 & 138.7 & 2.58 & 22 & 25.7 & 1.87 & 22 & 0.93 & 0.01 & 22 & 27.0 & 1.90 \\
\hline & 30APR1993 & 20 & 139.7 & 2.58 & 20 & 26.1 & 1.67 & 20 & 0.93 & 0.01 & 20 & 27.9 & 1.58 \\
\hline & 03MAY1993 & 20 & 139.4 & 4.22 & 20 & 25.4 & 3.24 & 20 & 0.88 & 0.01 & 20 & 27.7 & 1.18 \\
\hline & 05MAY1993 & 30 & 132.3 & 1.58 & 30 & 20.9 & 0.91 & 30 & 0.89 & 0.01 & 30 & 25.9 & 1.02 \\
\hline & 06MAY1993 & 30 & 128.6 & 1.92 & 29 & 22.6 & 1.15 & 29 & 1.04 & 0.02 & 30 & 29.3 & 1.51 \\
\hline & 07 MAY1993 & 30 & 125.8 & 1.24 & 30 & 21.2 & 0.70 & 30 & 1.06 & 0.01 & 30 & 26.2 & 1.15 \\
\hline & 10MAY1993 & 20 & 130.7 & 2.09 & 20 & 19.2 & 0.90 & 20 & 0.85 & 0.01 & 20 & 24.0 & 1.62 \\
\hline & 12MAY1993 & 21 & 129.8 & 2.58 & 30 & 24.3 & 1.00 & 21 & 1.11 & 0.02 & 30 & 27.2 & 1.06 \\
\hline & 13MAY1993 & 30 & 132.6 & 1.48 & 30 & 22.8 & 0.84 & 30 & 0.97 & 0.01 & 30 & 30.3 & 1.12 \\
\hline & 17MAY1993 & 20 & 143.2 & 2.90 & 20 & 27.4 & 1.94 & 20 & 0.91 & 0.02 & 20 & 28.1 & 1.50 \\
\hline & 19MAY1993 & 20 & 137.8 & 2.10 & 20 & 23.4 & 1.16 & 20 & 0.88 & 0.01 & 20 & 25.7 & 0.88 \\
\hline & 21 MAY1993 & 20 & 145.2 & 2.74 & 20 & 29.4 & 2.03 & 20 & 0.93 & 0.02 & 20 & 27.1 & 1.55 \\
\hline & 24MAY1993 & 20 & 145.9 & 2.81 & 20 & 28.4 & 1.90 & 20 & 0.88 & 0.02 & 20 & 25.9 & 1.08 \\
\hline & 26MAY1993 & 20 & 145.2 & 2.08 & 20 & 28.0 & 1.43 & 20 & 0.90 & 0.01 & 20 & 24.7 & 1.36 \\
\hline & 28MAY1993 & 20 & 147.3 & 2.00 & 20 & 29.1 & 1.29 & 20 & 0.90 & 0.01 & 20 & 28.7 & 0.98 \\
\hline \multirow[t]{2}{*}{ MCN } & 12 MAY1993 & 9 & 142.4 & 3.93 & 9 & 27.0 & 2.18 & 9 & 0.92 & 0.03 & 9 & 25.9 & 2.11 \\
\hline & 26MAY1993 & 9 & 157.1 & 6.71 & 9 & 38.5 & 5.62 & 9 & 0.94 & 0.02 & 9 & 19.9 & 1.92 \\
\hline \multirow[t]{22}{*}{ RIS } & 26APR1993 & 5 & 132.8 & 8.13 & 5 & 26.3 & 4.87 & 5 & 1.08 & 0.03 & 5 & 9.5 & 1.13 \\
\hline & 27APR1993 & 3 & 129.0 & 3.51 & 3 & 23.8 & 1.31 & 3 & 1.11 & 0.03 & 3 & 11.5 & 1.48 \\
\hline & 28APR1993 & 7 & 145.3 & 9.09 & 7 & 36.0 & 6.39 & 7 & 1.08 & 0.03 & 7 & 11.8 & 1.80 \\
\hline & 29APR1993 & 5 & 132.8 & 9.93 & 5 & 25.8 & 5.24 & 5 & 1.06 & 0.08 & 5 & 13.9 & 1.68 \\
\hline & 03MAY1993 & 5 & 146.0 & 5.21 & 5 & 30.2 & 2.78 & 5 & 0.96 & 0.03 & 5 & 12.0 & 1.06 \\
\hline & 04 MAY1993 & 11 & 143.6 & 5.33 & 11 & 29.1 & 2.98 & 11 & 0.95 & 0.02 & 11 & 15.9 & 1.54 \\
\hline & 05 MAY1993 & 5 & 135.2 & 12.69 & 5 & 25.8 & 6.17 & 5 & 0.96 & 0.03 & 5 & 12.5 & 3.37 \\
\hline & 06MAY1993 & 6 & 148.0 & 4.91 & 6 & 32.0 & 2.86 & 6 & 0.97 & 0.02 & 6 & 11.0 & 1.76 \\
\hline & 10MAY1993 & 7 & 167.4 & 7.85 & 7 & 44.1 & 5.94 & 7 & 0.90 & 0.02 & 7 & 25.4 & 3.25 \\
\hline & 11 MAY1993 & 8 & 142.0 & 6.91 & 8 & 29.4 & 3.93 & 8 & 0.99 & 0.02 & 8 & 22.4 & 4.18 \\
\hline & 12 MAY1993 & 13 & 155.8 & 5.85 & 13 & 41.0 & 4.53 & 13 & 1.04 & 0.03 & 13 & 14.9 & 1.94 \\
\hline & 13MAY1993 & 13 & 153.7 & 8.50 & 13 & 42.7 & 7.35 & 13 & 1.06 & 0.02 & 13 & 23.6 & 3.09 \\
\hline & 17IMAY1993 & 12 & 145.2 & 4.81 & 12 & 32.1 & 2.91 & 12 & 1.02 & 0.02 & 12 & 24.4 & 2.69 \\
\hline & 18 MAY1993 & 10 & 141.3 & 5.24 & 10 & 30.9 & 3.64 & 10 & 1.06 & 0.02 & 10 & 29.1 & 1.39 \\
\hline & 19MAY1993 & 11 & 154.1 & 8.04 & 11 & 40.5 & 5.72 & 11 & 1.04 & 0.02 & 11 & 26.8 & 2.90 \\
\hline & 20MAY1993 & 10 & 146.7 & 7.15 & 10 & 33.7 & 4.95 & 10 & 1.02 & 0.02 & 10 & 26.0 & 2.64 \\
\hline & 24MAY1993 & 9 & 140.0 & 6.53 & 9 & 24.8 & 3.81 & 9 & 0.86 & 0.02 & 9 & 23.2 & 3.42 \\
\hline & 25MAY1993 & 9 & 155.2 & 8.56 & 9 & 38.6 & 7.23 & 9 & 0.96 & 0.03 & 9 & 21.6 & 1.52 \\
\hline & 26MAY1993 & 12 & 137.2 & 5.97 & 12 & 25.6 & 3.32 & 12 & 0.95 & 0.03 & 12 & 24.0 & 2.39 \\
\hline & 27IMAY1993 & 10 & 146.4 & 4.87 & 10 & 32.5 & 2.90 & 10 & 1.02 & 0.03 & 10 & 20.7 & 1.48 \\
\hline & 28MAY1993 & 8 & 158.4 & 9.58 & 8 & 45.5 & 8.73 & 8 & 1.06 & 0.03 & 8 & 22.5 & 2.42 \\
\hline & 29MAY1993 & 19 & 153.2 & 3.93 & 19 & 36.8 & 3.25 & 19 & 0.98 & 0.01 & 18 & 20.4 & 1.47 \\
\hline
\end{tabular}


Appendix B.2. Summary of selected data from non-adipose fin-clipped yearling spring/summer chinook salmon collected from the migration-at-large at McNary Dam (MCN) and Rock Island Dam (RIS) during spring 1993. Data includes sample size (N), mean (MEAN), and standard error (STDERR) of fork length in millimeters, wet weight in grams, condition factor (KFACTOR), and gill $\mathrm{Na}^{+}, \mathrm{K}^{+}$-ATPase activity (ATPase) in $\mu$ mol $\mathrm{P}_{\mathrm{i}} \cdot \mathrm{mg}_{\mathrm{g}}$ protein $^{-1} \cdot \mathrm{h}^{-1}$.

\begin{tabular}{|c|c|c|c|c|c|c|c|c|c|c|c|c|c|}
\hline & & \multirow{2}{*}{\multicolumn{3}{|c|}{ FORK LENGTH }} & \multirow{2}{*}{\multicolumn{3}{|c|}{ WEIGHT }} & \multicolumn{3}{|c|}{ KFACTOR } & \multicolumn{3}{|c|}{ ATPase } \\
\hline & & & & & & & & \multirow[b]{2}{*}{$N$} & \multirow[b]{2}{*}{ MEAN } & \multirow{2}{*}{$\begin{array}{r}\text { STD - } \\
\text { ERR }\end{array}$} & \multirow[b]{2}{*}{$N$} & \multirow[b]{2}{*}{ MEAN } & \multirow{2}{*}{$\begin{array}{r}\text { STD - } \\
\text { ERR }\end{array}$} \\
\hline & & $N$ & MEAN & STDERR & $N$ & MEAN & STDERR & & & & & & \\
\hline SITE & DATE & & & & & & & & & & & & \\
\hline \multirow[t]{6}{*}{ MCN } & 21APR1993 & 20 & 203.3 & 8.65 & 20 & 95.6 & 12.16 & 20 & 1.02 & 0.02 & 20 & 17.9 & 1.44 \\
\hline & 28APR1993 & 20 & 196.2 & 6.99 & 18 & 74.9 & 8.02 & 18 & 0.97 & 0.02 & 20 & 20.6 & 1.74 \\
\hline & 04 MAY1993 & 19 & 165.6 & 7.17 & 19 & 47.8 & 7.26 & 19 & 0.94 & 0.02 & 19 & 23.2 & 1.63 \\
\hline & 12 MAY1993 & 11 & 141.9 & 4.62 & 11 & 27.9 & 2.93 & 11 & 0.95 & 0.02 & 11 & 25.2 & 2.28 \\
\hline & 19MAY1993 & 20 & 139.9 & 2.44 & 20 & 25.0 & 1.45 & 20 & 0.90 & 0.01 & 18 & 27.5 & 1.48 \\
\hline & 26 MAY 1993 & 11 & 137.5 & 4.54 & 11 & 25.4 & 2.65 & 11 & 0.95 & 0.02 & 10 & 24.1 & 2.02 \\
\hline \multirow[t]{22}{*}{ RIS } & 26APR1993 & 20 & 137.8 & 3.45 & 20 & 29.2 & 1.91 & 20 & 1.09 & 0.02 & 20 & 9.0 & 0.64 \\
\hline & 27APR1993 & 22 & 132.3 & 2.21 & 22 & 26.2 & 1.42 & 22 & 1.11 & 0.02 & 22 & 10.4 & 0.63 \\
\hline & 28APR1993 & 18 & 130.3 & 3.97 & 18 & 24.7 & 2.16 & 18 & 1.08 & 0.02 & 18 & 13.9 & 0.98 \\
\hline & 29APR1993 & 20 & 129.0 & 2.45 & 20 & 23.8 & 1.25 & 20 & 1.09 & 0.02 & 20 & 13.5 & 0.73 \\
\hline & 03 MAY1993 & 17 & 137.5 & 3.46 & 17 & 26.4 & 1.85 & 17 & 1.00 & 0.02 & 17 & 17.5 & 1.23 \\
\hline & 04MAY1993 & 14 & 137.0 & 5.09 & 14 & 26.5 & 2.93 & 14 & 0.98 & 0.02 & 14 & 13.9 & 1.06 \\
\hline & 05 MAY1993 & 20 & 135.1 & 2.77 & 20 & 24.7 & 1.51 & 20 & 0.98 & 0.01 & 20 & 11.7 & 0.75 \\
\hline & 06MAY1993 & 19 & 139.3 & 3.64 & 19 & 27.6 & 2.06 & 19 & 0.99 & 0.01 & 19 & 12.2 & 0.62 \\
\hline & 10MAY1993 & 18 & 153.4 & 4.09 & 18 & 32.2 & 2.37 & 18 & 0.87 & 0.01 & 18 & 20.3 & 1.08 \\
\hline & 11 MAY1993 & 17 & 142.3 & 3.31 & 17 & 29.1 & 1.86 & 17 & 0.99 & 0.02 & 17 & 17.5 & 1.28 \\
\hline & 12 MAY1993 & 12 & 131.9 & 4.16 & 12 & 26.1 & 2.21 & 12 & 1.11 & 0.02 & 12 & 19.1 & 2.03 \\
\hline & 13 MAY1993 & 12 & 130.8 & 2.23 & 12 & 22.7 & 1.00 & 12 & 1.01 & 0.02 & 12 & 18.3 & 0.57 \\
\hline & 17MAY1993 & 15 & 142.4 & 4.28 & 15 & 30.4 & 2.89 & 15 & 1.02 & 0.02 & 15 & 23.4 & 1.59 \\
\hline & $18 M A Y 1993$ & 15 & 141.3 & 5.87 & 15 & 31.5 & 4.29 & 15 & 1.04 & 0.02 & 15 & 29.0 & 1.97 \\
\hline & 19MAY1993 & 13 & 140.2 & 5.97 & 13 & 31.3 & 3.90 & 13 & 1.09 & 0.03 & 14 & 30.1 & 2.51 \\
\hline & 20MAY1993 & 15 & 144.3 & 5.51 & 15 & 33.2 & 4.47 & 15 & 1.04 & 0.01 & 15 & 26.3 & 1.96 \\
\hline & 24MAY1993 & 16 & 144.4 & 4.89 & 16 & 28.5 & 3.06 & 16 & 0.89 & 0.01 & 13 & 19.7 & 1.37 \\
\hline & 25MAY1993 & 16 & 150.1 & 5.27 & 16 & 34.1 & 3.46 & 16 & 0.96 & 0.01 & 16 & 27.0 & 2.95 \\
\hline & 26MAY1993 & 13 & 136.2 & 5.20 & 13 & 24.4 & 2.54 & 13 & 0.93 & 0.02 & 13 & 28.5 & 1.62 \\
\hline & 27MAY1993 & 16 & 137.3 & 5.62 & 16 & 28.2 & 3.09 & 16 & 1.04 & 0.03 & 16 & 27.5 & 1.96 \\
\hline & 28MAY1993 & 17 & 143.9 & 5.18 & 17 & 33.2 & 3.42 & 17 & 1.06 & 0.02 & 17 & 22.4 & 1.46 \\
\hline & 29MAY1993 & 6 & 168.2 & 6.18 & 6 & 49.2 & 5.12 & 6 & 1.02 & 0.02 & 5 & 17.3 & 4.06 \\
\hline
\end{tabular}


Appendix C. Summary of selected data from yearling wild spring/summer chinook salmon collected from the migration-at-large at the Clearwater River Trap (CLW), Snake River Trap at Lewiston (LEW), Salmon River Trap (SRT), and Lower Granite Dam (LGR) during spring 1993. Data includes sample size (N), mean (MEAN), and standard error (STDERR) of fork length in millimeters, wet weight in grams, condition factor (KFACTOR), and gill $\mathrm{Na}^{+}, \mathrm{K}^{+}$-ATPase activity (ATPASE) in $\mu \mathrm{mol} \mathrm{P}_{\mathrm{i}} \cdot \mathrm{mg} \operatorname{protein}^{-1} \cdot \mathrm{h}^{-1}$.

\begin{tabular}{|c|c|c|c|c|c|c|c|c|c|c|c|c|c|}
\hline & & \multirow{2}{*}{\multicolumn{3}{|c|}{ FORK LENGTH }} & \multirow{2}{*}{\multicolumn{3}{|c|}{ WEIGHT }} & \multicolumn{3}{|c|}{ KFACTOR } & \multicolumn{3}{|c|}{ ATPase } \\
\hline & & & & & & & & \multirow[b]{2}{*}{ N } & \multirow{2}{*}{ MEAN } & \multirow{2}{*}{$\begin{array}{l}\text { STD- } \\
\text { ERR }\end{array}$} & \multirow[b]{2}{*}{$\mathrm{N}$} & \multirow[b]{2}{*}{ MEAN } & \multirow{2}{*}{$\begin{array}{r}\text { STD- } \\
\text { ERR }\end{array}$} \\
\hline & & N & MEAN & STDERR & N & MEAN & STDERR & & & & & & \\
\hline SITE & DATE & & & & & & & & & & & & \\
\hline \multirow[t]{10}{*}{ CLW } & 12APR1993 & 11 & 111.2 & 2.16 & 10 & 15.4 & 1.06 & 10 & 1.13 & 0.04 & 11 & 13.8 & 1.46 \\
\hline & 14APR1993 & 2 & 103.0 & 1.00 & 2 & 13.1 & 0.05 & 2 & 1.20 & 0.03 & 2 & 15.4 & 5.34 \\
\hline & 16APR1993 & 4 & 114.5 & 1.89 & 4 & 16.4 & 0.74 & 4 & 1.09 & 0.07 & 4 & 16.0 & 1.05 \\
\hline & 19APR1993 & 8 & 103.1 & 3.95 & 8 & 12.3 & 1.48 & 8 & 1.08 & 0.02 & 6 & 13.6 & 1.47 \\
\hline & 21APR1993 & 2 & 109.0 & 5.00 & 2 & 15.8 & 3.25 & 2 & 1.20 & 0.09 & 2 & 18.2 & 0.37 \\
\hline & 23APR1993 & 7 & 112.6 & 3.01 & 7 & 17.6 & 1.50 & 7 & 1.22 & 0.03 & 7 & 15.4 & 1.72 \\
\hline & 26APR1993 & 20 & 113.0 & 2.52 & 0 & & & 0 & & & 20 & 16.9 & 1.17 \\
\hline & 28APR1993 & 8 & 113.6 & 3.56 & 8 & 15.8 & 1.19 & 8 & 1.07 & 0.02 & 8 & 16.6 & 1.87 \\
\hline & 30APR1993 & 12 & 108.4 & 2.07 & 12 & 15.4 & 0.78 & 12 & 1.20 & 0.03 & 12 & 16.1 & 1.44 \\
\hline & 03MAY1993 & 6 & 104.7 & 2.58 & 6 & 14.8 & 0.95 & 6 & 1.28 & 0.02 & 6 & 22.9 & 1.81 \\
\hline \multirow[t]{18}{*}{ LEW } & 12APR1993 & 20 & 117.7 & 2.27 & 20 & 18.0 & 1.15 & 20 & 1.08 & 0.01 & 20 & 18.9 & 1.03 \\
\hline & 14APR1993 & 8 & 108.4 & 3.16 & 8 & 13.8 & 1.26 & 8 & 1.06 & 0.02 & 8 & 13.7 & 2.45 \\
\hline & 16APR1993 & 4 & 106.0 & 4.60 & 4 & 13.2 & 1.57 & 4 & 1.09 & 0.03 & 4 & 22.6 & 2.87 \\
\hline & 19APR1993 & 5 & 108.2 & 4.09 & 5 & 14.5 & 1.69 & 5 & 1.13 & 0.03 & 4 & 23.7 & 2.02 \\
\hline & 21APR1993 & 11 & 119.4 & 5.30 & 11 & 18.4 & 2.59 & 11 & 1.05 & 0.04 & 10 & 17.8 & 2.21 \\
\hline & 23APR1993 & 7 & 105.7 & 3.61 & 7 & 14.1 & 1.51 & 7 & 1.19 & 0.09 & 7 & 25.0 & 1.50 \\
\hline & 26APR1993 & 8 & 101.1 & 1.53 & 8 & 11.2 & 0.37 & 8 & 1.08 & 0.02 & 8 & 20.8 & 1.56 \\
\hline & 28APR1993 & 11 & 104.6 & 2.65 & 11 & 12.9 & 1.07 & 11 & 1.10 & 0.02 & 12 & 25.4 & 2.38 \\
\hline & 30APR1993 & 19 & 108.4 & 3.22 & 19 & 14.6 & 1.56 & 19 & 1.08 & 0.04 & 19 & 21.6 & 1.17 \\
\hline & 03MAY1993 & 14 & 102.6 & 1.97 & 14 & 12.3 & 0.60 & 14 & 1.14 & 0.06 & 14 & 27.3 & 2.34 \\
\hline & 05MAY1993 & 25 & 108.7 & 1.37 & 25 & 14.4 & 0.52 & 25 & 1.11 & 0.01 & 24 & 27.6 & 1.75 \\
\hline & 07 MAY1993 & 20 & 108.9 & 1.89 & 19 & 13.6 & 0.89 & 19 & 1.03 & 0.03 & 20 & 29.9 & 1.60 \\
\hline & 10MAY1993 & 20 & 106.3 & 1.58 & 20 & 12.1 & 0.51 & 20 & 1.00 & 0.02 & 20 & 21.2 & 1.57 \\
\hline & 12 MAY1993 & 19 & 104.9 & 1.59 & 18 & 12.2 & 0.55 & 18 & 1.05 & 0.02 & 18 & 24.3 & 1.63 \\
\hline & 14MAY1993 & 20 & 102.6 & 1.97 & 20 & 11.6 & 0.75 & 20 & 1.04 & 0.02 & 17 & 20.7 & 1.69 \\
\hline & 31 MAY1993 & 17 & 102.3 & 3.33 & 17 & 12.6 & 1.24 & 17 & 1.14 & 0.02 & 17 & 21.2 & 1.19 \\
\hline & 02JUN1993 & 18 & 103.6 & 2.65 & 18 & 12.4 & 1.07 & 18 & 1.07 & 0.02 & 16 & 23.0 & 1.94 \\
\hline & 04JUN1993 & 4 & 104.0 & 3.11 & 4 & 12.4 & 1.14 & 4 & 1.09 & 0.02 & 4 & 15.3 & 2.74 \\
\hline \multirow[t]{11}{*}{ SRT } & 06APR1993 & 40 & 107.0 & 1.44 & 40 & 14.3 & 0.54 & 40 & 1.15 & 0.01 & 39 & 18.7 & 1.05 \\
\hline & 07 APR1993 & 40 & 106.2 & 1.08 & 40 & 13.8 & 0.46 & 40 & 1.14 & 0.01 & 39 & 17.0 & 0.84 \\
\hline & 13APR1993 & 40 & 103.4 & 1.31 & 40 & 12.9 & 0.52 & 40 & 1.15 & 0.02 & 40 & 16.2 & 0.97 \\
\hline & 15APR1993 & 39 & 106.4 & 1.52 & 39 & 14.2 & 0.72 & 39 & 1.15 & 0.02 & 39 & 18.2 & 0.87 \\
\hline & 20APR1993 & 40 & 107.7 & 1.30 & 39 & 12.5 & 0.52 & 39 & 0.99 & 0.01 & 39 & 19.4 & 0.83 \\
\hline & 22APR1993 & 15 & 108.1 & 2.60 & 15 & 12.9 & 0.93 & 15 & 1.00 & 0.02 & 15 & 20.5 & 1.08 \\
\hline & 27APR1993 & 49 & 104.4 & 1.52 & 49 & 12.0 & 0.53 & 49 & 1.03 & 0.01 & 49 & 17.0 & 0.90 \\
\hline & 29APR1993 & 39 & 107.6 & 1.57 & 39 & 13.7 & 0.59 & 39 & 1.08 & 0.01 & 38 & 17.1 & 1.09 \\
\hline & 04 MAY1993 & 40 & 112.4 & 1.67 & 40 & 15.4 & 0.71 & 40 & 1.06 & 0.02 & 39 & 20.2 & 0.85 \\
\hline & 06 MAY1993 & 38 & 110.6 & 1.30 & 38 & 14.8 & 0.58 & 38 & 1.08 & 0.01 & 37 & 19.3 & 0.77 \\
\hline & 11 MAY1993 & 40 & 108.8 & 1.06 & 40 & 13.2 & 0.43 & 40 & 1.01 & 0.01 & 38 & 17.5 & 0.88 \\
\hline
\end{tabular}


Appendix C (continued)

\begin{tabular}{|c|c|c|c|c|c|c|c|c|c|c|c|c|c|}
\hline & & \multicolumn{3}{|c|}{ FORK LENGTH } & \multirow{2}{*}{\multicolumn{3}{|c|}{ WEIGHT }} & \multicolumn{3}{|c|}{ KFACTOR } & \multicolumn{3}{|c|}{ ATPase } \\
\hline & & & & & & & & \multirow[b]{2}{*}{$N$} & \multirow[b]{2}{*}{ MEAN } & \multirow{2}{*}{$\begin{array}{r}\text { STD - } \\
\text { ERR }\end{array}$} & \multirow[b]{2}{*}{ N } & \multirow[b]{2}{*}{ MEAN } & \multirow{2}{*}{$\begin{array}{r}\text { STD- } \\
\text { ERR }\end{array}$} \\
\hline & & N & MEAN & STDERR & N & MEAN & STDERR & & & & & & \\
\hline SITE & DATE & & & & & & & & & & & & \\
\hline \multirow[t]{12}{*}{ LGR } & 27APR 1993 & 22 & 122.8 & 3.55 & 22 & 17.8 & 0.98 & 22 & 0.97 & 0.03 & 22 & 33.2 & 1.75 \\
\hline & 29APR1993 & 20 & 115.6 & 2.32 & 20 & 15.5 & 0.98 & 20 & 0.98 & 0.01 & 20 & 31.0 & 2.55 \\
\hline & 04 MAY1993 & 20 & 118.3 & 2.14 & 20 & 16.5 & 0.84 & 20 & 0.99 & 0.01 & 20 & 29.2 & 1.98 \\
\hline & 06 MAY1993 & 20 & 114.7 & 1.39 & 20 & 15.2 & 0.57 & 20 & 1.00 & 0.01 & 20 & 28.3 & 1.69 \\
\hline & 11 MAY1993 & 21 & 113.6 & 1.85 & 20 & 15.2 & 0.70 & 20 & 1.03 & 0.02 & 20 & 29.0 & 1.38 \\
\hline & 13MAY1993 & 20 & 111.7 & 1.86 & 20 & 14.5 & 0.68 & 20 & 1.03 & 0.01 & 20 & 25.5 & 1.26 \\
\hline & 18MAY1993 & 18 & 112.9 & 1.86 & 18 & 14.9 & 0.68 & 18 & 1.03 & 0.02 & 18 & 25.1 & 1.11 \\
\hline & 20 MAY1993 & 20 & 108.8 & 1.27 & 20 & 13.3 & 0.55 & 20 & 1.02 & 0.02 & 20 & 28.2 & 1.36 \\
\hline & 25MAY1993 & 20 & 106.2 & 2.87 & 20 & 12.9 & 1.19 & 20 & 1.04 & 0.02 & 20 & 23.2 & 1.60 \\
\hline & 27MAY1993 & 19 & 111.1 & 1.58 & 19 & 14.2 & 0.71 & 19 & 1.02 & 0.02 & 19 & 25.5 & 1.29 \\
\hline & 01JUN1993 & 19 & 113.8 & 1.69 & 19 & 15.7 & 0.72 & 19 & 1.05 & 0.01 & 19 & 27.6 & 1.48 \\
\hline & 03JUN1993 & 18 & 113.6 & 2.07 & 18 & 15.6 & 0.78 & 18 & 1.05 & 0.01 & 18 & 28.5 & 1.19 \\
\hline
\end{tabular}


Appendix D. Summary of selected data from subyearling fall chinook salmon collected from the migration-atlarge at Bonneville Dam first powerhouse (BON), John Day Dam (JDA), McNary Dam (MCN), and Rock Island Dam (RIS) during spring 1993. Data includes sample size (N), mean (MEAN), and standard error (STDERR) of fork length in millimeters, wet weight in grams, condition factor (KFACTOR), and gill $\mathrm{Na}^{+}, \mathrm{K}^{+}-$ ATPase activity (ATPase) in $\mu \mathrm{mol} \mathrm{P}_{\mathrm{i}} \cdot \mathrm{mg} \operatorname{protein}^{-1} \cdot \mathrm{h}^{-1}$.

\begin{tabular}{|c|c|c|c|c|c|c|c|c|c|c|c|c|c|}
\hline & & \multirow{2}{*}{\multicolumn{3}{|c|}{ FORK LENGTH }} & \multirow{2}{*}{\multicolumn{3}{|c|}{ WEIGHT }} & \multicolumn{3}{|c|}{ KFACTOR } & \multicolumn{3}{|c|}{ ATPase } \\
\hline & & & & & & & & \multirow[b]{2}{*}{$\mathrm{N}$} & \multirow[b]{2}{*}{ MEAN } & \multirow{2}{*}{$\begin{array}{r}\text { STD - } \\
\text { ERR }\end{array}$} & \multirow[b]{2}{*}{$N$} & \multirow[b]{2}{*}{ MEAN } & \multirow{2}{*}{$\begin{array}{r}\text { STD - } \\
\text { ERR }\end{array}$} \\
\hline & & $N$ & MEAN & STDERR & N & MEAN & STDERR & & & & & & \\
\hline SITE & DATE & & & & & & & & & & & & \\
\hline \multirow[t]{9}{*}{ BON } & 15JUL1993 & 20 & 111.2 & 1.72 & 20 & 14.3 & 0.87 & 20 & 1.02 & 0.02 & 19 & 22.0 & 1.75 \\
\hline & 22JUL1993 & 20 & 114.0 & 2.90 & 20 & 15.8 & 1.17 & 20 & 1.03 & 0.02 & 20 & 29.3 & 2.00 \\
\hline & 28JUL1993 & 20 & 109.3 & 2.41 & 20 & 14.6 & 1.04 & 20 & 1.09 & 0.03 & 20 & 30.3 & 2.02 \\
\hline & 04AUG1993 & 20 & 122.7 & 3.33 & 20 & 21.9 & 2.23 & 20 & 1.12 & 0.02 & 20 & 31.5 & 2.14 \\
\hline & 11AUG1993 & 20 & 112.5 & 2.12 & 20 & 15.9 & 1.01 & 20 & 1.09 & 0.02 & 19 & 28.6 & 1.68 \\
\hline & 18AUG1993 & 20 & 119.0 & 2.70 & 20 & 19.0 & 1.37 & 20 & 1.10 & 0.02 & 20 & 24.1 & 1.36 \\
\hline & 25AUG1993 & 20 & 117.0 & 2.11 & 20 & 18.6 & 1.10 & 20 & 1.14 & 0.01 & 20 & 24.2 & 1.23 \\
\hline & 02 SEP1993 & 20 & 131.6 & 2.05 & 20 & 26.1 & 1.30 & 20 & 1.13 & 0.02 & 20 & 22.5 & 1.51 \\
\hline & 08 SEP1993 & 20 & 131.9 & 2.66 & 20 & 26.6 & 1.57 & 20 & 1.13 & 0.02 & 20 & 25.1 & 1.71 \\
\hline \multirow[t]{11}{*}{ JDA } & 22JUN1993 & 20 & 111.5 & 1.35 & 19 & 14.9 & 0.54 & 19 & 1.08 & 0.01 & 19 & 20.7 & 1.18 \\
\hline & 29JUN1993 & 20 & 108.8 & 1.66 & 20 & 13.6 & 0.72 & 20 & 1.03 & 0.02 & 19 & 25.1 & 1.68 \\
\hline & 06JUL1993 & 20 & 100.7 & 1.46 & 20 & 10.1 & 0.41 & 20 & 0.98 & 0.01 & 20 & 28.6 & 1.44 \\
\hline & 13JUL1993 & 20 & 102.3 & 1.43 & 20 & 12.6 & 0.56 & 20 & 1.16 & 0.02 & 20 & 26.2 & 1.75 \\
\hline & 20JUL1993 & 20 & 108.2 & 1.52 & 20 & 14.3 & 0.74 & 20 & 1.11 & 0.02 & 19 & 28.9 & 1.67 \\
\hline & 27JUL1993 & 20 & 118.8 & 1.80 & 20 & 21.4 & 1.20 & 20 & 1.25 & 0.03 & 20 & 27.0 & 2.07 \\
\hline & 03AUG1993 & 20 & 125.9 & 1.33 & 20 & 25.9 & 0.86 & 20 & 1.29 & 0.01 & 20 & 29.5 & 1.71 \\
\hline & 10AUG1993 & 20 & 125.7 & 1.26 & 20 & 24.7 & 0.81 & 20 & 1.24 & 0.01 & 20 & 28.5 & 1.39 \\
\hline & 17 AUG1993 & 20 & 129.8 & 1.36 & 20 & 25.1 & 0.98 & 20 & 1.14 & 0.02 & 20 & 17.7 & 1.79 \\
\hline & 24AUG1993 & 20 & 130.8 & 1.33 & 20 & 27.3 & 1.01 & 20 & 1.21 & 0.02 & 20 & 20.2 & 1.05 \\
\hline & 31AUG1993 & 10 & 132.0 & 3.22 & 10 & 26.9 & 2.75 & 10 & 1.13 & 0.04 & 10 & 17.5 & 2.54 \\
\hline \multirow[t]{18}{*}{ MCN } & 16JUN1993 & 20 & 106.0 & 3.59 & 20 & 13.7 & 1.34 & 20 & 1.07 & 0.01 & 20 & 28.3 & 1.57 \\
\hline & 23JUN1993 & 20 & 106.2 & 0.92 & 20 & 12.5 & 0.40 & 20 & 1.04 & 0.01 & 20 & 26.4 & 1.52 \\
\hline & 30JUN1993 & 40 & 99.2 & 0.94 & 40 & 9.5 & 0.26 & 40 & 0.96 & 0.01 & 38 & 25.3 & 0.83 \\
\hline & 04JUL1993 & 22 & 97.0 & 0.83 & 22 & 8.7 & 0.24 & 22 & 0.95 & 0.01 & 22 & 23.1 & 0.83 \\
\hline & 06JUL 1993 & 21 & 97.0 & 1.39 & 21 & 9.0 & 0.42 & 21 & 0.97 & 0.01 & 21 & 25.1 & 1.64 \\
\hline & 07JUL1993 & 31 & 97.2 & 1.05 & 31 & 9.2 & 0.35 & 31 & 0.99 & 0.01 & 28 & 22.3 & 0.73 \\
\hline & 08JUL1993 & 17 & 96.8 & 1.19 & 17 & 8.7 & 0.32 & 17 & 0.95 & 0.01 & 17 & 31.7 & 1.74 \\
\hline & 09JUL1993 & 9 & 96.1 & 1.78 & 9 & 8.5 & 0.51 & 9 & 0.95 & 0.02 & 9 & 30.8 & 3.33 \\
\hline & 14JUL1993 & 20 & 100.5 & 1.76 & 20 & 10.3 & 0.49 & 20 & 1.00 & 0.01 & 20 & 28.9 & 1.27 \\
\hline & 21JUL 1993 & 20 & 105.6 & 1.63 & 20 & 13.3 & 0.63 & 20 & 1.12 & 0.01 & 20 & 27.2 & 2.09 \\
\hline & 28JUL1993 & 20 & 114.9 & 1.24 & 20 & 17.6 & 0.59 & 20 & 1.15 & 0.01 & 19 & 26.1 & 1.63 \\
\hline & 04AUG1993 & 20 & 121.0 & 0.71 & 20 & 21.1 & 0.49 & 20 & 1.19 & 0.01 & 19 & 29.1 & 1.88 \\
\hline & 11AUG1993 & 20 & 120.1 & 0.84 & 20 & 21.1 & 0.45 & 20 & 1.21 & 0.01 & 20 & 23.7 & 1.40 \\
\hline & 18 AUG1993 & 20 & 130.0 & 1.74 & 20 & 27.5 & 1.30 & 20 & 1.24 & 0.01 & 20 & 22.5 & 1.28 \\
\hline & 25AUG1993 & 20 & 129.2 & 1.68 & 20 & 26.9 & 1.16 & 20 & 1.23 & 0.02 & 20 & 18.7 & 1.14 \\
\hline & 01 SEP1993 & 20 & 136.9 & 2.27 & 20 & 30.6 & 1.69 & 20 & 1.17 & 0.02 & 20 & 22.9 & 1.79 \\
\hline & $120 \mathrm{CT} 1993$ & 20 & 151.6 & 2.68 & 20 & 39.7 & 2.77 & 20 & 1.11 & 0.02 & 20 & 15.2 & 1.20 \\
\hline & 19NOV1993 & 20 & 166.6 & 2.92 & 5 & 45.1 & 5.38 & 5 & 1.08 & 0.02 & 11 & 18.6 & 2.19 \\
\hline \multirow[t]{10}{*}{ RIS } & 25JUN1993 & 10 & 87.8 & 9.06 & 10 & 9.5 & 3.38 & 10 & 1.04 & 0.03 & 7 & 24.0 & 0.96 \\
\hline & 28JUN1993 & 10 & 94.5 & 7.72 & 10 & 11.2 & 2.66 & 10 & 1.11 & 0.02 & 10 & 21.2 & 1.85 \\
\hline & 29JUN1993 & 10 & 92.4 & 7.28 & 10 & 10.0 & 3.00 & 10 & 1.04 & 0.02 & 10 & 24.6 & 1.05 \\
\hline & 30JUN1993 & 10 & 111.3 & 9.67 & 10 & 18.2 & 4.25 & 10 & 1.08 & 0.02 & 10 & 19.0 & 1.71 \\
\hline & 06JUL 1993 & 9 & 95.8 & 3.41 & 9 & 10.2 & 0.92 & 9 & 1.14 & 0.03 & 9 & 13.2 & 1.14 \\
\hline & 07JUL 1993 & 10 & 106.3 & 7.34 & 10 & 14.9 & 3.29 & 10 & 1.11 & 0.02 & 10 & 19.9 & 2.49 \\
\hline & 08JUL1993 & 10 & 90.6 & 3.53 & 10 & 8.5 & 0.93 & 10 & 1.12 & 0.03 & 10 & 18.9 & 1.02 \\
\hline & 12JUL1993 & 10 & 86.4 & 4.38 & 10 & 8.0 & 1.24 & 10 & 1.16 & 0.04 & 9 & 22.9 & 1.52 \\
\hline & 13JUL1993 & 10 & 85.1 & 2.87 & 10 & 6.5 & 0.70 & 10 & 1.03 & 0.02 & 10 & 25.5 & 2.61 \\
\hline & 14JUL 1993 & 10 & 85.0 & 1.56 & 10 & 6.6 & 0.46 & 10 & 1.06 & 0.02 & 10 & 20.7 & 1.61 \\
\hline
\end{tabular}


Appendix D (continued)

\begin{tabular}{|c|c|c|c|c|c|c|c|c|c|c|c|c|c|}
\hline & & \multirow{2}{*}{\multicolumn{3}{|c|}{ FORK LENGTH }} & \multirow{2}{*}{\multicolumn{3}{|c|}{ WEIGHT }} & \multicolumn{3}{|c|}{ KFACTOR } & \multicolumn{3}{|c|}{ ATPase } \\
\hline & & & & & & & & \multirow[b]{2}{*}{$N$} & \multirow[b]{2}{*}{ MEAN } & \multirow{2}{*}{$\begin{array}{r}\text { STD - } \\
\text { ERR }\end{array}$} & \multirow[b]{2}{*}{$N$} & \multirow[b]{2}{*}{ MEAN } & \multirow{2}{*}{$\begin{array}{r}\text { STD - } \\
\text { ERR }\end{array}$} \\
\hline & & N & MEAN & STDERR & N & MEAN & STDERR & & & & & & \\
\hline SITE & DATE & & & & & & & & & & & & \\
\hline \multirow[t]{4}{*}{ RIS } & 19JUL1993 & 10 & 94.0 & 4.56 & 10 & 9.4 & 1.40 & 10 & 1.07 & 0.02 & 10 & 21.6 & 2.00 \\
\hline & 20JUL1993 & 10 & 101.3 & 2.50 & 10 & 11.3 & 0.90 & 10 & 1.07 & 0.02 & 10 & 20.6 & 2.58 \\
\hline & 21JUL1993 & 10 & 93.5 & 4.17 & 10 & 9.2 & 1.48 & 10 & 1.04 & 0.04 & 10 & 23.0 & 1.35 \\
\hline & 26JUL1993 & 10 & 95.0 & 3.64 & 10 & 9.8 & 1.25 & 10 & 1.10 & 0.02 & 10 & 24.5 & 1.67 \\
\hline
\end{tabular}


Appendix E. Summary of selected data from hatchery steelhead collected from the migration-at-large at the Clearwater River trap (CLW), Snake River Trap at Lewiston (LEW), Salmon River Trap (SRT), Lower Granite Dam (LGR), Little Goose Dam (LGS), McNary Dam (MCN), and Rock Island Dam (RIS) during spring 1993. Data includes sample size (N), mean (MEAN), and standard error (STDERR) of fork length in millimeters, wet weight in grams, condition factor (KFACTOR), and gill $\mathrm{Na}^{+}, \mathrm{K}^{+}$-ATPase activity (ATPase) in $\mu \mathrm{mol} \mathrm{P}_{\mathrm{i}} \cdot \mathrm{mg}_{\text {protein }}{ }^{-1} \cdot \mathrm{h}^{-1}$.

\begin{tabular}{|c|c|c|c|c|c|c|c|c|c|c|c|c|c|}
\hline & & \multirow{2}{*}{\multicolumn{3}{|c|}{ FORK LENGTH }} & \multirow{2}{*}{\multicolumn{3}{|c|}{ WEIGHT }} & \multicolumn{3}{|c|}{ KFACTOR } & \multicolumn{3}{|c|}{ ATPase } \\
\hline & & & & & & & & \multirow[b]{2}{*}{$N$} & \multirow[b]{2}{*}{ MEAN } & \multirow{2}{*}{$\begin{array}{r}\text { STD - } \\
\text { ERR }\end{array}$} & \multirow[b]{2}{*}{$N$} & \multirow[b]{2}{*}{ MEAN } & \multirow{2}{*}{$\begin{array}{r}\text { STD - } \\
\text { ERR }\end{array}$} \\
\hline & & $N$ & MEAN & STDERR & $N$ & MEAN & STDERR & & & & & & \\
\hline SITE & DATE & & & & & & & & & & & & \\
\hline CLW & 26APR 1993 & 1 & 120.0 & . & 0 & . & . & 0 &. &. & 1 & 16.7 & . \\
\hline \multirow[t]{16}{*}{ LEW } & 16APR1993 & 12 & 223.3 & 4.87 & 12 & 105.3 & 6.90 & 12 & 0.93 & 0.02 & 12 & 11.4 & 0.94 \\
\hline & 19APR1993 & 14 & 198.2 & 5.80 & 14 & 79.4 & 6.06 & 14 & 0.99 & 0.01 & 14 & 11.9 & 1.07 \\
\hline & 21APR1993 & 12 & 207.2 & 4.66 & 12 & 89.7 & 6.38 & 12 & 0.99 & 0.02 & 12 & 11.2 & 1.37 \\
\hline & 23APR1993 & 12 & 202.5 & 6.87 & 12 & 82.6 & 9.86 & 12 & 0.94 & 0.02 & 12 & 10.1 & 1.50 \\
\hline & 26APR1993 & 13 & 203.8 & 2.93 & 13 & 78.9 & 4.00 & 13 & 0.92 & 0.02 & 13 & 14.3 & 1.62 \\
\hline & 28APR 1993 & 18 & 196.5 & 1.95 & 18 & 71.8 & 2.38 & 18 & 0.94 & 0.01 & 18 & 14.0 & 1.10 \\
\hline & 30APR1993 & 12 & 194.6 & 5.36 & 12 & 72.9 & 5.47 & 12 & 0.97 & 0.01 & 12 & 14.7 & 2.49 \\
\hline & 03 MAY1993 & 12 & 215.7 & 5.69 & 12 & 93.9 & 7.35 & 12 & 0.91 & 0.02 & 12 & 12.1 & 1.38 \\
\hline & 05 MAY1993 & 12 & 210.6 & 9.38 & 12 & 92.3 & 13.37 & 12 & 0.92 & 0.02 & 12 & 10.7 & 1.56 \\
\hline & 07 MAY1993 & 12 & 225.1 & 7.10 & 12 & 102.8 & 10.91 & 12 & 0.87 & 0.01 & 12 & 11.4 & 1.03 \\
\hline & 10MAY1993 & 12 & 216.8 & 4.40 & 11 & 90.2 & 6.35 & 11 & 0.89 & 0.02 & 12 & 11.3 & 0.84 \\
\hline & 12 MAY1993 & 11 & 221.4 & 7.81 & 11 & 95.2 & 10.59 & 11 & 0.85 & 0.01 & 12 & 16.2 & 1.06 \\
\hline & 14MAY1993 & 12 & 224.7 & 5.98 & 12 & 96.2 & 7.77 & 12 & 0.83 & 0.01 & 12 & 14.4 & 1.32 \\
\hline & 31 MAY1993 & 12 & 200.7 & 10.59 & 12 & 73.9 & 14.68 & 12 & 0.82 & 0.01 & 12 & 17.6 & 1.70 \\
\hline & 02JUN1993 & 12 & 190.5 & 4.59 & 12 & 56.2 & 4.22 & 12 & 0.80 & 0.02 & 12 & 17.7 & 1.46 \\
\hline & 04JUN1993 & 12 & 195.6 & 7.78 & 12 & 64.5 & 7.23 & 12 & 0.82 & 0.01 & 12 & 19.6 & 1.89 \\
\hline \multirow[t]{8}{*}{ SRT } & 15APR 1993 & 25 & 225.5 & 4.20 & 25 & 115.1 & 6.83 & 25 & 0.98 & 0.01 & 25 & 6.8 & 0.45 \\
\hline & 20APR1993 & 24 & 210.2 & 3.42 & 24 & 88.0 & 5.11 & 24 & 0.93 & 0.01 & 24 & 8.7 & 0.93 \\
\hline & 22APR1993 & 25 & 208.3 & 3.06 & 25 & 85.0 & 3.86 & 25 & 0.92 & 0.01 & 25 & 10.5 & 0.79 \\
\hline & 27APR1993 & 36 & 206.8 & 2.82 & 36 & 83.7 & 3.66 & 36 & 0.93 & 0.01 & 36 & 8.6 & 0.56 \\
\hline & 29APR1993 & 25 & 204.1 & 3.25 & 25 & 77.1 & 3.96 & 25 & 0.89 & 0.01 & 24 & 11.7 & 0.84 \\
\hline & 04 MAY1993 & 25 & 210.1 & 3.00 & 25 & 80.7 & 3.68 & 25 & 0.86 & 0.01 & 25 & 12.8 & 0.80 \\
\hline & 06 MAY1993 & 25 & 205.4 & 4.19 & 25 & 77.2 & 5.29 & 25 & 0.86 & 0.01 & 25 & 12.2 & 0.72 \\
\hline & 11 MAY1993 & 25 & 206.3 & 4.29 & 25 & 77.9 & 5.00 & 25 & 0.86 & 0.01 & 25 & 12.2 & 1.04 \\
\hline \multirow[t]{12}{*}{ LGR } & 27APR1993 & 20 & 205.4 & 4.71 & 20 & 80.7 & 5.40 & 20 & 0.90 & 0.01 & 19 & 12.9 & 1.02 \\
\hline & 29APR1993 & 20 & 214.6 & 5.11 & 19 & 92.8 & 7.45 & 19 & 0.91 & 0.01 & 20 & 13.8 & 0.90 \\
\hline & 04 MAY1993 & 20 & 216.4 & 4.59 & 20 & 91.8 & 5.85 & 20 & 0.89 & 0.02 & 20 & 17.2 & 1.53 \\
\hline & 06 MAY1993 & 20 & 212.2 & 6.02 & 20 & 89.9 & 7.51 & 20 & 0.89 & 0.01 & 20 & 16.0 & 1.07 \\
\hline & 11 MAY1993 & 21 & 213.5 & 4.77 & 20 & 88.7 & 6.24 & 20 & 0.86 & 0.01 & 21 & 16.5 & 0.99 \\
\hline & 13 MAY1993 & 20 & 217.2 & 5.40 & 20 & 92.0 & 7.55 & 20 & 0.86 & 0.01 & 20 & 20.3 & 1.65 \\
\hline & $18 M A Y 1993$ & 20 & 197.0 & 5.14 & 20 & 66.9 & 5.13 & 20 & 0.84 & 0.01 & 20 & 15.9 & 1.33 \\
\hline & 20MAY1993 & 20 & 210.1 & 3.71 & 20 & 81.2 & 4.32 & 20 & 0.86 & 0.01 & 20 & 16.6 & 1.10 \\
\hline & 25 MAY1993 & 20 & 204.1 & 4.79 & 20 & 73.3 & 5.44 & 20 & 0.83 & 0.01 & 19 & 18.7 & 1.32 \\
\hline & 27MAY1993 & 13 & 203.2 & 5.41 & 13 & 70.3 & 6.14 & 13 & 0.81 & 0.02 & 13 & 14.6 & 1.23 \\
\hline & 01JUN1993 & 20 & 224.4 & 5.79 & 20 & 98.6 & 8.79 & 20 & 0.83 & 0.01 & 20 & 18.7 & 1.11 \\
\hline & 03JUN1993 & 20 & 196.3 & 5.27 & 19 & 64.7 & 5.50 & 19 & 0.81 & 0.02 & 20 & 19.9 & 1.25 \\
\hline \multirow[t]{11}{*}{ LGS } & 30APR1993 & 12 & 195.4 & 7.86 & 12 & 66.3 & 8.14 & 12 & 0.84 & 0.01 & 12 & 16.0 & 1.32 \\
\hline & 03 MAY1993 & 12 & 193.3 & 6.90 & 12 & 63.6 & 7.96 & 12 & 0.83 & 0.02 & 12 & 19.6 & 1.60 \\
\hline & 05 MAY1993 & 12 & 216.8 & 7.23 & 12 & 91.5 & 9.38 & 12 & 0.86 & 0.02 & 12 & 23.2 & 1.33 \\
\hline & 07 MAY1993 & 12 & 196.8 & 5.91 & 12 & 67.0 & 8.45 & 12 & 0.84 & 0.02 & 12 & 22.4 & 1.82 \\
\hline & 10MAY1993 & 12 & 205.5 & 8.07 & 12 & 79.8 & 11.33 & 12 & 0.86 & 0.02 & 12 & 16.9 & 1.97 \\
\hline & 12 MAY1993 & 12 & 216.8 & 6.47 & 12 & 90.3 & 9.49 & 12 & 0.85 & 0.02 & 12 & 18.0 & 1.59 \\
\hline & 14MAY1993 & 12 & 205.3 & 6.21 & 12 & 72.1 & 6.71 & 12 & 0.81 & 0.01 & 12 & 15.7 & 1.15 \\
\hline & 17MAY1993 & 12 & 205.7 & 5.36 & 12 & 74.4 & 6.37 & 12 & 0.83 & 0.01 & 12 & 18.3 & 1.16 \\
\hline & 19 MAY1993 & 12 & 203.8 & 4.57 & 12 & 71.3 & 4.40 & 12 & 0.83 & 0.02 & 12 & 16.9 & 0.86 \\
\hline & 21 MAY1993 & 12 & 202.8 & 6.47 & 12 & 70.1 & 8.13 & 12 & 0.81 & 0.02 & 12 & 19.6 & 1.40 \\
\hline & 24MAY1993 & 12 & 208.8 & 6.22 & 12 & 71.1 & 6.17 & 12 & 0.76 & 0.01 & 12 & 22.7 & 2.36 \\
\hline
\end{tabular}


Appendix E (continued)

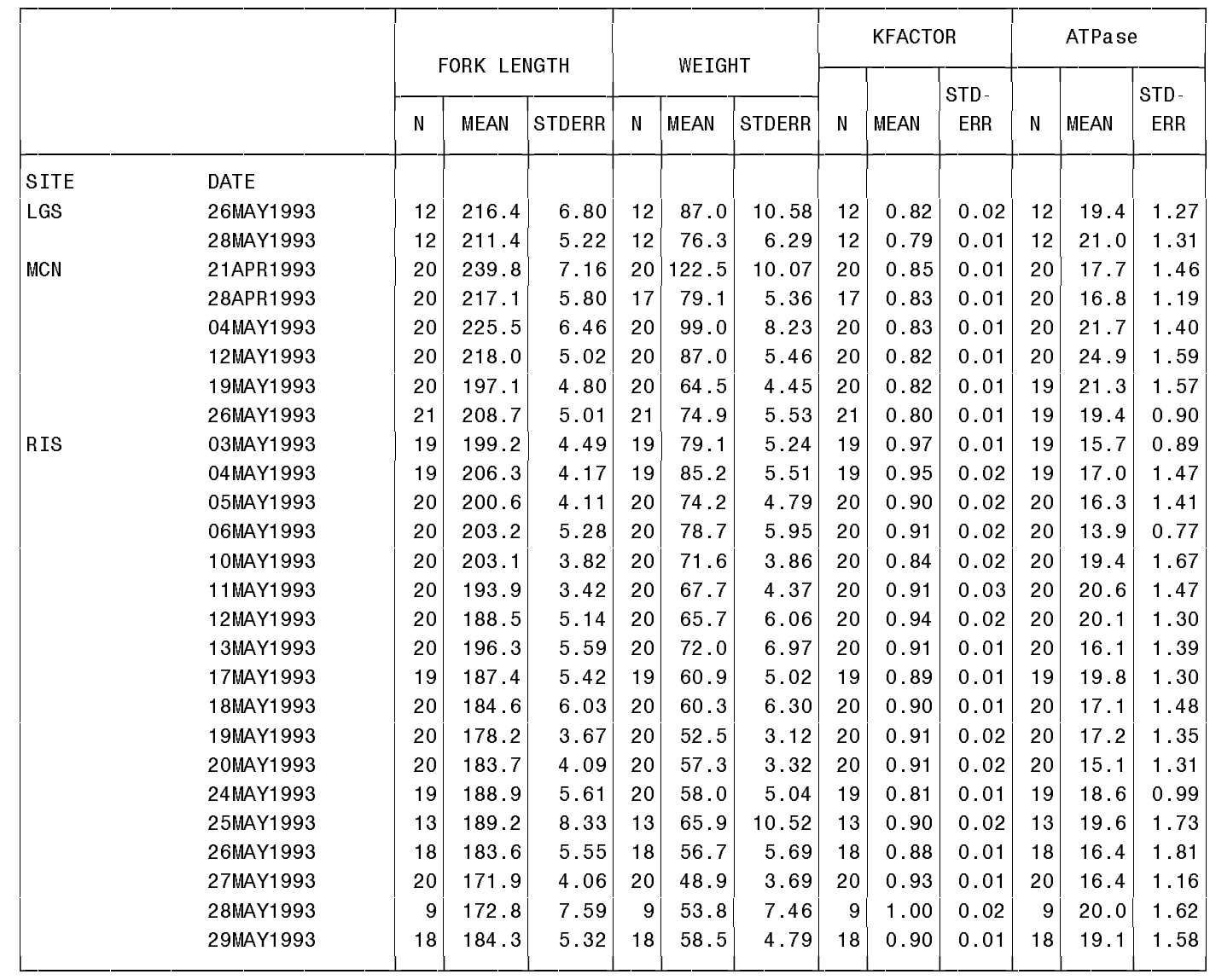


Appendix F. Summary of selected data from wild steelhead collected from the migration-at-large at the Clearwater River Trap (CLW), Snake River Trap at Lewiston (LEW), Salmon River Trap (SRT), Lower Granite Dam (LGR), Little Goose Dam (LGS), McNary Dam (MCN), and Rock Island Dam (RIS) during spring 1993. Data includes sample size (N), mean (MEAN), and standard error (STDERR) of fork length in millimeters, wet weight in grams, condition factor (KFACTOR), and gill $\mathrm{Na}^{+}, \mathrm{K}^{+}$-ATPase activity (ATPase) in $\mu \mathrm{mol} \mathrm{P}_{\mathrm{i}} \cdot \mathrm{mg}_{\text {protein }}{ }^{-1} \cdot \mathrm{h}^{-1}$.

\begin{tabular}{|c|c|c|c|c|c|c|c|c|c|c|c|c|c|}
\hline & & \multirow{2}{*}{\multicolumn{3}{|c|}{ FORK LENGTH }} & \multirow{2}{*}{\multicolumn{3}{|c|}{ WEIGHT }} & \multicolumn{3}{|c|}{ KFACTOR } & \multicolumn{3}{|c|}{ ATPase } \\
\hline & & & & & & & & \multirow[b]{2}{*}{$N$} & \multirow[b]{2}{*}{ MEAN } & \multirow{2}{*}{$\begin{array}{r}\text { STD - } \\
\text { ERR }\end{array}$} & \multirow[b]{2}{*}{$N$} & \multirow[b]{2}{*}{ MEAN } & \multirow{2}{*}{$\begin{array}{r}\text { STD - } \\
\text { ERR }\end{array}$} \\
\hline & & $N$ & MEAN & STDERR & $N$ & MEAN & STDERR & & & & & & \\
\hline SITE & DATE & & & & & & & & & & & & \\
\hline CLW & 28APR 1993 & 1 & 157.0 & . & 1 & 37.0 & . & 1 & 0.96 &. & 1 & 15.3 & . \\
\hline \multirow[t]{14}{*}{ LEW } & 16APR1993 & 7 & 192.0 & 13.80 & 7 & 71.7 & 16.89 & 7 & 0.91 & 0.02 & 7 & 18.7 & 3.44 \\
\hline & 19APR1993 & 10 & 192.3 & 9.89 & 10 & 68.5 & 9.22 & 10 & 0.92 & 0.02 & 10 & 17.1 & 2.20 \\
\hline & 21APR1993 & 12 & 180.2 & 3.98 & 11 & 55.1 & 3.41 & 11 & 0.92 & 0.01 & 12 & 22.3 & 1.35 \\
\hline & 23APR1993 & 10 & 161.6 & 5.26 & 10 & 38.3 & 3.43 & 10 & 0.89 & 0.01 & 10 & 18.7 & 1.20 \\
\hline & 26APR1993 & 16 & 176.6 & 5.43 & 16 & 52.1 & 5.69 & 16 & 0.91 & 0.01 & 16 & 22.2 & 1.70 \\
\hline & 28APR 1993 & 18 & 164.3 & 3.70 & 18 & 42.1 & 2.47 & 18 & 0.93 & 0.02 & 18 & 21.8 & 1.10 \\
\hline & 30APR1993 & 12 & 178.4 & 4.03 & 12 & 53.1 & 3.91 & 12 & 0.92 & 0.03 & 12 & 24.2 & 2.67 \\
\hline & 03MAY1993 & 12 & 177.3 & 3.92 & 11 & 48.0 & 3.28 & 11 & 0.87 & 0.02 & 12 & 16.5 & 0.84 \\
\hline & 05 MAY1993 & 16 & 181.5 & 6.67 & 16 & 57.3 & 7.22 & 16 & 0.90 & 0.01 & 16 & 15.7 & 0.99 \\
\hline & 07 MAY1993 & 17 & 174.2 & 4.55 & 17 & 47.7 & 3.65 & 17 & 0.88 & 0.01 & 17 & 13.9 & 1.03 \\
\hline & 10MAY1993 & 12 & 177.3 & 4.95 & 12 & 48.7 & 4.45 & 12 & 0.85 & 0.02 & 12 & 17.5 & 1.66 \\
\hline & $12 M A Y 1993$ & 12 & 169.8 & 4.90 & 12 & 44.8 & 3.24 & 12 & 0.90 & 0.02 & 12 & 17.6 & 1.53 \\
\hline & 14MAY1993 & 12 & 169.6 & 4.66 & 12 & 41.4 & 2.72 & 12 & 0.84 & 0.02 & 12 & 18.1 & 1.34 \\
\hline & 04JUN1993 & 3 & 166.3 & 13.09 & 3 & 46.2 & 12.57 & 3 & 0.95 & 0.03 & 3 & 23.9 & 7.14 \\
\hline \multirow[t]{8}{*}{ SRT } & 06APR 1993 & 1 & 145.0 & & 1 & 29.1 & & 1 & 0.96 & & 1 & 10.5 & . \\
\hline & 20APR1993 & 13 & 185.2 & 8.63 & 13 & 63.5 & 11.39 & 13 & 0.91 & 0.02 & 13 & 13.0 & 1.18 \\
\hline & 22APR 1993 & 1 & 171.0 &. & 1 & 48.1 &. & 1 & 0.96 & 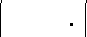 & 1 & 11.9 & . \\
\hline & 27APR1993 & 12 & 170.9 & 2.81 & 12 & 42.1 & 2.21 & 12 & 0.83 & 0.02 & 12 & 13.8 & 1.62 \\
\hline & 29APR1993 & 7 & 173.7 & 5.40 & 7 & 43.5 & 3.70 & 7 & 0.82 & 0.01 & 7 & 14.0 & 1.34 \\
\hline & 04 MAY1993 & 25 & 178.3 & 3.67 & 25 & 50.6 & 3.33 & 25 & 0.87 & 0.02 & 25 & 14.5 & 0.88 \\
\hline & 06 MAY1993 & 34 & 173.8 & 2.64 & 34 & 46.9 & 2.17 & 34 & 0.88 & 0.01 & 34 & 12.6 & 0.74 \\
\hline & 11 MAY1993 & 25 & 174.6 & 3.09 & 25 & 47.9 & 2.50 & 25 & 0.88 & 0.01 & 25 & 15.9 & 0.81 \\
\hline \multirow[t]{12}{*}{ LGR } & 27APR 1993 & 20 & 183.7 & 5.53 & 20 & 57.5 & 5.48 & 20 & 0.88 & 0.01 & 20 & 20.0 & 1.27 \\
\hline & 29APR 1993 & 20 & 181.6 & 4.61 & 20 & 53.5 & 4.65 & 20 & 0.85 & 0.01 & 20 & 23.6 & 1.82 \\
\hline & 04 MAY1993 & 20 & 182.2 & 4.92 & 20 & 52.7 & 4.35 & 20 & 0.84 & 0.01 & 20 & 24.8 & 1.35 \\
\hline & 06 MAY1993 & 20 & 181.0 & 2.73 & 19 & 51.7 & 2.73 & 19 & 0.86 & 0.01 & 20 & 22.9 & 1.31 \\
\hline & 11 MAY1993 & 20 & 178.0 & 4.93 & 20 & 52.1 & 4.41 & 20 & 0.88 & 0.02 & 20 & 20.5 & 1.46 \\
\hline & 13 MAY1993 & 20 & 174.2 & 3.13 & 20 & 47.4 & 2.68 & 20 & 0.88 & 0.01 & 20 & 26.1 & 1.55 \\
\hline & 18 MAY1993 & 20 & 163.1 & 3.50 & 20 & 39.0 & 2.60 & 20 & 0.88 & 0.02 & 20 & 20.0 & 1.28 \\
\hline & $20 M A Y 1993$ & 20 & 166.2 & 2.52 & 20 & 42.2 & 1.96 & 20 & 0.91 & 0.02 & 20 & 21.9 & 1.28 \\
\hline & 25 MAY1993 & 20 & 160.4 & 3.02 & 20 & 38.5 & 2.34 & 20 & 0.92 & 0.01 & 19 & 20.6 & 1.43 \\
\hline & 27MAY1993 & 20 & 166.6 & 4.11 & 20 & 43.7 & 3.29 & 20 & 0.91 & 0.01 & 20 & 22.0 & 1.31 \\
\hline & 01JUN1993 & 20 & 173.7 & 4.01 & 20 & 48.7 & 3.63 & 20 & 0.90 & 0.01 & 20 & 24.5 & 1.54 \\
\hline & 03JUN1993 & 20 & 166.3 & 2.73 & 20 & 41.7 & 2.09 & 20 & 0.89 & 0.01 & 19 & 24.6 & 1.45 \\
\hline \multirow[t]{13}{*}{ LGS } & 26APR1993 & 12 & 177.0 & 5.64 & 11 & 47.1 & 4.89 & 11 & 0.82 & 0.01 & 12 & 25.0 & 2.33 \\
\hline & 28APR1993 & 12 & 173.1 & 5.33 & 12 & 43.3 & 4.22 & 12 & 0.81 & 0.01 & 12 & 24.1 & 2.82 \\
\hline & 30APR1993 & 12 & 184.3 & 4.02 & 12 & 51.7 & 3.75 & 12 & 0.81 & 0.01 & 12 & 24.8 & 1.55 \\
\hline & 03 MAY1993 & 12 & 175.7 & 4.89 & 12 & 45.9 & 3.75 & 12 & 0.83 & 0.02 & 12 & 28.2 & 1.83 \\
\hline & 05 MAY1993 & 12 & 194.1 & 7.90 & 12 & 64.2 & 9.44 & 12 & 0.83 & 0.02 & 12 & 25.6 & 1.79 \\
\hline & 07 MAY1993 & 12 & 183.1 & 6.67 & 12 & 54.2 & 6.36 & 12 & 0.85 & 0.02 & 12 & 27.6 & 1.58 \\
\hline & 10MAY1993 & 12 & 171.8 & 4.19 & 12 & 43.4 & 3.51 & 12 & 0.84 & 0.02 & 12 & 21.8 & 1.73 \\
\hline & 12 MAY1993 & 12 & 177.0 & 4.06 & 12 & 47.6 & 3.55 & 12 & 0.84 & 0.01 & 12 & 21.9 & 1.57 \\
\hline & 14MAY1993 & 12 & 174.8 & 6.20 & 12 & 43.9 & 5.14 & 12 & 0.79 & 0.01 & 12 & 23.4 & 1.34 \\
\hline & 17MAY1993 & 12 & 167.1 & 4.08 & 12 & 40.9 & 3.15 & 12 & 0.86 & 0.01 & 12 & 22.5 & 1.27 \\
\hline & 19 MAY1993 & 12 & 170.1 & 3.62 & 12 & 42.4 & 2.72 & 12 & 0.85 & 0.01 & 12 & 21.6 & 1.71 \\
\hline & 21 MAY1993 & 12 & 166.0 & 5.94 & 12 & 37.8 & 3.49 & 12 & 0.81 & 0.02 & 12 & 23.7 & 1.37 \\
\hline & 24MAY1993 & 12 & 173.3 & 4.98 & 12 & 44.3 & 3.95 & 12 & 0.83 & 0.01 & 12 & 23.7 & 2.52 \\
\hline
\end{tabular}


Appendix F (continued)

\begin{tabular}{|c|c|c|c|c|c|c|c|c|c|c|c|c|c|}
\hline & & \multicolumn{3}{|c|}{ FORK LENGTH } & \multicolumn{3}{|c|}{ WEIGHT } & \multicolumn{3}{|c|}{ KFACTOR } & \multicolumn{3}{|c|}{ ATPase } \\
\hline & & N & MEAN & STDERR & $N$ & MEAN & STDERR & N & MEAN & $\begin{array}{r}\text { STD - } \\
\text { ERR }\end{array}$ & $N$ & MEAN & $\begin{array}{r}\text { STD - } \\
\text { ERR }\end{array}$ \\
\hline SITE & DATE & & & & & & & & & & & & \\
\hline \multirow[t]{2}{*}{ LGS } & 26MAY1993 & 13 & 169.5 & 4.86 & 13 & 44.1 & 4.32 & 13 & 0.87 & 0.02 & 13 & 23.4 & 1.96 \\
\hline & 28MAY1993 & 11 & 162.3 & 2.50 & 11 & 35.8 & 1.50 & 11 & 0.84 & 0.02 & 11 & 19.4 & 1.98 \\
\hline \multirow[t]{6}{*}{ MCN } & 21 APR1993 & 19 & 191.1 & 7.82 & 19 & 67.2 & 9.82 & 19 & 0.87 & 0.02 & 20 & 28.9 & 1.97 \\
\hline & 28APR 1993 & 20 & 188.1 & 4.11 & 20 & 56.6 & 3.28 & 20 & 0.84 & 0.02 & 19 & 27.0 & 2.82 \\
\hline & 04 MAY1993 & 20 & 184.1 & 3.44 & 20 & 54.1 & 3.30 & 20 & 0.85 & 0.02 & 20 & 25.8 & 2.12 \\
\hline & 12 MAY1993 & 20 & 181.3 & 5.31 & 20 & 52.5 & 4.35 & 20 & 0.85 & 0.02 & 20 & 26.8 & 2.15 \\
\hline & 19MAY1993 & 20 & 170.9 & 3.18 & 20 & 42.8 & 3.01 & 20 & 0.83 & 0.02 & 19 & 25.3 & 1.66 \\
\hline & 26MAY1993 & 19 & 176.3 & 4.79 & 19 & 50.8 & 4.33 & 19 & 0.89 & 0.01 & 19 & 20.7 & 1.47 \\
\hline \multirow[t]{18}{*}{ RIS } & 03MAY1993 & 8 & 169.1 & 6.97 & 8 & 45.0 & 5.69 & 8 & 0.89 & 0.02 & 8 & 13.3 & 1.55 \\
\hline & 04 MAY1993 & 17 & 172.5 & 6.58 & 17 & 48.0 & 5.24 & 17 & 0.88 & 0.02 & 17 & 19.0 & 1.79 \\
\hline & 05 MAY1993 & 20 & 164.1 & 4.20 & 20 & 40.9 & 3.45 & 20 & 0.89 & 0.01 & 20 & 17.0 & 1.21 \\
\hline & 06 MAY1993 & 20 & 179.3 & 5.92 & 20 & 54.1 & 5.88 & 20 & 0.88 & 0.01 & 20 & 16.8 & 1.16 \\
\hline & 10MAY1993 & 20 & 183.1 & 6.29 & 20 & 53.4 & 5.51 & 20 & 0.81 & 0.01 & 20 & 20.9 & 1.60 \\
\hline & 11MAY1993 & 20 & 170.7 & 3.95 & 20 & 48.0 & 3.30 & 20 & 0.94 & 0.01 & 20 & 20.6 & 1.15 \\
\hline & 12 MAY1993 & 20 & 173.1 & 5.86 & 20 & 50.0 & 6.16 & 20 & 0.91 & 0.01 & 20 & 20.0 & 1.66 \\
\hline & 13MAY1993 & 20 & 165.7 & 4.05 & 20 & 42.7 & 3.05 & 20 & 0.91 & 0.01 & 20 & 19.4 & 0.89 \\
\hline & 17MAY1993 & 20 & 167.3 & 4.50 & 20 & 45.7 & 4.37 & 20 & 0.93 & 0.01 & 20 & 18.1 & 1.25 \\
\hline & 18MAY1993 & 20 & 155.6 & 2.95 & 20 & 36.4 & 2.33 & 20 & 0.95 & 0.01 & 20 & 22.4 & 2.24 \\
\hline & 19MAY1993 & 20 & 164.0 & 4.16 & 20 & 41.5 & 2.89 & 20 & 0.92 & 0.01 & 20 & 22.6 & 1.52 \\
\hline & 20MAY1993 & 20 & 168.5 & 3.74 & 20 & 45.6 & 3.05 & 20 & 0.93 & 0.02 & 20 & 20.3 & 1.64 \\
\hline & 24MAY1993 & 20 & 163.5 & 4.16 & 20 & 38.6 & 3.21 & 20 & 0.85 & 0.01 & 20 & 21.7 & 1.48 \\
\hline & 25MAY1993 & 20 & 161.0 & 2.71 & 20 & 39.1 & 2.16 & 20 & 0.92 & 0.02 & 20 & 21.4 & 1.31 \\
\hline & 26MAY1993 & 20 & 168.2 & 3.79 & 20 & 45.2 & 2.96 & 20 & 0.93 & 0.02 & 20 & 22.1 & 1.34 \\
\hline & 27MAY1993 & 20 & 159.9 & 5.80 & 20 & 42.8 & 5.72 & 20 & 0.98 & 0.01 & 20 & 18.0 & 1.44 \\
\hline & 28MAY1993 & 20 & 150.8 & 2.72 & 20 & 35.3 & 1.73 & 20 & 1.02 & 0.02 & 20 & 20.9 & 1.56 \\
\hline & 29MAY1993 & 20 & 158.9 & 4.29 & 20 & 41.1 & 4.16 & 20 & 0.98 & 0.02 & 19 & 23.0 & 1.58 \\
\hline
\end{tabular}


Appendix G.1. Summary of selected data from hatchery sockeye salmon at Rock Island Dam (RIS) during spring 1993. Data includes sample size (N), mean (MEAN), and standard error (STDERR) of fork length in millimeters, wet weight in grams, condition factor (KFACTOR), and gill $\mathrm{Na}^{+}, \mathrm{K}^{+}$-ATPase activity (ATPase) in $\mu \mathrm{mol} \mathrm{P}_{\mathrm{i}} \cdot \mathrm{mg}_{\operatorname{protein}}{ }^{-1} \cdot \mathrm{h}^{-1}$.

\begin{tabular}{|c|c|c|c|c|c|c|c|c|c|c|c|c|c|}
\hline & & \multirow{2}{*}{\multicolumn{3}{|c|}{ FORK LENGTH }} & \multirow{2}{*}{\multicolumn{3}{|c|}{ WEIGHT }} & \multicolumn{3}{|c|}{ KFACTOR } & \multicolumn{3}{|c|}{ ATPase } \\
\hline & & & & & & & & \multirow[b]{2}{*}{$N$} & \multirow[b]{2}{*}{ MEAN } & \multirow{2}{*}{$\begin{array}{r}\text { STD - } \\
\text { ERR }\end{array}$} & \multirow[b]{2}{*}{$\mathrm{N}$} & \multirow[b]{2}{*}{ MEAN } & \multirow{2}{*}{$\begin{array}{r}\text { STD- } \\
\text { ERR }\end{array}$} \\
\hline & & $N$ & MEAN & STDERR & $N$ & MEAN & STDERR & & & & & & \\
\hline SITE & DATE & & & & & & & & & & & & \\
\hline \multirow[t]{16}{*}{ RIS } & 03 MAY1993 & 1 & 125.0 &. & 1 & 15.8 & . & 1 & 0.81 & . & 1 & 25.1 & . \\
\hline & 05 MAY1993 & 1 & 109.0 & . & 1 & 11.9 & . & 1 & 0.92 & . & 1 & 37.4 & . \\
\hline & 06MAY1993 & 1 & 126.0 & . & 1 & 16.5 & . & 1 & 0.83 & . & 1 & 28.5 & . \\
\hline & 10 MAY1993 & 1 & 120.0 & & 1 & 14.7 & . & 1 & 0.85 & . & 1 & 44.3 & . \\
\hline & 11 MAY1993 & 3 & 117.3 & 5.04 & 3 & 14.2 & 2.25 & 3 & 0.86 & 0.02 & 3 & 37.0 & 4.23 \\
\hline & 12 MAY1993 & 3 & 115.7 & 4.33 & 3 & 13.5 & 1.60 & 3 & 0.86 & 0.02 & 3 & 38.9 & 2.36 \\
\hline & 13 MAY1993 & 2 & 120.5 & 9.50 & 2 & 16.2 & 3.55 & 2 & 0.91 & 0.01 & 2 & 32.0 & 2.65 \\
\hline & 17 MAY1993 & 1 & 102.0 & & 1 & 9.4 & & 1 & 0.89 &. & 1 & 40.9 & . \\
\hline & $18 M A Y 1993$ & 3 & 115.3 & 5.36 & 3 & 14.8 & 1.91 & 3 & 0.95 & 0.02 & 3 & 38.0 & 2.01 \\
\hline & 19 MAY1993 & 6 & 116.7 & 3.02 & 6 & 14.9 & 1.02 & 6 & 0.93 & 0.02 & 6 & 39.3 & 3.97 \\
\hline & 20MAY1993 & 4 & 113.8 & 1.11 & 4 & 13.1 & 0.39 & 4 & 0.89 & 0.03 & 4 & 41.8 & 3.20 \\
\hline & 24MAY1993 & 1 & 131.0 & & 1 & 17.4 & & 1 & 0.77 & & 1 & 41.5 & \\
\hline & 26MAY1993 & 3 & 122.7 & 3.67 & 3 & 17.9 & 2.29 & 3 & 0.96 & 0.08 & 3 & 36.4 & 3.55 \\
\hline & 27MAY1993 & 10 & 121.0 & 2.21 & 10 & 16.4 & 0.90 & 10 & 0.92 & 0.02 & 10 & 35.4 & 1.56 \\
\hline & 28MAY1993 & 7 & 116.4 & 3.56 & 7 & 16.7 & 1.34 & 7 & 1.05 & 0.03 & 7 & 40.2 & 3.39 \\
\hline & $29 M A Y 1993$ & 1 & 122.0 & & 1 & 19.3 &. & 1 & 1.06 & . & 1 & 32.8 & . \\
\hline
\end{tabular}


Appendix G.2. Summary of selected data from wild sockeye salmon at Rock Island Dam (RIS) during spring 1993. Data includes sample size (N), mean (MEAN), and standard error (STDERR) of fork length in millimeters, wet weight in grams, condition factor (KFACTOR), and gill $\mathrm{Na}^{+}, \mathrm{K}^{+}$-ATPase activity (ATPase) in $\mu \mathrm{mol} \mathrm{P}_{\mathrm{i}} \cdot \mathrm{mg}_{\text {protein }}{ }^{-1} \cdot \mathrm{h}^{-1}$.

\begin{tabular}{|c|c|c|c|c|c|c|c|c|c|c|c|c|c|}
\hline & & \multirow{2}{*}{\multicolumn{3}{|c|}{ FORK LENGTH }} & \multirow{2}{*}{\multicolumn{3}{|c|}{ WEIGHT }} & \multicolumn{3}{|c|}{ KFACTOR } & \multicolumn{3}{|c|}{ ATPase } \\
\hline & & & & & & & & \multirow[b]{2}{*}{$\mathbf{N}$} & \multirow[b]{2}{*}{ MEAN } & \multirow{2}{*}{$\begin{array}{r}\text { STD - } \\
\text { ERR }\end{array}$} & \multirow[b]{2}{*}{$\mathrm{N}$} & \multirow[b]{2}{*}{ MEAN } & \multirow{2}{*}{$\begin{array}{r}\text { STD- } \\
\text { ERR }\end{array}$} \\
\hline & & $N$ & MEAN & STDERR & $\mathrm{N}$ & MEAN & STDERR & & & & & & \\
\hline SITE & DATE & & & & & & & & & & & & \\
\hline \multirow[t]{24}{*}{ RIS } & 20APR1993 & 10 & 85.6 & 1.09 & 10 & 5.5 & 0.20 & 10 & 0.88 & 0.02 & 9 & 21.1 & 2.17 \\
\hline & 21APR1993 & 10 & 85.6 & 1.41 & 10 & 5.3 & 0.21 & 10 & 0.84 & 0.01 & 10 & 21.1 & 2.19 \\
\hline & 22APR1993 & 10 & 87.2 & 2.10 & 10 & 5.6 & 0.42 & 10 & 0.83 & 0.02 & 10 & 23.1 & 2.64 \\
\hline & 26APR1993 & 10 & 85.2 & 1.31 & 10 & 5.5 & 0.24 & 10 & 0.88 & 0.01 & 10 & 21.7 & 2.12 \\
\hline & 27APR1993 & 10 & 81.3 & 1.65 & 10 & 4.8 & 0.21 & 10 & 0.89 & 0.02 & 10 & 20.4 & 2.24 \\
\hline & 28APR1993 & 10 & 85.4 & 1.49 & 10 & 5.4 & 0.23 & 10 & 0.86 & 0.02 & 10 & 22.3 & 2.64 \\
\hline & 29APR1993 & 10 & 89.3 & 4.56 & 10 & 7.0 & 1.49 & 10 & 0.90 & 0.02 & 10 & 24.0 & 1.35 \\
\hline & 03 MAY1993 & 10 & 83.0 & 1.94 & 10 & 5.2 & 0.28 & 10 & 0.91 & 0.02 & 10 & 24.1 & 2.86 \\
\hline & 04 MAY1993 & 10 & 84.9 & 1.36 & 10 & 5.1 & 0.24 & 10 & 0.84 & 0.02 & 10 & 25.3 & 2.92 \\
\hline & 05 MAY1993 & 10 & 83.6 & 1.83 & 10 & 5.0 & 0.26 & 10 & 0.86 & 0.02 & 10 & 22.4 & 2.39 \\
\hline & 06 MAY 1993 & 10 & 82.1 & 1.19 & 10 & 4.7 & 0.17 & 10 & 0.85 & 0.02 & 9 & 21.4 & 3.23 \\
\hline & 10MAY1993 & 10 & 94.1 & 4.26 & 10 & 6.8 & 1.23 & 10 & 0.76 & 0.02 & 10 & 39.7 & 3.61 \\
\hline & 11 MAY1993 & 10 & 86.9 & 1.56 & 10 & 5.6 & 0.22 & 10 & 0.86 & 0.02 & 10 & 40.5 & 2.21 \\
\hline & 12 MAY1993 & 10 & 87.4 & 4.77 & 10 & 7.4 & 2.03 & 10 & 0.97 & 0.04 & 10 & 34.5 & 2.59 \\
\hline & 13 MAY1993 & 10 & 103.4 & 5.55 & 10 & 11.8 & 1.90 & 10 & 0.96 & 0.03 & 10 & 40.5 & 2.41 \\
\hline & 17MAY1993 & 10 & 111.3 & 1.91 & 10 & 14.8 & 0.59 & 10 & 1.07 & 0.03 & 10 & 32.6 & 1.47 \\
\hline & 18 MAY1993 & 10 & 106.9 & 0.94 & 10 & 13.2 & 0.49 & 10 & 1.07 & 0.02 & 10 & 25.6 & 2.93 \\
\hline & 19MAY1993 & 10 & 104.4 & 2.09 & 10 & 12.8 & 0.52 & 10 & 1.13 & 0.05 & 10 & 28.4 & 1.70 \\
\hline & 20MAY1993 & 10 & 108.5 & 1.99 & 10 & 13.2 & 0.56 & 10 & 1.03 & 0.02 & 10 & 28.8 & 2.39 \\
\hline & 24MAY1993 & 10 & 109.5 & 3.07 & 10 & 12.2 & 0.97 & 10 & 0.90 & 0.02 & 10 & 27.4 & 1.76 \\
\hline & 25MAY1993 & 10 & 108.6 & 3.18 & 10 & 12.3 & 0.90 & 10 & 0.95 & 0.03 & 10 & 28.0 & 2.01 \\
\hline & 26 MAY1993 & 10 & 111.9 & 2.28 & 10 & 13.4 & 0.76 & 10 & 0.95 & 0.02 & 10 & 35.4 & 2.00 \\
\hline & 27MAY1993 & 10 & 106.5 & 1.34 & 10 & 12.6 & 0.45 & 10 & 1.05 & 0.03 & 10 & 33.2 & 1.17 \\
\hline & 28MAY1993 & 10 & 100.6 & 1.22 & 10 & 11.9 & 0.31 & 10 & 1.17 & 0.03 & 10 & 31.6 & 1.56 \\
\hline
\end{tabular}


Appendix H.1. Summary of selected data from yearling spring chinook salmon sampled at Dworshak NFH (DW), Entiat NFH (EN), Leavenworth NFH (LE), Lookingglass SFH (LO), Rapid River SFH (RA), Ringold SFH (RI), Sawtooth SFH (SA), and Winthrop NFH (WI) during spring 1994. Data includes sample size (N), mean (MEAN), and standard error (STDERR) of fork length in millimeters, wet weight in grams, condition factor (KFACTOR), and gill $\mathrm{Na}^{+}, \mathrm{K}^{+}$-ATPase activity (ATPase) in $\mu \mathrm{mol} \mathrm{P}_{\mathrm{i}} \cdot \mathrm{mg}$ protein ${ }^{-1} \cdot \mathrm{h}^{-1}$.

\begin{tabular}{|c|c|c|c|c|c|c|c|c|c|c|c|c|c|}
\hline & & \multirow{2}{*}{\multicolumn{3}{|c|}{ FORK LENGTH }} & \multirow{2}{*}{\multicolumn{3}{|c|}{ WEIGHT }} & \multicolumn{3}{|c|}{ KFACTOR } & \multicolumn{3}{|c|}{ ATPase } \\
\hline & & & & & & & & \multirow[b]{2}{*}{$N$} & \multirow[b]{2}{*}{ MEAN } & \multirow{2}{*}{$\begin{array}{l}\text { STD - } \\
\text { ERR }\end{array}$} & \multirow[b]{2}{*}{$N$} & \multirow[b]{2}{*}{ MEAN } & \multirow{2}{*}{$\begin{array}{r}\text { STD- } \\
\text { ERR }\end{array}$} \\
\hline & & $N$ & MEAN & STDERR & N & MEAN & STDERR & & & & & & \\
\hline SITE & DATE & & & & & & & & & & & & \\
\hline \multirow[t]{5}{*}{$\mathrm{DW}$} & 02 MAR1994 & 30 & 132.4 & 2.95 & 29 & 28.7 & 2.33 & 29 & 1.18 & 0.01 & 30 & 5.4 & 0.30 \\
\hline & 15MAR1994 & 60 & 127.3 & 1.08 & 60 & 25.0 & 0.65 & 60 & 1.20 & 0.01 & 59 & 8.6 & 0.26 \\
\hline & 31 MAR1994 & 90 & 131.7 & 1.09 & 90 & 27.2 & 0.74 & 90 & 1.17 & 0.01 & 88 & 8.6 & 0.18 \\
\hline & 21APR1994 & 60 & 135.5 & 1.32 & 60 & 29.2 & 1.00 & 60 & 1.15 & 0.01 & 56 & 9.1 & 0.31 \\
\hline & 03MAY1994 & 30 & 140.8 & 1.46 & 30 & 32.0 & 1.04 & 30 & 1.14 & 0.01 & 30 & 11.1 & 0.43 \\
\hline \multirow[t]{2}{*}{ EN } & 29MAR1994 & 60 & 139.3 & 1.52 & 60 & 31.4 & 1.05 & 60 & 1.14 & 0.01 & 28 & 9.9 & 0.50 \\
\hline & 11 MAY1994 & 30 & 99.5 & 1.22 & 30 & 11.4 & 0.45 & 30 & 1.14 & 0.02 & 30 & 16.2 & 0.83 \\
\hline LE & 19APR1994 & 60 & 128.9 & 1.61 & 60 & 25.9 & 1.03 & 60 & 1.18 & 0.01 & 30 & 8.4 & 0.44 \\
\hline LO & 30MAR1994 & 60 & 121.3 & 0.94 & 60 & 21.6 & 0.53 & 60 & 1.19 & 0.01 & 59 & 10.4 & 0.29 \\
\hline RA & 30MAR1994 & 59 & 124.5 & 0.97 & 60 & 21.8 & 0.56 & 59 & 1.11 & 0.01 & 29 & 8.8 & 0.30 \\
\hline RI & 28MAR1994 & 60 & 167.8 & 1.91 & 60 & 57.7 & 2.13 & 60 & 1.20 & 0.01 & 30 & 25.4 & 1.24 \\
\hline SA & 29MAR1994 & 60 & 118.3 & 0.95 & 60 & 18.0 & 0.53 & 60 & 1.07 & 0.01 & 29 & 10.3 & 0.49 \\
\hline$W I$ & 11APR1994 & 60 & 127.0 & 2.06 & 60 & 23.7 & 1.36 & 60 & 1.10 & 0.02 & 27 & 8.9 & 0.70 \\
\hline
\end{tabular}

Appendix H.2. Summary of selected data from subyearling chinook salmon sampled at Priest Rapids SFH (PR) in 1994. Data includes sample size (N), mean (MEAN), and standard error (STDERR) of fork length in millimeters, wet weight in grams, condition factor (KFACTOR), and gill $\mathrm{Na}^{+}, \mathrm{K}^{+}$-ATPase activity (ATPase) in $\mu \mathrm{mol} \mathrm{P}_{\mathrm{i}} \cdot \mathrm{mg} \operatorname{protein}^{-1} \cdot \mathrm{h}^{-1}$.

\begin{tabular}{|c|c|c|c|c|c|c|c|c|c|c|c|c|c|}
\hline & & \multirow{2}{*}{\multicolumn{3}{|c|}{ FORK LENGTH }} & \multirow{2}{*}{\multicolumn{3}{|c|}{ WEIGHT }} & \multicolumn{3}{|c|}{ KFACTOR } & \multicolumn{3}{|c|}{ ATPase } \\
\hline & & & & & & & & \multirow[b]{2}{*}{ N } & \multirow[b]{2}{*}{ MEAN } & \multirow{2}{*}{$\begin{array}{l}\text { STD- } \\
\text { ERR }\end{array}$} & \multirow[b]{2}{*}{$N$} & \multirow[b]{2}{*}{ MEAN } & \multirow{2}{*}{$\begin{array}{r}\text { STD- } \\
\text { ERR }\end{array}$} \\
\hline & & N & MEAN & STDERR & $\mathrm{N}$ & MEAN & STDERR & & & & & & \\
\hline SITE & DATE & & & & & & & & & & & & \\
\hline \multirow[t]{2}{*}{ PR } & 09JUN1994 & 90 & 96.9 & 0.71 & 90 & 9.8 & 0.25 & 90 & 1.06 & 0.01 & 89 & 5.9 & 0.25 \\
\hline & 15JUN1994 & 60 & 90.6 & 0.67 & 60 & 8.5 & 0.20 & 60 & 1.13 & 0.01 & 57 & 5.5 & 0.24 \\
\hline
\end{tabular}

Appendix H.3. Summary of selected data from and steelhead sampled at Dworshak NFH (DW) during spring 1994. Data includes sample size (N), mean (MEAN), and standard error (STDERR) of fork length in millimeters, wet weight in grams, condition factor (KFACTOR), and gill $\mathrm{Na}^{+}, \mathrm{K}^{+}$-ATPase activity (ATPase) in $\mu \mathrm{mol} \mathrm{P}_{\mathrm{i}} \cdot \mathrm{mg} \operatorname{protein}^{-1} \cdot \mathrm{h}^{-1}$.

\begin{tabular}{|c|c|c|c|c|c|c|c|c|c|c|c|c|c|}
\hline & & \multirow{2}{*}{\multicolumn{3}{|c|}{ FORK LENGTH }} & \multirow{2}{*}{\multicolumn{3}{|c|}{ WEIGHT }} & \multicolumn{3}{|c|}{ KFACTOR } & \multicolumn{3}{|c|}{ ATPase } \\
\hline & & & & & & & & \multirow[b]{2}{*}{ N } & \multirow[b]{2}{*}{ MEAN } & \multirow{2}{*}{$\begin{array}{l}\text { STD- } \\
\text { ERR }\end{array}$} & \multirow[b]{2}{*}{$\mathrm{N}$} & \multirow[b]{2}{*}{ MEAN } & \multirow{2}{*}{$\begin{array}{l}\text { STD- } \\
\text { ERR }\end{array}$} \\
\hline & & N & MEAN & STDERR & N & MEAN & STDERR & & & & & & \\
\hline SITE & DATE & & & & & & & & & & & & \\
\hline DW & 28APR1994 & 45 & 198.8 & 3.98 & 45 & 86.4 & 5.27 & 45 & 1.04 & 0.01 & 44 & 8.9 & 0.36 \\
\hline
\end{tabular}


Appendix H.4. Summary of selected data from summer chinook sampled at Wells SFH (WES) and McCall SFH (MC) during spring 1994. Data includes sample size (N), mean (MEAN), and standard error (STDERR) of fork length in millimeters, wet weight in grams, condition factor (KFACTOR), and gill $\mathrm{Na}^{+}, \mathrm{K}^{+}$-ATPase activity (ATPase) in $\mu \mathrm{mol} \mathrm{P}_{\mathrm{i}} \cdot \mathrm{mg}$ protein $^{-1} \cdot \mathrm{h}^{-1}$.

\begin{tabular}{|c|c|c|c|c|c|c|c|c|c|c|c|c|c|}
\hline & & \multirow{2}{*}{\multicolumn{3}{|c|}{ FORK LENGTH }} & \multirow{2}{*}{\multicolumn{3}{|c|}{ WEIGHT }} & \multicolumn{3}{|c|}{ KFACTOR } & \multicolumn{3}{|c|}{ ATPase } \\
\hline & & & & & & & & \multirow[b]{2}{*}{$\mathrm{N}$} & \multirow[b]{2}{*}{ MEAN } & \multirow{2}{*}{$\begin{array}{l}\text { STD- } \\
\text { ERR }\end{array}$} & \multirow[b]{2}{*}{$\mathrm{N}$} & \multirow[b]{2}{*}{ MEAN } & \multirow{2}{*}{$\begin{array}{c}\text { STD- } \\
\text { ERR }\end{array}$} \\
\hline & & N & MEAN & STDERR & N & MEAN & STDERR & & & & & & \\
\hline SITE & DATE & & & & & & & & & & & & \\
\hline \multirow[t]{2}{*}{ WES } & 12APR1994 & 30 & 146.3 & 2.61 & 30 & 36.3 & 1.91 & 30 & 1.12 & 0.01 & 28 & 9.4 & 0.53 \\
\hline & 14JUN1994 & 30 & 107.0 & 1.49 & 30 & 14.8 & 0.70 & 30 & 1.18 & 0.02 & 30 & 10.4 & 0.69 \\
\hline MC & 30MAR1994 & 60 & 114.9 & 1.05 & 60 & 18.3 & 0.52 & 60 & 1.19 & 0.01 & 30 & 11.2 & 0.36 \\
\hline
\end{tabular}


Appendix I.1. Summary of selected data from yearling hatchery spring/summer chinook salmon collected from the migration-at-large at the Clearwater River trap (CLW), Snake River Trap at Lewiston (LEW), Salmon River Trap (SRT), Imnaha River Trap (IMT), Grande Ronde River Trap (GRT), Lower Granite Dam (LGR), McNary Dam (MCN), and Rock Island Dam (RIS) during spring 1994. Data includes sample size (N), mean (MEAN), and standard error (STDERR) of fork length in millimeters, wet weight in grams, condition factor (KFACTOR), and gill $\mathrm{Na}^{+}, \mathrm{K}^{+}$-ATPase activity (ATPase) in $\mu \mathrm{mol} \mathrm{P}_{\mathrm{i}} \cdot \mathrm{mg}_{\text {protein }}{ }^{-1} \cdot \mathrm{h}^{-1}$.

\begin{tabular}{|c|c|c|c|c|c|c|c|c|c|c|c|c|c|}
\hline & & \multirow{2}{*}{\multicolumn{3}{|c|}{ FORK LENGTH }} & \multirow{2}{*}{\multicolumn{3}{|c|}{ WEIGHT }} & \multicolumn{3}{|c|}{ KFACTOR } & \multicolumn{3}{|c|}{ ATPase } \\
\hline & & & & & & & & \multirow[b]{2}{*}{ N } & \multirow[b]{2}{*}{ MEAN } & \multirow{2}{*}{$\begin{array}{l}\text { STD- } \\
\text { ERR }\end{array}$} & \multirow[b]{2}{*}{$\mathbf{N}$} & \multirow[b]{2}{*}{ MEAN } & \multirow{2}{*}{$\begin{array}{r}\text { STD- } \\
\text { ERR }\end{array}$} \\
\hline & & $\mathrm{N}$ & MEAN & STDERR & $\mathrm{N}$ & MEAN & STDERR & & & & & & \\
\hline SITE & DATE & & & & & & & & & & & & \\
\hline \multirow[t]{13}{*}{ CLW } & 08APR1994 & 1 & 97.0 & & 1 & 9.5 & & 1 & 1.04 & & 1 & 15.3 & \\
\hline & 11APR1994 & 21 & 133.4 & 2.93 & 21 & 25.7 & 1.34 & 21 & 1.07 & 0.03 & 21 & 9.5 & 0.52 \\
\hline & 13APR1994 & 25 & 134.4 & 1.83 & 25 & 25.6 & 1.08 & 25 & 1.04 & 0.02 & 23 & 11.2 & 0.58 \\
\hline & 15APR1994 & 30 & 134.0 & 2.02 & 30 & 27.4 & 1.38 & 30 & 1.11 & 0.01 & 30 & 11.3 & 0.50 \\
\hline & 18APR1994 & 19 & 139.8 & 3.30 & 19 & 30.6 & 2.87 & 19 & 1.08 & 0.01 & 20 & 12.1 & 1.21 \\
\hline & 20APR1994 & 30 & 121.8 & 1.69 & 30 & 22.2 & 1.03 & 30 & 1.21 & 0.02 & 24 & 8.0 & 0.35 \\
\hline & 22APR1994 & 20 & 127.5 & 2.86 & 20 & 22.5 & 1.96 & 20 & 1.05 & 0.02 & 20 & 11.4 & 1.26 \\
\hline & 27APR1994 & 21 & 130.5 & 3.54 & 21 & 26.4 & 1.87 & 21 & 1.15 & 0.03 & 19 & 9.7 & 0.69 \\
\hline & 29APR1994 & 20 & 130.4 & 3.29 & 20 & 23.9 & 1.68 & 20 & 1.05 & 0.02 & 18 & 10.3 & 0.90 \\
\hline & 02MAY1994 & 8 & 127.6 & 5.86 & 8 & 22.5 & 2.75 & 8 & 1.06 & 0.05 & 8 & 11.6 & 1.01 \\
\hline & 04MAY1994 & 13 & 133.1 & 2.58 & 13 & 24.2 & 1.68 & 13 & 1.01 & 0.02 & 13 & 12.1 & 0.74 \\
\hline & 06MAY1994 & 3 & 133.0 & 3.61 & 3 & 26.0 & 1.86 & 3 & 1.10 & 0.01 & 3 & 14.6 & 0.92 \\
\hline & 11MAY1994 & 24 & 137.2 & 2.56 & 24 & 28.0 & 1.62 & 24 & 1.06 & 0.02 & 22 & 11.6 & 0.77 \\
\hline \multirow[t]{19}{*}{ LEW } & 13APR1994 & 30 & 126.5 & 1.49 & 30 & 21.3 & 0.67 & 30 & 1.05 & 0.02 & 30 & 8.5 & 0.38 \\
\hline & 15APR1994 & 22 & 134.9 & 5.75 & 22 & 28.1 & 4.82 & 22 & 1.02 & 0.01 & 21 & 11.4 & 0.46 \\
\hline & 20APR1994 & 21 & 131.2 & 4.45 & 21 & 24.3 & 3.08 & 21 & 1.03 & 0.02 & 21 & 11.5 & 0.84 \\
\hline & 22APR1994 & 31 & 123.2 & 1.68 & 31 & 22.4 & 0.94 & 31 & 1.18 & 0.02 & 29 & 10.5 & 0.79 \\
\hline & 25APR1994 & 30 & 127.8 & 1.45 & 30 & 22.2 & 0.69 & 30 & 1.06 & 0.01 & 29 & 10.4 & 0.72 \\
\hline & 27APR1994 & 21 & 129.6 & 4.10 & 21 & 24.4 & 2.78 & 21 & 1.07 & 0.02 & 16 & 10.4 & 0.66 \\
\hline & 29APR1994 & 21 & 125.4 & 0.92 & 21 & 20.0 & 0.74 & 21 & 1.01 & 0.02 & 18 & 12.6 & 0.92 \\
\hline & 02MAY1994 & 21 & 127.2 & 1.90 & 21 & 21.8 & 0.88 & 21 & 1.05 & 0.02 & 20 & 16.0 & 0.87 \\
\hline & 04MAY1994 & 21 & 130.9 & 2.73 & 21 & 23.8 & 1.61 & 21 & 1.03 & 0.01 & 20 & 15.9 & 1.00 \\
\hline & 06MAY1994 & 21 & 125.4 & 1.77 & 21 & 21.1 & 0.89 & 21 & 1.06 & 0.01 & 19 & 17.7 & 0.92 \\
\hline & 09MAY1994 & 22 & 131.1 & 2.54 & 21 & 21.2 & 1.28 & 21 & 0.94 & 0.03 & 22 & 13.2 & 1.03 \\
\hline & 11 MAY1994 & 23 & 129.6 & 1.73 & 23 & 22.4 & 1.01 & 23 & 1.01 & 0.02 & 20 & 16.1 & 0.99 \\
\hline & 13MAY1994 & 22 & 122.0 & 1.81 & 22 & 19.3 & 0.98 & 22 & 1.05 & 0.01 & 21 & 14.1 & 1.06 \\
\hline & 16MAY1994 & 13 & 125.1 & 2.48 & 13 & 20.0 & 1.34 & 13 & 1.01 & 0.02 & 13 & 13.9 & 0.96 \\
\hline & 18MAY1994 & 7 & 133.9 & 5.55 & 7 & 25.1 & 3.41 & 7 & 1.01 & 0.02 & 7 & 14.4 & 1.49 \\
\hline & 19MAY1994 & 9 & 134.2 & 9.88 & 9 & 27.5 & 6.82 & 9 & 1.04 & 0.04 & 9 & 13.0 & 1.01 \\
\hline & 23MAY1994 & 2 & 131.0 & 4.00 & 2 & 24.8 & 3.50 & 2 & 1.10 & 0.06 & 2 & 13.6 & 0.43 \\
\hline & 25MAY1994 & 2 & 119.5 & 7.50 & 2 & 18.8 & 3.50 & 2 & 1.09 & 0.00 & 2 & 16.2 & 3.08 \\
\hline & 27MAY1994 & 1 & 139.0 & & 1 & 29.8 & & 1 & 1.11 & & 1 & 24.8 & \\
\hline \multirow[t]{14}{*}{ SRT } & 12APR1994 & 40 & 127.3 & 1.15 & 40 & 21.5 & 0.60 & 40 & 1.03 & 0.01 & 39 & 8.1 & 0.31 \\
\hline & 14APR1994 & 50 & 131.2 & 1.01 & 50 & 22.9 & 0.47 & 50 & 1.01 & 0.01 & 50 & 9.2 & 0.44 \\
\hline & 19APR1994 & 40 & 133.0 & 1.19 & 40 & 22.7 & 0.60 & 40 & 0.96 & 0.01 & 37 & 10.1 & 0.86 \\
\hline & 21APR1994 & 50 & 123.4 & 1.17 & 50 & 18.7 & 0.44 & 50 & 0.99 & 0.01 & 42 & 10.0 & 0.69 \\
\hline & 26APR1994 & 40 & 121.3 & 1.03 & 40 & 18.7 & 0.47 & 40 & 1.04 & 0.01 & 40 & 11.5 & 0.46 \\
\hline & 28APR1994 & 50 & 120.1 & 1.09 & 50 & 18.6 & 0.51 & 50 & 1.07 & 0.01 & 47 & 12.2 & 0.53 \\
\hline & 03MAY1994 & 40 & 127.0 & 1.10 & 40 & 20.4 & 0.49 & 40 & 0.99 & 0.01 & 39 & 12.7 & 0.54 \\
\hline & 05MAY1994 & 51 & 125.7 & 1.35 & 51 & 21.1 & 0.69 & 51 & 1.05 & 0.01 & 51 & 14.6 & 0.57 \\
\hline & 10MAY1994 & 40 & 121.7 & 1.54 & 40 & 18.8 & 0.73 & 40 & 1.02 & 0.01 & 39 & 13.2 & 0.77 \\
\hline & 12MAY1994 & 37 & 121.2 & 1.41 & 37 & 18.6 & 0.71 & 37 & 1.03 & 0.01 & 35 & 13.5 & 0.75 \\
\hline & 17MAY1994 & 5 & 122.2 & 2.27 & 5 & 17.9 & 1.36 & 5 & 0.98 & 0.04 & 5 & 12.5 & 1.04 \\
\hline & 19MAY1994 & 11 & 118.8 & 3.35 & 11 & 18.2 & 1.27 & 11 & 1.07 & 0.03 & 11 & 14.7 & 1.14 \\
\hline & 24MAY1994 & 21 & 131.2 & 1.79 & 21 & 21.7 & 0.95 & 21 & 0.95 & 0.02 & 21 & 15.6 & 1.01 \\
\hline & 26MAY1994 & 40 & 126.8 & 1.38 & 40 & 19.1 & 0.75 & 40 & 0.92 & 0.01 & 40 & 15.9 & 0.61 \\
\hline
\end{tabular}


Appendix I.1 (continued)

\begin{tabular}{|c|c|c|c|c|c|c|c|c|c|c|c|c|c|}
\hline & & \multirow{2}{*}{\multicolumn{3}{|c|}{ FORK LENGTH }} & \multirow{2}{*}{\multicolumn{3}{|c|}{ WEIGHT }} & \multicolumn{3}{|c|}{ KFACTOR } & \multicolumn{3}{|c|}{ ATPase } \\
\hline & & & & & & & & \multirow[b]{2}{*}{$N$} & \multirow[b]{2}{*}{ MEAN } & \multirow{2}{*}{$\begin{array}{r}\text { STD- } \\
\text { ERR }\end{array}$} & \multirow[b]{2}{*}{$N$} & \multirow[b]{2}{*}{ MEAN } & \multirow{2}{*}{$\begin{array}{r}\text { STD- } \\
\text { ERR }\end{array}$} \\
\hline & & N & MEAN & STDERR & $N$ & MEAN & STDERR & & & & & & \\
\hline SITE & DATE & & & & & & & & & & & & \\
\hline \multirow[t]{3}{*}{ GRT } & 19APR1994 & 5 & 118.8 & 8.06 & 5 & 18.5 & 4.64 & 5 & 1.04 & 0.11 & 5 & 10.4 & 1.44 \\
\hline & 28APR1994 & 1 & 125.0 & & 1 & 22.7 & . & 1 & 1.16 & . & 1 & 16.4 & . \\
\hline & 10MAY1994 & 16 & 133.2 & 1.20 & 16 & 25.5 & 0.77 & 16 & 1.07 & 0.01 & 15 & 11.5 & 0.70 \\
\hline \multirow[t]{7}{*}{ IMT } & 13APR1994 & 40 & 130.8 & 1.76 & 40 & 24.9 & 1.05 & 40 & 1.09 & 0.01 & 39 & 9.8 & 0.36 \\
\hline & 14APR1994 & 40 & 128.8 & 1.11 & 40 & 21.7 & 0.52 & 40 & 1.01 & 0.01 & 38 & 10.8 & 0.39 \\
\hline & 15APR1994 & 40 & 131.3 & 1.58 & 40 & 23.3 & 0.93 & 40 & 1.01 & 0.01 & 37 & 10.4 & 0.32 \\
\hline & 26APR1994 & 41 & 123.8 & 1.33 & 41 & 21.1 & 0.75 & 41 & 1.10 & 0.01 & 41 & 9.0 & 0.31 \\
\hline & 28APR1994 & 34 & 123.5 & 1.56 & 34 & 21.7 & 0.83 & 34 & 1.13 & 0.01 & 32 & 9.9 & 0.49 \\
\hline & 03MAY1994 & 36 & 125.2 & 1.65 & 36 & 20.8 & 0.84 & 36 & 1.05 & 0.02 & 34 & 12.4 & 0.73 \\
\hline & 04MAY1994 & 44 & 124.0 & 1.35 & 44 & 22.2 & 0.79 & 44 & 1.15 & 0.03 & 43 & 13.3 & 0.54 \\
\hline \multirow[t]{13}{*}{ LGR } & 20APR1994 & 28 & 140.3 & 2.29 & 0 & &. & 0 & & . & 28 & 16.5 & 0.77 \\
\hline & 22APR1994 & 21 & 143.0 & 1.52 & 21 & 29.1 & 0.97 & 21 & 0.99 & 0.02 & 20 & 20.1 & 1.26 \\
\hline & 25APR1994 & 20 & 129.4 & 1.25 & 20 & 24.1 & 0.81 & 20 & 1.11 & 0.02 & 20 & 17.7 & 0.71 \\
\hline & 27APR1994 & 30 & 131.9 & 2.01 & 0 & & & 0 & . &. & 30 & 17.3 & 0.81 \\
\hline & 29APR1994 & 20 & 136.9 & 2.23 & 20 & 23.7 & 1.03 & 20 & 0.91 & 0.01 & 20 & 20.1 & 0.96 \\
\hline & 06MAY1994 & 67 & 140.6 & 1.42 & 67 & 25.0 & 1.19 & 67 & 0.88 & 0.01 & 67 & 20.7 & 0.68 \\
\hline & 09MAY1994 & 31 & 142.2 & 2.65 & 31 & 27.4 & 1.91 & 31 & 0.92 & 0.01 & 27 & 17.9 & 0.81 \\
\hline & 11MAY1994 & 36 & 143.8 & 1.73 & 10 & 30.7 & 2.61 & 10 & 0.96 & 0.02 & 37 & 22.0 & 0.99 \\
\hline & 13MAY1994 & 19 & 137.3 & 2.44 & 19 & 25.9 & 1.48 & 19 & 0.99 & 0.01 & 15 & 18.6 & 1.18 \\
\hline & 16MAY1994 & 30 & 140.3 & 1.56 & 30 & 27.0 & 1.12 & 30 & 0.97 & 0.01 & 30 & 19.8 & 1.37 \\
\hline & 18MAY1994 & 33 & 141.4 & 1.72 & 33 & 27.7 & 1.02 & 33 & 0.97 & 0.01 & 33 & 19.9 & 1.13 \\
\hline & 20MAY1994 & 41 & 140.4 & 1.66 & 41 & 26.7 & 0.99 & 41 & 0.95 & 0.01 & 41 & 20.9 & 1.13 \\
\hline & 23MAY1994 & 1 & 167.0 & & 1 & 45.0 & & 1 & 0.97 & & 1 & 11.9 & . \\
\hline \multirow[t]{6}{*}{ MCN } & 26APR1994 & 14 & 172.1 & 12.21 & 14 & 64.6 & 18.80 & 14 & 0.99 & 0.02 & 14 & 20.4 & 1.77 \\
\hline & 03MAY1994 & 6 & 165.2 & 4.81 & 6 & 44.9 & 4.31 & 6 & 0.98 & 0.02 & 6 & 16.3 & 1.45 \\
\hline & 10MAY1994 & 5 & 143.8 & 4.85 & 5 & 28.5 & 3.24 & 5 & 0.94 & 0.02 & 5 & 18.9 & 1.95 \\
\hline & 17MAY1994 & 16 & 152.0 & 5.48 & 16 & 34.5 & 4.39 & 16 & 0.92 & 0.01 & 16 & 16.5 & 1.42 \\
\hline & 24MAY1994 & 10 & 146.2 & 6.04 & 10 & 30.7 & 4.88 & 10 & 0.92 & 0.01 & 10 & 26.1 & 1.52 \\
\hline & 01JUN1994 & 16 & 165.9 & 4.75 & 16 & 46.0 & 3.77 & 16 & 0.97 & 0.02 & 16 & 26.2 & 2.06 \\
\hline \multirow[t]{18}{*}{ RIS } & 21APR1994 & 10 & 143.7 & 3.57 & 0 & . & . & 0 & . &. & 10 & 15.5 & 1.40 \\
\hline & 25APR1994 & 10 & 136.6 & 9.36 & 10 & 25.9 & 4.80 & 10 & 0.89 & 0.03 & 10 & 11.0 & 1.70 \\
\hline & 27APR1994 & 8 & 135.0 & 4.94 & 8 & 22.1 & 2.12 & 8 & 0.88 & 0.04 & 7 & 10.2 & 1.25 \\
\hline & 28APR1994 & 1 & 191.0 & & 1 & 61.8 & . & 1 & 0.89 & $\cdot$ & 1 & 21.5 & . \\
\hline & 02MAY1994 & 9 & 149.0 & 5.54 & 0 & . &. & 0 & . & . & 9 & 14.2 & 1.11 \\
\hline & 03MAY1994 & 13 & 151.4 & 6.63 & 13 & 35.6 & 4.88 & 13 & 0.96 & 0.02 & 13 & 11.7 & 1.14 \\
\hline & 04MAY1994 & 10 & 156.5 & 7.97 & 10 & 38.7 & 5.26 & 10 & 0.95 & 0.02 & 10 & 13.6 & 1.03 \\
\hline & 05MAY1994 & 14 & 149.6 & 4.23 & 14 & 33.5 & 2.61 & 14 & 0.98 & 0.01 & 13 & 15.4 & 1.30 \\
\hline & 09MAY1994 & 12 & 147.0 & 5.41 & 12 & 31.4 & 3.57 & 12 & 0.94 & 0.01 & 11 & 18.3 & 2.00 \\
\hline & 10MAY1994 & 10 & 152.1 & 5.10 & 10 & 32.5 & 3.38 & 10 & 0.91 & 0.04 & 10 & 14.5 & 1.92 \\
\hline & 12 MAY1994 & 11 & 146.8 & 4.69 & 11 & 29.8 & 3.70 & 11 & 0.90 & 0.02 & 11 & 11.9 & 1.73 \\
\hline & 16MAY1994 & 10 & 142.6 & 9.71 & 10 & 30.9 & 5.95 & 10 & 0.95 & 0.02 & 10 & 17.2 & 1.42 \\
\hline & 17MAY1994 & 15 & 144.1 & 4.10 & 15 & 29.8 & 2.85 & 15 & 0.96 & 0.01 & 11 & 17.4 & 2.02 \\
\hline & 18MAY1994 & 15 & 164.1 & 5.00 & 15 & 43.4 & 4.23 & 15 & 0.94 & 0.02 & 9 & 14.9 & 1.68 \\
\hline & 23MAY1994 & 16 & 162.4 & 4.45 & 16 & 42.1 & 3.44 & 16 & 0.95 & 0.01 & 16 & 20.2 & 1.52 \\
\hline & 24MAY1994 & 17 & 164.9 & 4.23 & 17 & 44.0 & 3.20 & 17 & 0.95 & 0.01 & 17 & 23.5 & 2.21 \\
\hline & 25MAY1994 & 16 & 158.3 & 2.81 & 13 & 40.3 & 2.52 & 13 & 0.96 & 0.02 & 16 & 20.0 & 1.51 \\
\hline & 26MAY1994 & 21 & 159.0 & 4.18 & 21 & 41.6 & 3.22 & 21 & 0.99 & 0.01 & 20 & 21.0 & 1.77 \\
\hline
\end{tabular}


Appendix I.2. Summary of selected data from non-adipose fin clipped yearling spring/summer chinook salmon collected from the migration-at-large at McNary Dam (MCN) and Rock Island Dam (RIS) during spring 1994. Data includes sample size (N), mean (MEAN), and standard error (STDERR) of fork length in millimeters, wet weight in grams, condition factor (KFACTOR), and gill $\mathrm{Na}^{+}, \mathrm{K}^{+}$-ATPase activity (ATPase) in $\mu \mathrm{mol} \mathrm{P}_{\mathrm{i}} \cdot \mathrm{mg} \mathrm{protein}^{-1} \cdot \mathrm{h}^{-1}$.

\begin{tabular}{|c|c|c|c|c|c|c|c|c|c|c|c|c|c|}
\hline & & \multirow{2}{*}{\multicolumn{3}{|c|}{ FORK LENGTH }} & \multirow{2}{*}{\multicolumn{3}{|c|}{ WEIGHT }} & \multicolumn{3}{|c|}{ KFACTOR } & \multicolumn{3}{|c|}{ ATPase } \\
\hline & & & & & & & & \multirow[b]{2}{*}{$N$} & \multirow[b]{2}{*}{ MEAN } & \multirow{2}{*}{$\begin{array}{r}\text { STD- } \\
\text { ERR }\end{array}$} & \multirow[b]{2}{*}{$N$} & \multirow[b]{2}{*}{ MEAN } & \multirow{2}{*}{$\begin{array}{r}\text { STD - } \\
\text { ERR }\end{array}$} \\
\hline & & $N$ & MEAN & STDERR & $\mathrm{N}$ & MEAN & STDERR & & & & & & \\
\hline SITE & DATE & & & & & & & & & & & & \\
\hline \multirow[t]{5}{*}{ MCN } & 03MAY1994 & 15 & 154.5 & 5.87 & 15 & 38.5 & 4.07 & 15 & 0.98 & 0.02 & 15 & 15.7 & 0.80 \\
\hline & 10MAY1994 & 16 & 145.0 & 3.66 & 16 & 29.5 & 2.12 & 16 & 0.94 & 0.02 & 14 & 17.7 & 1.25 \\
\hline & 17MAY1994 & 4 & 180.0 & 14.67 & 4 & 57.9 & 12.75 & 4 & 0.94 & 0.01 & 4 & 14.7 & 3.20 \\
\hline & 24MAY1994 & 10 & 139.4 & 4.04 & 10 & 25.4 & 1.93 & 10 & 0.92 & 0.02 & 10 & 24.9 & 0.81 \\
\hline & 01JUN1994 & 4 & 164.3 & 6.18 & 4 & 41.5 & 5.32 & 4 & 0.92 & 0.06 & 4 & 18.9 & 2.64 \\
\hline \multirow[t]{20}{*}{ RIS } & 21APR1994 & 14 & 125.9 & 7.53 & 0 & $\cdot$ & $\cdot$ & 0 & . & $\cdot$ & 13 & 16.4 & 1.90 \\
\hline & 25APR1994 & 24 & 129.1 & 4.35 & 22 & 20.3 & 2.24 & 22 & 0.93 & 0.02 & 24 & 14.9 & 1.08 \\
\hline & 26APR1994 & 26 & 138.2 & 4.41 & 26 & 27.4 & 2.81 & 26 & 0.96 & 0.01 & 26 & 12.3 & 0.84 \\
\hline & 27APR1994 & 17 & 145.6 & 4.93 & 17 & 28.4 & 2.95 & 17 & 0.87 & 0.02 & 17 & 12.6 & 1.09 \\
\hline & 28APR1994 & 22 & 134.7 & 4.66 & 22 & 23.5 & 2.56 & 22 & 0.89 & 0.01 & 24 & 13.6 & 0.74 \\
\hline & 02 MAY1994 & 17 & 137.1 & 5.49 & 0 & & & 0 & & & 14 & 15.2 & 0.66 \\
\hline & 03MAY1994 & 12 & 131.9 & 4.67 & 12 & 22.6 & 2.12 & 12 & 0.95 & 0.01 & 10 & 15.1 & 1.14 \\
\hline & 04MAY1994 & 14 & 130.1 & 3.68 & 14 & 22.2 & 1.60 & 14 & 0.98 & 0.01 & 14 & 14.4 & 0.85 \\
\hline & 05MAY1994 & 12 & 138.0 & 5.17 & 12 & 27.1 & 2.93 & 12 & 0.99 & 0.01 & 11 & 15.8 & 1.82 \\
\hline & 09MAY1994 & 15 & 140.1 & 4.99 & 15 & 27.1 & 3.49 & 15 & 0.93 & 0.02 & 15 & 21.0 & 1.40 \\
\hline & 10MAY1994 & 14 & 135.1 & 3.72 & 13 & 23.7 & 1.69 & 13 & 0.94 & 0.02 & 14 & 15.9 & 1.13 \\
\hline & 11MAY1994 & 1 & 139.0 & & 0 & & . & 0 & $\cdot$ & $\cdot$ & 1 & 5.7 & . \\
\hline & 12MAY1994 & 13 & 138.8 & 3.23 & 13 & 24.2 & 1.49 & 13 & 0.89 & 0.01 & 13 & 14.8 & 1.04 \\
\hline & 16MAY1994 & 15 & 135.7 & 4.82 & 15 & 24.4 & 2.36 & 15 & 0.95 & 0.02 & 15 & 20.2 & 0.89 \\
\hline & 17MAY1994 & 11 & 134.7 & 1.74 & 11 & 22.8 & 0.97 & 11 & 0.93 & 0.01 & 7 & 17.2 & 2.02 \\
\hline & 18MAY1994 & 10 & 144.0 & 6.64 & 10 & 29.3 & 4.34 & 10 & 0.93 & 0.01 & 7 & 19.3 & 1.45 \\
\hline & 23MAY1994 & 9 & 153.2 & 7.29 & 9 & 35.8 & 5.06 & 9 & 0.94 & 0.02 & 9 & 22.0 & 1.59 \\
\hline & 24MAY1994 & 8 & 156.4 & 3.68 & 8 & 35.2 & 2.34 & 8 & 0.91 & 0.01 & 8 & 22.4 & 3.12 \\
\hline & 25MAY1994 & 9 & 160.6 & 6.19 & 9 & 40.0 & 3.74 & 9 & 0.95 & 0.02 & 9 & 23.4 & 2.42 \\
\hline & 26MAY1994 & 4 & 160.5 & 7.24 & 4 & 40.3 & 4.79 & 4 & 0.96 & 0.02 & 4 & 27.3 & 4.48 \\
\hline
\end{tabular}


Appendix J. Summary of selected data from yearling wild spring/summer chinook salmon collected from the migration-at-large at the Clearwater River Trap (CLW), Snake River Trap at Lewiston (LEW), Salmon River Trap (SRT), Imnaha River Trap (IMT), Grande Ronde River Trap (GRT), and Lower Granite Dam (LGR) during spring 1994. Data includes sample size (N), mean (MEAN), and standard error (STDERR) of fork length in millimeters, wet weight in grams, condition factor (KFACTOR), and gill $\mathrm{Na}^{+}, \mathrm{K}^{+}$-ATPase activity (ATPase) in $\mu \mathrm{mol} \mathrm{P}_{\mathrm{i}} \cdot \mathrm{mg} \mathrm{protein}^{-1} \cdot \mathrm{h}^{-1}$.

\begin{tabular}{|c|c|c|c|c|c|c|c|c|c|c|c|c|c|}
\hline & & \multirow{2}{*}{\multicolumn{3}{|c|}{ FORK LENGTH }} & \multirow{2}{*}{\multicolumn{3}{|c|}{ WEIGHT }} & \multicolumn{3}{|c|}{ KFACTOR } & \multicolumn{3}{|c|}{ ATPase } \\
\hline & & & & & & & & \multirow[b]{2}{*}{ N } & \multirow[b]{2}{*}{ MEAN } & \multirow{2}{*}{$\begin{array}{r}\text { STD- } \\
\text { ERR }\end{array}$} & \multirow[b]{2}{*}{ N } & \multirow[b]{2}{*}{ MEAN } & \multirow{2}{*}{$\begin{array}{r}\text { STD- } \\
\text { ERR }\end{array}$} \\
\hline & & N & MEAN & STDERR & N & MEAN & STDERR & & & & & & \\
\hline SITE & DATE & & & & & & & & & & & & \\
\hline \multirow{13}{*}{ CLW } & 08APR1994 & 5 & 112.6 & 4.76 & 5 & 14.3 & 1.60 & 5 & 0.99 & 0.06 & 5 & 18.7 & 0.97 \\
\hline & 11APR1994 & 18 & 109.4 & 3.02 & 17 & 12.3 & 0.79 & 17 & 0.96 & 0.03 & 18 & 14.1 & 0.84 \\
\hline & 13APR1994 & 6 & 115.0 & 4.96 & 6 & 15.9 & 1.95 & 6 & 1.02 & 0.03 & 6 & 14.1 & 2.24 \\
\hline & 15APR1994 & 9 & 106.2 & 3.55 & 9 & 13.1 & 1.33 & 9 & 1.06 & 0.02 & 9 & 14.9 & 1.35 \\
\hline & 18APR1994 & 5 & 107.2 & 1.11 & 5 & 13.7 & 0.84 & 5 & 1.11 & 0.05 & 5 & 17.7 & 4.63 \\
\hline & 20APR1994 & 30 & 102.4 & 1.55 & 30 & 11.7 & 0.50 & 30 & 1.08 & 0.02 & 28 & 13.4 & 1.69 \\
\hline & 22APR1994 & 20 & 104.7 & 2.22 & 20 & 12.1 & 0.96 & 20 & 1.03 & 0.05 & 20 & 11.4 & 0.96 \\
\hline & 27APR1994 & 7 & 99.0 & 2.37 & 7 & 11.0 & 0.79 & 7 & 1.13 & 0.03 & 7 & 10.6 & 1.00 \\
\hline & 29APR1994 & 8 & 106.3 & 6.05 & 8 & 13.6 & 2.25 & 8 & 1.08 & 0.02 & 7 & 12.5 & 1.12 \\
\hline & 02MAY1994 & 3 & 107.7 & 16.48 & 3 & 17.0 & 7.22 & 3 & 1.23 & 0.05 & 2 & 17.3 & 1.99 \\
\hline & 04 MAY1994 & 3 & 99.7 & 2.96 & 3 & 9.2 & 1.19 & 3 & 0.92 & 0.05 & 3 & 14.7 & 3.32 \\
\hline & 06 MAY 1994 & 2 & 107.5 & 0.50 & 2 & 15.7 & 0.65 & 2 & 1.26 & 0.03 & 2 & 21.0 & 2.03 \\
\hline & 11 MAY1994 & 10 & 107.7 & 4.89 & 10 & 15.2 & 2.70 & 10 & 1.14 & 0.02 & 8 & 13.0 & 1.78 \\
\hline \multirow[t]{19}{*}{ LEW } & 13APR1994 & 4 & 103.8 & 6.74 & 4 & 12.1 & 2.08 & 4 & 1.04 & 0.01 & 4 & 11.5 & 0.88 \\
\hline & 15APR1994 & 3 & 110.7 & 4.84 & 3 & 13.5 & 1.55 & 3 & 0.99 & 0.03 & 3 & 19.4 & 2.97 \\
\hline & 20APR1994 & 20 & 110.7 & 2.14 & 20 & 13.6 & 0.63 & 20 & 1.00 & 0.02 & 17 & 13.4 & 2.16 \\
\hline & 22APR1994 & 29 & 110.5 & 2.32 & 27 & 16.1 & 1.37 & 27 & 1.15 & 0.01 & 27 & 15.8 & 1.15 \\
\hline & 25APR 1994 & 27 & 105.0 & 1.52 & 27 & 12.7 & 0.56 & 27 & 1.08 & 0.02 & 20 & 14.3 & 0.92 \\
\hline & 27APR1994 & 19 & 104.7 & 1.59 & 19 & 12.8 & 0.59 & 19 & 1.11 & 0.02 & 17 & 14.5 & 1.41 \\
\hline & 29APR1994 & 11 & 106.2 & 3.30 & 11 & 13.2 & 1.21 & 11 & 1.08 & 0.02 & 11 & 13.6 & 0.95 \\
\hline & $02 M A Y 1994$ & 4 & 103.8 & 1.93 & 4 & 10.9 & 0.51 & 4 & 0.97 & 0.05 & 4 & 11.2 & 2.44 \\
\hline & 04 MAY1994 & 6 & 111.0 & 3.13 & 6 & 14.1 & 1.25 & 6 & 1.02 & 0.02 & 5 & 22.1 & 1.86 \\
\hline & 06 MAY1994 & 6 & 106.0 & 2.02 & 6 & 13.4 & 0.99 & 6 & 1.11 & 0.03 & 6 & 17.9 & 2.22 \\
\hline & $09 M A Y 1994$ & 18 & 106.8 & 1.69 & 17 & 12.2 & 0.51 & 17 & 1.02 & 0.04 & 18 & 14.6 & 1.32 \\
\hline & 11 MAY1994 & 18 & 109.0 & 1.57 & 18 & 13.1 & 0.56 & 18 & 1.01 & 0.02 & 18 & 13.1 & 1.16 \\
\hline & $13 M A Y 1994$ & 17 & 103.6 & 1.25 & 16 & 12.6 & 0.46 & 16 & 1.10 & 0.02 & 16 & 15.9 & 1.22 \\
\hline & 16MAY1994 & 2 & 106.0 & 0.00 & 2 & 13.2 & 0.30 & 2 & 1.11 & 0.03 & 2 & 10.6 & 2.56 \\
\hline & $18 M A Y 1994$ & 9 & 111.4 & 2.56 & 9 & 14.5 & 1.01 & 9 & 1.04 & 0.03 & 9 & 14.8 & 1.00 \\
\hline & 19MAY1994 & 2 & 118.0 & 9.00 & 2 & 18.6 & 4.15 & 2 & 1.11 & 0.00 & 2 & 18.3 & 1.97 \\
\hline & 23MAY1994 & 1 & 111.0 & & 1 & 14.6 & & 1 & 1.07 & & 1 & 19.9 & \\
\hline & 25MAY1994 & 8 & 134.6 & 23.89 & 8 & 16.0 & 2.76 & 8 & 1.01 & 0.14 & 8 & 21.4 & 1.78 \\
\hline & 27 MAY1994 & 7 & 105.3 & 2.87 & 7 & 13.0 & 1.10 & 7 & 1.10 & 0.05 & 7 & 18.0 & 1.96 \\
\hline \multirow[t]{15}{*}{ SRT } & 05APR1994 & 40 & 111.2 & 1.58 & 0 & & & 0 & & & 39 & 16.9 & 0.71 \\
\hline & 06APR1994 & 31 & 109.8 & 1.73 & 31 & 14.5 & 0.71 & 31 & 1.07 & 0.01 & 38 & 14.7 & 0.70 \\
\hline & 07APR1994 & 40 & 112.4 & 1.32 & 40 & 15.8 & 0.55 & 40 & 1.10 & 0.02 & 40 & 15.3 & 0.60 \\
\hline & 12APR1994 & 38 & 104.7 & 1.24 & 38 & 12.7 & 0.44 & 38 & 1.09 & 0.01 & 38 & 13.9 & 0.67 \\
\hline & 14APR1994 & 40 & 106.4 & 1.30 & 40 & 12.8 & 0.56 & 40 & 1.05 & 0.01 & 39 & 15.9 & 0.87 \\
\hline & 19APR1994 & 40 & 107.8 & 1.46 & 40 & 13.1 & 0.55 & 40 & 1.03 & 0.01 & 36 & 15.2 & 1.22 \\
\hline & 21APR1994 & 40 & 105.6 & 1.59 & 40 & 12.1 & 0.67 & 40 & 1.01 & 0.03 & 38 & 15.4 & 1.32 \\
\hline & 26APR1994 & 33 & 100.3 & 1.21 & 33 & 11.0 & 0.40 & 33 & 1.08 & 0.01 & 30 & 13.8 & 1.02 \\
\hline & 28APR1994 & 40 & 100.9 & 0.95 & 40 & 11.3 & 0.33 & 40 & 1.09 & 0.01 & 39 & 13.8 & 0.86 \\
\hline & 03MAY1994 & 18 & 105.6 & 2.46 & 18 & 12.8 & 0.89 & 18 & 1.06 & 0.02 & 18 & 14.8 & 0.94 \\
\hline & 05 MAY 1994 & 39 & 105.7 & 1.07 & 39 & 13.2 & 0.40 & 39 & 1.11 & 0.01 & 38 & 16.4 & 0.71 \\
\hline & $10 M A Y 1994$ & 40 & 102.4 & 1.63 & 40 & 12.0 & 0.58 & 40 & 1.08 & 0.01 & 39 & 14.4 & 0.91 \\
\hline & $12 M A Y 1994$ & 20 & 98.4 & 1.80 & 20 & 10.5 & 0.66 & 20 & 1.08 & 0.02 & 19 & 12.0 & 1.01 \\
\hline & 17MAY1994 & 7 & 103.4 & 1.72 & 7 & 11.2 & 0.55 & 7 & 1.01 & 0.03 & 7 & 13.2 & 1.35 \\
\hline & 19MAY1994 & 4 & 105.0 & 3.89 & 4 & 13.8 & 1.75 & 4 & 1.18 & 0.06 & 4 & 18.2 & 3.04 \\
\hline
\end{tabular}


Appendix J (continued)

\begin{tabular}{|c|c|c|c|c|c|c|c|c|c|c|c|c|c|}
\hline & & \multirow{2}{*}{\multicolumn{3}{|c|}{ FORK LENGTH }} & \multirow{2}{*}{\multicolumn{3}{|c|}{ WEIGHT }} & \multicolumn{3}{|c|}{ KFACTOR } & \multicolumn{3}{|c|}{ ATPase } \\
\hline & & & & & & & & \multirow[b]{2}{*}{$N$} & \multirow[b]{2}{*}{ MEAN } & \multirow{2}{*}{$\begin{array}{r}\text { STD - } \\
\text { ERR }\end{array}$} & \multirow[b]{2}{*}{$N$} & \multirow[b]{2}{*}{ MEAN } & \multirow{2}{*}{$\begin{array}{r}\text { STD- } \\
\text { ERR }\end{array}$} \\
\hline & & N & MEAN & STDERR & N & MEAN & STDERR & & & & & & \\
\hline SITE & DATE & & & & & & & & & & & & \\
\hline \multirow[t]{2}{*}{ SRT } & 24MAY1994 & 17 & 111.2 & 2.32 & 17 & 14.9 & 0.95 & 17 & 1.06 & 0.03 & 17 & 17.6 & 1.33 \\
\hline & 26MAY1994 & 20 & 112.8 & 1.38 & 20 & 15.2 & 0.62 & 20 & 1.05 & 0.02 & 20 & 18.0 & 1.17 \\
\hline \multirow[t]{12}{*}{ GRT } & 19APR1994 & 20 & 105.9 & 2.50 & 20 & 13.0 & 0.84 & 20 & 1.08 & 0.02 & 20 & 11.8 & 1.10 \\
\hline & 21APR1994 & 3 & 110.3 & 2.96 & 3 & 14.5 & 1.25 & 3 & 1.07 & 0.06 & 3 & 12.9 & 4.21 \\
\hline & 26APR1994 & 5 & 106.4 & 3.66 & 5 & 13.0 & 1.46 & 5 & 1.06 & 0.03 & 5 & 16.0 & 1.98 \\
\hline & 28APR1994 & 3 & 107.7 & 1.76 & 3 & 13.5 & 0.92 & 3 & 1.08 & 0.04 & 3 & 13.6 & 2.37 \\
\hline & 03MAY1994 & 7 & 113.3 & 4.19 & 7 & 15.1 & 3.12 & 7 & 1.00 & 0.16 & 7 & 22.9 & 2.39 \\
\hline & 05MAY1994 & 15 & 109.2 & 2.01 & 15 & 14.6 & 0.67 & 15 & 1.11 & 0.02 & 15 & 20.7 & 1.40 \\
\hline & 10MAY1994 & 11 & 103.3 & 2.07 & 11 & 12.5 & 0.78 & 11 & 1.12 & 0.01 & 10 & 10.8 & 1.21 \\
\hline & 12MAY1994 & 4 & 102.8 & 7.32 & 4 & 13.0 & 2.70 & 4 & 1.14 & 0.05 & 3 & 20.2 & 0.86 \\
\hline & 17MAY1994 & 1 & 97.0 & & 1 & 9.9 & & 1 & 1.08 & & 0 & & . \\
\hline & 18MAY1994 & 4 & 103.3 & 10.71 & 4 & 13.4 & 3.16 & 4 & 1.12 & 0.06 & 2 & 8.3 & 0.28 \\
\hline & 24MAY1994 & 6 & 103.3 & 4.18 & 6 & 13.4 & 1.51 & 6 & 1.19 & 0.02 & 5 & 14.7 & 0.92 \\
\hline & 26MAY1994 & 3 & 95.3 & 2.33 & 3 & 10.2 & 0.92 & 3 & 1.18 & 0.05 & 3 & 8.8 & 0.70 \\
\hline \multirow[t]{5}{*}{ IMT } & 05APR1994 & 20 & 105.4 & 1.12 & 19 & 11.9 & 0.39 & 19 & 1.02 & 0.02 & 21 & 11.0 & 0.98 \\
\hline & 12APR1994 & 76 & 109.7 & 0.99 & 76 & 13.5 & 0.37 & 76 & 1.00 & 0.01 & 76 & 15.3 & 0.50 \\
\hline & 26APR1994 & 52 & 102.8 & 1.20 & 52 & 12.7 & 0.45 & 52 & 1.14 & 0.01 & 50 & 10.6 & 0.54 \\
\hline & 03MAY1994 & 26 & 101.8 & 1.44 & 26 & 11.5 & 0.51 & 26 & 1.07 & 0.02 & 25 & 14.7 & 0.77 \\
\hline & 04MAY1994 & 54 & 104.0 & 1.85 & 54 & 11.4 & 0.29 & 54 & 1.05 & 0.03 & 51 & 14.5 & 0.59 \\
\hline \multirow[t]{14}{*}{ LGR } & 20APR1994 & 20 & 142.8 & 5.24 & 20 & 30.5 & 5.39 & 20 & 0.96 & 0.02 & 19 & 29.5 & 1.96 \\
\hline & 22APR1994 & 20 & 124.5 & 1.66 & 20 & 19.1 & 0.84 & 20 & 0.98 & 0.01 & 20 & 30.8 & 2.44 \\
\hline & 25APR1994 & 20 & 118.4 & 2.17 & 20 & 19.0 & 1.01 & 20 & 1.13 & 0.03 & 20 & 23.7 & 1.10 \\
\hline & 27APR1994 & 20 & 116.7 & 2.42 & 20 & 14.8 & 0.88 & 20 & 0.91 & 0.01 & 20 & 22.2 & 1.53 \\
\hline & 29APR1994 & 20 & 116.3 & 2.14 & 20 & 14.6 & 0.91 & 20 & 0.91 & 0.02 & 20 & 21.7 & 1.45 \\
\hline & 04MAY1994 & 28 & 114.5 & 2.06 & 28 & 14.8 & 0.80 & 28 & 0.97 & 0.02 & 28 & 20.0 & 1.32 \\
\hline & 06MAY1994 & 31 & 116.8 & 1.98 & 31 & 14.8 & 0.74 & 31 & 0.91 & 0.02 & 31 & 24.2 & 1.03 \\
\hline & 09MAY1994 & 20 & 116.5 & 3.23 & 20 & 14.2 & 1.07 & 20 & 0.88 & 0.02 & 16 & 19.9 & 1.27 \\
\hline & 11 MAY1994 & 20 & 112.1 & 1.88 & 20 & 14.1 & 0.75 & 20 & 0.98 & 0.02 & 17 & 25.7 & 1.84 \\
\hline & 13MAY1994 & 21 & 106.7 & 2.02 & 21 & 13.1 & 0.74 & 21 & 1.06 & 0.01 & 14 & 20.6 & 1.16 \\
\hline & 16MAY1994 & 20 & 110.7 & 1.97 & 20 & 13.6 & 0.71 & 20 & 0.99 & 0.01 & 20 & 22.8 & 2.01 \\
\hline & 18MAY1994 & 20 & 110.5 & 1.99 & 20 & 13.3 & 0.80 & 20 & 0.97 & 0.01 & 20 & 26.2 & 1.90 \\
\hline & 20MAY1994 & 20 & 113.2 & 1.77 & 20 & 14.5 & 0.62 & 20 & 0.99 & 0.01 & 20 & 21.1 & 1.67 \\
\hline & 23MAY1994 & 20 & 113.1 & 1.45 & 20 & 14.3 & 0.46 & 20 & 0.99 & 0.02 & 20 & 18.9 & 1.52 \\
\hline
\end{tabular}


Appendix K. Summary of selected data from subyearling fall chinook salmon collected from the migration-atlarge at John Day Dam (JDA), McNary Dam (MCN), and Rock Island Dam (RIS) during spring 1994. Data includes sample size (N), mean (MEAN), and standard error (STDERR) of fork length in millimeters, wet weight in grams, condition factor (KFACTOR), and gill $\mathrm{Na}^{+}, \mathrm{K}^{+}$-ATPase activity (ATPase) in $\mu \mathrm{mol} \mathrm{P}_{\mathrm{i}} \cdot \mathrm{mg}$ $\operatorname{protein}^{-1} \cdot \mathrm{h}^{-1}$.

\begin{tabular}{|c|c|c|c|c|c|c|c|c|c|c|c|c|c|}
\hline & & \multirow{2}{*}{\multicolumn{3}{|c|}{ FORK LENGTH }} & \multirow{2}{*}{\multicolumn{3}{|c|}{ WEIGHT }} & \multicolumn{3}{|c|}{ KFACTOR } & \multicolumn{3}{|c|}{ ATPase } \\
\hline & & & & & & & & \multirow[b]{2}{*}{$\mathrm{N}$} & \multirow[b]{2}{*}{ MEAN } & \multirow{2}{*}{$\begin{array}{l}\text { STD- } \\
\text { ERR }\end{array}$} & \multirow[b]{2}{*}{$\mathbf{N}$} & \multirow[b]{2}{*}{ MEAN } & \multirow{2}{*}{$\begin{array}{r}\text { STD- } \\
\text { ERR }\end{array}$} \\
\hline & & N & MEAN & STDERR & N & MEAN & STDERR & & & & & & \\
\hline SITE & DATE & & & & & & & & & & & & \\
\hline \multirow[t]{17}{*}{ MCN } & 21JUN1994 & 20 & 116.8 & 1.66 & 20 & 17.5 & 0.79 & 20 & 1.08 & 0.01 & 20 & 16.9 & 1.24 \\
\hline & 27JUN1994 & 20 & 105.2 & 1.64 & 20 & 11.4 & 0.54 & 20 & 0.97 & 0.01 & 19 & 14.2 & 1.16 \\
\hline & 28JUN1994 & 20 & 108.0 & 1.08 & 20 & 11.9 & 0.38 & 20 & 0.94 & 0.01 & 20 & 14.0 & 0.87 \\
\hline & 29JUN1994 & 20 & 104.4 & 1.22 & 20 & 10.9 & 0.41 & 20 & 0.95 & 0.01 & 20 & 17.1 & 1.20 \\
\hline & 06JUL1994 & 21 & 112.2 & 1.56 & 21 & 14.9 & 0.71 & 21 & 1.05 & 0.02 & 21 & 21.7 & 0.94 \\
\hline & 07JUL1994 & 22 & 109.9 & 0.85 & 22 & 13.4 & 0.28 & 22 & 1.01 & 0.01 & 19 & 25.0 & 1.23 \\
\hline & 08JUL1994 & 28 & 109.6 & 1.03 & 28 & 13.2 & 0.38 & 28 & 1.00 & 0.01 & 27 & 23.2 & 1.09 \\
\hline & 11JUL1994 & 23 & 107.4 & 1.31 & 23 & 13.6 & 0.51 & 23 & 1.09 & 0.02 & 23 & 22.4 & 1.18 \\
\hline & 03AUG1994 & 20 & 128.3 & 2.56 & 20 & 26.4 & 1.59 & 20 & 1.23 & 0.02 & 20 & 17.1 & 0.88 \\
\hline & 09AUG1994 & 20 & 133.1 & 1.96 & 20 & 29.4 & 1.32 & 20 & 1.23 & 0.01 & 18 & 14.5 & 1.18 \\
\hline & 16AUG1994 & 20 & 141.2 & 1.42 & 20 & 34.4 & 0.97 & 20 & 1.22 & 0.01 & 20 & 13.2 & 0.66 \\
\hline & 23AUG1994 & 20 & 141.0 & 1.89 & 20 & 35.6 & 1.62 & 20 & 1.26 & 0.02 & 19 & 11.7 & 0.92 \\
\hline & 30AUG1994 & 20 & 146.4 & 2.24 & 20 & 37.5 & 1.70 & 20 & 1.18 & 0.02 & 20 & 13.9 & 1.12 \\
\hline & 08SEP1994 & 20 & 147.6 & 1.74 & 20 & 37.3 & 1.37 & 20 & 1.15 & 0.01 & 20 & 15.6 & 0.93 \\
\hline & 14SEP1994 & 20 & 149.0 & 1.95 & 20 & 37.8 & 1.57 & 20 & 1.13 & 0.02 & 20 & 15.2 & 0.97 \\
\hline & 20SEP1994 & 20 & 147.5 & 3.33 & 19 & 37.5 & 2.47 & 19 & 1.11 & 0.01 & 19 & 11.5 & 0.89 \\
\hline & 28SEP1994 & 20 & 146.6 & 2.39 & 20 & 34.6 & 2.20 & 20 & 1.07 & 0.02 & 19 & 9.9 & 0.69 \\
\hline \multirow[t]{32}{*}{ RIS } & 15JUN1994 & 10 & 109.8 & 5.77 & 10 & 15.0 & 2.21 & 10 & 1.05 & 0.04 & 10 & 15.1 & 0.98 \\
\hline & 16JUN1994 & 7 & 105.7 & 9.29 & 7 & 14.5 & 3.61 & 7 & 1.05 & 0.04 & 7 & 12.2 & 1.33 \\
\hline & 17JUN1994 & 13 & 106.7 & 5.52 & 13 & 14.3 & 2.11 & 13 & 1.06 & 0.03 & 10 & 12.6 & 0.65 \\
\hline & 20JUN1994 & 10 & 119.2 & 7.12 & 10 & 19.3 & 3.13 & 10 & 1.02 & 0.02 & 9 & 13.9 & 1.07 \\
\hline & 21JUN1994 & 10 & 123.9 & 7.74 & 9 & 22.2 & 3.51 & 9 & 0.99 & 0.01 & 8 & 14.5 & 1.11 \\
\hline & 22JUN1994 & 10 & 111.9 & 5.01 & 10 & 16.1 & 2.06 & 10 & 1.11 & 0.02 & 8 & 14.1 & 1.97 \\
\hline & 27JUN1994 & 10 & 104.2 & 2.47 & 10 & 12.2 & 0.94 & 10 & 1.06 & 0.02 & 8 & 11.9 & 1.10 \\
\hline & 28JUN1994 & 10 & 103.0 & 3.38 & 10 & 12.1 & 1.14 & 10 & 1.07 & 0.02 & 9 & 13.5 & 1.99 \\
\hline & 29JUN1994 & 10 & 101.1 & 2.34 & 10 & 11.1 & 1.03 & 10 & 1.05 & 0.03 & 9 & 14.6 & 2.31 \\
\hline & 04JUL1994 & 10 & 96.3 & 3.99 & 10 & 9.8 & 1.17 & 10 & 1.06 & 0.03 & 8 & 12.9 & 1.15 \\
\hline & 05JUL1994 & 10 & 87.3 & 5.12 & 10 & 7.3 & 1.30 & 10 & 1.00 & 0.02 & 8 & 14.6 & 2.25 \\
\hline & 06JUL1994 & 10 & 99.0 & 5.66 & 10 & 11.2 & 2.10 & 10 & 1.05 & 0.02 & 5 & 16.2 & 3.95 \\
\hline & 11JUL1994 & 10 & 106.6 & 4.96 & 10 & 13.9 & 1.86 & 10 & 1.09 & 0.02 & 9 & 17.3 & 1.71 \\
\hline & 12JUL1994 & 10 & 100.4 & 4.68 & 10 & 12.0 & 1.67 & 10 & 1.11 & 0.03 & 10 & 16.3 & 1.46 \\
\hline & 13JUL1994 & 10 & 96.0 & 3.43 & 10 & 9.8 & 1.08 & 10 & 1.07 & 0.03 & 9 & 8.5 & 0.79 \\
\hline & 18JUL1994 & 10 & 102.1 & 4.73 & 10 & 11.8 & 1.87 & 10 & 1.04 & 0.02 & 10 & 8.6 & 0.91 \\
\hline & 19JUL1994 & 10 & 96.5 & 3.80 & 10 & 9.7 & 1.32 & 10 & 1.01 & 0.02 & 9 & 10.8 & 1.38 \\
\hline & 20JUL1994 & 10 & 100.8 & 4.90 & 10 & 12.1 & 1.75 & 10 & 1.11 & 0.02 & 9 & 10.3 & 0.58 \\
\hline & 25JUL1994 & 10 & 97.2 & 3.38 & 10 & 10.9 & 0.99 & 10 & 1.18 & 0.07 & 10 & 9.2 & 0.81 \\
\hline & 26JUL1994 & 10 & 97.8 & 5.72 & 10 & 11.6 & 2.79 & 10 & 1.10 & 0.03 & 9 & 17.9 & 1.23 \\
\hline & 27JUL1994 & 10 & 111.4 & 5.77 & 10 & 16.6 & 2.58 & 10 & 1.12 & 0.03 & 10 & 14.3 & 1.62 \\
\hline & 01AUG1994 & 10 & 104.3 & 4.88 & 10 & 13.2 & 2.06 & 10 & 1.11 & 0.02 & 7 & 14.8 & 1.47 \\
\hline & 02AUG1994 & 10 & 106.2 & 5.59 & 10 & 14.4 & 2.72 & 10 & 1.12 & 0.02 & 9 & 13.6 & 2.31 \\
\hline & 03AUG1994 & 10 & 118.4 & 6.40 & 10 & 19.1 & 2.99 & 10 & 1.06 & 0.04 & 8 & 15.2 & 2.51 \\
\hline & 08AUG1994 & 10 & 102.8 & 3.84 & 10 & 11.9 & 1.61 & 10 & 1.04 & 0.02 & 8 & 15.4 & 1.27 \\
\hline & 09AUG1994 & 10 & 115.7 & 5.12 & 10 & 17.8 & 3.20 & 10 & 1.05 & 0.04 & 10 & 15.1 & 2.40 \\
\hline & 10AUG1994 & 10 & 112.6 & 6.58 & 10 & 16.7 & 3.11 & 10 & 1.06 & 0.02 & 10 & 13.4 & 1.45 \\
\hline & 15AUG1994 & 10 & 107.3 & 4.17 & 10 & 13.6 & 1.88 & 10 & 1.05 & 0.03 & 10 & 10.1 & 0.75 \\
\hline & 16AUG1994 & 10 & 121.7 & 4.37 & 10 & 20.6 & 1.96 & 10 & 1.12 & 0.04 & 10 & 12.6 & 1.54 \\
\hline & 17AUG1994 & 10 & 103.2 & 3.61 & 10 & 12.9 & 1.23 & 10 & 1.14 & 0.02 & 9 & 10.7 & 1.68 \\
\hline & 22AUG1994 & 8 & 123.4 & 6.48 & 8 & 21.9 & 3.50 & 8 & 1.11 & 0.03 & 8 & 10.0 & 1.17 \\
\hline & 23AUG1994 & 10 & 111.1 & 5.91 & 10 & 17.5 & 3.55 & 10 & 1.15 & 0.04 & 10 & 12.8 & 1.33 \\
\hline
\end{tabular}


Appendix K (continued)

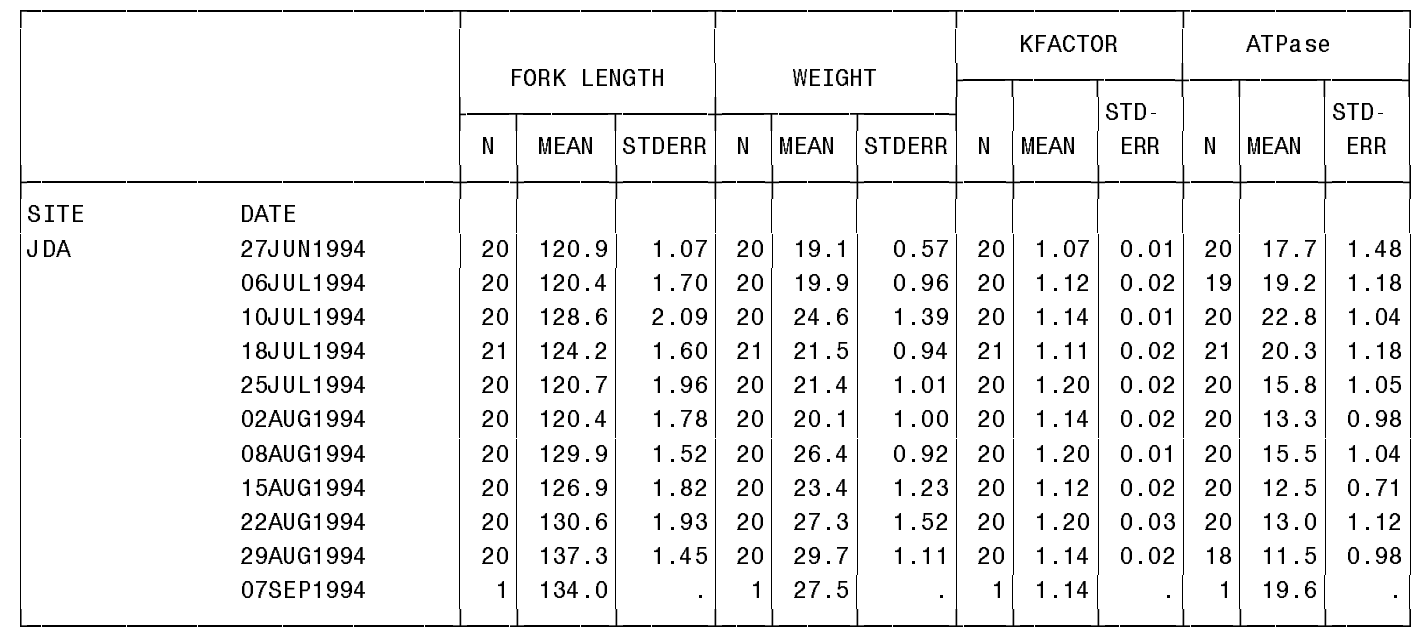


Appendix L. Summary of selected data from hatchery steelhead collected from the migration-at-large at the Snake River Trap at Lewiston (LEW), Salmon River Trap (SRT), Imnaha River Trap (IMT), Grande Ronde River Trap (GRT), Lower Granite Dam (LGR), McNary Dam (MCN), and Rock Island Dam (RIS) during spring 1994. Data includes sample size (N), mean (MEAN), and standard error (STDERR) of fork length in millimeters, wet weight in grams, condition factor (KFACTOR), and gill $\mathrm{Na}^{+}, \mathrm{K}^{+}$-ATPase activity (ATPase) in $\mu \mathrm{mol} \mathrm{P}_{\mathrm{i}} \cdot \mathrm{mg}_{\text {protein }}{ }^{-1} \cdot \mathrm{h}^{-1}$.

\begin{tabular}{|c|c|c|c|c|c|c|c|c|c|c|c|c|c|}
\hline & & \multirow{2}{*}{\multicolumn{3}{|c|}{ FORK LENGTH }} & \multirow{2}{*}{\multicolumn{3}{|c|}{ WEIGHT }} & \multicolumn{3}{|c|}{ KFACTOR } & \multicolumn{3}{|c|}{ ATPase } \\
\hline & & & & & & & & \multirow[b]{2}{*}{ N } & \multirow[b]{2}{*}{ MEAN } & \multirow{2}{*}{$\begin{array}{l}\text { STD- } \\
\text { ERR }\end{array}$} & \multirow[b]{2}{*}{$\mathbf{N}$} & \multirow[b]{2}{*}{ MEAN } & \multirow{2}{*}{$\begin{array}{r}\text { STD- } \\
\text { ERR }\end{array}$} \\
\hline & & N & MEAN & STDERR & N & MEAN & STDERR & & & & & & \\
\hline SITE & DATE & & & & & & & & & & & & \\
\hline \multirow[t]{19}{*}{ LEW } & 13APR1994 & 4 & 202.8 & 5.45 & 4 & 84.4 & 5.48 & 4 & 1.01 & 0.02 & 4 & 9.9 & 3.84 \\
\hline & 15APR1994 & 5 & 232.6 & 12.20 & 5 & 111.2 & 15.32 & 5 & 0.86 & 0.02 & 5 & 13.2 & 0.92 \\
\hline & 20APR1994 & 11 & 213.3 & 6.38 & 11 & 91.5 & 9.82 & 11 & 0.91 & 0.01 & 10 & 7.3 & 0.80 \\
\hline & 22APR1994 & 17 & 206.4 & 4.14 & 17 & 84.2 & 5.19 & 17 & 0.94 & 0.01 & 17 & 7.8 & 0.57 \\
\hline & 25APR1994 & 17 & 211.5 & 3.47 & 17 & 83.7 & 6.82 & 17 & 0.88 & 0.05 & 17 & 11.0 & 0.97 \\
\hline & 27APR1994 & 11 & 208.8 & 4.34 & 11 & 87.6 & 5.60 & 11 & 0.95 & 0.01 & 11 & 10.7 & 0.67 \\
\hline & 29APR1994 & 12 & 205.5 & 4.92 & 12 & 75.2 & 7.83 & 12 & 0.88 & 0.07 & 11 & 8.3 & 0.85 \\
\hline & 02MAY1994 & 13 & 217.2 & 8.34 & 13 & 99.8 & 10.32 & 13 & 0.92 & 0.01 & 12 & 8.5 & 0.90 \\
\hline & 04MAY1994 & 11 & 215.5 & 7.14 & 11 & 98.4 & 8.99 & 11 & 0.95 & 0.01 & 11 & 10.9 & 1.50 \\
\hline & 06MAY1994 & 12 & 216.5 & 5.91 & 11 & 94.5 & 6.05 & 11 & 0.97 & 0.01 & 11 & 9.2 & 0.94 \\
\hline & 09MAY1994 & 12 & 216.7 & 6.82 & 12 & 94.1 & 9.12 & 12 & 0.90 & 0.01 & 12 & 7.2 & 0.75 \\
\hline & 11 MAY1994 & 12 & 209.3 & 7.30 & 12 & 81.7 & 8.34 & 12 & 0.85 & 0.01 & 12 & 9.6 & 1.25 \\
\hline & 13MAY1994 & 12 & 224.0 & 7.43 & 12 & 104.6 & 9.61 & 12 & 0.91 & 0.02 & 12 & 9.1 & 0.59 \\
\hline & 16MAY1994 & 12 & 207.8 & 6.26 & 12 & 77.7 & 7.28 & 12 & 0.84 & 0.01 & 12 & 7.4 & 0.44 \\
\hline & $18 M A Y 1994$ & 12 & 221.2 & 8.56 & 12 & 92.5 & 13.27 & 12 & 0.80 & 0.01 & 9 & 10.8 & 1.45 \\
\hline & 19MAY1994 & 12 & 216.8 & 6.41 & 11 & 90.1 & 9.07 & 11 & 0.85 & 0.01 & 11 & 8.3 & 0.90 \\
\hline & 23MAY1994 & 11 & 212.3 & 5.96 & 11 & 89.1 & 9.38 & 11 & 0.90 & 0.02 & 10 & 8.2 & 0.64 \\
\hline & 25MAY1994 & 12 & 219.5 & 7.06 & 12 & 96.5 & 12.77 & 12 & 0.87 & 0.02 & 12 & 8.7 & 0.78 \\
\hline & 27MAY1994 & 12 & 229.0 & 7.94 & 12 & 109.5 & 12.38 & 12 & 0.87 & 0.02 & 12 & 8.4 & 0.91 \\
\hline \multirow[t]{12}{*}{ SRT } & 19APR1994 & 25 & 221.5 & 4.29 & 25 & 103.2 & 6.46 & 25 & 0.93 & 0.01 & 25 & 9.7 & 0.39 \\
\hline & 21APR1994 & 25 & 211.8 & 5.34 & 25 & 93.0 & 9.60 & 25 & 0.92 & 0.02 & 24 & 8.3 & 0.49 \\
\hline & 26APR1994 & 30 & 213.6 & 3.27 & 30 & 86.5 & 4.00 & 30 & 0.87 & 0.01 & 30 & 9.7 & 0.49 \\
\hline & 28APR1994 & 30 & 208.2 & 4.26 & 30 & 91.4 & 5.43 & 30 & 0.98 & 0.01 & 29 & 8.7 & 0.48 \\
\hline & 03MAY1994 & 31 & 222.9 & 3.22 & 31 & 100.5 & 4.56 & 31 & 0.89 & 0.01 & 31 & 9.8 & 0.73 \\
\hline & 05MAY1994 & 30 & 216.8 & 3.52 & 30 & 99.0 & 4.63 & 30 & 0.95 & 0.01 & 28 & 9.3 & 0.76 \\
\hline & 10MAY1994 & 25 & 210.5 & 3.95 & 25 & 86.8 & 5.01 & 25 & 0.91 & 0.01 & 25 & 9.5 & 0.42 \\
\hline & 12 MAY1994 & 30 & 205.4 & 3.39 & 30 & 79.4 & 4.16 & 30 & 0.90 & 0.01 & 30 & 9.3 & 0.51 \\
\hline & 17 MAY1994 & 19 & 211.7 & 5.74 & 19 & 82.1 & 6.71 & 19 & 0.83 & 0.01 & 16 & 8.6 & 0.90 \\
\hline & 19MAY1994 & 23 & 209.1 & 5.86 & 23 & 83.0 & 6.67 & 23 & 0.87 & 0.02 & 19 & 8.7 & 0.71 \\
\hline & 24MAY1994 & 25 & 209.2 & 3.83 & 25 & 77.4 & 4.33 & 25 & 0.82 & 0.01 & 24 & 8.0 & 0.56 \\
\hline & 26MAY1994 & 25 & 200.1 & 4.98 & 25 & 68.0 & 5.26 & 25 & 0.81 & 0.01 & 21 & 7.0 & 0.67 \\
\hline \multirow[t]{11}{*}{ GRT } & 19APR1994 & 25 & 212.1 & 2.91 & 25 & 94.7 & 4.05 & 25 & 0.98 & 0.01 & 24 & 9.5 & 0.68 \\
\hline & 26APR1994 & 25 & 214.0 & 5.06 & 25 & 97.2 & 7.11 & 25 & 0.95 & 0.01 & 24 & 6.8 & 0.58 \\
\hline & 28APR1994 & 3 & 224.3 & 6.57 & 3 & 118.6 & 14.09 & 3 & 1.04 & 0.03 & 3 & 8.5 & 1.79 \\
\hline & 03MAY1994 & 22 & 219.4 & 4.79 & 22 & 105.6 & 7.13 & 22 & 0.97 & 0.01 & 22 & 7.6 & 0.43 \\
\hline & 05 MAY1994 & 25 & 220.2 & 4.04 & 25 & 108.6 & 6.21 & 25 & 0.99 & 0.01 & 25 & 5.8 & 0.40 \\
\hline & 10MAY1994 & 25 & 220.6 & 4.72 & 25 & 107.1 & 6.78 & 25 & 0.97 & 0.01 & 21 & 6.3 & 0.64 \\
\hline & 12 MAY1994 & 25 & 215.0 & 4.00 & 25 & 99.3 & 6.07 & 25 & 0.97 & 0.01 & 24 & 7.8 & 0.57 \\
\hline & 17MAY1994 & 26 & 215.7 & 4.07 & 25 & 102.1 & 6.43 & 25 & 0.98 & 0.01 & 24 & 6.3 & 0.42 \\
\hline & 18MAY1994 & 25 & 208.7 & 3.12 & 25 & 87.1 & 3.87 & 25 & 0.95 & 0.01 & 23 & 5.7 & 0.40 \\
\hline & 24MAY1994 & 21 & 219.0 & 4.16 & 21 & 104.8 & 5.87 & 21 & 0.98 & 0.02 & 21 & 8.7 & 0.56 \\
\hline & 26 MAY1994 & 25 & 227.6 & 4.76 & 25 & 118.0 & 8.04 & 25 & 0.97 & 0.01 & 24 & 8.8 & 0.49 \\
\hline \multirow[t]{5}{*}{ IMT } & 26APR1994 & 30 & 216.9 & 2.77 & 30 & 105.6 & 4.68 & 30 & 1.02 & 0.01 & 28 & 7.6 & 0.34 \\
\hline & 27APR1994 & 30 & 209.0 & 4.00 & 30 & 102.4 & 6.13 & 30 & 1.09 & 0.01 & 30 & 7.7 & 0.75 \\
\hline & 28APR1994 & 30 & 211.8 & 3.57 & 19 & 99.4 & 5.95 & 19 & 1.02 & 0.01 & 30 & 7.9 & 0.51 \\
\hline & 03MAY1994 & 13 & 214.1 & 4.59 & 13 & 104.5 & 8.35 & 13 & 1.04 & 0.02 & 13 & 10.4 & 0.95 \\
\hline & 04 MAY1994 & 26 & 216.7 & 4.31 & 26 & 111.6 & 7.35 & 26 & 1.06 & 0.01 & 26 & 9.5 & 0.64 \\
\hline
\end{tabular}


Appendix L (continued)

\begin{tabular}{|c|c|c|c|c|c|c|c|c|c|c|c|c|c|}
\hline & & \multirow{2}{*}{\multicolumn{3}{|c|}{ FORK LENGTH }} & \multirow{2}{*}{\multicolumn{3}{|c|}{ WEIGHT }} & \multicolumn{3}{|c|}{ KFACTOR } & \multicolumn{3}{|c|}{ ATPase } \\
\hline & & & & & & & & \multirow[b]{2}{*}{$N$} & \multirow[b]{2}{*}{ MEAN } & \multirow{2}{*}{$\begin{array}{r}\text { STD - } \\
\text { ERR }\end{array}$} & \multirow[b]{2}{*}{$N$} & \multirow[b]{2}{*}{ MEAN } & \multirow{2}{*}{$\begin{array}{r}\text { STD- } \\
\text { ERR }\end{array}$} \\
\hline & & $N$ & MEAN & STDERR & $N$ & MEAN & STDERR & & & & & & \\
\hline SITE & DATE & & & & & & & & & & & & \\
\hline \multirow[t]{11}{*}{ LGR } & 27APR1994 & 11 & 212.2 & 7.16 & 11 & 82.9 & 9.99 & 11 & 0.83 & 0.01 & 11 & 13.0 & 0.99 \\
\hline & 29APR1994 & 12 & 210.9 & 5.11 & 12 & 83.0 & 5.54 & 12 & 0.87 & 0.01 & 12 & 13.2 & 1.38 \\
\hline & 04MAY1994 & 18 & 208.4 & 6.15 & 18 & 84.8 & 7.42 & 18 & 0.90 & 0.02 & 17 & 16.2 & 0.83 \\
\hline & 06MAY1994 & 12 & 218.4 & 5.28 & 12 & 92.1 & 5.65 & 12 & 0.88 & 0.02 & 12 & 13.9 & 1.10 \\
\hline & 09MAY1994 & 12 & 212.3 & 6.27 & 12 & 81.7 & 7.85 & 12 & 0.83 & 0.01 & 12 & 11.9 & 1.21 \\
\hline & 11 MAY1994 & 12 & 217.2 & 5.90 & 12 & 92.6 & 7.99 & 12 & 0.88 & 0.01 & 12 & 14.8 & 1.29 \\
\hline & 13MAY1994 & 11 & 208.2 & 7.04 & 11 & 81.8 & 8.46 & 11 & 0.88 & 0.01 & 11 & 16.3 & 1.13 \\
\hline & 16MAY1994 & 12 & 217.8 & 6.45 & 12 & 88.1 & 6.47 & 12 & 0.84 & 0.02 & 12 & 11.8 & 1.21 \\
\hline & 19MAY1994 & 30 & 207.8 & 3.85 & 0 & & & 0 & & & 29 & 13.3 & 0.97 \\
\hline & 20MAY1994 & 12 & 218.1 & 5.21 & 12 & 88.3 & 7.19 & 12 & 0.83 & 0.02 & 11 & 14.6 & 0.71 \\
\hline & 23MAY1994 & 4 & 220.5 & 2.25 & 4 & 84.6 & 3.15 & 4 & 0.79 & 0.02 & 4 & 10.7 & 1.43 \\
\hline \multirow[t]{6}{*}{ MCN } & 26APR1994 & 10 & 235.3 & 13.07 & 10 & 126.9 & 13.58 & 10 & 0.92 & 0.02 & 10 & 13.3 & 1.30 \\
\hline & 03MAY1994 & 20 & 218.7 & 6.14 & 20 & 86.6 & 8.40 & 20 & 0.78 & 0.01 & 20 & 10.9 & 0.65 \\
\hline & 10MAY1994 & 20 & 217.1 & 6.49 & 20 & 92.4 & 8.83 & 20 & 0.86 & 0.02 & 19 & 11.3 & 1.26 \\
\hline & 17MAY1994 & 20 & 227.5 & 5.96 & 20 & 99.1 & 7.83 & 20 & 0.81 & 0.01 & 19 & 15.0 & 1.60 \\
\hline & 24MAY1994 & 20 & 224.7 & 5.09 & 20 & 91.2 & 6.29 & 20 & 0.78 & 0.01 & 20 & 12.0 & 0.92 \\
\hline & 01JUN1994 & 20 & 230.6 & 6.44 & 20 & 96.6 & 8.03 & 20 & 0.75 & 0.01 & 16 & 11.1 & 0.97 \\
\hline \multirow[t]{16}{*}{ RIS } & 21APR1994 & 23 & 209.0 & 2.65 & 0 & . & . & 0 & &. & 23 & 13.8 & 0.88 \\
\hline & 25APR1994 & 20 & 209.4 & 4.91 & 11 & 81.4 & 6.94 & 11 & 0.90 & 0.02 & 20 & 14.8 & 0.98 \\
\hline & 26APR1994 & 20 & 222.8 & 2.74 & 19 & 98.4 & 4.34 & 19 & 0.88 & 0.01 & 20 & 15.6 & 0.83 \\
\hline & 27APR1994 & 21 & 224.9 & 4.41 & 21 & 100.4 & 6.28 & 21 & 0.86 & 0.01 & 20 & 15.6 & 0.60 \\
\hline & 28APR1994 & 20 & 223.2 & 3.56 & 20 & 93.9 & 4.25 & 20 & 0.84 & 0.02 & 19 & 19.1 & 1.39 \\
\hline & 02MAY1994 & 21 & 241.1 & 5.97 & 0 & &. & 0 & . & . & 20 & 12.2 & 0.76 \\
\hline & 03MAY1994 & 19 & 216.0 & 5.18 & 19 & 93.2 & 6.39 & 19 & 0.90 & 0.01 & 19 & 15.5 & 0.96 \\
\hline & 04MAY1994 & 19 & 222.9 & 4.69 & 19 & 100.2 & 6.72 & 19 & 0.88 & 0.01 & 19 & 16.4 & 0.89 \\
\hline & 05MAY1994 & 20 & 216.0 & 2.59 & 20 & 87.9 & 3.52 & 20 & 0.86 & 0.01 & 20 & 14.5 & 0.73 \\
\hline & 09MAY1994 & 20 & 217.3 & 3.31 & 20 & 86.5 & 4.25 & 20 & 0.83 & 0.01 & 20 & 15.6 & 1.28 \\
\hline & 10MAY1994 & 20 & 212.9 & 4.41 & 20 & 86.3 & 5.40 & 20 & 0.87 & 0.01 & 18 & 15.6 & 1.06 \\
\hline & 11MAY1994 & 20 & 217.4 & 4.37 & 19 & 92.0 & 5.57 & 19 & 0.86 & 0.01 & 20 & 13.6 & 0.81 \\
\hline & 12MAY1994 & 21 & 217.5 & 3.79 & 21 & 89.9 & 5.55 & 21 & 0.85 & 0.02 & 21 & 14.5 & 0.91 \\
\hline & 16MAY1994 & 20 & 217.4 & 7.84 & 19 & 94.1 & 11.55 & 19 & 0.84 & 0.01 & 19 & 13.9 & 0.89 \\
\hline & 17MAY1994 & 20 & 222.7 & 5.56 & 20 & 97.3 & 7.80 & 20 & 0.85 & 0.01 & 18 & 16.8 & 1.01 \\
\hline & 18MAY1994 & 20 & 224.8 & 6.68 & 20 & 103.1 & 8.91 & 20 & 0.86 & 0.01 & 19 & 15.9 & 1.04 \\
\hline
\end{tabular}


Appendix M. Summary of selected data from wild steelhead collected from the migration-at-large at the Snake River Trap at Lewiston (LEW), Salmon River Trap (SRT), Imnaha River Trap (IMT), Grande Ronde River Trap (GRT), Lower Granite Dam (LGR), McNary Dam (MCN), and Rock Island Dam (RIS) during spring 1994. Data includes sample size (N), mean (MEAN), and standard error (STDERR) of fork length in millimeters, wet weight in grams, condition factor (KFACTOR), and gill $\mathrm{Na}^{+}, \mathrm{K}^{+}$-ATPase activity (ATPase) in $\mu \mathrm{mol} \mathrm{P}_{\mathrm{i}} \cdot \mathrm{mg}_{\text {protein }}{ }^{-1} \cdot \mathrm{h}^{-1}$.

\begin{tabular}{|c|c|c|c|c|c|c|c|c|c|c|c|c|c|}
\hline & & \multirow{2}{*}{\multicolumn{3}{|c|}{ FORK LENGTH }} & \multirow{2}{*}{\multicolumn{3}{|c|}{ WEIGHT }} & \multicolumn{3}{|c|}{ KFACTOR } & \multicolumn{3}{|c|}{ ATPase } \\
\hline & & & & & & & & \multirow[b]{2}{*}{$\mathrm{N}$} & \multirow[b]{2}{*}{ MEAN } & \multirow{2}{*}{$\begin{array}{l}\text { STD- } \\
\text { ERR }\end{array}$} & \multirow[b]{2}{*}{$\mathbf{N}$} & \multirow[b]{2}{*}{ MEAN } & \multirow{2}{*}{$\begin{array}{r}\text { STD- } \\
\text { ERR }\end{array}$} \\
\hline & & N & MEAN & STDERR & N & MEAN & STDERR & & & & & & \\
\hline SITE & DATE & & & & & & & & & & & & \\
\hline \multirow[t]{19}{*}{ LEW } & 13APR1994 & 4 & 204.0 & 10.40 & 4 & 75.6 & 11.56 & 4 & 0.86 & 0.03 & 4 & 7.6 & 0.65 \\
\hline & 15APR1994 & 2 & 173.5 & 9.50 & 2 & 42.0 & 7.65 & 2 & 0.79 & 0.02 & 2 & 14.5 & 1.00 \\
\hline & 20APR1994 & 12 & 164.9 & 5.53 & 12 & 40.7 & 4.67 & 12 & 0.86 & 0.02 & 11 & 8.5 & 0.96 \\
\hline & 22APR1994 & 17 & 169.9 & 3.80 & 17 & 45.9 & 3.01 & 17 & 0.92 & 0.02 & 17 & 10.8 & 0.87 \\
\hline & 25APR1994 & 17 & 183.1 & 5.33 & 17 & 54.2 & 4.95 & 17 & 0.85 & 0.02 & 17 & 12.6 & 1.25 \\
\hline & 27APR1994 & 12 & 164.8 & 5.54 & 12 & 43.0 & 4.59 & 12 & 0.93 & 0.02 & 12 & 11.4 & 0.87 \\
\hline & 29APR1994 & 12 & 167.2 & 3.62 & 12 & 44.3 & 2.94 & 12 & 0.94 & 0.02 & 12 & 14.7 & 1.55 \\
\hline & $02 M A Y 1994$ & 12 & 170.8 & 4.26 & 12 & 46.5 & 3.57 & 12 & 0.91 & 0.02 & 12 & 16.1 & 1.62 \\
\hline & 04 MAY1994 & 12 & 175.6 & 6.07 & 12 & 51.3 & 5.34 & 12 & 0.91 & 0.01 & 12 & 11.0 & 1.02 \\
\hline & 06MAY1994 & 12 & 179.1 & 3.67 & 12 & 53.4 & 3.52 & 12 & 0.92 & 0.02 & 12 & 14.9 & 1.33 \\
\hline & $09 M A Y 1994$ & 12 & 174.1 & 5.55 & 12 & 48.8 & 4.83 & 12 & 0.89 & 0.02 & 12 & 9.6 & 0.63 \\
\hline & 11MAY1994 & 12 & 170.4 & 3.87 & 12 & 46.1 & 3.40 & 12 & 0.91 & 0.02 & 11 & 12.2 & 1.05 \\
\hline & 13MAY1994 & 11 & 169.6 & 5.57 & 11 & 47.6 & 4.25 & 11 & 0.95 & 0.02 & 10 & 10.4 & 1.00 \\
\hline & 16MAY1994 & 12 & 173.2 & 3.68 & 12 & 48.0 & 2.89 & 12 & 0.91 & 0.02 & 11 & 9.3 & 0.85 \\
\hline & 18MAY1994 & 12 & 170.8 & 3.59 & 12 & 45.6 & 3.15 & 12 & 0.90 & 0.02 & 10 & 10.8 & 1.11 \\
\hline & 19MAY1994 & 12 & 167.4 & 4.95 & 12 & 49.5 & 5.03 & 12 & 1.02 & 0.02 & 12 & 9.8 & 0.48 \\
\hline & 23MAY1994 & 12 & 169.8 & 5.40 & 12 & 48.0 & 4.64 & 12 & 0.95 & 0.01 & 9 & 10.5 & 0.72 \\
\hline & 25MAY1994 & 12 & 168.3 & 3.45 & 12 & 47.0 & 2.92 & 12 & 0.97 & 0.01 & 11 & 9.9 & 0.78 \\
\hline & 27MAY1994 & 12 & 167.3 & 5.21 & 12 & 46.8 & 4.03 & 12 & 0.97 & 0.02 & 10 & 6.9 & 0.53 \\
\hline \multirow[t]{15}{*}{ SRT } & 06APR1994 & 1 & 148.0 & & 1 & 29.6 & & 1 & 0.91 & & 1 & 11.2 & \\
\hline & 07 APR1994 & 1 & 160.0 & & 1 & 35.5 & & 1 & 0.87 & & 1 & 10.8 & \\
\hline & 12APR1994 & 1 & 174.0 & & 1 & 46.6 & & 1 & 0.88 & & 1 & 10.9 & \\
\hline & 19APR1994 & 25 & 183.9 & 4.08 & 25 & 54.2 & 4.12 & 25 & 0.86 & 0.03 & 25 & 10.9 & 0.65 \\
\hline & 21APR1994 & 25 & 175.8 & 3.49 & 25 & 47.3 & 2.40 & 25 & 0.86 & 0.02 & 25 & 8.8 & 0.44 \\
\hline & 26APR1994 & 10 & 176.5 & 5.07 & 10 & 48.6 & 4.40 & 10 & 0.87 & 0.02 & 10 & 10.5 & 1.04 \\
\hline & 28APR1994 & 16 & 176.6 & 4.12 & 15 & 49.2 & 3.53 & 15 & 0.88 & 0.02 & 16 & 12.6 & 0.95 \\
\hline & 03MAY1994 & 1 & 192.0 & & 1 & 61.3 & & 1 & 0.87 & & 1 & 13.7 & \\
\hline & 05MAY1994 & 2 & 160.5 & 3.50 & 2 & 42.9 & 3.10 & 2 & 1.04 & 0.01 & 2 & 12.5 & 3.59 \\
\hline & 10MAY1994 & 6 & 164.8 & 4.74 & 6 & 46.0 & 4.50 & 6 & 1.01 & 0.02 & 6 & 10.4 & 1.54 \\
\hline & 12MAY1994 & 14 & 164.0 & 3.88 & 14 & 45.6 & 2.91 & 14 & 1.02 & 0.02 & 14 & 11.8 & 1.06 \\
\hline & 17MAY1994 & 1 & 174.0 & & 1 & 53.7 & & 1 & 1.02 & & 1 & 6.9 & \\
\hline & 19MAY1994 & 4 & 169.0 & 5.35 & 4 & 47.8 & 3.48 & 4 & 0.99 & 0.03 & 4 & 10.6 & 1.35 \\
\hline & 24MAY1994 & 9 & 172.4 & 5.07 & 9 & 48.5 & 4.09 & 9 & 0.93 & 0.03 & 8 & 8.7 & 1.32 \\
\hline & 26MAY1994 & 6 & 172.3 & 5.47 & 6 & 46.1 & 4.23 & 6 & 0.89 & 0.03 & 6 & 6.2 & 0.90 \\
\hline \multirow[t]{12}{*}{ GRT } & 19APR1994 & 23 & 180.8 & 5.93 & 23 & 58.9 & 6.57 & 23 & 0.93 & 0.01 & 23 & 9.3 & 0.66 \\
\hline & 21APR1994 & 20 & 166.1 & 5.18 & 20 & 46.6 & 4.97 & 20 & 0.96 & 0.01 & 19 & 9.5 & 0.85 \\
\hline & 26APR1994 & 3 & 145.3 & 5.36 & 3 & 29.1 & 3.10 & 3 & 0.94 & 0.01 & 3 & 13.0 & 3.19 \\
\hline & 28APR1994 & 8 & 129.6 & 14.75 & 8 & 26.7 & 6.98 & 8 & 1.06 & 0.06 & 8 & 12.2 & 1.62 \\
\hline & 03MAY1994 & 23 & 155.7 & 5.26 & 23 & 39.2 & 3.05 & 23 & 0.98 & 0.01 & 22 & 13.7 & 1.18 \\
\hline & 05MAY1994 & 25 & 164.7 & 3.50 & 25 & 44.9 & 2.65 & 25 & 0.98 & 0.01 & 25 & 14.1 & 1.11 \\
\hline & 10MAY1994 & 25 & 141.1 & 7.03 & 25 & 32.5 & 4.09 & 25 & 0.98 & 0.01 & 21 & 10.5 & 0.95 \\
\hline & 12MAY1994 & 25 & 132.9 & 6.61 & 25 & 29.1 & 4.02 & 25 & 1.06 & 0.02 & 17 & 11.4 & 0.81 \\
\hline & 17MAY1994 & 24 & 154.8 & 5.55 & 24 & 40.8 & 3.78 & 24 & 1.02 & 0.01 & 22 & 8.3 & 0.51 \\
\hline & 18MAY1994 & 18 & 157.6 & 5.39 & 18 & 41.6 & 3.55 & 18 & 1.00 & 0.01 & 15 & 7.9 & 0.57 \\
\hline & 24MAY1994 & 11 & 153.0 & 4.13 & 11 & 37.0 & 3.14 & 11 & 1.01 & 0.01 & 11 & 11.2 & 0.75 \\
\hline & 26MAY1994 & 8 & 159.5 & 5.56 & 8 & 43.7 & 4.60 & 8 & 1.05 & 0.01 & 7 & 13.3 & 1.25 \\
\hline
\end{tabular}


Appendix M (continued)

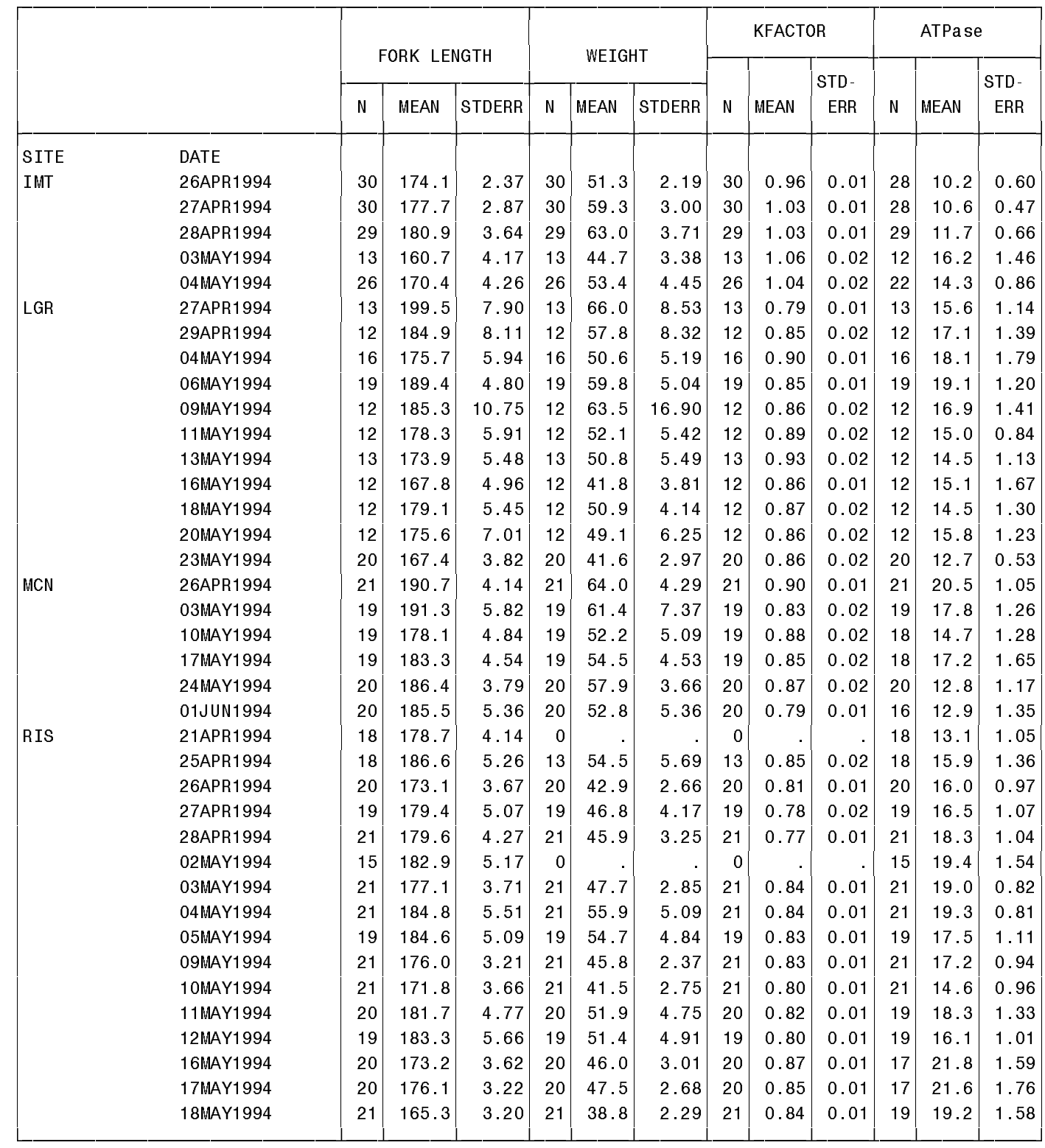


Appendix N.1. Summary of selected data from hatchery sockeye salmon collected at Rock Island Dam (RIS) during spring 1994. Data includes sample size (N), mean (MEAN), and standard error (STDERR) of fork length in millimeters, wet weight in grams, condition factor (KFACTOR), and gill $\mathrm{Na}^{+}, \mathrm{K}^{+}$-ATPase activity (ATPase) in $\mu$ mol $\mathrm{P}_{\mathrm{i}}$. $\operatorname{mg} \operatorname{protein}^{-1} \cdot \mathrm{h}^{-1}$.

\begin{tabular}{|c|c|c|c|c|c|c|c|c|c|c|c|c|c|}
\hline & & \multirow{2}{*}{\multicolumn{3}{|c|}{ FORK LENGTH }} & \multirow{2}{*}{\multicolumn{3}{|c|}{ WEIGHT }} & \multicolumn{3}{|c|}{ KFACTOR } & \multicolumn{3}{|c|}{ ATPase } \\
\hline & & & & & & & & \multirow[b]{2}{*}{$\mathbf{N}$} & \multirow[b]{2}{*}{ MEAN } & \multirow{2}{*}{$\begin{array}{r}\text { STD- } \\
\text { ERR }\end{array}$} & \multirow[b]{2}{*}{$N$} & \multirow[b]{2}{*}{ MEAN } & \multirow{2}{*}{$\begin{array}{r}\text { STD- } \\
\text { ERR }\end{array}$} \\
\hline & & $N$ & MEAN & STDERR & N & MEAN & STDERR & & & & & & \\
\hline SITE & DATE & & & & & & & & & & & & \\
\hline \multirow[t]{20}{*}{ RIS } & 19APR1994 & 1 & 110.0 & . & 0 & . & . & 0 & . & . & 1 & 26.7 & . \\
\hline & 20APR1994 & 1 & 120.0 & & 0 & . & . & 0 & . & . & 1 & 26.3 & . \\
\hline & 21APR1994 & 6 & 103.8 & 3.12 & 0 & . & . & 0 & . &. & 6 & 28.3 & 4.06 \\
\hline & 25APR1994 & 8 & 104.3 & 1.92 & 8 & 8.4 & 0.52 & 8 & 0.73 & 0.01 & 7 & 27.3 & 1.36 \\
\hline & 26APR1994 & 9 & 102.2 & 2.72 & 9 & 8.3 & 0.64 & 9 & 0.76 & 0.01 & 9 & 26.9 & 2.16 \\
\hline & 27APR1994 & 3 & 110.3 & 7.06 & 3 & 9.9 & 1.91 & 3 & 0.72 & 0.02 & 3 & 32.6 & 3.27 \\
\hline & 28APR1994 & 3 & 104.3 & 2.19 & 3 & 8.1 & 0.50 & 3 & 0.71 & 0.01 & 3 & 31.6 & 1.54 \\
\hline & 02MAY1994 & 6 & 115.2 & 2.41 & 0 & & & 0 & &. & 6 & 28.4 & 1.16 \\
\hline & 03MAY1994 & 2 & 117.0 & 12.00 & 2 & 13.2 & 3.95 & 2 & 0.80 & 0.00 & 2 & 28.3 & 6.24 \\
\hline & 04MAY1994 & 1 & 187.0 &. & 1 & 59.8 &. & 1 & 0.91 &. & 1 & 21.7 & . \\
\hline & 09MAY1994 & 9 & 115.7 & 3.21 & 9 & 12.8 & 1.00 & 9 & 0.81 & 0.01 & 9 & 26.7 & 3.40 \\
\hline & 10MAY1994 & 11 & 117.5 & 1.72 & 11 & 13.0 & 0.70 & 11 & 0.79 & 0.02 & 11 & 34.4 & 3.81 \\
\hline & 11 MAY1994 & 2 & 97.5 & 0.50 & 2 & 7.4 & 0.45 & 2 & 0.79 & 0.04 & 1 & 23.0 & . \\
\hline & 12 MAY1994 & 9 & 117.8 & 3.12 & 8 & 13.9 & 1.08 & 8 & 0.86 & 0.02 & 9 & 32.1 & 2.02 \\
\hline & 16MAY1994 & 6 & 119.5 & 3.78 & 5 & 13.3 & 1.43 & 5 & 0.80 & 0.01 & 6 & 43.5 & 1.89 \\
\hline & 17MAY1994 & 1 & 121.0 & & 1 & 13.3 & & 1 & 0.75 & . & 1 & 31.4 & . \\
\hline & 18MAY1994 & 6 & 124.2 & 2.60 & 6 & 15.5 & 0.86 & 6 & 0.81 & 0.02 & 5 & 30.0 & 6.09 \\
\hline & 23MAY1994 & 4 & 123.5 & 3.93 & 4 & 15.6 & 1.16 & 4 & 0.83 & 0.03 & 4 & 30.1 & 5.20 \\
\hline & 24MAY1994 & 3 & 125.0 & 2.31 & 3 & 17.0 & 0.56 & 3 & 0.87 & 0.02 & 3 & 45.4 & 1.13 \\
\hline & 25MAY1994 & 2 & 135.5 & 3.50 & 2 & 20.3 & 0.60 & 2 & 0.82 & 0.09 & 2 & 24.3 & 8.01 \\
\hline
\end{tabular}


Appendix N.2. Summary of selected data from wild sockeye salmon collected at Rock Island Dam (RIS) during spring 1994. Data includes sample size (N), mean (MEAN), and standard error (STDERR) of fork length in millimeters, wet weight in grams, condition factor (KFACTOR), and gill $\mathrm{Na}^{+}, \mathrm{K}^{+}$-ATPase activity (ATPase) in $\mu \mathrm{mol} \mathrm{P}_{\mathrm{i}} \cdot \mathrm{mg}$ protein $^{-1} \cdot \mathrm{h}^{-1}$.

\begin{tabular}{|c|c|c|c|c|c|c|c|c|c|c|c|c|c|}
\hline & & \multirow{2}{*}{\multicolumn{3}{|c|}{ FORK LENGTH }} & \multirow{2}{*}{\multicolumn{3}{|c|}{ WEIGHT }} & \multicolumn{3}{|c|}{ KFACTOR } & \multicolumn{3}{|c|}{ ATPase } \\
\hline & & & & & & & & \multirow[b]{2}{*}{$N$} & \multirow[b]{2}{*}{ MEAN } & \multirow{2}{*}{$\begin{array}{r}\text { STD - } \\
\text { ERR }\end{array}$} & \multirow[b]{2}{*}{$N$} & \multirow[b]{2}{*}{ MEAN } & \multirow{2}{*}{$\begin{array}{r}\text { STD - } \\
\text { ERR }\end{array}$} \\
\hline & & $N$ & MEAN & STDERR & $\mathrm{N}$ & MEAN & STDERR & & & & & & \\
\hline SITE & DATE & & & & & & & & & & & & \\
\hline \multirow[t]{22}{*}{ RIS } & 19APR1994 & 9 & 99.1 & 3.31 & 0 & . & . & 0 &. &. & 9 & 17.6 & 1.48 \\
\hline & 20APR1994 & 10 & 100.0 & 3.68 & 0 & . & . & 0 & . & . & 10 & 15.5 & 2.50 \\
\hline & 21APR1994 & 12 & 93.6 & 2.70 & 0 & . & . & 0 & . & . & 12 & 13.5 & 1.65 \\
\hline & 25APR1994 & 18 & 98.7 & 4.15 & 16 & 6.6 & 0.26 & 16 & 0.75 & 0.05 & 18 & 17.3 & 1.95 \\
\hline & 26APR1994 & 10 & 92.2 & 1.50 & 10 & 6.2 & 0.31 & 10 & 0.78 & 0.01 & 9 & 15.9 & 1.74 \\
\hline & 27APR1994 & 9 & 95.2 & 2.03 & 9 & 6.1 & 0.39 & 9 & 0.70 & 0.01 & 9 & 23.1 & 3.54 \\
\hline & 28APR1994 & 10 & 107.1 & 2.93 & 10 & 10.1 & 1.08 & 10 & 0.79 & 0.03 & 10 & 31.8 & 2.23 \\
\hline & 02MAY1994 & 10 & 112.5 & 2.03 & 0 & . &. & 0 & . &. & 10 & 29.4 & 1.03 \\
\hline & 03MAY1994 & 10 & 102.3 & 3.74 & 10 & 9.9 & 1.14 & 10 & 0.89 & 0.02 & 10 & 21.3 & 3.25 \\
\hline & 04MAY1994 & 10 & 106.6 & 4.68 & 10 & 11.3 & 1.41 & 10 & 0.89 & 0.01 & 9 & 25.2 & 4.01 \\
\hline & 05 MAY1994 & 12 & 112.5 & 3.01 & 12 & 13.2 & 1.11 & 12 & 0.90 & 0.02 & 12 & 24.2 & 1.81 \\
\hline & 09MAY1994 & 10 & 113.4 & 2.90 & 9 & 13.4 & 0.92 & 9 & 0.86 & 0.01 & 10 & 24.9 & 2.08 \\
\hline & 10MAY1994 & 10 & 118.4 & 1.92 & 9 & 14.5 & 0.75 & 9 & 0.87 & 0.02 & 10 & 35.7 & 2.89 \\
\hline & 11 MAY1994 & 10 & 115.0 & 1.11 & 10 & 14.2 & 0.51 & 10 & 0.93 & 0.01 & 10 & 25.3 & 2.52 \\
\hline & 12MAY1994 & 11 & 108.0 & 2.86 & 11 & 11.6 & 0.90 & 11 & 0.90 & 0.02 & 11 & 25.7 & 2.38 \\
\hline & 16MAY1994 & 10 & 116.1 & 3.59 & 10 & 14.8 & 1.41 & 10 & 0.91 & 0.02 & 10 & 35.8 & 0.82 \\
\hline & 17MAY1994 & 10 & 116.6 & 1.36 & 10 & 15.0 & 0.48 & 10 & 0.95 & 0.01 & 10 & 26.7 & 2.63 \\
\hline & 18MAY1994 & 10 & 119.7 & 1.49 & 10 & 15.5 & 0.59 & 10 & 0.90 & 0.01 & 10 & 28.7 & 1.13 \\
\hline & 23MAY1994 & 10 & 116.9 & 2.01 & 10 & 14.8 & 0.73 & 10 & 0.92 & 0.01 & 10 & 25.0 & 1.55 \\
\hline & 24MAY1994 & 10 & 119.6 & 2.36 & 10 & 16.3 & 1.17 & 10 & 0.94 & 0.02 & 9 & 27.2 & 2.00 \\
\hline & 25MAY1994 & 10 & 117.6 & 2.53 & 10 & 17.0 & 1.33 & 10 & 1.03 & 0.03 & 10 & 19.6 & 2.23 \\
\hline & 26MAY1994 & 10 & 119.1 & 1.35 & 10 & 17.0 & 0.64 & 10 & 1.00 & 0.02 & 10 & 24.4 & 1.87 \\
\hline
\end{tabular}


Appendix O1. Treatment, number, mean, and standard error of plasma lysozyme concentrations of coho salmon from Willard National Fish Hatchery, 1993.

\begin{tabular}{|c|c|c|c|}
\hline Treatment & $\underline{N}$ & $\begin{array}{r}\frac{\text { Mean Plasma }}{\text { Lysozyme }} \\
\mu \mathrm{g} \mathrm{\textrm {mL } ^ { - 1 } \mathrm { HEWL }}\end{array}$ & $\frac{\text { Standard }}{\text { Error }}$ \\
\hline Control & $\begin{array}{l}15 \\
12\end{array}$ & $\begin{array}{l}7.3 \\
6.1\end{array}$ & $\begin{array}{l}0.6 \\
1.0\end{array}$ \\
\hline Cover & $\begin{array}{c}8 \\
10\end{array}$ & $\begin{array}{l}7.2 \\
7.6\end{array}$ & $\begin{array}{l}0.9 \\
1.3\end{array}$ \\
\hline
\end{tabular}

Appendix O2. Treatment, number, mean, and standard error of mouth mucus lysozyme concentrations of coho salmon from Willard National Fish Hatchery and spring chinook salmon at Little White Salmon National Fish Hatchery, 1994.

\begin{tabular}{|c|c|c|c|}
\hline$\underline{\text { Treatment }}$ & $\underline{\mathrm{N}}$ & $\begin{array}{l}\frac{\text { Mean Mucus }}{\text { Lysozyme }} \\
\mu \mathrm{g} \mathrm{mL}^{-1} \mathrm{HEWL}\end{array}$ & $\frac{\text { Standard }}{\underline{\text { Error }}}$ \\
\hline \multicolumn{4}{|l|}{ WNFH } \\
\hline Control & 18 & 80 & 13 \\
\hline Cover & 15 & 94 & 11 \\
\hline \multicolumn{4}{|l|}{ LWSNFH } \\
\hline Control & 15 & 103 & 12 \\
\hline Cover & 13 & 110 & 14 \\
\hline
\end{tabular}


Appendix O3. Treatment, sample date, number, mean, and standard error of skin mucus lysozyme concentrations of coho salmon, Willard National Fish Hatchery, 1994.

$\begin{array}{llll}\text { Treatment } & \frac{\text { Sample }}{\text { Date }} & \begin{array}{c}\text { Lysozyme } \\ \text { Concentration }\end{array} & \underline{\text { Standard }} \\ & \underline{\underline{\mu \mathrm{mL}^{-1} \mathrm{HEWL}}} & \underline{\text { Error }}\end{array}$

\begin{tabular}{lllll} 
Control & $2 / 2 / 94$ & 30 & 62 & 5 \\
Cover & $2 / 2 / 94$ & 30 & 70 & 4 \\
Control & $3 / 3 / 94$ & 30 & 32 & 3 \\
Cover & $3 / 3 / 94$ & 29 & 29 & 3 \\
Control & $3 / 24 / 94$ & 30 & 22 & 6 \\
Cover & $3 / 24 / 94$ & 29 & 14 & 4 \\
Control & $4 / 18 / 94$ & & & 5 \\
Cover & $4 / 18 / 94$ & 29 & 29 & 3 \\
& & 29 & 24 & \\
\hline
\end{tabular}


Appendix O4. Treatment, sample date, number, mean, and standard error of nare mucus lysozyme concentrations of coho salmon, Willard National Fish Hatchery, 1994.

\begin{tabular}{|c|c|c|c|c|}
\hline$\underline{\text { Treatment }}$ & $\frac{\text { Sample }}{\text { Date }}$ & $\underline{\mathrm{N}}$ & $\begin{array}{c}\underline{\text { Lysozyme }} \\
\text { Concentration } \\
\mu \mathrm{g} \mathrm{\textrm {mL } ^ { - 1 } \mathrm { HEWL }}\end{array}$ & $\frac{\text { Standard }}{\underline{\text { Error }}}$ \\
\hline Control & $12 / 21 / 93$ & 9 & 364 & 60 \\
\hline Control & $2 / 2 / 94$ & 29 & 616 & 33 \\
\hline Cover & $2 / 2 / 94$ & 30 & 553 & 37 \\
\hline Control & $3 / 3 / 94$ & 29 & 404 & 30 \\
\hline Cover & $3 / 3 / 94$ & 30 & 437 & 23 \\
\hline Control & $3 / 24 / 94$ & 18 & 372 & 35 \\
\hline Cover & $3 / 24 / 94$ & 19 & 371 & 38 \\
\hline Control & $4 / 18 / 94$ & 26 & 324 & 23 \\
\hline Cover & $4 / 18 / 94$ & 30 & 337 & 24 \\
\hline
\end{tabular}


Appendix O5. Treatment, sample date, number, mean, and standard error of vent mucus lysozyme concentrations of coho salmon, Willard National Fish Hatchery, 1994.

\begin{tabular}{|c|c|c|c|c|}
\hline$\underline{\text { Treatment }}$ & $\frac{\text { Sample }}{\text { Date }}$ & $\underline{N}$ & $\begin{array}{c}\text { Lysozyme } \\
\text { Concentration } \\
\underline{\mu \mathrm{g} \mathrm{mL} \mathrm{mLWL}^{-1} \mathrm{HEWL}}\end{array}$ & $\frac{\text { Standard }}{\underline{\text { Error }}}$ \\
\hline Control & $12 / 21 / 93$ & 16 & 327 & 57 \\
\hline Cover & $12 / 21 / 93$ & 15 & 312 & 42 \\
\hline Control & $2 / 2 / 94$ & 30 & 284 & 26 \\
\hline Cover & $2 / 2 / 94$ & 29 & 204 & 18 \\
\hline Control & $3 / 3 / 94$ & 28 & 223 & 30 \\
\hline Cover & $3 / 3 / 94$ & 28 & 203 & 22 \\
\hline Control & $3 / 24 / 94$ & 30 & 120 & 9 \\
\hline Cover & $3 / 24 / 94$ & 29 & 163 & 17 \\
\hline Control & $4 / 18 / 94$ & 28 & 147 & 17 \\
\hline Cover & $4 / 18 / 94$ & 30 & 154 & 15 \\
\hline
\end{tabular}


Appendix O6. Treatment, sample date, number, mean, and standard error of skin mucus lysozyme concentrations of spring chinook salmon, Little White Salmon National Fish Hatchery, 1994.

\begin{tabular}{|c|c|c|c|c|}
\hline$\underline{\text { Treatment }}$ & $\frac{\text { Sample }}{\text { Date }}$ & $\underline{N}$ & $\begin{array}{c}\text { Lysozyme } \\
\text { Concentration } \\
\mu \mathrm{g} \mathrm{\textrm {mL } ^ { - 1 } \mathrm { HEWL }}\end{array}$ & $\frac{\text { Standard }}{\underline{\text { Error }}}$ \\
\hline Control & $12 / 21 / 93$ & 15 & 51 & 3 \\
\hline Cover & $12 / 21 / 93$ & 14 & 42 & 7 \\
\hline Control & $2 / 2 / 94$ & 30 & 162 & 74 \\
\hline Cover & $2 / 2 / 94$ & 30 & 92 & 3 \\
\hline Control & $3 / 3 / 94$ & 29 & 23 & 3 \\
\hline Cover & $3 / 3 / 94$ & 29 & 18 & 3 \\
\hline Control & $3 / 24 / 94$ & 30 & 33 & 5 \\
\hline Cover & $3 / 24 / 94$ & 30 & 30 & 3 \\
\hline Control & $4 / 18 / 94$ & 30 & 29 & 4 \\
\hline Cover & 4/18/94 & 29 & 28 & 5 \\
\hline
\end{tabular}


Appendix 07. Treatment, sample date, number, mean, and standard error of nare mucus lysozyme concentrations of spring chinook salmon, Little White Salmon National Fish Hatchery, 1994.

\begin{tabular}{|c|c|c|c|c|}
\hline Treatment & $\frac{\text { Sample }}{\text { Date }}$ & $\underline{N}$ & $\begin{array}{c}\text { Lysozyme } \\
\text { Concentration } \\
\underline{\mu \mathrm{g} \mathrm{mL} \mathrm{mLWL}^{-1} \mathrm{HEWL}}\end{array}$ & $\frac{\text { Standard }}{\underline{\text { Error }}}$ \\
\hline Control & $2 / 2 / 94$ & 30 & 739 & 60.8 \\
\hline Cover & $2 / 2 / 94$ & 30 & 712 & 67.1 \\
\hline Control & $3 / 3 / 94$ & 30 & 652 & 52.1 \\
\hline Cover & $3 / 3 / 94$ & 30 & 516 & 45.6 \\
\hline Control & $3 / 24 / 94$ & 29 & 379 & 33.0 \\
\hline Cover & $3 / 24 / 94$ & 30 & 394 & 37.2 \\
\hline Control & $4 / 18 / 94$ & 29 & 291 & 32.5 \\
\hline Cover & $4 / 18 / 94$ & 30 & 347 & 34.3 \\
\hline
\end{tabular}


Appendix O8. Treatment, sample date number, mean, and standard error of vent mucus lysozyme concentrations of spring chinook salmon, Little White Salmon National Fish Hatchery, 1994.

\begin{tabular}{|c|c|c|c|c|}
\hline$\underline{\text { Treatment }}$ & $\frac{\text { Sample }}{\text { Date }}$ & $\underline{\mathrm{N}}$ & $\begin{array}{c}\text { Lysozyme } \\
\text { Concentration } \\
\underline{\mu \mathrm{g} \mathrm{mL} \mathrm{mLWL}^{-1} \mathrm{HEWL}}\end{array}$ & $\frac{\text { Standard }}{\underline{\text { Error }}}$ \\
\hline Control & $12 / 21 / 93$ & 15 & 278 & 31 \\
\hline Cover & $12 / 21 / 93$ & 13 & 310 & 18 \\
\hline Control & $2 / 2 / 94$ & 30 & 280 & 26 \\
\hline Cover & $2 / 2 / 94$ & 30 & 293 & 30 \\
\hline Control & $3 / 3 / 94$ & 29 & 265 & 85 \\
\hline Cover & $3 / 3 / 94$ & 29 & 229 & 18 \\
\hline Control & $3 / 24 / 94$ & 30 & 229 & 21 \\
\hline Cover & $3 / 24 / 94$ & 30 & 170 & 17 \\
\hline Control & $4 / 18 / 94$ & 28 & 150 & 13 \\
\hline Cover & 4/18/94 & 30 & 176 & 15 \\
\hline
\end{tabular}


Appendix 09. Treatment, sample date, number, mean and standard error of plasma lysozyme from spring chinook salmon challenged with Renibacterium salmoninarum in 1993.

\begin{tabular}{|c|c|c|c|c|}
\hline Treatment & $\frac{\text { Sample }}{\text { Date }}$ & $\underline{\mathrm{N}}$ & $\begin{array}{c}\frac{\text { Lysozyme }}{\text { Concentration }} \\
\mu \mathrm{g} \mathrm{\textrm {mL } ^ { - 1 } \mathrm { HEWL }}\end{array}$ & $\frac{\text { Standard }}{\underline{\text { Error }}}$ \\
\hline Control & $10 / 5 / 93$ & 20 & 19.9 & 0.43 \\
\hline Challenged & $10 / 5 / 93$ & 20 & 19.5 & 0.83 \\
\hline Control & $10 / 26 / 93$ & 20 & 7.4 & 0.76 \\
\hline Challenged & $10 / 26 / 93$ & 20 & 2.3 & 0.14 \\
\hline Control & $11 / 16 / 93$ & 20 & 24.5 & 0.54 \\
\hline Challenged & $11 / 16 / 93$ & 20 & 24.5 & 0.84 \\
\hline Control & $12 / 9 / 93$ & 11 & 21.6 & 2.21 \\
\hline Challenged & $12 / 9 / 93$ & 9 & 26.2 & 0.62 \\
\hline
\end{tabular}


Appendix O10. Treatment, sample date, number, mean and standard error of skin mucus lysozyme from spring chinook salmon challenged with Renibacterium salmoninarum in 1993.

\begin{tabular}{lcccc}
\hline \multicolumn{1}{c}{ Treatment } & $\underline{\text { Sample }}$ & $\underline{\mathrm{N}}$ & $\begin{array}{c}\text { Lysozyme } \\
\text { Concentration } \\
\underline{\underline{\mathrm{g} \mathrm{mL}} \mathrm{mLWL}^{-1} \mathrm{HEWL}}\end{array}$ & $\underline{\underline{\text { Standard }}}$ \\
\hline Control & $7 / 1 / 93$ & 10 & 1017 & 42 \\
Challenged & $7 / 1 / 93$ & 13 & 716 & 104 \\
Control & $10 / 5 / 93$ & 19 & 132 & 20 \\
Challenged & $10 / 5 / 93$ & 20 & 254 & 46 \\
Control & $10 / 26 / 93$ & 20 & 545 & 61 \\
Challenged & $10 / 26 / 93$ & 20 & 140 & 32 \\
Control & $11 / 16 / 93$ & 20 & 51 & 7 \\
Challenged & $11 / 16 / 93$ & 20 & 35 & 6 \\
Control & $12 / 21 / 93$ & 11 & 770 & 68 \\
Challenged & $12 / 21 / 93$ & 9 & 1520 & 164 \\
\hline
\end{tabular}


Appendix O11. Treatment, sample date, number, mean and standard error of vent mucus lysozyme from spring chinook salmon challenged with Renibacterium salmoninarum in 1993.

\begin{tabular}{|c|c|c|c|c|}
\hline$\underline{\text { Treatment }}$ & $\frac{\text { Sample }}{\underline{\text { Date }}}$ & $\underline{\mathrm{N}}$ & $\begin{array}{c}\begin{array}{c}\text { Lysozyme } \\
\text { Concentration }\end{array} \\
\underline{\mu \mathrm{g} \mathrm{mL}^{-1} \mathrm{HEWL}}\end{array}$ & $\frac{\underline{\text { Standard }}}{\underline{\text { Error }}}$ \\
\hline Control & $6 / 10 / 93$ & 20 & 431 & 82 \\
\hline Challenged & $6 / 10 / 93$ & 20 & 1473 & 102 \\
\hline Control & 7/1/93 & 6 & 1187 & 67 \\
\hline Challenged & 7/1/93 & 3 & 1038 & 138 \\
\hline Control & $10 / 5 / 93$ & 20 & 775 & 57 \\
\hline Challenged & $10 / 5 / 93$ & 19 & 1023 & 94 \\
\hline Control & $10 / 26 / 93$ & 20 & 413 & 39 \\
\hline Challenged & $10 / 26 / 93$ & 20 & 390 & 85 \\
\hline Control & $11 / 16 / 93$ & 20 & 217 & 24 \\
\hline Challenged & $11 / 16 / 93$ & 20 & 295 & 44 \\
\hline Control & $12 / 21 / 93$ & 11 & 241 & 60 \\
\hline Challenged & $12 / 21 / 93$ & 9 & 258 & 46 \\
\hline
\end{tabular}


Appendix 012. Treatment, sample date, number, mean and standard error of skin mucus lysozyme from spring chinook salmon challenged with Renibacterium salmoninarum in 1994.

\begin{tabular}{|c|c|c|c|c|}
\hline$\underline{\text { Treatment }}$ & $\frac{\text { Sample }}{\text { Date }}$ & $\underline{N}$ & $\begin{array}{c}\text { Lysozyme } \\
\text { Concentration } \\
\mu \mathrm{g} \mathrm{\textrm {mL } ^ { - 1 } \mathrm { HEWL }}\end{array}$ & $\frac{\text { Standard }}{\underline{\text { Error }}}$ \\
\hline Control & $5 / 31 / 94$ & 20 & 13 & 3 \\
\hline Challenged & $5 / 31 / 94$ & 20 & 21 & 4 \\
\hline Control & $6 / 15 / 94$ & 20 & 16 & 4 \\
\hline Challenged & $6 / 15 / 94$ & 19 & 15 & 4 \\
\hline Control & $6 / 29 / 94$ & 19 & 44 & 4 \\
\hline Challenged & $6 / 29 / 94$ & 19 & 42 & 2 \\
\hline Control & $7 / 11 / 94$ & 16 & 22 & 6 \\
\hline Challenged & $7 / 11 / 94$ & 19 & 31 & 12 \\
\hline Control & $7 / 28 / 94$ & 19 & 53 & 4 \\
\hline Challenged & $7 / 28 / 94$ & 20 & 68 & 7 \\
\hline Control & $8 / 11 / 94$ & 13 & 56 & 3 \\
\hline Challenged & $8 / 11 / 94$ & 19 & 168 & 28 \\
\hline Control & $8 / 25 / 94$ & 20 & 138 & 28 \\
\hline Challenged & $8 / 25 / 94$ & 18 & 115 & 25 \\
\hline
\end{tabular}


Appendix O13. Treatment, sample date, number, mean and standard error of nare mucus lysozyme from spring chinook salmon challenged with Renibacterium salmoninarum in 1994.

\begin{tabular}{|c|c|c|c|c|}
\hline$\underline{\text { Treatment }}$ & $\frac{\text { Sample }}{\underline{\text { Date }}}$ & $\underline{\mathrm{N}}$ & $\begin{array}{c}\begin{array}{c}\text { Lysozyme } \\
\text { Concentration }\end{array} \\
\mu \mathrm{g} \mathrm{\textrm {mL } ^ { - 1 } \mathrm { HEWL }} \\
\end{array}$ & $\frac{\frac{\text { Standard }}{\text { Error }}}{\text { then }}$ \\
\hline Control & $5 / 31 / 94$ & 20 & 566 & 35 \\
\hline Challenged & $5 / 31 / 94$ & 20 & 558 & 34 \\
\hline Control & 6/15/94 & 20 & 572 & 47 \\
\hline Challenged & $6 / 15 / 94$ & 20 & 481 & 40 \\
\hline Control & $6 / 29 / 94$ & 19 & 567 & 44 \\
\hline Challenged & 6/29/94 & 18 & 575 & 34 \\
\hline Control & 7/11/94 & 16 & 459 & 53 \\
\hline Challenged & 7/11/94 & 20 & 496 & 52 \\
\hline Control & $7 / 28 / 94$ & 18 & 428 & 36 \\
\hline Challenged & $7 / 28 / 94$ & 18 & 601 & 35 \\
\hline Control & $8 / 11 / 94$ & 13 & 265 & 33 \\
\hline Challenged & $8 / 11 / 94$ & 20 & 601 & 46 \\
\hline Control & $8 / 25 / 94$ & 20 & 494 & 65 \\
\hline Challenged & $8 / 25 / 94$ & 20 & 511 & 53 \\
\hline
\end{tabular}


Appendix O14. Treatment, sample date, number, mean and standard error of vent mucus lysozyme from spring chinook salmon challenged with Renibacterium salmoninarum in 1994.

\begin{tabular}{|c|c|c|c|c|}
\hline Treatment & $\frac{\text { Sample }}{\underline{\text { Date }}}$ & $\underline{\mathrm{N}}$ & 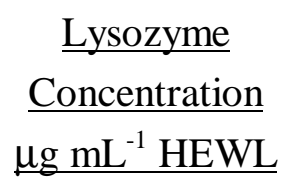 & $\frac{\underline{\text { Standard }}}{\text { Error }}$ \\
\hline Control & $5 / 31 / 94$ & 20 & 143 & 13 \\
\hline Challenged & $5 / 31 / 94$ & 20 & 168 & 20 \\
\hline Control & $6 / 15 / 94$ & 20 & 153 & 20 \\
\hline Challenged & $6 / 15 / 94$ & 20 & 159 & 23 \\
\hline Control & 6/29/94 & 20 & 189 & 20 \\
\hline Challenged & 6/29/94 & 20 & 164 & 24 \\
\hline Control & 7/11/94 & 16 & 362 & 49 \\
\hline Challenged & 7/11/94 & 19 & 340 & 46 \\
\hline Control & $7 / 28 / 94$ & 14 & 244 & 37 \\
\hline Challenged & $7 / 28 / 94$ & 7 & 410 & 65 \\
\hline Control & $8 / 11 / 94$ & 13 & 263 & 47 \\
\hline Challenged & $8 / 11 / 94$ & 20 & 440 & 54 \\
\hline Control & $8 / 25 / 94$ & 20 & 359 & 55 \\
\hline Challenged & $8 / 25 / 94$ & 20 & 393 & 44 \\
\hline
\end{tabular}




\section{Appendix O15. Hatchery survey of rearing conditions for the Smolt Monitoring Program}

hatcheries, 1994.

\begin{tabular}{|c|c|c|c|c|c|c|}
\hline Hatchery & Antibiotics & $\begin{array}{c}\text { Chemical } \\
\text { Bath }\end{array}$ & $\begin{array}{c}\text { Disease } \\
\text { Episodes }\end{array}$ & Diet & $\begin{array}{l}\text { Water } \\
\text { Source }\end{array}$ & $\begin{array}{l}\text { Water } \\
\text { Temp. }\end{array}$ \\
\hline Dworshak & $\begin{array}{l}\text { Erythromycin } \\
2 \mathrm{X} 21 \text { days } \\
4 / 93,9 / 93 \\
100 \mathrm{mg} / \mathrm{kg} / \mathrm{d}\end{array}$ & None & & None & $\begin{array}{c}\text { Reservoir } \\
\text { (river), River } \\
\text { water }(\sim 1 \text { year) }\end{array}$ & $40-54^{\circ} \mathrm{F}$ \\
\hline McCall & & & & & $\begin{array}{l}\text { River } \\
\text { water }\end{array}$ & $38-52^{\circ} \mathrm{F}$ \\
\hline Rapid River & $\begin{array}{c}\text { Erythromycin 4/93, } \\
7 / 93 \\
\text { TM-50 } \\
5 / 93,6 / 93,8 / 93\end{array}$ & none & $\begin{array}{c}\text { fungus } 8 / 93 \\
\text { peak } \\
\text { mortality } \\
10 / 93\end{array}$ & $\begin{array}{l}\text { Biodiet- early } \\
\quad \text { rearing } \\
\text { Biomoist with } \\
\text { EIBS vitamin } \\
\quad \text { pack }\end{array}$ & $\begin{array}{l}\text { River } \\
\text { water }\end{array}$ & $36-60^{\circ} \mathrm{F}$ \\
\hline Ringold & $\begin{array}{c}\text { Gallimycin } \\
\text { Aquamycin } \\
\text { TM } 100\end{array}$ & Formalin & Entero-cytozoan & $\begin{array}{c}\text { Biodiet Starter } \\
\text { BioDry } \\
\text { Biomoist } \\
\text { Grower }\end{array}$ & & $58-60^{\circ} \mathrm{F}$ \\
\hline Entiat & $\begin{array}{c}\text { Erythromycin } \\
21 \text { days } \\
2 / 94,3 / 94\end{array}$ & $\begin{array}{c}\text { Formalin } \\
3 / 93\end{array}$ & BKD 12/93 & $\begin{array}{c}\text { Biomoist } \\
\text { Starter } \\
\text { Grower } \\
\text { Medicated } 4.5 \% \\
\text { Aquamycin }\end{array}$ & $\begin{array}{c}\text { Spring- } \\
\text { water } \\
\text { to } 12 / 93 \text {, mixed with } \\
\text { surface water }\end{array}$ & $36-50^{\circ} \mathrm{F}$ \\
\hline
\end{tabular}

